\title{
Riikka Heikkilä
}

\section{Rapid automatized naming and reading fluency in children with learning difficulties}
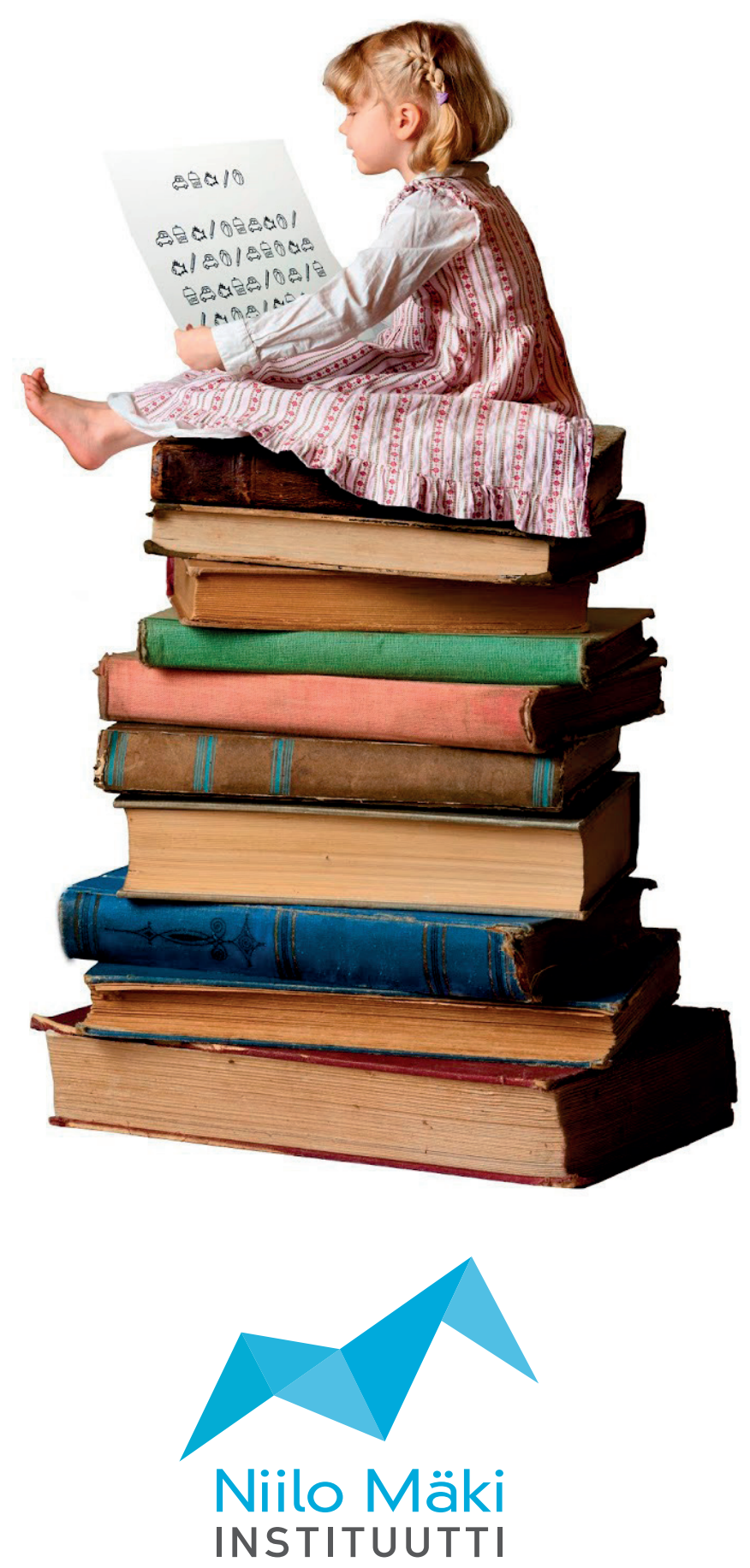


\section{Riikka Heikkilä}

\section{Rapid Automatized Naming and Reading Fluency in Children with Learning Difficulties}

Esitetään Jyväskylän yliopiston kasvatustieteiden tiedekunnan suostumuksella julkisesti tarkastettavaksi yliopiston Agora-rakennuksen Gamma-salissa toukokuun 22. päivänä 2015 kello 12.

Academic dissertation to be publicly discussed, by permission of the Faculty of Education of the University of Jyväskylä,

in building Agora, auditorium Gamma, on May 22, 2015 at 12 o'clock noon.

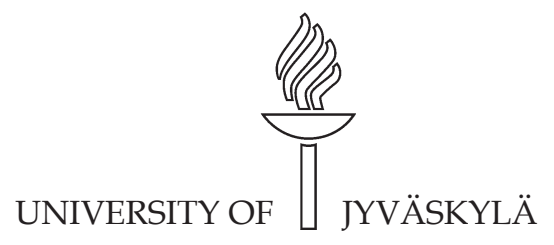

JYVÄSKYLÄ 2015 


\section{Rapid Automatized Naming and Reading Fluency in Children with Learning Difficulties}


JYVÄSKYLÄ STUDIES IN EDUCATION, PSYCHOLOGY AND SOCIAL RESEARCH 523

\section{Riikka Heikkilä}

\section{Rapid Automatized Naming and Reading Fluency in Children with Learning Difficulties}

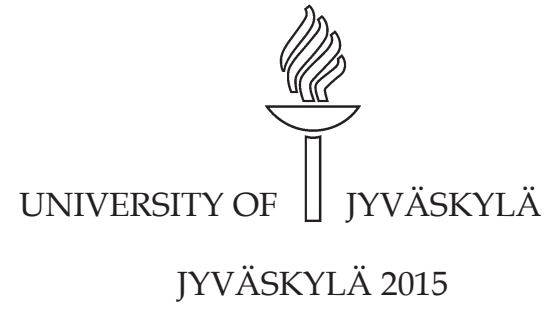




\section{Editors}

Timo Suutama

Department of Psychology, University of Jyväskylä

Pekka Olsbo, Timo Hautala

Publishing Unit, University Library of Jyväskylä

URN:ISBN:978-951-39-6188-6

ISBN 978-951-39-6188-6 (PDF)

ISBN 978-951-39-6187-9 (nid.)

ISSN 0075-4625

Copyright @ $@ 2015$, by University of Jyväskylä

Jyväskylä University Printing House, Jyväskylä 2015 


\author{
ABSTRACT \\ Heikkilä, Riikka \\ Rapid automatized naming and reading fluency in children with learning \\ difficulties \\ Jyväskylä: University of Jyväskylä, 2015, 82 p. \\ (Jyväskylä Studies in Education, Psychology and Social Research \\ ISSN 0075-4625; 523) \\ ISBN 978-951-39-6187-9 (nid.) \\ ISBN 978-951-39-6188-6 (PDF)
}

This research evaluated the ability to retrieve and fluently name serially presented familiar items, known as rapid automatized naming (RAN), as an underlying skill in reading disability and its role in a reading fluency intervention. The specificity of RAN on reading was examined in two studies among children with learning difficulties. These two studies showed that RAN was most strongly related to reading disabilities (RD), and less clearly related to math or attention deficits. This was especially true when RD was defined as reading speed or fluency. The association between RAN and RD was also examined within the framework of the double-deficit hypothesis (DDH), in which RAN is assumed to contribute independently to RD along with phonological awareness. The results among children with learning difficulties supported the DDH in that RAN was not related to phonological awareness but had a unique connection with reading fluency and speed. Children with double-deficit performed poorer in reading and spelling skills compared to the groups with a single deficit or controls. The reading fluency intervention, conducted among children with poor reading skill, showed significant effects on the repeated recognition of sublexical units (syllables). Moreover, a wordlevel transfer effect, which was also the strongest syllable-level intervention effect, was found for infrequent syllables. Reading fluency gains were greatest for the children with the lowest pre-intervention reading skills. The results showed that although RAN was associated with initial reading speed, it did not have an effect on the intervention gains. These studies strengthen the role of RAN as an independent skill underlying reading disabilities in a transparent language (Finnish) where reading disabilities are most strongly manifested as dysfluent reading. While comorbid learning problems were common and should be acknowledged in the assessment and intervention of reading, the slow naming speed found here indicated deficits specific to reading fluency. Despite the persistent nature of naming and reading fluency deficits, reading fluency does not seem to be resistant to intervention even when accompanied with naming speed deficits.

Keywords: rapid automatized naming, reading disabilities, reading fluency, reading speed, learning disability, comorbidity, reading intervention 
Riikka Heikkilä

Niilo Mäki Institute

P. O. BOX 35

FIN-40014 University of Jyväskylä

Email: riikka.heikkila@nmi.fi

Supervisors

Professor Timo Ahonen (main supervisor)

Department of Psychology

University of Jyväskylä, Finland

Professor Mikko Aro

Department of Education

University of Jyväskylä, Finland

Vesa Närhi (PhD)

Niilo Mäki Institute, Jyväskylä, Finland and

School of Educational Sciences and Psychology

University of Eastern Finland, Joensuu, Finland

Reviewers

Docent (emeritus) Tapio Korhonen

Department of Behavioural Sciences and Philosophy

University of Turku, Finland

Associate Professor George Georgiou

Department of Educational Psychology

University of Alberta, Canada

Opponent

Associate Professor George Georgiou

Department of Educational Psychology

University of Alberta, Canada 


\title{
TIIVISTELMÄ (FINNISH ABSTRACT)
}

\author{
Heikkilä, Riikka
}

Nopea nimeäminen ja lukemisen sujuvuus oppimisvaikeuslapsilla.

Jyväskylä: Jyväskylän yliopisto, 2015, 82 p.

(Jyväskylä Studies in Education, Psychology and Social Research

ISSN 0075-4625; 523)

ISBN 978-951-39-6187-9 (nid.)

ISBN 978-951-39-6188-6 (PDF)

Tämän tutkimuksen keskiössä olivat lukemisen sujuvuus sekä nopea sarjallinen nimeäminen (rapid automatized naming, RAN), kyky hakea mielestä ja nimetä sujuvasti sarjallisessa muodossa esitettyjä tuttuja nimikkeitä. Tässä tutkimuksessa arvioitiin erityisesti RAN:n roolia lukemisvaikeuksien taustataitona sekä sen yhteyttä lukemisen sujuvuuden kuntouttamiseen. RAN:n spesifiä yhteyttä lukemiseen tutkittiin kahdessa osatutkimuksessa, joiden kohderyhmänä olivat kouluikäiset oppimisvaikeuksiset lapset. Tulokset osoittivat, että RAN oli matematiikan ja tarkkavuuden ongelmia vahvemmin yhteydessä lukemisvaikeuksiin, erityisesti kun lukemisvaikeus oli määritelty lukemisen nopeuden tai sujuvuuden perusteella. RAN:n ja lukemisvaikeuden yhteyttä tutkittiin myös kaksoisvaikeushypoteesin (double-deficit hypothesis, DDH) näkökulmasta, joka olettaa RAN:n vaikuttavan fonologisesta tietoisuudesta erillisenä taustataitona lukemisvaikeuksiin. Tulokset oppimisvaikeuslapsilla tukivat DDH:ta siten, että RAN ei ollut yhteydessä fonologiseen tietoisuuteen mutta oli spesifisti yhteydessä lukemisen nopeuteen ja sujuvuuteen. Lapset, joilla oli kaksoisvaikeus, lukivat ja kirjoittivat kaikkia muita ryhmiä heikommin. Kolmannessa osatutkimuksessa heikoilla lukijoilla toteutettu lukemisen sujuvuuden interventio tuotti merkitseviä tuloksia sanaa pienempien yksiköiden (tavujen) lukemisen nopeudessa. Tämä vaikutus näkyi myös sanatasolla pitkissä harvinaisissa tavuissa, joissa harjoittelun vaikutus oli suurin. Lukijat, joiden lukemisen taso ennen harjoittelun alkua oli heikoin, edistyivät eniten. RAN oli yhteydessä lukemisen alkutasoon, muttei edistymiseen harjoittelun aikana. Nämä tutkimukset vahvistavat RAN:n roolia lukemisen taustataitona kirjoitusjärjestelmältään säännönmukaisessa kielessä (suomi), jossa lukemisvaikeudet esiintyvät erityisesti lukemisen hitautena. Vaikka oppimisen haasteet esiintyvät usein yhdessä ja vaikka tämä komorbiditeetti pitäisi huomioida lukemisen arvioinnissa ja kuntoutuksessa, nimeämisen hitaus ei tämän tutkimuksen perusteella näytä olevan yhteydessä oppimisvaikeuksien päällekkäistymiseen vaan erityisesti lukemisen sujuvuuteen. Vaikka nimeämisen ja lukemisen hitauden tiedetään olevan sitkeitä ongelmia, lukemisen sujuvuutta ei näytä olevan kuitenkaan mahdotonta kuntouttaa edes silloin, kun siihen liittyy nimeämisen hitautta.

Avainsanat: nopea sarjallinen nimeäminen, lukemisvaikeudet, lukemisen sujuvuus, lukunopeus, oppimisvaikeus, komorbiditeetti, lukemisen kuntouttaminen 


\section{ACKNOWLEDGEMENTS}

There are number of people to whom I would like to express my gratitude. First of all, I have had the great privilege to have a highly supportive and wise group of supervisors to guide my way through the dissertation process. Professor Timo Ahonen has always had time to encourage me in many ways, and he has inspired me by sharing his ideas and visions also on future plans. I own my warmest thanks to Professor Mikko Aro for teaching and modelling me indepth scientific thinking. Mikko's critical scientific evaluation of research frames and research articles has taught me to understand the logic and reasoning of scientific writing. Doctor Vesa Närhi was already supervisor of my master's thesis, and his supportive attitude has boosted my morale countless times. I believe that without the encouragement, humor, and wisdom provided by this team my road towards this day would have been a lot rockier. I also want to thank Professor Heikki Lyytinen for providing me, unofficially, with guidance in the Nyrkki group and giving me many interesting opportunities in his research group. I also want to express my thanks to the reviewers of this thesis, Professor emeritus Tapio Korhonen and Associate Professor George Georgiou for their careful evaluation of the dissertation.

I have been very fortunate to be able to work in many communities that have all have provided me with so much warm guidance and support. To my colleagues and friends in the Niilo Mäki Institute, LukiMat project, GraphoGame project, Nekku, and JLD group I would like to express my gratitude for their encouragement and walking beside me throughout this process. Writing a dissertation is not always fun (and should not be) but a good laugh once in a while helps a lot in the process. Thank you for being a blessing to me. I want to express my special thanks to my co-authors of the individual papers, Minna Torppa and Jari Westerholm, and to Kenneth Eklund and Tuire Koponen for their help and insightful comments on the manuscripts.

I'm also grateful to the Child Research Clinic of the Niilo Mäki Institute for the provision of the data needed for two of the individual articles. I also want to thank the LukiMat team, research assistants, children, schools, and teachers all over the Finland who have participated in the data collection for the third article.

Finally, I want to give very special thanks to my family and friends for encouraging me not only in my scientific work but also in life in general. To Markku and Manna: Thank you for reminding me of the most important things in life. To our newborn family member, Maiju: Thank you for the boost in motivation you have given me to finish my dissertation. Most of all, I want give thanks to the One who holds all things together and has provided all the good things.

This research has been supported by the Finnish Graduate School of Psychology, the Ministry of Education and Culture, and Finland's Slot Machine association (RAY). In addition to the above, I want to thank the department of Psychology and Niilo Mäki Foundation for financial support for this thesis. 


\section{LIST OF ORIGINAL PUBLICATIONS}

I Heikkilä, R., Närhi, V., Aro, M, \& Ahonen, T. (2009). Rapid automatized naming and learning disabilities: Does RAN have a specific connection to reading or not? Child Neuropsychology, 15, 343-358.

II Heikkilä, R., Torppa, M., Aro, M., Närhi, V., \& Ahonen, T. (2015). Doubledeficit hypothesis in a clinical sample: extension beyond reading. Journal of Learning Disabilities. Advance online publication. doi:10.1177/0022219415572895

III Heikkilä, R., Aro, M, Närhi, V., Westerholm, J., \& Ahonen, T. (2013). Does training in syllable recognition improve reading speed? A computer-based trial with poor readers from second and third grade. Scientific Studies of Reading, 17, 398-414.

Description of the writer's contribution to the individual articles:

Taking into account the instructions given and comments made by the coauthors, the author of the thesis has been the first author of all three individual articles. She has had an active role in the study design, statistical analysis, data interpretation, manuscript preparation and literature research in all the individual articles. She coordinated the data collection in Study III and participated in the funding applications that have enabled the preparation and reporting of these studies. 


\title{
CONTENTS
}

\author{
ABSTRACT \\ TIIVISTELMÄ (FINNISH ABSTRACT) \\ ACKNOWLEDGEMENTS \\ LIST OF ORIGINAL PUBLICATIONS \\ CONTENTS
}

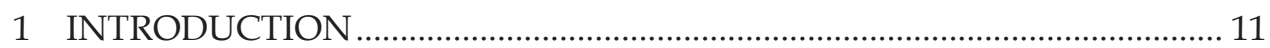

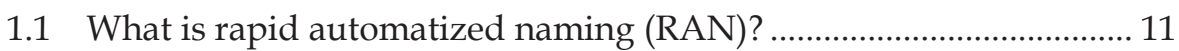

1.2 Is RAN specific to reading and reading disability? .............................. 14

1.3 How is RAN related to reading? ........................................................ 16

1.3.1 In a search of explanations for the RAN-reading relationship... 16

1.3.2 RAN as an independent predictor of reading disabilities: the double-deficit hypothesis ........................................................ 21

1.3.3 RAN and reading in orthographies varying in transparency ............................................................................... 23

1.3.4 RAN in a continuum of reading skills ...................................... 25

1.4 Reading fluency intervention ................................................................ 27

1.4.1 Reading fluency intervention in transparent orthographies .. 27

1.4.2 The effect of RAN in reading fluency intervention.................. 29

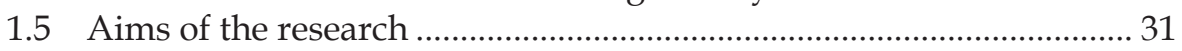

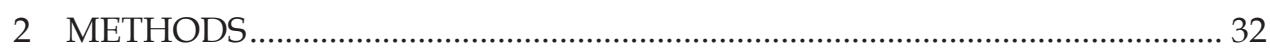

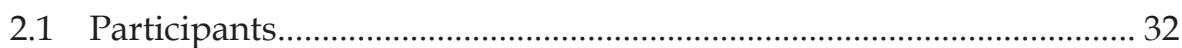

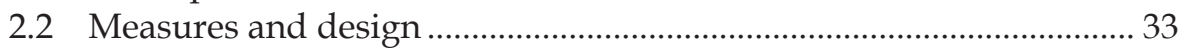

3 OVERVIEW OF THE ORIGINAL STUDIES.................................................... 35

3.1 Study 1: Rapid automatized naming and learning disabilities:

Does RAN have a specific connection to reading or not? .................... 35

3.2 Study 2: The double-deficit hypothesis in a clinical sample: extension beyond reading.

3.3 Study 3: Does training in syllable recognition improve reading speed? A computer-based trial with poor readers from second and

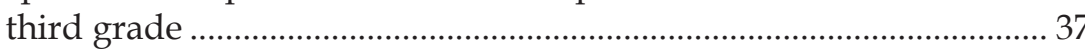

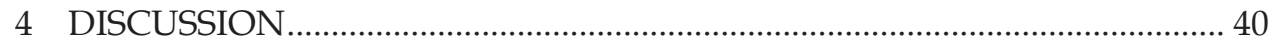

4.1 RAN in the field of academic difficulties and cognitive skills ........... 41

4.2 RAN and reading in a transparent orthography ................................... 45

4.3 On the reading intervention and RAN .................................................. 48

4.4 Limitations and suggestions for future research .................................. 52

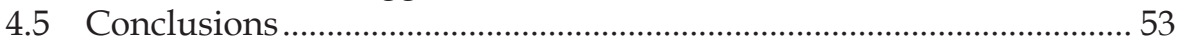

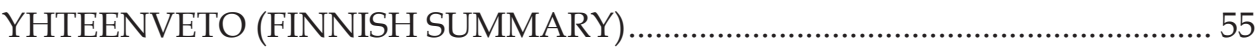

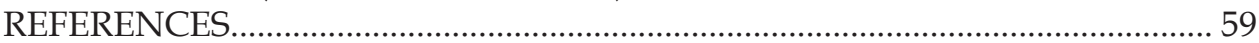




\section{INTRODUCTION}

\subsection{What is rapid automatized naming (RAN)?}

Rapid automatized naming (RAN), also referred to as rapid serial naming and naming speed, is usually defined as the skill to retrieve and fluently name serially presented familiar items such as objects, colors, letters or digits. Since the 1970s, when this construct was introduced by Denckla and Rudel (1976), RAN has most often been studied in relation to reading and reading disabilities. A connection between RAN and reading has, in fact, been verified in a number of studies (for reviews, see Denckla \& Cutting, 1999; Georgiou \& Parrila, 2013; Kirby, Georgiou, Martinussen, \& Parrila, 2010; Norton \& Wolf, 2012; Wolf \& Bowers 1999; Wolf, Bowers, \& Biddle, 2000). However, RAN has also been studied in relation to several other academic and cognitive skills, such as math performance, attention, processing speed, orthographic skills, phonological awareness, short-term memory, and automatization. The results of these studies have been contradictory (introduced later in more detail) and thus the question what RAN is continues to be a subject of debate.

Most commonly, it is suggested that RAN measures efficient visual-verbal access (e.g., Lervåg \& Hulme, 2009; Moll, Fussenegger, Willburger, \& Landerl, 2009) and the automatization or quality of these visual-verbal associations (Norton \& Wolf, 2012; Willburger, Fussenger, Moll, Wood, \& Landerl, 2008). Conversely, RAN has been described as a speed of lexical access that hampers the development of orthographic patterns (Bowers \& Wolf 1993). It has also been defined as a skill revealing the speed or automaticity of phonological access (e.g., Ramus, 2014; Torgesen, Wagner, Rashotte, Burgess, \& Hecht, 1997; Wagner et al., 1997) or lexical retrieval (Pennington, Cardoso-Martins, Green, \& Lefly, 2001). Many of these definitions are overlapping, and many of them refer to linguistic skills such as phonological processing or orthographic knowledge. If these definitions prove to be correct, the link between RAN and reading would be rather easy to understand. However, some suggestions have been made regarding links between RAN and more general cognitive skills that are 
not specifically linked with reading or linguistic skills. These alternatives suggest that RAN is a measure of general processing speed (Kail \& Hall, 1994; Kail, Hall, \& Caskey, 1999) or general automatization (Nicolson \& Fawcett, 1990). Thus, depending on the perspective, RAN can be seen as a linguistic skill related especially to reading, or a more general cognitive skill associated with a wide variety of other skills. Presumably, RAN reflects both of these perspectives to some extent. Denckla and Cutting (1999) suggested that RAN is associated with both visual-verbal (language domain) and processing speed (executive domain). Georgiou and Parrila (2013) ended up on similar lines, suggesting that the basic naming process requires sequential processing as well as processing speed, with alphanumeric RAN (introduced more thoroughly below) also reflecting linguistic skills such as phonological retrieval and orthographic representations (Georgiou \& Parrila, 2013).

While no clear consensus exists on what precisely constitutes RAN, it is generally agreed that many connected and partly overlapping processes affect naming speed. According to Wolf et al. (Wolf \& Bowers, 1999; Wolf et al., 2000), these processes in serial letter naming include 1) attentional processes (i.e., attention to the stimulus), 2) visual sub-processes responsible for the identification of the target, 3) integration of visual features with an orthographic representation, 4) integration of visual and orthographic information with a phonological representation, 5) access and retrieval of the phonological label, 6) activation and integration of semantic and conceptual information, and 7) the motoric activation needed for articulation of the item. Most of the sub-processes described above also include requirements for processing speed (Wolf \& Bowers, 1999, p. 418). The authors also noted that precise and rapid timing mechanisms are critical in the individual sub-processes and in their integration to make the whole process efficient. Other attentional processes, like inhibition, are also involved in serial processing, where previous and upcoming responses have to be suppressed while planning the current response (Arnell, Joanisse, Klein, Busseri, \& Tannock, 2009). Thus, as many researchers already concede, RAN is a multicomponential skill (Bowers \& Ishaik, 2003; Denckla \& Cutting, 1999; Georgiou \& Parrila, 2013; Närhi et al., 2005; Salmi, 2008; Wolf et al., 2000; Wolf \& Bowers, 1999). Consequently, to describe RAN as a measure of a single cognitive skill would call to mind the parable of blind men exploring an elephant: none of these single views can fully capture the nature of the process of rapid automatized naming.

Moreover, the different types of RAN tasks used in studies exploring the connection between RAN, reading, and other cognitive skills may differ in their cognitive requirements and therefore yield different results. Alphanumeric (numbers and letters), non-alphanumeric (colors and objects), and rapid alternating stimulus (RAS; Wolf, 1986), where alphanumeric and non-alphanumeric items are mixed, seem to form correlated but independent groups, differing in their cognitive requirements (Närhi et al., 2005). Before school age, children usually name non-alphanumeric stimuli faster than or as fast as alphanumeric stimuli. After school entry, alphanumeric stimuli are soon named faster than 
non-alphanumeric (Cronin \& Carver 1998; Nopola-Hemmi et al., 2002; Wolf et al., 1986), possibly because of increased exposure (Klein, 2002) or semantic priming (Reynvoet, Brysbaert, \& Fias, 2002). Another explanation refers to semantic uncertainty, which means that the name of the object or color is not as distinct as it is in the case of alphanumeric stimuli (Johnson, Paivio, \& Clark, 1996; Wolff, Michel, \& Ovrut, 1990c). According to several studies, alphanumeric stimuli are more closely related to decoding than non-alphanumeric stimuli, at least in school-aged children (for reviews, see Araújo, Reis, Petersson, \& Faísca, 2014; Georgiou \& Parrila, 2013; Kirby et al., 2010). Non-alphanumeric stimuli are, instead, suggested to relate more to general processing speed (Catts, Gillispie, Leonard, Kail, \& Miller, 2002), reading comprehension (Badian, 1993; Wolf, Bally, \& Morris, 1986), or attention and executive functions (e.g., SemrudClikeman, Guy, Griffin, \& Hynd, 2000; Stringer, Toplak, \& Stanovich, 2004). It is also proposed that naming non-alphanumeric stimuli requires more efficient perceptional and semantic processing than naming alphanumeric stimuli (e.g., Braisby \& Dockrell, 1999; Denckla \& Rudel, 1976; Moore \& Price, 1999). In addition, recent findings from functional imaging studies also refer to differential brain activation between alphanumeric and non-alphanumeric RAN tasks (Cummine, Szepesvari, Chouinard, Hanif, \& Georgiou, 2014). A third category of naming tasks, rapid alternating stimulus (RAS), is suggested to be even more multicomponential in nature than RAN tasks. Alternating stimuli within a naming task is thought to be more demanding on the attention and executive functions, cognitive flexibility, memory access, and semantic processing than RAN tasks (e.g., Albuquerque \& Simões, 2010; Altemeier, Abbott, \& Berninger, 2008; Semrud-Clikeman et al., 2000; Wiig et al., 2000; Wolf, 1986). In several studies alphanumeric RAN has been associated with reading while non-alphanumeric items have either not been linked with reading (Christopher et al., 2012; Stringer, Toplak, \& Stanovich, 2004) or the association has been considerably weaker (Poulsen, Juul, \& Elbro, 2015; Schatschneider, Fletcher, Francis, Carlson, \& Foorman, 2004). In this research, only alphanumeric RAN tasks were included in the studies, which probably strengthened the association between RAN and reading, and should be borne in mind when interpreting the results in comparison with studies using different types of RAN tasks.

Over and above the cognitive and behavioral factors associated with RAN, neurobiological components of this skill have also been explored. In longitudinal studies, naming speed has proven to be rather stable and naming speed deficits appear to be persistent in nature (e.g., Korhonen 1995; Landerl \& Wimmer, 2008; Mazzocco \& Grimm, 2013; Powell, Stainthorp, \& Stuart, 2014). Some part of this stability can be explained by genetic sources, as a strong genetic influence has been shown in RAN performance (e.g., Byrne et al., 2006; Christopher et al., 2015; Davis et al., 2001; Petrill, Deater-Deckard, Thompson, DeThorne, \& Schatschneider, 2006; Petrill et al., 2010; Samuelsson et al., 2007). There is also recent research evidence for specific genes that have been associated with RAN performance (Naples, Chang, Katz, \& Grigorenko, 2009), some of them the same as those previously associated with dyslexia (Rubenstein, Raskind, 
Berninger, Matsushita, \& Wijsman, 2014). In addition, brain imaging studies have recently shed further light on the neural basis of RAN performance, showing that activation during naming tasks is present in the areas involved in attention, and that eye-movement control is also present in the areas usually associated with reading tasks (McCrory, Mechelli, Frith, \& Price, 2005; Misra, Katzir, Wolf, \& Poldrack, 2004). In sum, RAN has attributes that most probably link it to several cognitive and academic skills, and hence as a multicomponential but yet easily measured skill RAN has claimed its place in research.

\subsection{Is RAN specific to reading and reading disability?}

Based on the first study conducted with this question in mind (Denckla \& Rudel, 1976) the answer would be affirmative. RAN differentiated the children with dyslexia not only from the control children but also from children with other learning difficulties. It was concluded that RAN was a specific predictor of reading disabilities. Since then, most of the research on RAN has been conducted in the field of dyslexia and reading research. This research has found evidence of linkages between RAN and various aspects of literacy, including reading accuracy (e.g., Compton, 2000; Cornwall, 1992; Cutting \& Denckla, 2001; Kirby, Parrila, \& Pfeiffer, 2003; Manis, Seidenberg, \& Doi, 1999; Schatschneider et al., 2004; Wolf, 1997, 1999), reading fluency (e.g., Bowers, 1995; Moll et al., 2009; Papadopoulos, Georgiou \& Kendeou, 2009; Torppa, Georgiou, Salmi, Eklund \& Lyytinen, 2012; Wimmer, Mayringer, \& Landerl, 2000; Young \& Bowers, 1995), and reading comprehension (Badian, 1993; Neuhaus, Foorman, Francis, \& Carlson, 2001; Papadopoulos et al., 2009; Schatschneider et al., 2004; Sprugevica \& Høien 2003, 2004), and also spelling (Georgiou, Torppa, Manolitsis, Lyytinen, \& Parrila, 2012; Savage et al., 2005; Savage, Pillay, \& Melidona, 2008; Torppa et al., 2012; Wimmer et al., 2000). However, the research evidence thus far has shown the strongest support for a connection between RAN and reading fluency (often defined as speed of accurate response to oral reading tasks) or reading speed, as the evidence on the connections with other aspects of reading or spelling have been more or less conflicting (for reviews, see Georgiou \& Parrila, 2013; Kirby et al., 2010; Norton \& Wolf, 2012).

However, as the accumulating research on the topic has convincingly demonstrated RAN to be multicomponential in nature, recent studies have once again raised the question of the specificity of RAN to reading and reading disabilities. Many of these studies have also found connections between RAN and math (Ackerman, Holloway, Youngdahl, \& Dykman, 2001; Koponen, Aunola, Ahonen, \& Nurmi, 2007; Koponen, Salmi, Eklund, \& Aro, 2013; van Bergen, de Jong, Maassen, \& van der Leij, 2014; van der Sluis, de Jong, \& van der Leij, 2004; Wilson et al., 2015) and RAN and attention deficits (Moll, Göbel, Gooch, Landerl, \& Snowling, 2014; Tannock, Martinussen, \& Frijters, 2000), especially the subtype of inattention without impulsivity and hyperactivity (Arnett et al., 2012; Hynd et al., 1991; Thomson et al., 2005). Some studies have suggested that 
naming speed deficits may contribute to the comorbidity between reading disabilities and math disability (Geary 1993; Geary, Hamson, \& Hoard, 2000; Wilson et al., 2015), particularly in the comorbid group of reading disability (RD) and attention deficit (Bental \& Tirosh, 2007; Rucklidge \& Tannock, 2002). In line with this, Waber, Folff, Forbes, and Weiler (2000) explored the specificity of RAN to reading in a sample that included children with $\mathrm{RD}$, math disability and ADHD-inattentive type. They found that RAN was more closely related to $\mathrm{RD}$ when it was defined as reading fluency compared to the RD definition based on accuracy. Children in the group with naming speed deficit showed more RD than children without naming speed deficit, and RAN was at its best in discriminating the RD children from controls. However, in addition to these results confirming the association between RAN and reading, the prevalence of naming speed deficit was also elevated in groups with learning difficulties without RD (non-RD), and even appeared to increase with the number of comorbid learning problems irrespective of diagnosis. The discrimination power of RAN in the non-RD vs. control comparison was about the same as in the RD vs. non-RD comparison, that is, it was significant but weaker than in the RD vs. Control comparison. Based on these results, Waber et al. concluded that RAN was associated with learning disabilities in general and not specific to reading disabilities.

However, despite the high level of comorbidity between learning disabilities (RD, math disability) and ADHD (Czamara et al., 2013; DuPaul, Gormley, \& Laracy, 2013; Landerl \& Moll, 2010; for reviews, see Boada, Willcutt, \& Pennington, 2012; Germanò, Gagliano, \& Curatolo, 2010; Sexton, Gelhorn, Bell, \& Classi, 2012, and Willcutt, Pennington et al., 2010), studies replicating the findings of Waber et al. (2000) with another clinical sample reporting RD, math disability, and attention deficit in the same study have been few (for exceptions, see Fletcher, 2005; Willcutt et al., 2013). In addition, several studies have found support for a more specific connection between RAN and RD than between RAN and other learning impairments. First, in many studies where reading fluency has been used as a measure for reading skill, RAN has not shown a unique association either with attention (Raberger \& Wimmer, 2003), or with math skills (Georgiou, Tziraki, Manolitsis, \& Fella, 2013; Landerl, Fussenegger, Moll, \& Willburger, 2009; Willburger et al., 2008; however, see Koponen et al., 2013; van Bergen et al., 2014). Second, in several studies the connection between RAN and attention deficit or RAN and math disability has vanished after controlling for other relevant variables, such as reading accuracy, IQ, or processing speed (attention deficit: Felton \& Wood, 1989; math disability: Georgiou, Tziraki et al., 2013; Moll, Göbel, Gooch et al., 2014; Willcutt et al., 2013). Finally, although more naming speed deficits may be present in attention deficit compared to normative groups, these groups have nevertheless outperformed RD groups in RAN performance (Ackerman \& Dykman, 1993; Felton, Wood, Brown, Campbell, \& Harter, 1987; Närhi \& Ahonen, 1995; Semrud-Clikeman et al., 2000; Willcutt, Betjemann, et al., 2010). 
Taken together, the evidence for a specific connection between RAN and reading is equivocal and many studies exploring the connection between RAN and math or RAN and attention have either not controlled for reading or the measure of reading has been reading accuracy, leaving the common variance of RAN and reading fluency uncontrolled. To date, the results reported by the few studies with samples including RD, math disability, and attention deficit in the same study and including a measure for reading fluency have been conflicting (Waber et al., 2000; Willcutt et al., 2013). Given that learning disabilities and attention deficits often co-occur (for reviews, see Boada et al., 2012; Germanò et al., 2010; Sexton et al., 2012, and Willcutt, Pennington et al., 2010) and may in part share a common etiology (Hart et al., 2010; Kovas et al., 2007; Willcutt, Pennington, et al., 2010), exploring RAN in clinical samples including all of the above-mentioned disabilities (here termed learning difficulties, acknowledging that the term learning disability often refers only to RD and math disability) may not only have diagnostic utility, but also yield relevant applications for planning interventions for comorbid groups. If RAN turns out to be specific to reading and reading disability, it can be used as a predictor of specific reading disabilities. If, instead, RAN proves to be an indicator of learning difficulties in general, it would be useful as a screening measure for identifying children with these broader learning difficulties; however, more importantly, such a result would also have theoretical implications that would guide future research away from a narrow RAN-reading focus towards a more eclectic understanding of rapid automatized naming.

\subsection{How is RAN related to reading?}

\subsubsection{In a search of explanations for the RAN-reading relationship}

For four decades now we know that RAN is related to reading. However, the mechanism underlying this relationship continues to be debated. Some of the proposed explanations are based on linguistic components that are usually associated with reading and may also play a part in RAN performance, others explain this connection by reference to broader processes independent of linguistic skills, and yet others analyze the process of reading and RAN phase-byphase in an effort to find sub-processes common to both of these.

The sub-processes that are suggested to be common to both RAN and reading performance naturally, in part, parallel those involved in RAN performance alone (Wolf \& Bowers, 1999, introduced above). First, the RAN-reading association may derive from visual processes like visual pattern recognition and visual discrimination (Araújo et al., 2011; Klein, 2002; Stainthorp, Stuart, Powell, Quinlan, \& Garwood, 2010). However, these explanations have not been either widely studied or supported (Di Filippo et al., 2006; Gasperini, Brizzolara, Chritofani, Casalini, \& Chilosi, 2014), while the results of deficits in visualattentional processes as a cause of poor reading skill are contradictory (Ger- 
mano, Reilhac, Capellini, \& Valdois, 2014; Ziegler, Pech-Georgel, Dufau, \& Grainger, 2010). Second, the ability to learn arbitrary sound-symbol associations is involved in both RAN and reading (Manis et al., 1999; Ziegler, Pech-Georgel et al., 2010). Third, both skills require serial processing, a notion that is supported by results showing that continuous RAN is more strongly associated with reading than discrete naming (Badian, 1993; Bowers, 1995; Bowers \& Swanson, 1991; Chiappe, Stringer, Siegel, \& Stanovich, 2002; de Jong, 2011; Denckla \& Cutting, 1999; Georgiou, Parrila, Cui, \& Papadopoulos, 2013; Meyer, Wood, Hart, \& Felton, 1998; Wolf \& Bowers, 1999; Zoccolotti et al., 2013). Fourth, impairment in precise timing mechanisms is thought to be involved in both naming speed deficits and dysfluency in reading (Bowers \& Wolf, 1993; Wolf et al., 2000; however, see Chiappe et al., 2002, for contrasting results). Finally, oral output of the names of the stimuli has been suggested to explain the connection between RAN and reading (Georgiou, Parrila et al., 2013). This explanation is supported by the stronger connection between RAN and oral reading compared to silent reading (Georgiou, Parrila et al., 2013; Moll et al., 2009; van den Boer, van Bergen, \& de Jong, 2014). Note, however, that this component cannot be fully explained by simple articulation time, as that has not been associated with either reading or RAN (Clarke, Hulme, \& Snowling, 2005; Cutting \& Denckla, 2001; Georgiou, Parrila, \& Kirby 2006; Georgiou, Parrila et al., 2013; Neuhaus et al., 2001; Obregon, 1994; see, however, the results from the next section).

Another view relating to the subcomponents of RAN suggests that the articulation time used to name the items and the pause time between naming them are differentially related to reading. The majority of the results suggest that pause time rather than articulation time explains the shared variance between RAN and reading (e.g., Anderson, Podwall, \& Jaffe, 1984; Neuhaus et al., 2001; for review, see Georgiou \& Parrila, 2013). As articulation time has been suggested to refer to response automaticity and pause time to the automaticity of phonological access (Neuhaus et al., 2001), the connection between RAN and reading can be explained through the automatization of the phonological retrieval process. However, the relational effect of these RAN components seems to change during development, the unique contribution of articulation time increasing and the effect of pause time decreasing (Georgiou, Papadopoulos, \& Kaizer, 2014). In addition, the findings vary according to the orthography in question: pause time seems to be more strongly connected with reading in nonalphabetic languages, whereas the effect on articulation time seems to be greater in alphabetic languages, reflecting the faster automatization process in the latter (Georgiou, Aro, Liao, \& Parrila, 2015), expressed even more in orthographically consistent languages (Georgiou, Parrila, \& Liao, 2008).

According to some scholars, reading disabilities are predicted not only by linguistic processes but also reflect either deficits in general processing speed or a deficit in skill automatization, both of which have also been proposed as factors explaining the RAN-reading association. Support for the idea of a deficit in general processing speed has been gained from studies in which children with dyslexia show deficits not only in reading and naming speed, but also in other 
tasks requiring effective or fast processing (Catts, Gillispie, Leonard, Kail, \& Miller, 2002; Fawcett \& Nicolson 2001; Kail \& Hall, 1994; Kail, Hall, \& Caskey, 1999; Morris et al., 1998; Wolff, Michel, \& Ovrut, 1990c). Processing speed has, in fact, been shown to explain a modest but significant part of the variance between RAN and reading fluency (Georgiou, Parrila, \& Kirby, 2009). However, the RAN-reading association cannot be fully explained by processing speed. First, if processing speed was a major factor behind the RAN-reading association, all kinds of RAN tasks would correlate with reading to a similar extent. Because alphanumeric stimuli (letters and numbers) show a stronger link with reading than non-alphanumeric stimuli (reviewed above, e.g., Christopher et al., 2012; Georgiou, Parrila, Kirby, \& Stephenson, 2008; Georgiou, Parrila, \& Papadopoulos, 2008; Manis, Doi, \& Bhadha, 2000; Misra et al., 2004; Neuhaus et al., 2001; Poulsen et al., 2015; Savage \& Fredrickson, 2006; Semrud-Clikeman et al., 2000; Stringer et al., 2004; Van den Bos, Zijlstra, \& Spelberg, 2002; Wimmer, 1993), alphanumeric RAN tasks seem to reflect a more specific linguistic processing function that cannot be not comprehensively accounted for by general processing speed. Along the same lines, there is research evidence to show that although global processing speed was found to mediate the association between non-alphanumeric naming and word-reading skill, it was not able to explain the connection between alphanumeric naming speed and word-reading skill (Bowey, McGuigan, \& Ruschena, 2005). Based on the modest connection between RAN and processing speed, many scholars have concluded that RAN's ability to predict reading is independent of processing speed (DeMann \& Thornton, 2014; Georgiou, Parrila, Kirby et al., 2008). Finally, the fact that unique variance was found for RAN in reading performance, even after controlling for processing speed (Georgiou et al., 2009; Georgiou, Parrila, Kirby et al., 2008; Powell, Stainthorp, Stuart, Garwood, \& Quinlan, 2007; Vaessen, Gerretsen, \& Blomert, 2009), while no unique variance was found for processing speed in reading, after controlling for RAN (Cutting \& Denckla, 2001), indicates that processing speed has a role in explaining the connection between RAN and reading, but is not sufficient to fully explain it (Denckla \& Cutting, 1999).

A second explanation, referring to broader deficits, automatization deficit (Nicolson \& Fawcett, 1990; Nicolson, Fawcett, \& Dean, 2001), suggests that the automatization of skilled behavior has been delayed or restricted due to a cerebellar deficit that causes impairment in implicit learning and automatization over a wide range of skills, including reading and naming. The explanation of a deficit in the general automatization process is supported in studies where individuals with dyslexia also show deficits in other skills requiring automatization, such as motor timing (Wolff, Michel, \& Ovrut, 1990a, 1990b), balancing tasks (Nicolson \& Fawcett, 1990; Yap \& Van der Leij, 1994), and motor skills in general (Morris et al., 1998). However, in some studies children with dyslexia have shown naming speed deficits but no deficits in balancing performance or other skills related to skill automatization (Raberger \& Wimmer, 2003; Wimmer, Mayringer, \& Landerl, 1998; Wimmer, Mayringer, \& Raberger, 1999). Balancing deficits, in turn, were associated with attention deficits (Raberger \& Wimmer, 
2003; Wimmer et al., 1999). The authors suggested that the automatization hypothesis may have a role in explaining naming and reading speed deficits, but restricted this idea solely to processes connecting visual and linguistic skills.

A third set of explanations on the link between RAN and reading starts with the cognitive skills most commonly associated with reading: short-term memory or working memory, orthographic processing, and-perhaps the most discussed - phonological skills. The role of verbal short term memory or working memory in explaining the relationship has not been very widely studied, and the results have been mixed, as in some studies the association between RAN and short-term memory has been non-significant or modest (Cornwall, 1992; Korhonen, 1995; Parrila, Kirby, \& McQuarrie, 2004), these skills being rather independent in predicting reading performance (Bowers, Steffy, \& Tate, 1988; Cornwall, 1992), whereas others suggest that working memory explains a part of the shared variance between RAN and reading (e.g., Arnell et al., 2009).

Some scholars have suggested that the RAN-reading association is mediated via orthographic processing (e.g., Bowers, Golden, Kennedy, \& Young, 1994; Bowers \& Newby-Clark, 2002; Bowers, Sunseth, \& Golden, 1999; Bowers \& Wolf, 1993). This view is supported by findings of a significant association between RAN and orthographic knowledge (e.g., Compton, 2000; Conrad \& Levy, 2007; Georgiou et al., 2009; Georgiou, Parrila, Kirby, et al., 2008; Holland, McIntosh, \& Huffman, 2004; Manis et al., 1999; Manis et al., 2000; Roman, Kirby, Parrila, Wade-Woolley, \& Deacon, 2009) and that the shared variance between RAN and reading accuracy was accounted for by orthographic knowledge (Roman et al., 2009). In addition, speeded letter recognition in children with naming disabilities improved more when the intervention included the practicing of orthographic skills (Conrad \& Levy, 2011). However, some research results are problematic for the view that RAN is part of orthographic processing. First, not all studies have verified the hypothesized association between RAN and orthographic skills (Bowey \& Miller, 2007; Jiménez et al., 2008; Moll et al., 2009; Papadopoulos et al., 2009). Second, the relationship between RAN and orthographic processing does not appear to be stable, as their correlation increases during the development of reading (Georgiou, Parrila, Kirby et al., 2008). Third, spelling deficits often associated with problems in orthographic processing have been shown to manifest without any naming speed deficits (Moll \& Landerl, 2009; Wimmer \& Mayringer, 2002). Finally, despite the significant association found between RAN and orthographic processing, RAN has had unique variance in predicting reading fluency after controlling for orthographic processing (Cutting \& Denckla, 2001; Georgiou et al., 2009; Zoccolotti, De Luca, Marinelli, \& Spinelli, 2014), and the association between RAN and orthographic processing has disappeared after controlling for processing speed (Cutting \& Denckla, 2001). As the results of Powell et al. (2014) in their recent article show, the question on the RAN-orthography relationship is far from resolved, as the different aspects of orthographic processing may vary in their association with RAN (Powell et al., 2014; see also discussion in Georgiou et al., 2009). 
Much research has been conducted on the question whether RAN is part of the family of phonological skills, along with phonological awareness and phonological short-term memory, or whether it is a skill independent of phonology. There are several proponents of the first view, according to which RAN can be subsumed under phonological processing skills as it basically reflects an ability to efficiently retrieve phonological representations from long term memory, thus rendering it a useful measure of phonological access (Bowey et al., 2005; Kibby, Lee, \& Dyer, 2014; Pennington et al., 2001; Ramus 2014; Ramus \& Szenkovits, 2008; Savage, Pillay, \& Melidona, 2007; Torgesen, et al., 1997; Vaessen et al, 2009; Vellutino, Fletcher, Snowling, \& Scanlon, 2004; Wagner et al., 1997). On a broader view of the construct of phonological skills, RAN has also been subsumed under this heading as a measure of lexical retrieval (i.e., access or retrieval of lexical phonological representations, Pennington et al., 2001; Ramus \& Szenkovits, 2008; Wagner \& Torgesen, 1987). However, the role of RAN as component of phonological skills has been discussed, and also questioned, perhaps more than any other of the views introduced above. One of the strongest alternatives to this phonological view is the double-deficit hypothesis (Wolf \& Bowers, 1999), introduced in more detail in next section. Other perspectives questioning the phonological view point out that although RAN obviously shares some characteristics with phonological skills (Denckla \& Cutting, 1999), these characteristics are not sufficient to explain the RAN-reading relationship (Jones, Branigan, Hatzidaki, \& Obregón, 2010; Powell et al., 2007), and that RAN continues to predict reading after controlling for phonological awareness and/or phonological short-term memory (Bowers et al., 1988; Kirby et al., 2003; Manis et al., 2000; Parrila et al., 2004). In addition, results in which RAN predicted reading performance better than discrete naming (i.e., a more classical measure of lexical access) were interpreted to mean that RAN cannot be subsumed under lexical access of phonological stimuli (Logan, Schatschneider, \& Wagner, 2011).

While each of the perspectives presented above have been both supported and criticized, the question of what underlies the connection between RAN and reading continues to await a comprehensive answer. In studies exploring these viewpoints, while it has been shown that RAN shares a significant part of its predictive variance on reading fluency with processing speed, phonological awareness, phonological short-term memory, letter knowledge, and orthographic processing, RAN survives as a predictor of reading fluency even after controlling for these variables (Georgiou et al., 2009; Georgiou, Papadopoulos, Fella, \& Parrila, 2012; Georgiou, Tziraki et al., 2013; Poulsen et al., 2015; for a review, see Kirby et al., 2010). Perhaps the broadest (but evidently not safest) conclusion on this question may be to join Norton and Wolf (2012) in their assertion that RAN acts "as a microcosm of the reading system, providing an index of one's abilities to integrate multiple neural processes" (p. 448). In line with this statement, we have concluded that RAN shares most of the processes of fluent (or non-fluent) reading, and cannot be fully subsumed under any of the single sub-processes of reading. 


\subsubsection{RAN as an independent predictor of reading disabilities: the double- deficit hypothesis}

As noted in the previous section, none of the other correlates of reading have been able to fully explain the common variance between RAN and reading. In addition, none of the single predictors of reading has succeeded alone in explaining the different manifestations of reading disabilities. Thus, the doubledeficit hypothesis (DDH, Wolf \& Bowers, 1999, 2000) was developed to broaden the scope of the predictors of reading towards multiple deficit models (see also Pennington, 2006). The DDH brought RAN as a specific and independent predictor of reading disability (RD) together with phonological deficit, which had previously been the dominant explanation for reading disabilities (e.g., Stanovich \& Siegel, 1994; Vellutino et al., 2004). The DDH posits that RAN and phonological awareness both predict reading disabilities and are for the most part independent of each other (Wolf \& Bowers, 1999). Children with deficits in phonological awareness and RAN can be assigned to three different groups: naming speed deficit, phonological deficit, and double-deficit, where both deficits are combined. It is assumed that the most severe reading disabilities are manifested in the double-deficit group, which reflects the additive nature of naming speed deficit and phonological deficit.

A number of studies have been able to replicate and confirm the DDH in several languages and in samples with variety of reading skills (for reviews, see Georgiou \& Parrila, 2013; Kirby et al., 2010, and for the most recent results, see Norton \& Wolf, 2012; Cronin, 2013; Steacy, Kirby, Parrila, \& Compton, 2014 Torppa et al., 2012; Torppa et al., 2013). Several results support the independent role of RAN as a predictor of reading disabilities. First, the association between RAN and phonological awareness has been modest from a statistical point of view, as the correlations between RAN and phonological awareness have been modest; in factor analysis RAN and phonological awareness have loaded on separate factors (reviewed by Swanson, Trainin, Necoechea, \& Hammill, 2003), and RAN and phonological awareness have been shown to have unique variance in reading ability in regression and structural equation models (e.g., Compton, DeFries, \& Olson, 2001; Cutting \& Denckla, 2001; Katzir et al., 2006; Powell et al., 2007). Second, the neuroimaging studies (Norton et al., 2014; for a review, see Norton, Beach, \& Gabrieli, 2015) and also genetic studies (Byrne et al., 2005; Naples et al., 2009; however, see Petrill et al., 2006) suggest, at least in part, a separate biological basis for RAN and phonological awareness. Third, the DDH groups have shown fairly high stability over time with no transitions between the single-deficit groups (phonological deficit and naming speed deficit; Steacy et al., 2014; however, see Spector, 2005). Fourth, RAN and phonological awareness have been associated with the separate aspects of reading skills, as phonological awareness has proven to have stronger associations with reading and spelling accuracy while RAN has primarily been associated with reading speed and fluency both in transparent orthographies (Kairaluoma, Torppa, Westerholm, Ahonen, \& Aro, 2013; Papadopoulos et al., 2009; Torppa et al., 2012; Vaessen et al., 2009; Wimmer et al., 2000) and in English (Compton et al., 
2001; Cornwall, 1992; Pennington et al., 2001; Schatschneider, Carlson, Francis, Foorman, \& Fletcher, 2002; Sunseth \& Bowers, 2002), a result also confirmed by cross-linguistic studies (Furnes \& Samuelsson, 2011; Moll, Ramus et al., 2014; Vaessen et al., 2010). Finally, interventions based on phonological processing have failed to improve naming speed or word reading fluency (Regtvoort \& van der Leij, 2007).

Not all studies, however, have found support for the DDH (for a review, see Vukovic \& Siegel, 2006). One of the most obvious reasons for this result is that in these studies reading has been measured only by reading accuracy or reading disabilities have been defined on the basis of accuracy-based measures, leaving the common variance of RAN and reading fluency uncontrolled. In addition, the age when phonological awareness, RAN, and reading are evaluated may influence on the results. In their longitudinal study, Parrila et al. (2004) found that the commonality between RAN and phonological awareness declined over time, which means that in later grades these skills predicted reading in a more unique way than they did at the beginning of school. Therefore, it is expected that in studies investigating DDH in the early grades of schooling the unique role of RAN may be less prominent than in the later grades. Another criticism levelled at the DDH is that RAN may rather reflect the speed of the process of integrating the associations between phonological and orthographic information, a process that is also represented in phonological awareness. This view is supported by findings where speeded measures of phonological awareness have accounted for part of the variance of RAN (Arnell et al., 2009) and reduced the shared variance between RAN and reading (Vaessen et al., 2009). However, even timed measures of phonological processing were not able to outperform RAN in explaining reading speed in these studies, a finding that continues to support the unique role of RAN in predicting reading speed.

In conclusion, the majority of the studies exploring the DDH have found support for the independent roles of phonological awareness and RAN in explaining reading performance, as the correlation between phonological awareness and RAN has been modest and these skills predict distinct aspects of reading (accuracy vs. rate). However, experimental studies have not produced solid agreement on the premise of the DDH that the double-deficit group is characterized by the most severe reading disabilities (for a review, see Georgiou \& Parrila, 2013). To date, only a few studies have replicated DDH with a clinical sample taking into account the comorbid problems that (as mentioned earlier) may be related to RAN performance. The studies addressing comorbidity have indicated that the double-deficit group is characterized by more comorbid deficits than the other groups (Ackerman et al., 2001; Waber, Forbes, Wolff, \& Weiler, 2004). These studies have defined RD based on reading accuracy, which may lead to confounding effects, as reading fluency has not been controlled for. However, in a study with a non-selected sample of Finnish children where reading was measured by fluency, more deficits in attention and hyperactivity were evident in the double-deficit group than in the other groups based on the DDH (Torppa et al., 2013), which lends further support to the hypothesis that 
the double-deficit group is more prone to comorbid problems. One of the aims of this research was to clarify the role of RAN and phonological awareness in a clinical sample, taking into account not only the various aspects of literacy (reading accuracy and fluency, and spelling) but also the presence of comorbid problems in math and attention.

\subsubsection{RAN and reading in orthographies varying in transparency}

Despite the consistent findings on an association between RAN and reading fluency across languages, it has been suggested that the role of RAN in predicting reading may be further emphasized in languages with a more transparent orthography (for reviews, see e.g., Kirby et al., 2010; Wolf et al., 2000). This may be due to differences in reading development between languages varying in orthographic transparency: while reading accuracy reaches its ceiling soon after school entry in transparent orthographies like Finnish, the development of accurate decoding skills takes considerably more time in less transparent orthographies, especially English (Seymour, Aro, \& Erskine, 2003). Thus, although the process of reading development may be rather similar across languages, the lengths of these developmental courses will differ depending on the orthography in question (Caravolas, Lervåg, Defior, Málková, \& Hulme, 2013; Vaessen et al., 2010). It follows that the period for phonological awareness as a predictor of reading skill is likely to be shorter in transparent orthographies due to the faster development in reading accuracy (Aarnoutse, van Leeuwe, \& Verhoeven, 2005; Elliot \& Grigorenko, 2014; Papadopoulos et al., 2009; Torppa et al., 2012; Wimmer et al., 2000). A smaller variance in reading accuracy after the initial phases of reading leaves reading speed with a proportionally greater amount of the total variance in explaining reading performance. This, in turn, may highlight the predictors associated with reading speed (i.e., RAN; Landerl \& Wimmer, 2008). This is in accordance with results where RAN has outperformed phonological awareness as a predictor of reading performance not only in transparent languages already soon after school entry (de Jong \& van der Leij, 1999, 2002), but also in less transparent languages when followed until the initial phase of reading has been passed (Christopher et al., 2015; Georgiou et al., 2009; Juul, Poulsen, \& Elbro, 2014; Kirby et al., 2003; Vaessen et al., 2010). Based on these findings, it has been concluded that RAN serves as a robust predictor of reading performance across languages (Georgiou, Parrila, \& Liao, 2008; Moll, Ramus et al., 2014; Norton \& Wolf, 2012), whereas the relation between RAN and phonological awareness during the reading development remains an open question, as shown by the conflicting results (see e.g., Caravolas et al., 2012; 2013; Furnes \& Samuelsson, 2011; Landerl et al., 2013; Wagner et al., 1997). The discrepancies between these results are difficult to fully interpret because crosslinguistic studies on the effects of orthographic transparency are in many ways non-comparable owing to methodological differences. Considerable variation exists in design (cross-sectional vs. longitudinal), measures for key variables (RAN, phonological awareness, reading), age groups, and samples (normative vs. poor reading). 
Studies with Finnish samples have consistently found a strong association between RAN and reading fluency in non-selected samples of children (Holopainen, Ahonen, \& Lyytinen, 2001; Lepola, Poskiparta, Laakkonen, \& Niemi, 2005; Torppa et al., 2013) as well as in children with reading disabilities (Korhonen, 1995; Lyytinen et al., 2006), or both (Kairaluoma et al., 2013; Torppa et al., 2012), and in groups with naming disabilities (Berg et al., 2014; Salmi, 2008). Consistent with the findings from other transparent languages, reading accuracy in Finnish reaches a very high level very fast (Aro, 2006; Aro \& Wimmer, 2003; Seymour et al, 2003) and is relatively high even among children with reading difficulties (Huemer, Aro, Landerl, \& Lyytinen, 2010). Although phonological awareness (Leppänen, Niemi, Aunola, \& Nurmi, 2006; Lyytinen et al., 2006; Torppa et al., 2007; 2013) and letter knowledge (Georgiou, Torppa et al., 2012; Leppänen et al., 2006; Lyytinen et al., 2006; Puolakanaho et al., 2008; Torppa, Poikkeus, Laakso, Eklund, \& Lyytinen, 2006; Torppa et al., 2007; 2013) have been shown to reliably predict reading performance in the initial stages of reading, predicting reading performance (i.e., reading fluency) at later stages has been proven to be more challenging (Heinola, Latvala, Heikkilä, \& Lyytinen, 2010; Puolakanaho et al., 2008). The few studies that have investigated reading after the first grade in Finnish have found that reading fluency is best predicted by RAN performance (Holopainen et al., 2001; Torppa et al., 2007). However, the results of cross-linguistic studies that have included Finnish samples (Georgiou, Torppa et al., 2012; Moll, Ramus et al., 2014; Ziegler, Bertrand et al., 2010) have contradicted the findings from many other studies in transparent languages, as no strong connection emerged between RAN and reading fluency in Finnish. The problem is that none of these studies explored children with reading disabilities and only one of them (Georgiou, Torppa et al., 2012) was longitudinal. They also varied in their use of measures (e.g., RAN objects in Ziegler, Bertrand et al., 2010). Therefore more studies are needed to clarify the role of RAN in reading development in Finnish in comparison to other orthographies.

From the perspective of this research, research evidence continues to be lacking on one of the important issues. The overwhelming majority of the studies predicting reading in transparent languages have concentrated on the early phases of reading development. This means that studies on reading in Finnish after second or third grade are almost nonexistent (for an exception, see Kairaluoma et al., 2013) or they have not included RAN as a predictor (e.g., Leppänen, Aunola, Niemi, \& Nurmi, 2008). Based on the findings presented above, it could be argued that reading performance in the early stages of reading is qualitatively different from that manifested in the later phases of reading, while the correlates of reading may also have a different weight in the later phases than at the beginning of reading instruction. It is, therefore, important to explore how the connections between RAN, phonological awareness, and different aspects of literacy skills (reading accuracy, reading speed, and spelling) are manifested in Finnish after the second grade of schooling, when the fluency phase is expected to be reached. 


\subsubsection{RAN in a continuum of reading skills}

In addition to the orthography of interest, the continuum of reading skill has to be taken into account when examining the association between RAN and reading. This continuum can be viewed from two perspectives: from the phases typical of reading development (from the pre-literate and initial phases of reading in contrast to more advanced reading) and from a comparison between typical and atypical reading development (i.e., reading disabilities). These perspectives are partially overlapping, as similarities exist between reading performance in the initial phases of reading and dyslexic reading. However, there may also be qualitative differences between these groups that require them to be treated as separate entities (see the discussion in Francis, Shaywitz, Stuebing, Shaywitz, \& Fletcher, 1996) especially when exploring the connection between RAN and reading (Meyer et al., 1998).

As discussed above, the normative development of reading in transparent languages leads very rapidly to accurate decoding while reading fluency takes more time to develop. Although RAN has been primarily associated with reading fluency, it has also been shown to have a role in predicting decoding accuracy in the initial phases of reading (e.g., Juul et al., 2014; Schatschneider et al., 2004). RAN can be measured, using non-alphanumeric stimuli (objects and colors), already before any reading instruction is given, and it has been proven to be a reliable indicator of later reading skills and reading difficulties (De Jong \& van der Leij, 2003; Lervåg \& Hulme, 2009; Puolakanaho et al., 2007; Reiter, 2001; Schatschneider et al., 2004; Wolf et al., 2000). After being acquainted with letters and numbers in school, alphanumeric stimuli seem to correlate more strongly with reading skills (reviewed above in the introduction). Based on cumulative findings, it seems that before school age and in the first phases of reading RAN seems to be related to a variety of reading skills (reading accuracy, reading speed, reading comprehension, and spelling, reviewed above in the introduction). Later on, as the connection between RAN and reading accuracy decreases, the connection between RAN and reading fluency might get relatively stronger (e.g., Georgiou et al., 2006, 2009; Georgiou, Parrila, Kirby et al., 2008; Torppa et al., 2013; Vaessen \& Blomert, 2010). Some researchers, however, have suggested that RAN may be more strongly associated with reading in the early stages (Allor, 2002; McBride-Chang \& Manis 1996), and may decline over time (Torgesen et al., 1997; Wagner et al., 1997). This is not in conflict with the findings presented above, since in these studies reading has been assessed with accuracy measures and reading fluency has not been taken into account. It is also possible that children with slow reading speed may compensate for their difficulties by guessing, which predisposes their reading to errors (Juul et al., 2014). Thus, it may be concluded that the association between RAN and reading accuracy may decrease during reading development whereas the connection between RAN and reading fluency continues to predict reading performance (Georgiou, Parrila, Kirby, et al., 2008). 
A more relevant aspect from the perspective of this research is to compare the association between RAN and reading in samples with normative reading development versus reading disabilities. Several studies from various age groups have concluded that the association between RAN and reading appears to be stronger among dyslexic readers than in typically developing readers (Allor, 2002; Araújo et al., 2011; Cardoso-Martins \& Pennington, 2004; Hammill, Mather, Allen, \& Roberts, 2002; McBride-Chang \& Manis 1996; Meyer et al., 1998; Pennington et al., 2001; Scarborough 1998; Wolf \& Bowers, 1999), possibly because of a curvilinear relationship between reading performance and naming speed (Kirby et al., 2010). Also, a threshold for naming speed has been suggested, meaning that a slow naming speed would hinder reading development (Bowers, 2001) whereas naming above the threshold would not bring any advantage to reading (Walsh, Price, \& Gillingham, 1988). This notion is supported by results in which RAN discriminated between poor and average readers but not between average and above average readers (Savage et al., 2005). However, firm conclusions on this question are hard to draw as the majority of the studies comparing good and poor reading in relation to RAN have been conducted with English as the target language (except for Araújo et al., 2011, in Portuguese) and the connection between RAN and reading fluency was explored in only three of them (Araújo et al., 2011; Cardoso-Martins \& Pennington, 2004; Pennington et al., 2001).

While more research is needed to confirm the stronger connection between RAN and reading in dyslexic than normative groups in transparent languages and with measures of reading fluency, a rather strong connection between RAN and reading fluency can be expected in dyslexic samples in Finnish. Although the RAN-reading connection has not always been as strong as expected in samples with typical reading skills (Moll, Ramus et al., 2014; Ziegler, Bertrand et al., 2010), results among poor readers in Finnish have consistently shown a strong association between reading fluency and RAN (Kairaluoma et al., 2013; Korhonen, 1995; Lyytinen et al., 2006; Torppa et al., 2012). The abovementioned studies cover the age groups from birth to third grade, and also adolescents, but no measurements have been conducted at the ages between. Exploration of the RAN-reading connection among children with poor reading skill is within the scope of this study in seeking to specify more precisely to what extent RAN predicts reading accuracy and reading speed in a language Finnish - with a transparent orthography, at an age where accurate reading has, normatively, already been acquired and fluency development takes place (Juul et al., 2014; Kuhn \& Stahl, 2003; Seymour et al., 2003; Torppa et al., 2012; Zoccolotti, De Luca, Di Filippo, Judica, \& Martelli, 2009). 


\subsection{Reading fluency intervention}

\subsubsection{Reading fluency intervention in transparent orthographies}

Reading fluency refers to the ability to read accurately at an adequate speed, and, in the case of oral reading, with good prosody (Kuhn \& Stahl, 2003; National Institute of Child Health and Human Development, 2000). Reading fluency has long been neglected in interventions, most likely because of the stress on reading accuracy that has been at the center of intervention studies (Share, 2008). However, as knowledge of the differences between languages in the manifestation of reading disabilities has accumulated, and the dysfluency of reading has been acknowledged as a universal characteristic of dyslexia across languages (Ziegler, Perry, Ma-Wyatt, Ladner, \& Schulte-Körne, 2003) and as the main characteristic of RD in transparent orthographies (e.g., Escribano, 2007; Holopainen et al., 2001; Protopapas \& Skaloumbakas, 2007; Serrano \& Defior, 2008; Wimmer, 1993; Yap \& van der Leij, 1993; Zoccolotti et al., 1999), research interest on reading fluency and its intervention has also increased.

The reason why reading fluency is a crucial part of successful reading is that it is associated not only with reading comprehension (Berninger et al., 2010; Fuchs, Fuchs, Hosp, \& Jenkins, 2001; Kim, Petscher, Schatschneider, \& Foorman, 2010; Klauda \& Guthrie, 2008; Schwanenflugel et al., 2006; Therrien, 2004; Wise et al., 2010) but also with motivation towards reading (Leinonen et al., 2001; Meyer \& Felton, 1999). The connection between reading fluency and comprehension is explained by an automatization process, which is thought to free processing capacity from decoding to text understanding (LaBerge \& Samuels, 1974; Perfetti, 1985; however, see Adlof, Perfetti, \& Catts, 2011). The process of acquiring reading fluency is thought to be gradual (Kame'enui \& Simmons, 2001), and a product of continuous independent practice (self-teaching; Share, 1995). This process is in many cases slower than gaining decoding accuracy, which appears to be acquired very fast in transparent orthographies (Seymour et al., 2003). For children with reading disabilities, problems in fluency have turned out to be very persistent (de Jong \& van der Leij, 2003; Eklund, Torppa, Aro, Leppänen, \& Lyytinen, 2015; Landerl \& Wimmer, 2008) and rather difficult to remediate, at least with respect to normative levels of reading (Meyer \& Felton, 1999; Thaler, Ebner, Wimmer, \& Landerl, 2004; Wanzek et al., 2013). Despite these facts, studies on reading fluency interventions have shown that significant increases in reading fluency can be achieved (for reviews, see Chard, Vaughn, \& Tyler, 2002; Huemer, 2009; Kuhn \& Stahl, 2003; Therrien, 2004; Wolf \& Katzir-Cohen, 2001) and that these gains have in some studies promoted reading comprehension (Breznitz, 2006; Therrien, 2004; however, see Gellert, 2014; Scammacca et al., 2007; Soriano, Miranda, Soriano, Nievas, \& Felix, 2011). So far, the training effect for reading fluency has often been modest compared to the effects achieved in decoding, word identification, or reading comprehension (for reviews, see Flynn, Zheng, \& Swanson, 2012; Galuschka, Ise, Krick, \& 
Schulte-Körne, 2014; Suggate, 2014; however, see Wanzek et al., 2013, where the effects of different interventions were highly comparable). There are a number of possible reasons for this. First, in many studies the emphasis of the training methods used has been on accuracy or reading comprehension, while efforts at training fluency directly have had a minor role in the intervention (e.g., Flynn et al., 2012; Torgesen et al., 2001). Second, the number of reading fluency interventions in comparative review studies has often been small, which clearly reflects the fact that methods for use in reading fluency interventions are still in the process of development. Third, to develop, reading fluency requires a rather long process of automatization (Kame'enui \& Simmons, 2001), which since it cannot be acquired by explicit teaching may reduce the effect of the intervention. It seems, however, that interventions targeting multiple skills (e.g., naming speed, orthographic skills, reading) appear to be the most effective in facilitating not only reading fluency but also naming speed (e.g., Wolf, Miller, \& Donnelly, 2000; for review, see Kirby et al., 2010).

As the reviews on different reading fluency interventions have been presented elsewhere (e.g., Chard et al., 2002; Huemer, 2009; Kuhn \& Stahl, 2003; Therrien, 2004; Wolf \& Katzir-Cohen, 2001), only their conclusions need be summarized here. The most common evidence-based method used in reading fluency interventions has been repeated reading of words, texts, or sublexical items. Repeated reading has been shown to be effective in increasing reading fluency of the practiced items or materials. However, the training effects have often been specific to the materials trained, that is, the transfer effect to other contents has been weak or non-existent (e.g., Berends \& Reitsma, 2006; Thaler et al., 2004). Therefore, the selection of the materials to be used in training is one of the crucial questions to be addressed in a repeated reading intervention. In many languages, common words serve as a good choice for training repeated reading as most of these words are short and a small number of words comprise a significant proportion of the words across different texts. However, the Finnish language is characterized by an inflectional morphology where morphemes are agglutinated within a word, increasing word length and also generating numerous word forms (based on case and number; Karlsson, 2008). Thus, repeated reading of all the common forms of the common words in Finnish would be an inefficient way to promote reading fluency, leaving a need for suitable sub-lexical units as materials for fluency training. There are also other facts supporting the training of sub-lexical units larger than phonemes. First, while phonics instruction appears to be effective in promoting decoding skill (for a review, see Galuschka et al., 2014), it has not always proven sufficient for gaining fluency on the word level or on acquiring the fast recognition of sublexical orthographic units larger than phonemes (for review, see Stainthorp, 2014). Second, it seems that in languages with very regular grapheme-phoneme correspondences it is possible for readers to adopt a serial letter-by-letter reading strategy (Frost, Katz, \& Bentin, 1987; Pagliuca \& Monaghan, 2010; Ziegler \& Goswami, 2005), which sets limits to reading fluency. Thus, it is suggested that a reading intervention should have an additional focus on teaching "sub-word 
orthographic-phonological connections relating to larger units" (Stainthorp, 2014, p. 2). Third, the previous studies with sublexical items, such as consonant clusters (Hintikka, Landerl, Aro, \& Lyytinen, 2008; Marinus, de Jong, \& van der Leij, 2012), syllables (Huemer et al., 2010; Tressoldi, Vio, \& Iozzino, 2007), and morphemes (Burani, Marcolini, De Luca, \& Zoccolotti, 2008), have been shown to be effective in promoting reading skill in transparent languages, and such efforts have also been reported to be fruitful in English (for a review, see Stainthorp, 2014).

One of the best candidates proposed for reading fluency training in Finnish is the syllable, justified for instance by the polysyllabic nature and clear syllable structure of the language (see also the introduction in Huemer et al., 2010). It is also proposed that multisyllabic words, or nonwords that cannot be recognized as a whole, be analyzed and broken down into syllables (multiple-trace memory model; Ans, Carbonnel, \& Valdois, 1998), which supports the use of syllables as training units in languages characterized by polysyllabic words. Previous studies in languages with a clear syllable structure have shown significant increase in reading fluency after syllable training (Finnish: Huemer et al., 2010; Italian: Tressoldi et al., 2007; and Dutch: Wentink, van Bon, \& Schreuder, 1997). Obviously, increased fluency in reading syllables is not sufficient to promote fluency in reading words and texts without a transfer effect from sublexical to word-level items. However, the first results on the direct training of syllables appear promising: in their study of repeated reading of syllables, Huemer et al. (2010) were able to show a transfer effect from infrequent syllables to pseudowords containing the practiced syllables. This indicates a need for studies showing the same effect for more frequent items that are evidently more relevant for everyday reading. Accordingly, the basic questions addressed by this research were: Can reading fluency be treated in the Finnish language by syllable training based on repeated reading, and, if so, how does naming speed affect the training result?

\subsubsection{The effect of RAN in reading fluency intervention}

Some facts about the RAN-reading relationship give us reasons to believe that RAN performance is one of the candidates mediating the results of reading fluency intervention. First, RAN is closely connected with reading fluency (Kirby et al., 2010; Norton \& Wolf, 2012), which makes it one of the prerequisites of reading fluency. Second, while it seems difficult to increase naming speed by an intervention targeted solely on naming skills (Conrad \& Levy, 2011; de Jong \& Vrielink, 2004; Salmi, 2008), some studies have found an increase in naming speed as an outcome of reading fluency training (Wolff, 2014). Most importantly, the gains in RAN have also had an effect on reading fluency; even the effect has not been of very long duration (Fugate, 1997). Finally, in several studies RAN has had an effect on the results of reading interventions: the response to a reading intervention has been smaller for children with slow naming speed compared to children with higher RAN scores (Berninger et al., 1999; 2002; Bowers, 1993; Fletcher et al., 2011; Levy, Bourassa, \& Horn, 1999; Mathes et al., 
2005; Stage, Abbott, Jenkins, \& Berninger, 2003; Vadasy, Sanders, \& Abbott, 2008; Vaughn, Linan-Thompson, \& Hickman, 2003; for reviews, see Al Otaiba \& Fuchs, 2002, and Bowers, 2001). In their review, Nelson, Benner, and Gonzalez (2003) identified RAN as the factor that had most effect on treatment responsiveness; the same result has also been confirmed in a transparent language (Dutch: Scheltinga, van der Leij, \& Struiksma, 2010, for a review, see also van der Leij, 2013). However, slow naming speed has not always had an effect on reading fluency training (Levy, Abello, \& Lysynchuk, 1997), especially if the initial reading level has been controlled for (Berends \& Reitsma, 2006).

To set RAN in its context, RAN is evidently one, but not the only one, agent affecting reading fluency on its broad definition (accurate and fast reading with good prosody). Problems in reading fluency can theoretically derive from a deficiency in recognizing individual words (for which RAN is one of the predictors), in being sensitive to prosodic cues, or in semantically integrating words, meaning, and ideas (Meyer \& Felton, 1999). Like RAN, reading fluency is a multi-componential skill, including "perceptual, phonological, orthographic, and morphological processes at the letter, letter-pattern, and word levels, as well as semantic and syntactic processes at the word level and connected-text level" (Wolf \& Katzir-Cohen, 2001, p. 219), which leads to the notion that reading fluency can be hampered at many levels and in many sub-skills. In addition, the cumulative effects of the reading experience, reading motivation, and comorbid problems affecting reading obviously have their share in explaining reading fluency. In fact, predicting reading fluency from earlier precursors has proven to be a complicated task (Heinola et al., 2010; Puolakanaho et al., 2008). However, some specific cognitive skills have been shown to be reliable in predicting reading fluency (i.e., speed of accurate response to oral reading tasks). These predictors include letter knowledge (e.g., Georgiou, Torppa et al., 2012; Leppänen et al., 2008; Puolakanaho et al., 2008; Torppa et al., 2007; 2013), phonological awareness (Al Oitaba \& Fuchs, 2002; Mathes et al., 2005; Torppa et al., 2007; 2013), vocabulary (Al Oitaba \& Fuchs, 2006), verbal memory (Al Oitaba \& Fuchs, 2006), autoregressor of reading (Hammil, 2004; Torppa et al., 2013) and RAN (Al Oitaba \& Fuchs, 2002; 2006; De Jong \& van der Leij, 1999; Georgiou, Parrila \& Papadopoulos, 2008; Lepola et al., 2005; Mathes et al., 2005; Papadopoulos et al., 2009; Scheltinga et al., 2010; Torppa et al., 2013); however, these predictors may be different for children with typically developing reading fluency and for those at risk for reading difficulties (Torppa et al., 2013). According to several results from studies on transparent orthographies, RAN has emerged as the most effective predictor of reading fluency (Aarnoutse et al., 2005; Georgiou, Parrila, \& Papadopoulos, 2008; Holopainen et al., 2001; Scheltinga et al., 2010; Torppa et al., 2007; Wimmer et al., 2000). Despite the fact that RAN has been proven to be a strong predictor of development in reading fluency, the effect of RAN performance on fluency training has seldom been investigated in transparent languages (see Scheltinga et al., 2010 for exception), and has not been previously investigated in Finnish. Addressing this gap was one of the goals of this research. 


\subsection{Aims of the research}

This research aimed to clarify the role of rapid automatized naming (RAN) in the field of learning disabilities and intervention. The main goal was to produce diagnostically and clinically relevant knowledge on RAN that would clarify the usefulness of measuring naming speed in clinical settings. Whereas the majority of RAN-related studies have been conducted within a framework of reading research, in this research the framework was broadened to include other developmental disorders that often overlap with reading disabilities, namely math disability and attention deficits. Also, the connection between RAN and reading was explored further by including both reading accuracy and speed in the analyses and by replicating the existing research on the double-deficit hypothesis in a Finnish sample of children with learning difficulties. Finally, the role of RAN in a reading intervention was explored with the aim of training reading speed, a highly relevant skill for fluent reading in a transparent orthography.

The aim of Study I was to explore whether RAN was a specific predictor of reading skill or if it was a more universal predictor of learning difficulties. RAN's ability to discriminate between children with and without reading and learning difficulties was explored in a clinical sample with deficits in reading, math, and/or attention and a control group. Also the impact of comorbidity on the prevalence of naming speed deficits was evaluated.

In Study II, the aim was first to investigate the role of RAN as a skill underlying reading ability within the framework of the double-deficit hypothesis (Wolf \& Bowers, 1999), where RAN and phonological awareness are construed as independent predictors of reading disabilities. The second aim of the study was to replicate the previous findings on the specificity of RAN to reading disabilities by exploring comorbid deficits in math and attention in groups formed on the basis of the double-deficit hypothesis.

Study III aimed to increase reading speed with specific repeated reading practice, with RAN as one of the predictors of the training results. A connection between RAN and reading speed has been verified in several studies - slow namers are also slow readers. However, the role of RAN in predicting the effect of an intervention has not been as clear-cut. The effect of training as well as of the effect of RAN on the training results was explored in three intervention groups and a control group, the members of all of which had been identified as poor readers by a special education teacher, during a short but intensive intervention period. 


\section{METHODS}

\subsection{Participants}

In Studies I and II, the participants were children who had been referred to a child neuropsychological clinic for an evaluation of learning disabilities. All of them manifested school-related or learning problems, of which the most common were reading disability (RD), attention deficit, and mathematics disability. The sample recruited for Study I $(n=193)$ was the same sample as previously reported in Närhi et al. (2005), while the Study II sample $(n=205)$ consisted of children recruited during the later phases of the data collection. The inclusion criteria for both studies were Finnish as a mother tongue, verbal or performance IQ above 80 on the Wechsler Intelligence Scale for Children (WISC-R or WISCIII; Wechsler, 1974; 1991), and no acquired central nervous system damage or physical illness that had resulted in excessive absence from school. The children in Study I were aged 8-11 years and those in Study II 8-13 years. Although the participants in Studies I and II were drawn from the same clinic applying similar inclusion criteria, the samples did not overlap, and the measures used differed in part from each other, as during the study period older methods were replaced with updated ones. All children in Studies I and II were from middleclass families and came from the region of Central Finland.

Study III consisted of poor readers $(n=150)$ in the second and third grade. All the children were in classes following the normal national curriculum. The inclusion criteria for this study were Finnish as a primary language, use of the part-time special education services owing to reading problems but with acquired basic decoding skill (word reading accuracy not below -2 SD from the mean of the sample), and no multiple deficits in learning or cognition (i.e., of full-time special education status or reported neurological problems). The reading level of the final sample was comparable to that of dyslexic readers in a widely reported dataset from a Finnish longitudinal study (Jyväskylä Longitudinal Study of Dyslexia; see, e.g., Torppa, Lyytinen, Erskine, Eklund, \& Lyytinen, 2010). 


\subsection{Measures and design}

Table 1 gives an overview of the design, groups and the measures used in Studies I-III. Studies I and II were cross-sectional studies, while Study III was an intervention study with pre- and post-intervention measurements. More detailed descriptions of the measures used are presented in the original articles.

In Study I, the connection between RAN and learning difficulties was investigated using receiver operating characteristic (ROC) analysis to estimate how accurately RAN performance predicted group membership based on learning difficulties or on learning difficulties with RD both compared to each other and to the normative group (Control). RD was defined separately for reading speed and accuracy. Comparison with a previous study (Waber et al., 2000), which was replicated here, was made by manually calculating the Zscore or $x^{2}$-values for the prevalences and areas under the ROC curve.

The double-deficit hypothesis was explored in Study II by comparing the four groups based on the hypothesis (double-deficit, single deficits in naming and phonology, no deficit) in reading accuracy and speed and spelling, and also in math performance and attention ratings. This was done with analyses of variance controlling for age. The single and comorbid groups of deficits in reading, math and/or attention were cross-tabulated with the double-deficit groups to see if higher deficits in RAN or phonology are associated with higher comorbidity of learning difficulties.

In Study III, the children participating in the study were randomly divided into three training groups and a control group. The intervention effects of repeated recognition of syllables in the three intervention groups were compared to control group values with mixed-method ANOVA, training condition serving as a between-subjects factor and time (two measurement points) as a within-subjects factor. Significant interactions between time and training condition were analyzed further with a Johnson-Neyman procedure to reveal the area where the difference between groups was significant. The effect of RAN and initial level of reading speed in the training result was analyzed with a linear regression model. 


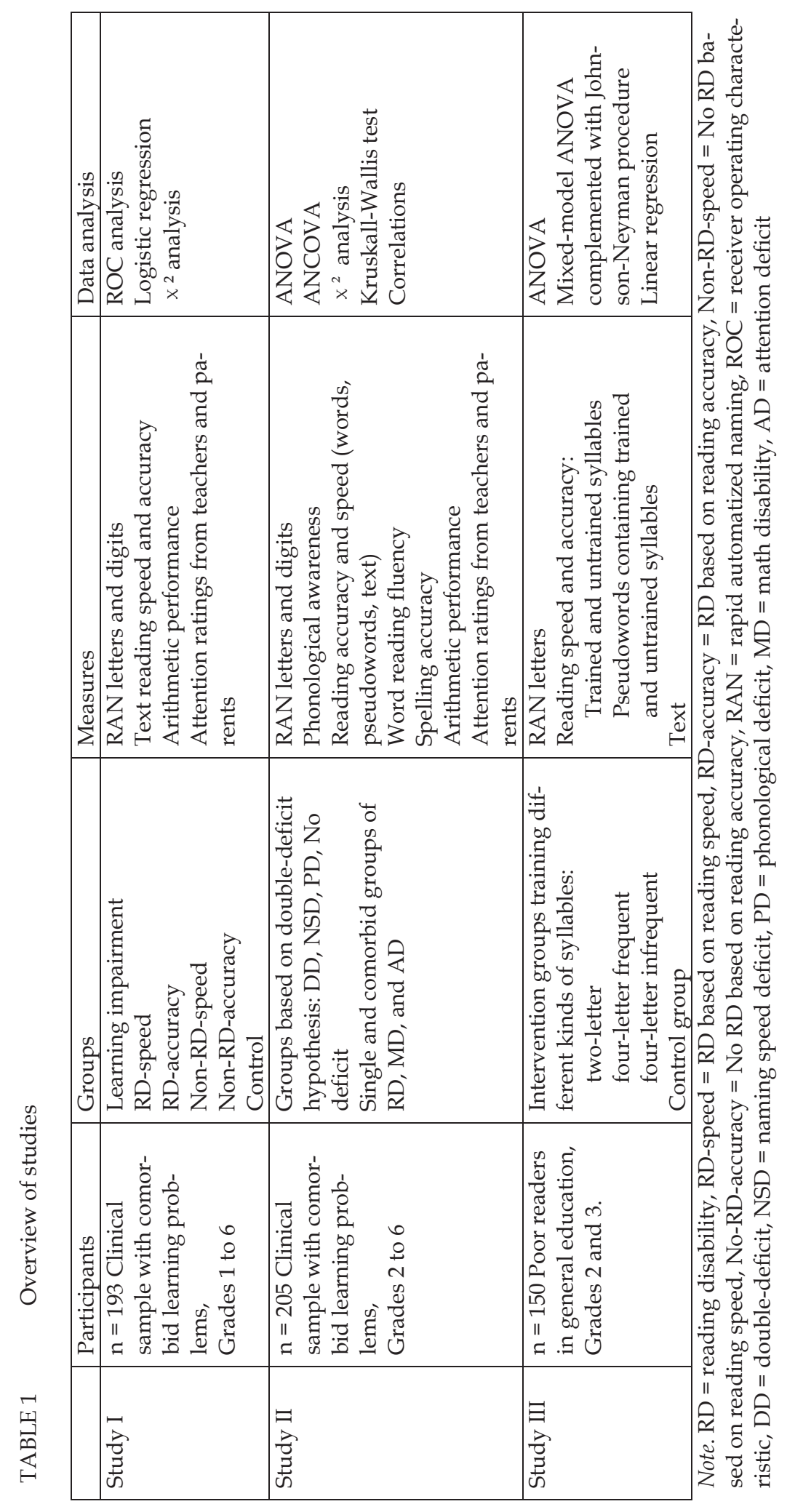




\section{OVERVIEW OF THE ORIGINAL STUDIES}

\subsection{Study 1: Rapid automatized naming and learning disabilities: Does RAN have a specific connection to reading or not?}

This study was a replication of a study originally conducted by Waber et al. (2000), who found that rapid automatized naming (RAN) detected learning impairments in general but was not as effective in discriminating between RD children and children with other learning difficulties. They also found that the prevalence of naming speed deficits increased with the number of comorbid learning difficulties. Based on these results, the authors questioned the specific connection between RAN and reading disabilities. The aim of this study was to explore the findings of Waber et al. with another clinical sample and in different language to see if RAN was an indicator of learning impairments in general rather than connected specifically with reading disabilities.

The participants were 193 children referred to a child neuropsychological clinic because of learning impairments (LI) and a control group $(n=119)$. The children with learning impairments were divided into groups based on their reading disability (RD) status defined separately by speed and accuracy of text reading. To test the ability of RAN to discriminate between different dichotomous groups, a receiver operating characteristic (ROC) analysis was conducted with RAN as a continuous measure. The groups were contrasted in a pairwise manner in the ROC analysis: LI (whole group) vs. Control, RD vs. Control, nonRD vs. Control, and RD vs. non-RD. Each comparison was conducted with two separate definitions for RD: for RD defined as speed and RD defined as accuracy. The comorbidity of learning impairments was explored by forming groups with single or comorbid deficits in reading, math, and attention. The prevalence of naming speed deficit was then detected in each of these groups to see if this prevalence was higher in the groups with higher comorbidity.

The results showed that RAN was at its best in discriminating between RD and the Control group on both definitions of RD. It also discriminated reliably between LI vs. Control and RD vs. Non-RD when RD was defined as reading 
speed. Thus the results confirmed the stronger connection previously found between RAN and reading speed than between RAN and reading accuracy. The prevalence of naming speed deficits did not seem to increase along with the comorbidity of learning impairments. Instead, the prevalence of naming speed deficits was higher in the LI groups with RD (59-89\%) than in those without RD $(26-30 \%)$. This was in contrast with the results of Waber et al. (2000), where the prevalence of naming speed deficits increased with the number of diagnoses regardless of the type of diagnosis.

It was concluded that, in a clinical sample, RAN was more strongly connected with reading disabilities than with other learning problems. The reasons discussed for the discrepancy between our findings and those of Waber et al. included methodological considerations and differences between the samples used in the studies. These results highlighted the need for more replications on the connections of RAN with various cognitive and academic skills. Together, these results suggest that both reading speed and comorbid learning problems should be taken into account when evaluating the factors underlying learning difficulties.

\subsection{Study 2: The double-deficit hypothesis in a clinical sample: extension beyond reading.}

The aim of this study was to explore the double-deficit hypothesis (DDH) in a clinical sample including deficits in reading (RD), math, and attention. The DDH posits that there are two independent deficits underlying dyslexia, namely naming speed deficit and phonological deficit. Overlap between these deficits (double-deficit) is assumed to result in the most severe reading disabilities. It was also examined whether double-deficit or single naming speed deficit and phonological deficit were unique to reading or whether they were also connected with math disability and attention deficit, as suggested in some previous studies.

A sample of children referred to a child neuropsychological clinic for an evaluation of learning difficulties $(n=205)$ was divided in groups based on DDH: double-deficit, naming speed deficit only, phonological deficit only, and no deficit. Reading speed and accuracy, spelling, math performance and attention ratings as well as the prevalence of $\mathrm{RD}$, math disability, and attention deficit were compared between the DDH groups. To explore if the prevalence of double-deficit, phonological deficit, or naming speed deficit was greater with more comorbid learning problems, groups of different combinations of single and comorbid RD, math disability, and attention deficit were cross-tabulated with the DDH groups.

The results supported the DDH in many respects: 1) rapid automatized naming (RAN) and phonological awareness were uniquely connected with reading disabilities: RAN was connected in particular with reading speed and 
phonological awareness with reading and spelling accuracy; 2) deficits in RAN or phonological awareness were closely connected with RD, as $90 \%$ of the children with RD also had double-deficit, naming speed deficit, or phonological deficit; 3) RD was at its most severe and was also most prevalent in the group with double-deficit. However, single deficits in RAN or phonological awareness differed from each other and from the no-deficit group in spelling but not in the reading measures. The results also suggested that naming speed deficit and phonological deficit were specific to RDs and not associated with math disability or attention deficit, as 1) the DDH groups did not differ from each other in math performance or attention ratings, 2) the prevalence of double-deficit was elevated in groups with RD but not among children with math disability or attention deficit without RD, and 3) RAN and phonological awareness correlated with the reading and spelling measures but not with math or attention.

It was concluded that the DDH was mainly supported in a clinical sample with comorbid learning problems and that phonological deficit and naming speed deficit were specific precursors of reading disabilities, rather than learning difficulties at the more general level. These results were in line with those of several studies where RAN and phonological awareness have been uniquely connected with reading when reading fluency has been included as a measure of reading. It was also hypothesized that the results found may be more manifest in samples with RDs compared to normative samples. These results have a number of practical implications for evaluating reading and other learning difficulties in children. First, as specific indicators of reading disabilities, RAN and phonological awareness provide viable tools for early identification of RDs. Second, as they are uniquely connected with different aspects of reading, RAN and phonological awareness can also yield information useful in designing reading intervention. Finally, although RAN and phonological awareness were not connected with math disability or attention deficit in this study, the comorbidity of RD, math disability, and attention deficit should be acknowledged in planning intervention programs, as overlap between these disabilities was high and because comorbid disorders may require different kinds of emphasis for an intervention to be successful.

\subsection{Study 3: Does training in syllable recognition improve reading speed? A computer-based trial with poor readers from second and third grade}

In this study, the outcomes of three specific computerized repeated reading interventions on reading speed were reported. Along with the aim of increasing reading speed of the practiced items (syllables) the transfer effect to larger units at the level of words and to general reading speed was explored. A specific question investigated was whether rapid automatized naming (RAN) and the 
level of reading speed measured at the beginning of the intervention influence the training result.

The participants were 150 poor readers attending the second and third grade in general education classes all over Finland. The children were randomly divided into a control group and three intervention groups, each practicing speeded recognition of syllables differing in length (two-letter vs. four-letter syllables) and frequency (long frequent vs. infrequent syllables). The intervention period consisted of ten sessions with in total 50 repetitions of each of the thirty practiced syllables. The child heard a syllable through headphones and was instructed to choose the corresponding written item as quickly as possible from the options presented on the computer screen. Feedback was given on the speed of a correct answer. The intervention took place under the supervision of a class teacher or a special education teacher, but no individual guidance was required. Before and after the intervention, the reading speed and accuracy of the practiced and unpracticed syllables, the pseudowords including these syllables, and text including very few of the practiced syllables were measured. RAN was measured before the beginning of the intervention.

The results showed that all three training groups improved their reading speed of the practiced items significantly more than the training group. However, for short syllables a significant effect emerged only for $25 \%$ of the children assessed as the slowest readers in the pre-training measures, whereas for long (frequent and infrequent) syllables a significant effect was found for roughly $75 \%$ of the children. An effect was observed for the frequency of the items: more frequent syllables were read more quickly before the beginning of the training while during the training greater gains were made with infrequent syllables.

When the transfer and generalization effects were studied, the training effects were found to be item-specific, as reading speed increased in the trained but not in the untrained syllables. As expected, there was no effect on general text reading speed. Also, as expected, a trend towards a word-level transfer effect was observed in pseudo-words containing the practiced syllables. However, this transfer effect, which emerged after a training period of one to two hours, was significant only for infrequent syllables, where the training effect was strongest. RAN was associated with reading speed measured before the intervention but was not related to the training effect. Initial reading speed, instead, predicted the training effect in short but not long syllables, which meant that the slowest readers gained the most during the intervention.

It was concluded that in a transparent language with a clear syllable structure the computerized syllable-training program served as a promising tool for increasing the reading speed for poor readers just after the initial phases of reading development. With such a short training period we were not able to show strong transfer effects to the word level, which obviously would be necessary for promoting everyday reading fluency. Possible reasons, including the training method and methods for measuring the training effects, were discussed. A need for more explicit support for transfer in training where sublexical items are practiced was highlighted. A positive result for practitioners 
was that slow reading and slow naming did not have negative effects on the training results. These results lend support to the usefulness of an early intervention for reading speed and fluency. 


\section{DISCUSSION}

The present researh focused on the connections between rapid automatized naming (RAN) and reading skills, reading intervention, and comorbid learning problems. Although RAN has been at the center of reading research for the past four decades, a consensus continues to be lacking on a number of issues. In the majority of studies, RAN has been associated with reading fluency, or reading speed, as was also found in this research. However, studies extending the perspective from reading to other skill areas have been rare despite general agreement that RAN is multi-componential in nature, clearly consisting of sub-skills tapping a wide range of skills in addition to reading. The present research contributes to the literature with findings on three aspects of RAN and its associations with other variables. First, the association between RAN, reading, math and attention was studied with the aim of clarifying whether RAN is uniquely connected with reading or has connections with math or attention, as some studies have suggested. In addition, it was explored whether a theoretical model of the impacts of skills underlying reading (the double-deficit hypothesis, DDH; Wolf \& Bowers, 1999) also applies in a sample of children with learning difficulties and, if so, whether comorbidity has confounding effects on the results of applying the DDH. This was the first research to explore these questions, taking all three variables (reading, math, and attention) into consideration concurrently and acknowledging both accuracy and rate of reading performance, in a language with a transparent orthography (Studies I and II). Second, the majority of the previous studies have been conducted at the beginning phase of reading instruction (first and second grade) when decoding skill is still in the process of development. In Studies I and II, the age group studied extended beyond the first two grades, revealing the connection between RAN and reading during a phase in which decoding accuracy has usually been acquired in transparent orthographies and when the variation in reading ability primarily concerns reading fluency or reading rate. In addition, when a younger age group was examined in Study III, reading speed was also the main source of variation in reading ability, as only the children with adequate reading accuracy were included in the study. Finally, the effect of RAN on a reading fluency interven- 
tion was explored among children with poor reading skill (Study III). In many previous studies, the contribution of RAN to the training effect has been studied without controlling for reading level, which was done in this study. In sum, the results of this research extend the literature on RAN by controlling for comorbid learning difficulties, different aspects of reading (accuracy, rate), and exploring RAN in a transparent orthography beyond the primary phases of reading development.

The findings of this research were consistent with previous results where RAN has shown to be associated with reading disabilities, rather than learning difficulties in general (e.g., Denckla \& Rudel, 1976; Georgiou, Tziraki et al., 2013; Moll, Göbel, \& Snowling, 2014; Willburger et al., 2008; Willcutt, Betjemann et al., 2010; Willcutt et al., 2013; Wise et al., 2008). RAN predicted reading skills independently of phonological awareness, and was uniquely associated with reading speed, which is in line with the DDH and several results from studies investigating various orthographies (Wolf \& Bowers, 1999; for reviews, see Georgiou \& Parrila, 2013; Kirby et al., 2010; Norton \& Wolf, 2012). RAN was also associated with pre-intervention reading speed, but had no additional effect on the training effect of the reading fluency intervention when reading level was controlled for. These results strengthen the position of RAN as a predictor and correlate of reading speed after the initial phases of reading development also in samples with variety of learning difficulties in addition to reading disability (RD). Although naming speed deficits and dysfluency in reading seem to be long-lasting, the results of this study indicate that reading fluency is not resistant to intervention despite the presence of naming speed deficit.

\subsection{RAN in the field of academic difficulties and cognitive skills}

The results of Studies I and II, derived from two separate clinical samples of children with learning difficulties, showed that RAN was more strongly associated with RD than other learning difficulties (math disability and attention deficits). The specific connection between RAN and RD was supported by several findings. First, RAN reliably differentiated children with RD from controls and from children with other learning impairments (learning difficulties without RD, LD-noRD) in Study I. This was especially apparent when RD was defined on the basis of reading speed. These results are in line with previous studies where children with RD have performed significantly slower in RAN than controls (de Jong \& van der Leij, 2003; Denckla \& Rudel, 1976; Waber et al., 2000; Wolf, 1986) and also slower than children with other learning disabilities (Denckla \& Rudel, 1976; Denckla, Rudel, \& Broman, 1981; Willburger et al., 2008) and attention deficits (Ackerman \& Dykman, 1993; Boada et al., 2012; Felton \& Wood, 1989; Felton et al., 1987; Närhi \& Ahonen, 1995; Raberger \& Wimmer, 2003; Semrud-Clikeman et al., 2000; Willcutt, Betjemann, et al., 2010) in RAN performance. Second, the prevalence of naming speed deficits was significantly higher in the RD group than in other groups (LD-noRD, Control) in Study I. 
Although this was not directly analyzed in Study II, the same results were obtained from the information available (Table 3 in Study II), as the prevalence of naming speed deficit was higher $(73 \%)$ in the groups with RD than groups without RD (49\%). Third, RAN showed a significant correlation with the reading measures but not with math performance or attention ratings (Study II). In addition, the groups formed according to the DDH differed from each other in reading and spelling performance, but not in math performance or attention ratings (Study II). Fourth, although higher comorbidity in groups with doubledeficit has been suggested in some studies (Torppa et al., 2013; Waber et al. 2004), this was not evident in Study II. double-deficit was associated with the existence of $\mathrm{RD}$, and not with comorbidity per se, as while the prevalence of RDs was elevated in the double-deficit group, no difference emerged between the DDH groups in the prevalence of math disability or attention deficit. In sum, the results from Studies I and II were in line with those of previous studies where RAN has been linked with reading but not specifically to performance in math or attention (Denckla \& Rudel, 1976; Durand et al., 2005; Fletcher, 2005; Georgiou, Tziraki et al., 2013; Landerl et al., 2009; Moll, Göbel, \& Snowling, 2014; van der Sluis et al., 2004; Willburger et al., 2008; Willcutt, Betjemann et al., 2010; Willcutt et al., 2013; Wise et al., 2008).

The results of this research are in conflict with previous findings in which RAN has been associated with math performance (Ackerman et al., 2001; Koponen et al., 2007; Koponen et al., 2013; Murphy, Mazzocco, Hanich, \& Early, 2007; van Bergen et al., 2014; van der Sluis et al., 2004) or with attention deficits (Arnett et al., 2012; Hynd et al., 1991; Tannock et al., 2000; Thomson et al., 2005). There are several possible explanations for this. First, because reading fluency has not been controlled for in many of these studies, the link between RAN and math or attention may in fact be mediated via reading fluency. This notion is supported by studies where children with math disability did not differ from controls in RAN when children with reading fluency problems had been excluded from the math disability group (Landerl et al., 2009; van der Sluis et al., 2004). Accordingly, no association between RAN and attention has emerged when reading skill has been controlled (Ackerman \& Dykman, 1993; Felton \& Wood, 1989; Raberger \& Wimmer, 2003; Semrud-Clikeman et al., 2000; for reviews, see Boada et al., 2012; Miranda, Presentación, Siegenthaler, Colomer, \& Pinto, 2011).

One additional reason for the conflicting results on the association between RAN and attention may be that the inclusion of children with impulsivity and hyperactivity among those with attention deficits may decrease the association between RAN and attention (Arnett et al., 2012; Hynd et al., 1991; Thomson et al., 2005). Another explanation may relate to the tasks used as the measure of RAN. Several results suggest that the alphanumeric items such as those used in this research are more strongly associated with reading (for reviews, see Araújo et al., 2014; Georgiou \& Parrila, 2013) whereas nonalphanumeric items may have more components in common with attention (Carte, Nigg, \& Hinshaw, 1996; Rucklidge \& Tannock, 2002; Semrud-Clikeman 
et al., 2000; Stringer et al., 2004; Tannock et al., 2000). These three factors may explain most of the contrasting results concerning attention. However, the results pertaining to math are not as clear-cut: in contrast with the results of this research, some studies have found a connection between RAN and math even after controlling for reading fluency (Koponen et al., 2013; van Bergen et al., 2014). One explanation that may partly resolve this discrepancy derives from the composition of the samples studied. The results of Koponen et al. (2013) showed a significant connection between RAN and math in a sample with typical reading skill while no connection between RAN and math was found for a group with RD. The same result emerged in the samples studied by van Bergen et al. (2014; E. van Bergen, personal communication, June 20, 2014). It could be argued that this is a statistical artifact, since the variation in the association between RAN and reading may be restricted in samples representing the end of the continuum. However, this is not always the case, as sometimes RD groups have shown wider variation than normative groups (Torppa et al., 2012; M. Torppa, personal communication, June 30, 2014). In any case, sample selection is one of the parameters to be noticed in interpreting the results as, for example, the present study consisted of children with a high prevalence of RD.

Third, the age of the participants may also have an effect on the result, as the connection between RAN and math performance appears to decline along with the development (Hecht, Torgesen, Wagner, \& Rashotte, 2001; Mazzocco \& Grimm, 2013). This may partly derive from the changing requirements of the math tasks: at the beginning of schooling tasks often rely more on skills requiring fluency of fact retrieval (counting, addition, and multiplication with singledigits; Moll, Göbel \& Snowling, 2014) with calculation strategies receiving more emphasis later on. Of these two learning phases, RAN is thought to be more strongly associated with arithmetic fact retrieval (e.g., Hecht et al., 2001; Koponen et al., 2007; Krajewski \& Schneider, 2009) than with more complicated calculation tasks (Hecht et al., 2001; Koponen et al., 2007, 2013). The task used for the assessment of math skills in this research consists of a mixture of single- and multi-digit calculations covering all the basic arithmetical operations; this choice of task may in part explain why the connection between RAN and math was modest in the present research.

In addition to the explanations presented above, the increased comorbidity of learning difficulties may also be linked to other factors such as processing speed (McGrath et al., 2011; Willcutt, Betjemann et al., 2010; for review, see Boada et al., 2012) or short-term memory (Jacobson et al., 2011; Landerl et al., 2009; Willcutt et al., 2013) that were not controlled for in the study by Torppa et al. (2013) or in this research. These additional predictors clearly need to be included in further studies exploring reading skills in samples with comorbid learning disabilities or behavioral problems. In sum, one of the main findings of this research was that RAN had no unique connection with math performance or attention ratings over and above that with reading skills, where it was associated in particular with reading performance, especially reading fluency. 
The results found here have several theoretical and practical implications. To begin with, the connection previously found between RAN and math or RAN and attention seems to be mediated by reading fluency or rate. Therefore, reading fluency is one of the most important variables to be controlled for in studies exploring the connection between RAN and academic difficulties. Other variables that may explain the varying findings concerning the connection between RAN and math are the age of the participants, the tasks used for assessing math, and the composition of the sample (i.e., an RD or a normative sample). In assessing the relation between RAN and attention, the RAN measure used (alphanumeric, non-alphanumeric) and the subtype of attention deficit should also be acknowledged, as RAN has proven to be associated with inattention rather than impulsivity or hyperactivity (Arnett et al., 2012; Hynd et al., 1991; Thomson et al., 2005). In addition, from the practical and clinical point of view the results of RAN in the assessment of learning difficulties should be interpreted primarily in connection with reading and other measures rather than as indicators pure and simple of math and attention deficits. This is not to say that RAN should be used as a diagnostic measure for RDs either, as suggested by some scholars (Carver, 1991; Davis \& Spring, 1990), since more effective print-based diagnostic tests are both available and more effective than RAN in discriminating good and poor readers at school age (Hammill, 2004; Hammill et al., 2002), and RAN as a discriminator appears to over-estimate the proportion of poor readers (Georgiou, Parrila, Manolitsis, \& Kirby, 2011). Instead, RAN could be used as an indicator of reading difficulties before literacy-based measures can be used (i.e., before reading instruction; De Jong \& van der Leij, 2003; Lervåg \& Hulme, 2009; Puolakanaho et al., 2007; Reiter, 2001; Wolf et al., 2000), and as one of the tools for exploring the background of reading skills more thoroughly (Hammill, 2004).

The results of this research have also some implications for the theories on the cognitive correlates of RAN. Although RAN clearly represents a wide variety of skills, the present findings of no specific connection to math or attention indirectly support the notion that it is linguistic components that are highlighted in RAN performance. If RAN performance was primarily explained by processing speed, RAN would probably be associated more closely with attention and math than it was, because processing speed has been found to be one of the factors shared by RD, math disability, and attention deficit (Boada et al., 2012; Compton, Fuchs, Fuchs, Lambert, \& Hamlett, 2012; McGrath et al., 2011; Willcutt, Betjemann et al., 2010; Willcutt, Pennington, et al., 2010; Willcutt et al., 2013). If, instead, RAN was characterized by short-term memory of working memory, a stronger connection between RAN and math would have been expected, as short-term memory is thought to be especially associated with math performance (for reviews, see Raghubar, Barnes, \& Hecht, 2010; Swanson, Jerman, \& Zheng, 2009) and short-term memory is acknowledged to be a factor common to RD and math disability (Landerl et al., 2009; Willcutt et al., 2013). It has also been suggested that along with the linguistic domain, executive functions are tapped in RAN performance (Denckla \& Cutting, 1999). If so, RAN 
would be expected to be associated with attention skills, as these are closely associated with executive functions (Gooch, Snowling, \& Hulme, 2011). Although we did not explore this directly, the finding that RAN was not associated with attention does not support this view. In sum, while we acknowledge that RAN taps a variety of skills, including for instance processing speed, motoric and linguisitc fluency, working memory, and possibly executive functions (e.g., Närhi et al., 2005), our results highlight the linguistic domain in RAN performance, relating it more closely to reading than other academic domains or attention. Given the high comorbidity of RD, math disability, and attention deficit in the clinical samples investigated in this research, other candidates besides RAN (or phonological awareness, Study II) should be explored. The literature shows that the most likely candidates to explain the comorbidity of $\mathrm{RD}$, math disability, and attention deficit include processing speed (Boada et al., 2012; Compton et al., 2012; McGrath et al., 2011; Miranda et al., 2011; Willcutt, Betjemann et al., 2010; Willcutt, Pennington et al., 2010; Willcutt et al., 2013) and short-term memory (Jacobson et al., 2011; Landerl et al., 2009; Willcutt et al., 2013).

Finally, the high comorbidity between RD, math disability, and attention deficit found in the present research $(64 \%$ of the children in Study I and $57 \%$ of the children in Study II had more than one learning difficulty), implies that the fact that these difficulties co-occur so often should also be acknowledged in the assessment of reading disabilities (see also DuPaul et al., 2013). The comorbidity of learning difficulties should be especially acknowledged in planning reading interventions, since different combinations of learning difficulties may respond to intervention in different ways (Boada et al., 2012; Fuchs et al., 2013), and intervention for RD may be enhanced by adding elements targeting additional deficits, such as attention deficit (Aro, Ahonen, Tolvanen, Lyytinen, \& de Barra, 1999; for a review, see Sexton et al., 2012).

\subsection{RAN and reading in a transparent orthography}

The above-presented conclusions that RAN is more strongly associated with reading disabilities and the linguistic domain than with other learning difficulties and the non-linguistic domain warrant further exploration. What has this research to say on such questions as: How is RAN connected with reading? Or which linguistic skills are associated with RAN and which are not? First, the results of this research support those of previous studies reporting that after the first phases of reading, RAN is specifically associated with reading speed and fluency, and less strongly with reading accuracy or spelling (e.g., Compton et al., 2001; Furnes \& Samuelsson, 2011; Papadopoulos et al., 2009; Pennington et al., 2001; Schatschneider et al., 2002). Why the present association between RAN and reading accuracy is lower than reported in some previous studies (e.g., Cornwall, 1992; Cutting \& Denckla, 2001; Manis et al., 1999; Schatschneider et al., 2004) derives from the features of the orthography and the phase of reading 
development studied. In transparent orthographies, such as Finnish, the development of reading accuracy reaches its ceiling comparatively fast (Seymour et al., 2003), after which RAN appears to be more strongly connected with reading fluency (e.g., Georgiou et al., 2006, 2009; Vaessen \& Blomert, 2010). The participants in the present research were for the most part children who had already passed the first phases of reading, and whose reading accuracy was relatively high despite the high representation of reading disabilities in the sample. Therefore, the larger part of the variation in reading fluency was due to reading speed, for which RAN was the strongest correlate. Thus, the results of this research support the use of RAN as an indicator of deficits in reading fluency in children with reading and learning difficulties.

The results of Study II support the double-deficit hypothesis (DDH) of dyslexia (Wolf \& Bowers, 1999) in many respects. First, the group with doubledeficit (i.e., deficit in both RAN and phonological awareness) performed significantly worse in all the reading measures (accuracy, rate, and fluency) than the other groups. In addition, the prevalence of RD was greatest in the doubledeficit group, and also greater in the single-deficit groups than no-deficit group. Additional support for the DDH comes from the finding that RAN was not very strongly associated with phonological awareness. RAN and phonological awareness were linked with unique aspects of literacy: RAN was associated most strongly with reading speed and reading fluency whereas phonological awareness was connected with reading and spelling accuracy. These results are in line with those of previous studies in which the DDH has been supported in various orthographies (for the most recent reviews, see Georgiou \& Parrila, 2013; Kirby et al., 2010; Norton \& Wolf, 2012) and separate roles indicated for RAN and phonological awareness in predicting literacy skills (Compton et al., 2001; Cornwall, 1992; Furnes \& Samuelsson, 2011; Kairaluoma et al., 2013; Moll, Ramus et al., 2014; Papadopoulos et al., 2009; Pennington et al., 2001; Schatschneider et al., 2002; Sunseth \& Bowers, 2002; Torppa et al., 2012; Vaessen et al. 2009, 2010; Wimmer et al., 2000). However, the result that the single-deficit groups did not differ from the No deficit group in the reading measures was not an expected outcome according to the DDH. The fact that the No deficit group had a relatively high prevalence of reading disabilities (53\%), even without deficits in phonological awareness or RAN, would lead us to expect other variables (e.g., cognitive, behavioral, motivational, mental) in addition to phonological awareness and RAN to account for the variance in reading skills in clinical samples such as those in the present research. This possibility should be investigated in further studies on clinical samples, where comorbid problems also often exist.

This research did not explore the relation between RAN and linguistic skills such as orthographic knowledge or short-term memory. However, the results of Study II have relevance for the debate on whether RAN is a component of phonological skills or not. First of all, this question is in part merely one of definition and categorization: How do we define phonological skills, and do we assign the skill of efficiently retrieving the names of familiar items from 
long-term memory (RAN) to the family of phonological skills or not? For example, Wagner et al. (1997; see also Kibby et al., 2014) subsume RAN under the heading of phonological processing skills, which include phonological naming (RAN), phonological awareness, and phonological memory (i.e., short-term memory). Both sides of the debate suggest that RAN is associated with rate or efficiency in naming items, and thus these viewpoints are not necessarily in conflict (Gasperini et al., 2014). Where the two sides diverge is in whether they see RAN as separate from phonological awareness or not (compare the results supporting the DDH vs. those of, e.g., Torgesen et al., 1997). Based on the results of the present Study II, they seem to be separate, at least in this phase of reading development (second to sixth grade), as the association between RAN and phonological awareness was modest and they predicted different aspects of literacy. As the results of Parrila et al. (2004) show, RAN and phonological awareness increasingly diverge from each other during reading development. Therefore the age and the phase of reading development of the participants should be taken into account when interpreting results on the relation between RAN and phonological awareness. The practical implications of the present result that RAN and phonological awareness are separate in predicting reading skills are that both should be taken into account when assessing reading skills, with the emphasis on reading speed in transparent orthographies, as is already done by most scholars. The results have implications for RD interventions: knowing the background of reading difficulties (RAN, phonological awareness, but also other predictors, such as familial risk for reading difficulties, letter knowledge, short-term memory etc.) also helps in targeting the intervention. If naming speed deficits are found, the most relevant target for intervention would most probably be the automatization of reading skills towards fluency (discussed later). However, these results do not allow a stand to be taken on many of the aspects of this discussion, such as the biological basis of phonological awareness and RAN, the stability of the relations between these skills, or the results of interventions that include a set of phonological skills as predictors these are topics for future studies.

The results of this research support the view that RAN, along with phonological awareness, is a predictor and a correlate of reading disabilities. In Study I, RAN was able accurately to discriminate $78 \%$ of the RD children from controls when RD was defined as reading speed. In Study II, $90 \%$ of the children with RD had either a single or double-deficit in RAN or phonological awareness, which suggest that these factors detect the majority of children with RDs. However, as suggested earlier, RAN seems to be as its best as a predictor and as an indicator of reading fluency difficulties, not as a diagnostic tool. The specificity (i.e., true negative rate) for RAN in discriminating children with RD from children with no RD was, at its best, $77 \%$, while sensitivity (i.e., true positive rate) in this same analysis was $79 \%$. These figures exceed the limit of .75 suggested for a successful outcome value (Hammil et al., 2002), but as more efficient print-based diagnostic tools for school-aged children are available, RAN should be used as one tool among others in the package of assessment tools. In 
addition, when interpreting the results of this research, it should be noted that the participants were children with a high prevalence of reading disabilities. It is possible that the measures used here behave differently among children with $\mathrm{RD}$ and those in a normative sample. RAN may be more strongly correlated with reading skills in a sample of poor readers (Allor, 2002; Araújo et al., 2011; Cardoso-Martins \& Pennington, 2004; Hammill et al., 2002; McBride-Chang \& Manis 1996; Meyer et al., 1998; Pennington et al., 2001; Scarborough 1998; Wolf \& Bowers, 1999), while the same is suggested for phonological awareness (Schatschneider et al., 2002). In addition, Torppa et al. (2013) showed that a larger set of variables predicted reading skills in the No deficit group than in the double-deficit group, in which reading difficulties were more strongly represented. Therefore, using RAN alone as a screening instrument for reading difficulties in representative samples should be done with caution. In previous studies on a longitudinal Finnish sample (Jyväskylä Longitudinal Study of Dyslexia), RAN accompanied with other cognitive predictors (letter knowledge, phonological awareness, short-term memory, IQ), and familial risk for reading disabilities (Eklund, Torppa, \& Lyytinen, 2013; Puolakanaho et al., 2007; 2008; Torppa et al., 2010) seemed to increase the reliability of the prediction of reading disabilities. In addition, RAN appears to have specific utility in predicting reading difficulties in transparent orthographies and should, therefore, be included as one of the tools in reading assessment (Georgiou et al., 2011).

In conclusion, the results of this research link RAN with, in particular, reading speed and fluency in samples in which reading disabilities are highly represented. The association between RAN and reading accuracy was modest, and no connection was found between RAN and spelling. Based on the results of this research, RAN is independent of phonological awareness in predicting reading skills. RAN was a rather reliable discriminator between children with and without reading speed deficits, but seemed not to be sufficient to predict all reading difficulties. The result that a vast majority of the children with RD were characterized by deficits in RAN, phonological awareness, or both for the most part supported the DDH (Wolf \& Bowers, 1999) and also gave indirect support for the multiple deficit model of developmental disorders (Pennington, 2006), although, to throw further light on the precursors of learning difficulties, more potential predictors should be included. The result of the specific connection between RAN and reading fluency should also be acknowledged in planning interventions for reading difficulties, especially in transparent languages where reading disabilities are most typically manifested as dysfluent reading.

\subsection{On the reading intervention and RAN}

Study III explored the effect of repeated recognition of sub-lexical items (syllables) on reading fluency and the contribution of RAN to the intervention effect among children with poor reading skill. This study replicated the findings of a previous study where repeated reading of syllables had transferred also to 
word-level reading fluency (Huemer et al., 2010). This study extended the study by Huemer et al. (2010) by comparing the training effect in syllables differing in frequency and in length and by exploring the training effect on computerized training. Controlling for the initial reading level, the effect of RAN on gains in reading fluency was also explored.

The first set of results concerned the effects of repeated syllable training. The reading fluency in the trained syllables (i.e., short syllables, long frequent syllables and long infrequent syllables) increased in all the training groups compared to the control group, which indicated that significant training effects can be achieved with a rather short period (one-to-two-hour) of intensive, targeted training. The characteristics of the trained material had an impact on the training results: the gains varied by the frequency and length of the syllables trained, with a stronger training effect found for the more infrequent and longer items. The choice of frequent syllables was based on assumptions regarding previous exposure to these items, as the automatization process was assumed to have already begun with the more frequent syllables whereas in the case of infrequent syllables the training effect was assumed to reflect the effect for acquaintance with practically novel items. This assumption was supported by results prior to training that showed that frequent syllables were read significantly faster than infrequent syllables, when matched for length and syllable structure, thereby confirming the syllable frequency effect also found in previous studies (Perea \& Carreiras, 1998). In accordance with the results of previous studies, where most gains in reading fluency have been reached during the first exposures (Lemoine, Levy, \& Hutchinson, 1993; Meyer \& Felton, 1999), significantly more gains in reading fluency was found for the infrequent items, these gains almost equalling the post-intervention reading speed of frequent syllables. The second result, showing more gains in long syllables versus short syllables matched in frequency should not, theoretically, be due to previous exposure but merely to stronger automatization and the greater decrease in the effect of length (Maloney, Risko, O'Malley, \& Besner, 2009) for these longer syllables, in turn reflecting a shift from serial letter-by-letter processing towards recognition of the whole unit. These results are promising, as significant gains were reached in all the trained items, while they also reflect the need for careful selection of the items to promote the best possible increase in reading speed. Practicing short syllables may be more effective in the first phases of the automatization process but, as shown in this study, the training effect for these items was only significant for the poorest quarter of the second and third graders, all considered poor readers, participating in this study. However, the fact that the greatest gains were made in the speed of reading infrequent syllables does not necessarily mean that these are the most beneficial items to practice from the standpoint of everyday reading, as they more seldom occur in everyday texts. Therefore, a balance between the training effects found on the sub-lexical level and the presumed transfer effects to everyday reading discussed below should be found when planning fluency training in sub-lexical items. 
The training effects were item-specific, a result that has previously been found in repeated reading training (Berends \& Reitsma, 2006; Lemoine et al., 1993; Marinus et al., 2012; Thaler et al., 2004). The transfer effect from syllables to the word level (pseudowords containing the practiced items) was statistically significant for long infrequent syllables, where the training effect was strongest, replicating the findings of Huemer et al. (2010). Despite the same trend for frequent syllables, the transfer effect to the word level did not reach significance after the short training period. However, regardless of smaller effects in training and transfer, a focus on more frequent syllables may promote proportionally greater effects in everyday reading, as these items occur more often in texts likely to be encountered.

In the context of the larger picture, the ultimate goal of sub-lexical repeated reading training is to promote reading comprehension. Several studies have shown a causal (Kim, Petscher, Schatschneider, \& Foorman, 2010; Wise et al., 2010) or bidirectional (Klauda \& Guthrie, 2008) link between reading fluency and reading comprehension. In addition, even small gains in reading fluency have in some studies benefited reading comprehension (Breznitz, 2006; however, see Soriano et al, 2011). Thus, for sub-lexical fluency training to have positive effects on reading comprehension, multiple transfer effects need to be demonstrated from sub-lexical items to word-level, and via words to text-level, reading fluency. In this study, the training program did not directly promote such a transfer effect. In further studies and in practical applications, word- and textlevel transfer should be among the targets of this kind of training. Combining fluency training with reading comprehension would most probably be the most efficient way to support functional reading skills (Norton \& Wolf, 2012; Steacy et al., 2014).

In Study III, the individuals showing the greatest training effects in reading fluency were the ones with the slowest pre-training reading speed. This is a promising result, showing that the poorest readers were not as resistant to intervention as sometimes reported (Berninger et al., 2002). However, this result may also be criticized as the more fluent readers of this sample, who made less progress than the poorest readers, may have already reached their asymptote of reading speed (Breznitz, 2006) and therefore had little room for improvement This argument seems plausible as the average reading speed of the fastest readers in this sample approached close to that of a normative sample (Torppa et al., 2010). Although only the poorest readers were able to increase their reading speed of the short syllables, the majority of the children showed significant training effects in their reading speed of the long syllables. Again, this highlights the need to target reading training at items that are not yet automatized. At the same time, it is important to acknowledge the item-specificity of the training and promote word-level transfer by choosing items that are relevant for everyday reading.

The second major result in Study III concerned the role of RAN in predicting the training outcome. The results showed that RAN was associated with pre-intervention reading speed, as was expected on the basis of previous stud- 
ies (Holopainen et al., 2001; Lervåg \& Hulme, 2009; Savage \& Frederickson, 2005), but not with the training effect after controlling for pre-training reading speed. This result was also in line with previous findings, where RAN has not affected the training result after controlling for reading level (Berends \& Reitsma, 2006; Levy et al., 1997). Thus, in this study slow readers with naming speed deficits were not as resistant to intervention as has previously been suggested (Compton, 2000; Stage et al., 2003). However, the content of the intervention may alter the effect of RAN on the training result: in word-level training children with slow naming speed have progressed more poorly (Levy et al., 1999); however, this has not been the case in training of text reading fluency (Levy et al., 1997). Thus, to clarify the role of RAN on reading fluency intervention requires studies exploring the interaction between reading level, training content and RAN. An additional result of this study showed that pre-training reading speed predicted the training effect in the short items but not in the long frequent or infrequent items. That is, in the short syllables only the poorest readers showed gains in reading speed whereas in the long syllables the majority of the sample progressed regardless of their reading level.

Taken together, these results indicate that repeated recognition of syllables is a promising tool for increasing reading speed in second and third grade Finnish children with poor reading skill independent of naming speed. However, these are only the first steps toward functional reading skill, as this study did not address all the levels of the transfer effects needed to achieve progress in fluent text reading and good reading comprehension, nor did we address reading motivation, which is connected with the amount of independent practice and with the process of becoming a proficient reader (for a review, see Morgan $\&$ Fuchs, 2007). The results of this study indicate that in planning a reading fluency intervention, the initial reading level should be carefully assessed and the items to be practiced chosen on the basis of this information. In light of previous research and suggestions (Lovett, Steinbach, \& Frijters, 2000; Norton \& Wolf, 2012; Steacy et al., 2014; Wolf et al., 2000), reading fluency training is likely to be more efficient when it is multifaceted and the transfer effects between the different levels of reading are explicitly targeted. RAN is one of the predictors of reading speed, and consequently could be assessed as one of the sources of information on the skills underlying reading ability. Yet in targeted, short, and intensive training RAN does not appear to have a significant effect on the training result. However, it remains unclear whether the needs of children with different types of deficits in underlying skills (e.g., in phonological awareness, RAN or both) are similar or different after the first phases of reading (Steacy et al., 2014), and hence further exploration of the effect of interventions targeting these subgroups is needed. In conclusion, while naming and reading speed deficits are persistent in their nature, they seem not to be resistant to intervention. Because young children appear to benefit more from reading intervention (Kirby et al., 2010; Wanzek et al., 2013), early identification, careful planning, accurate targeting of the intervention and multifaceted training in which the unique 
characteristics of the individual child and the orthography are taken into account may prevent the cumulative negative effects of dysfluent reading.

\subsection{Limitations and suggestions for future research}

Reading, math performance, attention, RAN, and phonological awareness are all skills that form a continuum. Therefore, setting cut-offs for identifying groups with disabilities always presents some challenges for the interpretation of the results, as the dichotomization of continuous variables is known to decrease effect sizes, power and measurement reliability (Branum-Martin, Fletcher, \& Stuebing, 2013; Compton et al., 2001; MacCallum, Zhang, Preacher, \& Rucker, 2002; Schatschneider et al., 2002). In Studies I and II, dichotomous categorizations were performed to replicate the previous findings on comorbidity. In these studies, the use of continuous variables would have brought some advantages. In Study I, clarifying the impact of RAN on the continuous measures of reading accuracy and rate with regression methods would have helped to determine the unique effect of RAN on these variables. This would have helped to resolve the problem of overlapping RD groups when defined by reading rate and accuracy. In Study II, regression analyses with continuous variables were conducted to examine the proportion of the variance accounted for by phonological awareness and RAN in the dependent variables (reading performance, spelling, arithmetic, and attention). The results of these analyses paralleled those from the analyses with dichotomous variables and were not reported in the study, as the latter were easier to compare with those of the previous studies on the double-deficit hypothesis. This is not to say that the decisions made here were optimal. I acknowledge that mimicking previous studies in their methods solely for replication purposes is not a good justification for dismissing s more reliable and statistically more efficient method (for examples, see Branum-Martin et al., 2013). That said, part of the problem of confining the analysis to the end of the distribution would remain, even where continuous variables are used, as the majority of the children analyzed in this research represented the end of the continuum in their reading ability. Therefore the results of this study should not be generalized to reading in normative populations but be interpreted in the framework of reading disabilities.

The second obvious limitation of this research is the lack of follow-up measurements of the intervention effects in Study III. As the effects gained during an intervention may be temporary only (Fugate, 1997), follow-up measurements would be revealing on the persistence of the improvements in reading and naming skills. However, expecting far-reaching effects from just a short training period would be comparable to the effects of a short period of physical exercise that produces temporary gains in muscle strength that vanish when the training does not continue. Thus, reading fluency needs not just short training sprints but continuous training to increase. Otherwise the gap between good and poor readers will continue to grow. Study III modelled the progress that 
can be attained during a training program, and offers a training tool that does not require large amounts of professional assistance as resources. The next step would be to implement these methods in a motivating game-like environment, so that continuous training would be both possible and inviting in an every-day environment. As the results of this study showed, to attain the optimal result, the initial reading level should be taken into account in the selection of the training material. Thus, building valid and reliable measures of reading and skills underlying it into reading training programs would optimize the training and facilitate adaptation of the training to the different levels of reading and to the different manifestations of reading problems. These are topics of further research that could help resolve the problem posed by the limited resources available for giving professional help to children with reading disabilities, and so enable a possible break-through in the area of reading intervention. This does not mean that in the near future a computer program would be able to replace the professionals in the field; instead, through being used to increase the number of repetitions needed to promote the automatization of reading, it could be a valuable supplementary tool in a reading intervention that would also release time resources for application in other areas.

There are numerous topics for future research on reading fluency interventions. Although various aspects of literacy were included in this research, it did not include a comprehensive evaluation of math and attention skills. In further studies on the skills underlying comorbidity, these aspects should be taken into account, as using single measures for the identification of a difficulty may elevate the existing comorbidity and thus lead to somewhat biased results (Du Paul et al. 2012). More versatile assessment of math and attention would also provide information on the sub-skills of math and sub-types of attention deficits, which may vary in their association with background skills, as discussed earlier. This study did not include measures that have previously been proposed as common factors behind the comorbidity of RD, math disability, and attention deficit. In future studies, processing speed and short-term memory should be taken into account in studies exploring the comorbidity of learning difficulties. Acquiring more knowledge on the variables affecting on comorbidity has obvious linkages to interventions. Not much is known on what would be specific intervention methods for groups with comorbid learning difficulties. However, the first findings indicate that this information is necessary to find the optimal methods for intervening in comorbidity problems. In addition, information on the factors underlying learning difficulties would enable earlier prediction, and thus prevention, of learning difficulties and their cumulative effects.

\subsection{Conclusions}

Producing new knowledge on reading, on reading intervention and on the skills underlying reading is a challenging task in light of the long history of reading research. However, in some areas exploration has only recently begun, 
and new findings continue to emerge. First, differences between orthographies in reading development and in the manifestation of reading disabilities have been more widely acknowledged for only a decade, and have had the effect of foregrounding the role of reading fluency instead of reading accuracy in transparent orthographies. Second, knowledge of the underlying skills contributing to reading fluency and its components is rather new area of research, producing more eclectic options in the field, such as the double-deficit hypothesis or multiple deficit hypothesis, than single-predictor explanations. However, these views seem to affect the practical decisions made in research slowly, as reading is still very often measured solely as reading accuracy, which effects the associations found between reading and its underlying skills. Third, the body of research on reading fluency interventions has also increased lately, but not much is known on the most effective ways to promote reading fluency. Even less is known on the training methods that take into account the specific features of the target orthography. Finally, while the comorbidity of learning difficulties has been acknowledged for a couple of decades, research on the common factors behind comorbidity has only recently begun. This research taps all these new areas of research in exploring the role of rapid automatized naming (RAN) as a skill underlying reading fluency and reading fluency intervention not only in samples with RD but also in samples with comorbid learning difficulties.

The findings of this research highlight the need to consider the components of reading (accuracy, rate) as separate but correlated entities, where RAN is associated with reading speed and phonological awareness is associated merely with reading and spelling accuracy. As reading accuracy was rather high even in the children with reading disabilities, the emphasis on reading speed as a marker of reading fluency underline the role of RAN as a skill affecting reading after the first phases of reading in Finnish. However, RAN seems not to limit the benefits gained from intensive and targeted training in reading fluency - which is good news for practitioners. What should be taken into account in a reading intervention are the reading level of the children and thus the right level of the training material, the specific features of the orthography trained, support for the generalization of the training results and for motivation, and the comorbidity of learning difficulties. In clinical samples, exploring the comorbidity of learning difficulties is a necessity. As Pennington, Willcutt, and Rhee (2005) have noted, acknowledging comorbidity may influence not only the decisions we make on the diagnosis of $\mathrm{RD}$, on the type of intervention, and on how we understand the underlying mechanisms but also on the conclusions we make on the associations that emerge between variables. The last notion in the context of this study would mean that, without taking reading fluency into account, we would probably find a (false) connection between naming speed deficits and learning difficulties and would not find the (true) connection between reading and RAN, at least of the magnitude revealed in this research. In sum, the results of this research imply that while comorbid learning problems should be taken into consideration in reading assessment and intervention, naming speed deficits indicate deficits specific to reading, in particular reading fluency. 


\section{YHTEENVETO (FINNISH SUMMARY)}

\section{Nopea nimeäminen ja lukemisen sujuvuus oppimisvaikeuslapsilla}

Tämän tutkimuksen keskiössä olivat lukemisen sujuvuus sekä nopea sarjallinen nimeäminen (nopea nimeäminen, nimeämisnopeus, rapid automatized naming, RAN) eli taito hakea sujuvasti mielestä sarjallisessa muodossa esitettyjä tuttuja ärsykkeitä kuten värejä, esineitä, kirjaimia tai numeroita. Tutkimuksen tavoitteena oli selventää nimeämisnopeuden roolia oppimisvaikeuksien ja lukemisen interventioiden näkökulmasta sekä tuottaa nopeasta nimeämisestä ja lukemisen sujuvuudesta tietoa, josta on sekä diagnostista että kliinistä hyötyä. Nimeämisnopeuden ja lukemisen sujuvuuden tutkimus on kielessämme oleellista, sillä aikaisemman tutkimuksen perusteella nimeämisnopeus on vahvimmin yhteydessä juuri lukemisen nopeuteen ja sujuvuuteen. Joidenkin havaintojen mukaan tämä yhteys korostuu suomen kaltaisissa kirjoitusjärjestelmältään säännönmukaisissa kielissä, joissa lukemisvaikeudet näkyvät erityisesti lukemisen sujuvuuden ongelmina. Nykytutkimuksen valossa nimeämisnopeus on kuitenkin monitekijäinen taito, ja vaikka suurin osa siihen liittyvästä tutkimuksesta koskee nimeämisnopeuden yhteyksiä lukemiseen, yhteyksiä myös muihin taitoihin (esim. matematiikan osaamiseen ja tarkkaavuuteen) on havaittu. Tutkimuksia, joihin on sisällytetty lukemisen lisäksi sekä matematiikan että tarkkaavuuden arviointi, on hyvin vähän, ja niistä on saatu keskenään ristiriitaisia tuloksia. Yhtenä mahdollisena syynä on, että useissa tutkimuksissa lukemista on arvioitu ainoastaan tarkkuuden perusteella eikä nimeämisnopeuteen vahvimmin yhteydessä olevaa lukemisen sujuvuutta tai nopeutta ole aina huomioitu.

Tässä tutkimuksessa tarkasteltiin nimeämisnopeuden yhteyttä lukemisen nopeuteen ja tarkkuuteen mutta myös matematiikan ja tarkkaavuuden taitoihin lapsilla, joilla on havaittu oppimisvaikeuksia. Samassa yhteydessä tutkittiin kaksoisvaikeushypoteesin (double-deficit hypothesis) toteutumista kliinisessä aineistossa, johon kuuluvilla lapsilla on oppimisvaikeuksia ja tarkkaavuusongelmia. Hypoteesin mukaan lukemisvaikeuksien taustalla vaikuttavat haasteet nimeämisnopeudessa ja fonologisessa tietoisuudessa toisistaan riippumattomasti. Päällekkäin esiintyessään nämä taustataitojen vaikeudet johtavat yksittäisiä ongelmia haastavampiin lukemisvaikeuksiin. Edellisten kysymysten lisäksi tutkittiin, vaikuttaako nimeämisnopeus lukemisen sujuvuuden harjoittelutuloksiin tois- ja kolmasluokkalaisilla heikoilla lukijoilla. Aikaisempi tutkimus on keskittynyt pääasiassa lukemisen alkuvaiheeseen, joten tämä tutkimus tuo tietoa lukemisen sujuvuuden yhteydestä nimeämisnopeuteen vaiheessa, jossa lukemisen oletetaan automatisoituvan.

Ensimmäisessä osatutkimuksessa tarkasteltiin Waberin ym. (2000) saamia havaintoja, joiden mukaan nimeämisnopeus ennustaa oppimisvaikeuksia yleisesti eikä niinkään erottele lapsia, joilla on lukemisvaikeus, niistä lapsista, joilla on jokin muu oppimisen haaste (matematiikan oppimisvaikeus tai tarkkaavuushäiriö). Waber tutkimusryhmineen havaitsi myös, että nimeämisvaikeuksien määrä on suurempi, jos lapsella on päällekkäisiä oppimisvaikeuksia. Näi- 
den löydösten perusteella kirjoittajat kyseenalaistivat nopean nimeämisen spesifin yhteyden lukemisvaikeuksiin. Tämän tutkimuksen ensimmäisen osatutkimuksen tavoitteena oli toistaa Waberin ym. tutkimus käyttäen suomalaista kliinistä aineistoa ja selvittää, onko nimeämisnopeus yhteydessä erityisesti lukemisvaikeuksiin vai oppimisvaikeuksiin yleisemmin. Tutkimuksen aineisto koostui 8-11-vuotiaista lapsista $(n=193)$, jotka olivat tulleet lastenneuropsykologiselle klinikalle arvioitaviksi oppimisvaikeuksien vuoksi, sekä kontrolliryhmästä $(\mathrm{n}=119)$. Tutkimuksessa tarkasteltiin ROC (receiver operating characteristic) -analyysin avulla, kuinka hyvin nimeämisnopeuden perusteella pystytään erottamaan eri diagnostiset ryhmät (oppimisvaikeuslapset, joilla oli tai ei ollut lukemisvaikeutta) kontrolliryhmästä ja toisistaan. Lukemisvaikeus määriteltiin erikseen lukemisen nopeuden ja tarkkuuden mukaan. Oppimisvaikeuksien päällekkäisyyden vaikutusta nimeämisvaikeuksien määrään tarkasteltiin vertailemalla ryhmiä, jotka muodostettiin lukemisvaikeuden, matematiikan oppimisvaikeuden, tarkkaavuushäiriön ja näiden päällekkäisyyden perusteella. Tulokset osoittivat, että nimeämisnopeus erotteli parhaiten lukivaikeusryhmiä kontrolliryhmästä riippumatta siitä, oliko lukemisvaikeus määritelty lukemisen tarkkuuden vai nopeuden perusteella. Nimeämisnopeus erotteli luotettavasti myös koko oppimisvaikeusryhmän kontrolliryhmästä sekä lukemisvaikeusryhmän muista oppimisvaikeuksista silloin, kun lukemisvaikeudessa oli kyse lukemisen hitaudesta. Näin ollen tulokset vahvistivat nimeämisnopeuden olevan vahvemmin yhteydessä lukemisen nopeuteen kuin lukemisen tarkkuuteen. Poiketen Waberin ym. tuloksista monen oppimisvaikeuden päällekkäisyys ei näyttänyt tekevän nimeämisvaikeuksia yleisemmiksi. Sen sijaan nimeämisvaikeudet olivat lukemisvaikeusryhmissä yleisempiä kuin niissä oppimisvaikeusryhmissä, joissa lukemisvaikeutta ei ollut. Tutkimuksen johtopäätöksenä voidaan pitää sitä, että kliinisessä aineistossa nimeämisnopeus on vahvemmin yhteydessä lukemisvaikeuksiin kuin muihin oppimisvaikeuksiin, erityisesti kun lukemisvaikeus määritellään lukemisen nopeuden perusteella.

Toisessa osatutkimuksessa tarkasteltiin niin ikään nimeämisnopeuden yhteyttä lukemisen tarkkuuteen ja nopeuteen sekä muihin oppimisen haasteisiin, mutta tarkastelua laajennettiin sisällyttämällä tutkimukseen myös toinen lukemiseen yhteydessä oleva taustamuuttuja, fonologinen tietoisuus. Tavoitteena oli tutkia kaksoisvaikeushypoteesin toteutumista 8-12-vuotiailla lapsilla ( $n=205)$ kliinisessä aineistossa, johon sisältyi lukemisen lisäksi myös muita oppimisen haasteita (matematiikan oppimisvaikeus, tarkkaavuuspulmat). Toisena tavoitteena oli tutkia, liittyvätkö nimeämisen ja fonologisen tietoisuuden vaikeudet erityisesti lukemisvaikeuksiin vai oppimisen haasteisiin yleisemminkin, kuten joissain aikaisemmissa tutkimuksissa on havaittu. Tutkimusryhmä jaettiin neljään kaksoisvaikeushypoteesin mukaiseen ryhmään: kaksoisvaikeus (haasteita sekä nimeämisessä että fonologisessa tietoisuudessa), nimeämisvaikeus, fonologisen tietoisuuden vaikeus sekä ei vaikeutta kummassakaan taustataidossa. Näistä ryhmistä vertailtiin lukemisen nopeutta, lukemisen tarkkuutta, oikeinkirjoitusta, matematiikan osaamista, tarkkaavuutta sekä vielä lukemisvaikeuden, matematiikan oppimisvaikeuden ja tarkkaavuuden ongelmien ylei- 
syyttä. Lisäksi muodostettiin ryhmät yksittäisten ja päällekkäisten lukemisvaikeuksien, matematiikan oppimisvaikeuksien ja tarkkaavuuspulmien perusteella ja vertailtiin nimeämisvaikeuden, fonologisen tietoisuuden vaikeuden ja kaksoisvaikeuden yleisyyttä näissä oppimisvaikeusryhmissä. Tulokset tukivat monilta osin kaksoisvaikeushypoteesia: 1) nimeämisen hitaus ja fonologisen tietoisuuden ongelmat olivat vahvasti yhteydessä lukemisvaikeuksiin, sillä 90 \%:lla niistä lapsista, joilla oli lukemisvaikeus, oli myös jompikumpi tai molemmat näistä taustavaikeuksista, 2) lukemisvaikeus oli yleisempää ja tasoltaan haastavampaa kaksoisvaikeusryhmässä ja 3) nimeämisnopeus ja fonologinen tietoisuus olivat pitkälti toisistaan erillisiä lukemisvaikeuden ennustajia ja näyttivät liittyvän lukemisen eri osa-alueisiin siten, että nimeämisnopeus oli erityisesti yhteydessä lukemisen nopeuteen ja sujuvuuteen, kun taas fonologinen tietoisuus oli vahvemmin yhteydessä lukemisen tarkkuuteen ja toisaalta oikeinkirjoitukseen. Ryhmät, joissa oli yksittäisiä nimeämisnopeuden tai fonologisen tietoisuuden vaikeuksia, eivät kuitenkaan eronneet toisistaan tai kontrolliryhmästä lukemisen mittareissa, ainoastaan oikeinkirjoittamisessa. Toinen tutkimuksen päätulos liittyy nimeämisnopeuden ja fonologisen tietoisuuden rooliin spesifeinä lukemisen taustataitoina. Tulosten mukaan vaikeudet nimeämisessä ja fonologisessa tietoisuudessa liittyvät erityisesti lukemisvaikeuksiin, eivät niinkään laajemmin oppimisen haasteisiin, sillä 1) kaksoisvaikeushypoteesin mukaiset ryhmät erosivat toisistaan lukemisen ja kirjoittamisen taidoissa mutta eivät matematiikassa tai tarkkaavuudessa, 2) kaksoisvaikeus oli yleisempi ryhmissä, joissa esiintyi lukemisvaikeutta, kuin muissa oppimisvaikeusryhmissä ja 3) nimeämisnopeus ja fonologinen tietoisuus korreloivat lukemisen ja oikeinkirjoittamisen kanssa mutta eivät matematiikan tai tarkkaavuuden kanssa. Tutkimuksen johtopäätöksenä oli ensinnäkin se, että kaksoisvaikeushypoteesi sai tukea myös kliinisestä aineistosta, johon kuuluvilla lapsilla oli päällekkäisiä oppimisen haasteita, sekä se, että vaikeudet nimeämisessä ja fonologisessa tietoisuudessa ovat yhteydessä erityisesti lukemisen ja oikeinkirjoittamisen taitoihin, eivät niinkään muihin oppimisen haasteisiin.

Kolmannessa osatutkimuksessa tarkasteltiin kolmen lukemisen sujuvuuteen tähtäävän intervention vaikuttavuutta harjoiteltujen ärsykkeiden (tavujen) lukemissujuvuuteen sekä harjoittelun tulosten siirtovaikutusta sana- ja tekstitasolle. Tutkimuksen tavoitteena oli myös selvittää, vaikuttavatko nimeämisnopeus ja lukemisen sujuvuuden lähtötaso intervention tuloksellisuuteen, kuten joissakin aikaisemmissa tutkimuksissa on havaittu. Tutkimukseen osallistui tois- ja kolmasluokkalaisia heikkoja lukijoita $(n=150)$, jotka saivat erityisopetusta lukemisvaikeuksien vuoksi. Tutkimusryhmä jaettiin kontrolliryhmään ja kolmeen harjoitteluryhmään, jotka harjoittelivat yleisyydeltään ja pituudeltaan erilaisia tavuja. Interventio tapahtui opettajan tai erityisopettajan ohjauksessa, ja se koostui kymmenestä harjoittelukerrasta, joissa kutakin harjoiteltavaa tavua toistettiin yhteensä 50 kertaa. Lapsi valitsi kuulemansa tavun tietokoneen ruudulta viiden vaihtoehdon joukosta mahdollisimman nopeasti ja sai palautteen oikean vastauksen nopeuden perusteella. Harjoiteltujen tavujen ja kontrollitavujen lukemisen nopeutta arvioitiin ennen ja jälkeen harjoittelujakson. Siirto- 
vaikutusta sana- ja tekstitasolle arvioitiin mittaamalla, kuinka sujuvasti lapsi luki harjoiteltuja tavuja sisältäviä epäsanoja sekä tekstiä, joka ei juuri sisältänyt harjoiteltuja tavuja. Nimeämisnopeutta arvioitiin ennen intervention alkamista. Tulokset osoittivat, että harjoiteltujen tavujen lukeminen nopeutui kaikissa harjoitteluryhmissä kontrolliryhmään verrattuna. Muutos oli suurin pitkissä harvinaisissa tavuissa, joissa $75 \%$ harjoitteluryhmäläisistä edistyi merkitsevästi kontrolliryhmään nähden. Lyhyissä tavuissa harjoittelun vaikutus näkyi sillä neljänneksellä lapsista, joiden lukemisen alkutaso oli harjoittelun alussa heikoin. Odotuksen mukaisesti harjoittelulla ei ollut siirtovaikutusta sellaisen tekstin lukemiseen, joka ei sisältänyt harjoiteltuja tavuja. Sen sijaan sanatasolla havaittiin, että harjoittelu helpottaa myös sellaisten epäsanojen lukemista, jotka sisälsivät harjoiteltuja tavuja. Lyhyen harjoittelujakson aikana (yhteensä 1-2 tuntia harjoittelua) siirtovaikutus sanatasolle ei kuitenkaan noussut merkitseväksi millään muulla ryhmällä kuin sillä, jolla harjoitteluvaikutus tavuissa oli suurin. Nimeämisen nopeus oli yhteydessä lukemisnopeuden alkutasoon mutta ei näyttänyt vaikuttavan harjoittelun tuloksellisuuteen. Lukemisen alkutaso ennusti harjoitteluefektiä lyhyissä mutta ei pitkissä tavuissa siten, että lukemisen alkutasoltaan heikoimmat edistyivät harjoittelun aikana eniten.

Tämän tutkimuksen tulokset osoittivat, että suomen kielessä, jossa on selkeä tavurakenne ja säännönmukainen kirjoitusjärjestelmä, tietokoneistettu tavuharjoittelu on lupaava keino tukea lukemissujuvuutta heti peruslukutaidon omaksumisen jälkeen. Harjoittelun yleistymistä ajatellen tässä tutkimuksessa kuvattua pitempi harjoittelujakso on kuitenkin tarpeen. Samoin yleistymistä on syytä eksplisiittisesti tukea. Tulos, jonka mukaan lukemisen tai nimeämisen hitaus ei heikennä harjoittelun tuloksellisuutta, oli käytännön kannalta rohkaiseva. Tulokset tukevat varhaisen puuttumisen merkitystä lukemisen sujuvuuden tukemisessa. Tämän tutkimuksen tulokset tukevat ja vahvistavat nimeämisnopeuden asemaa lukemisen sujuvuuden ennustajana ja lukemisvaikeuksien itsenäisenä taustatekijänä kirjoitusjärjestelmältään säännönmukaisessa suomen kielessä, jossa lukemisvaikeudet ovat ensisijaisesti lukemisen sujuvuuden ongelmia. Vaikka lukemisvaikeudet esiintyvät usein yhdessä matematiikan oppimisvaikeuksien ja tarkkaavuuden haasteiden kanssa, tässä tutkimuksessa nimeämisnopeus näytti liittyvän ensisijaisesti lukemiseen eikä niinkään oppimisen haasteisiin yleisemmällä tasolla. Kliinisessä työssä oppimisvaikeuksien päällekkäisyys on kuitenkin tärkeää ottaa huomioon sekä arvioinnissa että kuntoutuksen suunnittelussa, sillä erilaiset haasteiden ja vahvuuksien yhdistelmät saattavat reagoida kuntoutukseen eri tavoin. Vaikka nopean nimeämisen ja lukemisen sujuvuuden ongelmien tiedetään olevan sitkeitä, tämän tutkimuksen valossa lukemisen sujuvuuden haasteet eivät kuitenkaan näytä voittamattomilta edes silloin, kun vaikeuksien taustalla on nimeämisen hitaus. 


\section{REFERENCES}

Aarnoutse, C., van Leeuwe, J., \& Verhoeven, L. (2005). Early literacy from a longitudinal perspective. Educational Review and Research, 11, 253-275.

Ackerman, P. T. \& Dykman, R. A. (1993). Phonological processes, confrontational naming, and immediate memory in dyslexia. Journal of Learning Disabilities, 26, 597-609.

Ackerman, P. T., Holloway, C. A., Youngdahl, P. L., \& Dykman, R. A. (2001). The double-deficit theory of reading disability does not fit all. Learning Disabilities Research \& Practice, 16, 152-160.

Adlof, S. M., Perfetti, C. A., \& Catts, H. W. (2011). Developmental changes in reading comprehension: Implications for assessment and instruction. In S. M. Samuels \& A. E. Farstrup (Eds.), What research has to say about reading instruction (pp. 186-214). Newark, DE: International Reading Association.

Albuquerque, C. P. \& Simões, M. R. (2010). Rapid naming tests: Developmental course and relations with neuropsychological measures. The Spanish Journal of Psychology, 13, 88-100.

Allor, J. H. (2002). The relationships of phonemic awareness and rapid naming to reading development. Learning Disability Quarterly, 25, 47-57.

Al Otaiba, S. \& Fuchs, D. (2002). Characteristics of children who are unresponsive to early literacy intervention: A review of the literature. Remedial and Special Education, 23, 300-316.

Al Otaiba, S. \& Fuchs, D. (2006). Who are the young children for whom best practices in reading are ineffective? An experimental and longitudinal study. Journal of Learning Disabilities, 39, 414-431.

Altemeier, L. E., Abbott, R. D., \& Berninger, V. W. (2008). Executive functions for reading and writing in typical literacy development and dyslexia. Journal of Clinical and Experimental Neuropsychology, 30, 588-606.

Anderson, S. W., Podwall, F. N. \& Jaffe, J. (1984). Timing and analysis of coding and articulation processes in dyslexia. Annals of the New York Academy of Sciences, 433, 71-86.

Ans, B., Carbonnel, S., \& Valdois, S. (1998). A connectionist multiple-trace memory model for polysyllabic word reading. Psychological Review, 105, 678-723.

Araújo, S., Inácio, F., Francisco, A., Faísca, L., Petersson, K. M. and Reis, A. (2011). Component processes subserving rapid automatized naming in dyslexic and non-dyslexic readers. Dyslexia, 17, 242-255.

Araújo, S., Reis, A., Petersson, K. M., \& Faísca, L. (2014). Rapid automatized naming and reading performance: A meta-analysis. Journal of Educational Psychology. Advance online publication. doi:10.1037/edu0000006

Arnell, K. M., Joanisse, M. F., Klein, R. M., Busseri, M. A., \& Tannock, R. (2009). Decomposing the relation between rapid automatized naming (RAN) and reading ability. Canadian Journal of Experimental Psychology, 63, 173-184.

Arnett, A. B., Pennington, B. F., Willcutt, E., Dmitrieva, J., Byrne, B., Samuelsson, S., \& Olson, R. K. (2012). A cross-lagged model of the development of 
ADHD inattention symptoms and rapid naming speed. Journal of Abnormal Child Psychology, 40, 1313-1326.

Aro, M. (2006). Learning to read: The effect of orthography. In R. M. Joshi \& P. G. Aaron (Eds.), Handbook of orthography and literacy (pp. 531-550). Mahwah, NJ: Erlbaum.

Aro, M. \& Wimmer, H. (2003). Learning to read: English in comparison to six more regular onhographies. Applied Psycholinguistics, 26, 619-634.

Aro, T., Ahonen, T., Tolvanen, A., Lyytinen, H., \& de Barra, H. T. (1999). Contribution of ADHD characteristics to the academic treatment outcome of children with learning difficulties. Developmental Neuropsychology, 15, 291-305.

Badian, N. A. (1993). Phonemic awareness, naming, visual symbol processing, and reading. Reading and Writing: An Interdisciplinary Journal, 5, 87-100.

Bental, B. \& Tirosh, E. (2007). The relationship between attention, executive functions and reading domain abilities in attention deficit hyperactivity disorder and reading disorder: A comparative study. Journal of Child Psychology and Psychiatry, 48, 455-463.

Berends, I. E. \& Reitsma, P. (2006). Remediation of fluency: Word specific or generalised training effects? Reading and Writing: An Interdisciplinary Journal, 19, 221-234.

Berg, S., Poutanen, M., Kangas, T., Peltomaa, K., Korkman, M., Lahti-Nuuttila, P., \& Hokkanen, L. (2014). Eri nimeämistaitojen yhteys myöhempiin lukitaitoihin [The association between various naming skills and later literacy skills]. Psykologia, 49, 41-63.

Berninger, V. W., Abbott, R. D., Trivedi, P., Olson, E., Gould, L., Hiramatsu, S., Holsinger, M., McShane, M., Murphy, H., Norton, J., Boyd, A. S., \& Westhaggen, S. Y. (2010). Applying the multiple dimensions of reading fluency to assessment and instruction. Journal of Psychoeducational Assessment, 28, 3-18.

Berninger, V. W., Abbott, R. D., Vermeulen, K., Ogier, S., Brooksher, R., Zook, D., \& Lemos, Z. (2002). Comparison of faster \& slower responders to early intervention in reading: Differentiating features of their language profiles. Learning Disability Quarterly, 25, 59-76.

Berninger, V. W., Abbott, R. D., Zook, D., Ogier, S., Lemos-Britton, Z., \& Brooksher, R. (1999). Early intervention for reading disabilities teaching the alphabet principle in a connectionist framework. Journal of Learning Disabilities, 32, 491-503.

Boada, R., Willcutt, E. G., Pennington, B. F. (2012). Understanding the comorbidity between dyslexia and Attention-Deficit/Hyperactivity Disorder. Topics in Language Disorders, 32, 264-284.

Bowers, P. G. (1993). Text reading and rereading: Determinants of fluency beyond word recognition. Journal of Reading Behavior, 25, 133-153.

Bowers, P. G. (1995). Tracing symbol naming speed's unique contributions to reading disability over time. Reading and Writing: An Interdisciplinary Journal, 7, 189-216. 
Bowers, P. G. (2001). Exploration of the basis for rapid naming's relationship to reading. In M. Wolf (Ed.), Dyslexia, fluency, and the brain (pp. 41-63). Timonium, MD: York Press.

Bowers, P. G., Golden, J., Kennedy, A., \& Young, A. (1994). Limits upon orthographic knowledge due to processes indexed by naming speed. In V. $\mathrm{W}$. Berninger (Ed.), The varieties of orthographic knowledge I: Theoretical and developmental issues (pp. 173-218). Dordrecht: Kluwer Academic.

Bowers, P. G. \& Ishaik, G. (2003). RAN's contribution to understanding reading disabilities. In H. L. Swanson, K. R. Harris, \& S. Graham (Eds.), Handbook of learning disabilities (pp. 140-157). New York: Guilford.

Bowers, P. G. \& Newby-Clark, E. (2002). The role of naming speed within a model of reading acquisition. Reading and Writing: An Interdisciplinary Journal, 15, 109-126.

Bowers, P. G., Steffy, R., \& Tate, E. (1988). Comparison of the effects of IQ control methods on memory and naming speed predictors of reading disability. Reading Research Quarterly, 23, 304-319.

Bowers, P. G., Sunseth, K., \& Golden, J. (1999). The route between rapid naming and reading progress. Scientific Studies of Reading, 3, 31-53.

Bowers, P. G. \& Swanson, L.B. (1991). Naming speed deficits in reading disability. Journal of Experimental Child Psychology, 51, 195-219.

Bowers, P.G. \& Wolf, M. (1993). Theoretical links among naming speed, precise timing mechanisms and orthographic skill in dyslexia. Reading and Writing: An Interdisciplinary Journal, 5, 69-85.

Bowey, J. A., McGuigan, M., \& Ruschena, A. (2005). On the association between serial naming speed for letters and digits and wordreading skill: Towards a developmental account. Journal of Research in Reading, 28, 400-422.

Bowey, J. A. \& Miller, R. (2007). Correlates of orthographic learning in thirdgrade children's silent reading. Journal of Research in Reading, 30, 115-128.

Braisby, N. \& Dockrell, J. (1999). Why is colour naming difficult?. Journal of Child Language, 26, 23-47.

Branum-Martin, L., Fletcher, J. M., \& Stuebing, K. K. (2013). Classification and identification of reading and math disabilities: The special case of comorbidity. Journal of Learning Disabilities, 46, 490-499.

Breznitz, Z. (2006). Fluency in reading: Synchronization of processes. Mahwah, NJ: Erlbaum.

Burani, C., Marcolini, S., De Luca, M., \& Zoccolotti, P. (2008). Morpheme-based reading aloud: Evidence from dyslexic and skilled Italian readers. Cognition, 108, 243-262.

Byrne, B., Olson, R. K., Samuelsson, S., Wadsworth, S., Corley, R., DeFries, J. C., \& Willcutt, E. (2006). Genetic and environmental influences on early literacy. Journal of Research in Reading, 29, 33-49.

Byrne, B., Wadsworth, S., Corley, R., Samuelsson, S., Quain, P., DeFries, J. C., Willcutt, E., \& Olson, R. K. (2005). Longitudinal twin study of early literacy development: Preschool and kindergarten phases. Scientific Studies of Reading, 9, 219-235. 
Caravolas, M., Lervåg, A., Defior, S., Málková, G. S., \& Hulme, C. (2013). Different patterns, but equivalent predictors, of growth in reading in consistent and inconsistent orthographies. Psychological Science, 24, 13981407.

Caravolas, M., Lervåg, A., Mousikou, P., Efrim, C., Litavský, M., OnochieQuintanilla, E., Hulme, C. (2012). Common patterns of prediction of literacy development in different alphabetic orthographies. Psychological Science, 23, 678-686.

Cardoso-Martins, C., \& Pennington, B. F. (2004). The relationship between phoneme awareness and rapid serial naming skills and literacy acquisition: The role of developmental period and reading ability. Scientific Studies of Reading, 8, 27-52.

Carte, E. T., Nigg, J. T., \& Hinshaw, S. P. (1996). Neuropsychological functioning, motor speed, and language processing in boys with and without ADHD. Journal of Abnormal Child Psychology, 24, 481-498.

Carver, R. P. (1991). Using letter-naming speed to diagnose reading disability. Remedial and Special Education, 12(5), 33-43.

Catts, H. W., Gillispie, M., Leonard, L. B., Kail, R. V., \& Miller, C. A. (2002). The role of speed of processing, rapid naming, and phonological awareness in reading achievement. Journal of Learning Disabilities, 35, 510-525.

Chard, D. J., Vaughn, S., \& Tyler, B.-J. (2002). A synthesis of research on effective interventions for building reading fluency with elementary students with learning disabilities. Journal of Learning Disabilities, 35, 386406.

Chiappe, P., Stringer, R., Siegel, L. S., \& Stanovich, K. E. (2002). Why the timing deficit hypothesis does not explain reading disability in adults. Reading and Writing: An Interdisciplinary Journal, 15, 73-107.

Christopher, M. E., Hulslander, J., Byrne, B., Samuelsson, S., Keenan, J. M., Pennington, B., DeFries, J. C., Wadsworth, S. J., Willcutt, E., \& Olson, R. K. (2015). Genetic and environmental etiologies of the longitudinal relations between prereading skills and reading. Child Development, 86, 342-361.

Christopher, M. E., Miyake, A., Keenan, J. M., Pennington, B., DeFries, J. C., Wadsworth, S. J., Willcutt, E., \& Olson, R. K. (2012). Predicting word reading and comprehension with executive function and speed measures across development: A latent variable analysis. Journal of Experimental Psychology: General, 141, 470-488.

Clarke, P., Hulme, C., \& Snowling, M. J. (2005). Individual differences in RAN and reading: A response timing analysis. Journal of Research in Reading, 28, 73-86.

Compton, D. L. (2000). Modeling the growth of decoding skills in first-grade children. Scientific Studies of Reading, 4, 219-259.

Compton, D. L., DeFries, J. C., \& Olson, R. K. (2001). Are RAN and phonological deficits additive in children with reading disabilities? Dyslexia, 7, 125-149. 
Compton, D. L., Fuchs, L. S., Fuchs, D., Lambert, W., \& Hamlett, C. (2012). The cognitive and academic profiles of reading and mathematics learning disabilities. Journal of Learning Disabilities, 45, 79-95.

Conrad, N. J. \& Levy, B. A. (2007). Letter processing and the formation of memory representations in children with naming speed deficits. Reading and Writing: An Interdisciplinary Journal, 20, 201-223.

Conrad, N. J. \& Levy, B. A. (2011). Training letter and orthographic pattern recognition in children with slow naming speed. Reading and Writing: An Interdisciplinary Journal, 24, 91-115.

Cornwall, A. (1992). The relationship of phonological awareness, rapid naming, and verbal memory to severe reading and spelling disability. Journal of Learning Disabilities, 25, 532-538.

Cronin, V. (2013). RAN and double-deficit theory. Journal of Learning Disabilities, $46,182-190$.

Cronin, V. \& Carver, P. (1998). Phonological sensitivity, rapid naming, and beginning reading. Applied Psycholinguistics, 19, 447-461.

Cummine, J., Szepesvari, E., Chouinard, B., Hanif, W., \& Georgiou, G. K. (2014). A functional investigation of RAN letters, digits, and objects: How similar are they? Behavioural Brain Research, 275, 157-165.

Cutting, L. E. \& Denckla, M. B. (2001). The relationship of rapid serial naming and word reading in normally developing readers: An exploratory model. Reading and Writing: An Interdisciplinary Journal, 14, 673-705.

Czamara, D., Tiesler, C. M., Kohlböck, G., Berdel, D., Hoffmann, B., Bauer, C. P., Koletzko, S., Schaaf, B., Lehmann, I., Herbarth, O., von Berg, A., MüllerMyhsok, B., Schulte-Körne, G., \& Heinrich, J. (2013). Children with ADHD symptoms have a higher risk for reading, spelling and math difficulties in the GINIplus and LISAplus cohort studies. PloS ONE, 8, e63859. doi:10.1371/journal.pone.0063859

Davis, C. J., Gayán, J., Knopik, V. S., Smith, S. D., Cardon, L. R., Pennington, B. F., Olson, R. K., \& DeFries, J. C. (2001). Etiology of reading difficulties and rapid naming: The Colorado Twin Study of Reading Disability. Behavior Genetics, 31, 625-635.

Davis, J. M., \& Spring, C. (1990). The digit naming speed test: Its power and incremental validity in identifying children with specific reading disabilities. Psychology in the Schools, 27, 15-22.

de Jong, P. F. (2011). What discrete and serial rapid automatized naming can reveal about reading. Scientific Studies of Reading, 15, 314-337.

de Jong, P. F. \& van der Leij, A. (1999). Specific contributions of phonological abilities to early reading acquisition: Results from a Dutch latent variable longitudinal study. Journal of Educational Psychology, 91, 450-476.

de Jong, P. F. \& van der Leij, A. (2002). Effects of phonological abilities and linguistic comprehension on the development of reading. Scientific Studies of Reading, 6, 51-77. 
de Jong, P. F. \& van der Leij, A. (2003). Developmental changes in the manifestation of a phonological deficit in dyslexic children learning to read a regular orthography. Journal of Educational Psychology, 95, 22-40.

de Jong, P. F. \& Vrielink, L. O. (2004). Rapid automatic naming: Easy to measure, hard to improve (quickly). Annals of Dyslexia, 54, 65-88.

DeMann, J. \& Thornton, J. (2014). B-30 Component processes in reading fluency: Letter naming and general processing speed. Archives of Clinical Neuropsychology, 29, 547 .

Denckla, M. B. \& Cutting, L. E. (1999). History and significance of rapid automatized naming. Annals of Dyslexia, 49, 29-42.

Denckla, M. B. \& Rudel, R. (1976). Rapid "automatized" naming (RAN): Dyslexia differentiated from other learning disabilities. Neuropsychologia, 14, 471-479.

Denckla, M. B., Rudel, R. G., \& Broman, M. (1981). Tests that discriminate between dyslexic and other learning-disabled boys. Brain and Language, 13, 118-129.

Di Filippo, G., Brizzolara, D., Chilosi, A., De Luca, M., Judica, A., Pecini, C., Spinelli, D., \& Zoccolotti, P. (2006). Naming speed and visual search deficits in readers with disabilities: Evidence from an orthographically regular language (Italian). Developmental Neuropsychology, 30, 885-904.

DuPaul, G. J., Gormley, M. J., \& Laracy, S. D. (2013). Comorbidity of LD and ADHD: Implications of DSM-5 for assessment and treatment. Journal of Learning Disabilities, 46, 43-51.

Durand, M., Hulme, C., Larkin, R., \& Snowling, M. (2005). The cognitive foundations of reading and arithmetic skills in 7-to 10-year-olds. Journal of Experimental Child Psychology, 91, 113-136.

Eklund, K., Torppa, M., Aro, M., Leppänen, P. H. T., \& Lyytinen, H. (2015). Literacy skill development of children with familial risk for dyslexia through grades 2, 3, and 8. Journal of Educational Psychology, 107, 126-140.

Eklund, K. M., Torppa, M., \& Lyytinen, H. (2013). Predicting reading disability: Early cognitive risk and protective factors. Dyslexia, 19, 1-10.

Elliott, J. G. \& Grigorenko, E. L. (2014). The dyslexia debate (Vol. 14). New York: Cambridge University Press.

Escribano, C.L. (2007). Evaluation of the double-deficit hypothesis subtype classification of readers in Spanish. Journal of Learning Disabilities, 40, 319330.

Fawcett, A. J. \& Nicholson, R. I. (2001). Speed and temporal processing in dyslexia. In M. Wolf (Ed.), Dyslexia, fluency and the brain (pp. 23-40). Timonium, MD: York Press.

Felton, R. H. \& Wood, F. B. (1989). Cognitive deficits in reading disability and attention deficit disorder. Journal of Learning Disabilities, 22, 3-13.

Felton, R. H., Wood, F. B., Brown, I. S., Campbell, S. K., \& Harter, M. R. (1987). Separate verbal memory and naming deficits in attention deficit disorder and reading disability. Brain and Language, 31, 171-184. 
Fletcher, J. M. (2005). Predicting math outcomes: Reading predictors and comorbidity. Journal of Learning Disabilities, 38, 308-312.

Fletcher, J. M., Stuebing, K. K., Barth, A. E., Denton, C. A., Cirino, P. T., Francis, D. J., \& Vaughn, S. (2011). Cognitive correlates of inadequate response to intervention. School Psychology Review, 40, 2-22.

Flynn, L. J., Zheng, X., \& Swanson, H. L. (2012). Instructing struggling older readers: A selective meta-analysis of intervention research. Learning Disabilities Research \& Practice, 27, 21-32.

Francis, D. J., Shaywitz, S. E., Stuebing, K. K., Shaywitz, B. A., \& Fletcher, J. M. (1996). Developmental lag versus deficit models of reading disability: A longitudinal, individual growth curves analysis. Journal of Educational Psychology, 88, 3-17.

Frost, R., Katz, L., \& Bentin, S. (1987). Strategies for visual word recognition and orthographical depth: A multilingual comparison. Journal of Experimental Psychology: Human Perception and Performance, 13, 104-115.

Fuchs, L. S., Fuchs, D., \& Compton, D. L. (2013). Intervention effects for students with comorbid forms of learning disability: Understanding the needs of nonresponders. Journal of Learning Disabilities, 46, 534-548.

Fuchs, L. S., Fuchs, D., Hosp, M. K., \& Jenkins, J. (2001). Oral reading fluency as an indicator of reading competence: A theoretical, empirical, and historical analysis. Scientific Studies of Reading, 5, 239-256.

Fugate, M.H. (1997). Letter training and its effect on the development of beginning reading skills. School Psychology Quarterly, 12, 170-192.

Furnes, B. \& Samuelsson, S. (2011). Phonological awareness and rapid automatized naming predicting early development in reading and spelling: Results from a cross-linguistic longitudinal study. Learning and Individual Differences, 21, 85-95.

Galuschka, K., Ise, E., Krick, K., \& Schulte-Körne, G. (2014). Effectiveness of treatment approaches for children and adolescents with reading disabilities: A meta-analysis of randomized controlled trials. PloS one, 9, e89900. doi:10.1371/journal.pone.0089900

Gasperini, F., Brizzolara, D., Cristofani, P., Casalini, C., \& Chilosi, A. M. (2014). The contribution of discrete-trial naming and visual recognition to rapid automatized naming deficits of dyslexic children with and without a history of language delay. Frontiers in Human Neuroscience, 8, 652. doi:10.3389/fnhum.2014.00652

Geary, D. C. (1993). Mathematical disabilities: Cognitive, neuropsychological, and genetic components. Psychological Bulletin, 114, 345-362.

Geary, D. C., Hamson, C., \& Hoard, O. (2000). Numerical and arithmetical cognition: A longitudinal study of process and concept deficits in children with learning disability. Journal of Experimental Child Psychology, 77, 236263.

Gellert, A. S. (2014). Does repeated reading predict reading development over time? A study of children from grade 3 to 4 . Scandinavian Journal of Psychology, 55, 303-310. 
Georgiou, G. K., Aro, M., Liao, C. H., \& Parrila, R. (2015). The contribution of RAN pause time and articulation time to reading across languages: Evidence from a more representative sample of children. Scientific Studies of Reading, 19, 135-144.

Georgiou, G. K., Papadopoulos, T. C., Fella, A., \& Parrila, R. (2012). Rapid naming speed components and reading development in a consistent orthography. Journal of Experimental Child Psychology, 112, 1-17.

Georgiou, G. K., Papadopoulos, T. C., \& Kaizer, E. L. (2014). Different RAN components relate to reading at different points in time. Reading and Writing, 8, 1379-1394.

Georgiou, G. \& Parrila, R. (2013). Rapid naming and reading: A review. In H. L. Swanson, K. L. Harris, \& S. Graham (Eds.), Handbook of learning disabilities (pp. 169-185). New York: Guilford.

Georgiou, G. K., Parrila, R., Cui, Y., \& Papadopoulos, T. C. (2013). Why is rapid automatized naming related to reading?. Journal of Experimental Child Psychology, 115, 218-225.

Georgiou, G. K., Parrila, R., \& Kirby, J. R. (2006). Rapid naming speed components and early reading acquisition. Scientific Studies of Reading, 10, 199-220.

Georgiou, G. K., Parrila, R., \& Kirby, J. R. (2009). RAN components and reading development from grade 3 to grade 5: What underlies their relationship? Scientific Studies of Reading, 13, 508-534.

Georgiou, G. K., Parrila, R., Kirby, J. R., \& Stephenson, K. (2008). Rapid naming components and their relationship with phonological awareness, orthographic knowledge, speed of processing, and different reading outcomes. Scientific Studies of Reading, 12, 325-350.

Georgiou, G. K., Parrila, R., \& Liao, C.-H. (2008). Rapid naming speed and reading across languages that vary in orthographic consistency. Reading and Writing, 21, 885-903.

Georgiou, G. K., Parrila, R., Manolitsis, G., \& Kirby, J. R. (2011). Examining the importance of assessing rapid automatized naming (RAN) for the identification of children with reading difficulties. Learning Disabilities: A Contemporary Journal, 9(2), 5-26.

Georgiou, G. K., Parrila, R., \& Papadopoulos, T.C. (2008). Predictors of word decoding and reading fluency in English and Greek: A cross-linguistic comparison. Journal of Educational Psychology, 100, 566-580.

Georgiou, G. K., Torppa, M., Manolitsis, G., Lyytinen, H., \& Parrila, R. (2012). Longitudinal predictors of reading and spelling across languages varying in orthographic consistency. Reading and Writing, 25, 321-346.

Georgiou, G. K., Tziraki, N., Manolitsis, G., \& Fella, A. (2013). Is rapid automatized naming related to reading and mathematics for the same reason(s)? A follow-up study from kindergarten to grade 1. Journal of Experimental Child Psychology, 115, 481-496.

Germanò, E., Gagliano, A. M.D. \& Curatolo, P. (2010). Comorbidity of ADHD and dyslexia. Developmental Neuropsychology, 35, 475-493. 
Germano, G. D., Reilhac, C., Capellini, S. A., \& Valdois, S. (2014). The phonological and visual basis of developmental dyslexia in Brazilian Portuguese reading children. Frontiers in Psychology, 5, 1169. doi:10.3389/fpsyg.2014.01169

Gooch, D., Snowling, M., \& Hulme, C. (2011). Time perception, phonological skills and executive function in children with dyslexia and/or ADHD symptoms. Journal of Child Psychology and Psychiatry 52, 195-203.

Hammill, D. D. (2004). What we know about correlates of reading. Exceptional Children, 70, 453-468.

Hammill, D. D., Mather, N., Allen, E. A. \& Roberts, R. (2002). Using semantics, grammar, phonology, and rapid naming tasks to predict word identification. Journal of Learning Disabilities, 35, 121-136.

Hart, S. A., Petrill, S. A., Willcutt, E., Thompson, L. A., Schatschneider, C., Deater-Deckard, K., \& Cutting, L. E. (2010). Exploring how symptoms of attention-deficit/hyperactivity disorder are related to reading and mathematics performance general genes, general environments. Psychological Science, 21, 1708-1715.

Hecht, S. A., Torgesen, J. K., Wagner, R. K., \& Rashotte, C. A. (2001). The relations between phonological processing abilities and emerging individual differences in mathematical computation skills: A longitudinal study from second to fifth grades. Journal of Experimental Child Psychology, $79,192-227$.

Heinola, K., Latvala, J.-M., Heikkilä, R. \& Lyytinen, H. (2010). Lukutaidon ennustaminen esikouluiässä - Lapsen tuen tarpeen tunnistaminen lukemaan oppimisessa ensimmäisellä ja toisella luokalla. [Predicting reading skills on kindergarten age - Recognizing the need for support in learning to read on first and second grade]. NMI-Bulletin, 20 (4), 35-49.

Hintikka, S., Landerl, K., Aro, M., \& Lyytinen, H. (2008). Training reading fluency: Is it important to practice reading aloud and is generalization possible? Annals of Dyslexia 58, 59-79.

Holland, J., McIntosh, D., \& Huffman, L. (2004). The role of phonological awareness, rapid automatized naming, and orthographic processing in word reading. Journal of Psychoeducational Assessment, 22, 233-260.

Holopainen, L., Ahonen, T., \& Lyytinen, H. (2001). Predicting delay in reading achievement in a highly transparent language. Journal of Learning Disabilities, 34, 401-413.

Huemer, S. (2009). Training reading skills: Towards fluency. Jyväskylä Studies in Education, Psychology and Social Research, 360.

Huemer, S., Aro, M., Landerl, K., \& Lyytinen, H. (2010). Repeated reading of syllables among Finnish-speaking children with poor reading skills. Scientific Studies of Reading, 14, 317-340.

Hynd, G. W., Lorys, A. R., Semrud-Clikeman, M., Nieves, N., Huettner, M. I. S., \& Lahey, B. B. (1991). Attention deficit disorder without hyperactivity: A distinct behavioral and neurocognitive syndrome. Journal of Child Neurology, 6, 37-43. 
Jacobson, L. A., Ryan, M., Martin, R. B., Ewen, J., Mostofsky, S. H., Denckla, M. B., \& Mahone, E. M. (2011). Working memory influences processing speed and reading fluency in ADHD. Child Neuropsychology, 17, 209-224.

Jiménez, J. E., Hernández-Valle, I., Rodríguez, C., Guzmán, R., Díaz, A., \& Ortiz, R. (2008). The double-deficit hypothesis in Spanish developmental dyslexia. Topics in Language Disorders, 28, 46-60.

Johnson, C. J., Paivio, A., \& Clark, J. M. (1996). Cognitive components of picture naming. Psychological Bulletin, 120, 113-139.

Jones, M. W., Branigan, H. P., Hatzidaki, A., \& Obregón, M. (2010). Is the 'naming' deficit in dyslexia a misnomer? Cognition, 116, 56-70.

Juul, H., Poulsen, M., \& Elbro, C. (2014). Separating speed from accuracy in beginning reading development. Journal of Educational Psychology, 106, 1096-1106.

Kail, R. \& Hall, L.K. (1994). Speed of processing, naming speed, and reading. Developmental Psychology, 30, 949-954.

Kail, R., Hall, L.K., \& Caskey, B.J. (1999). Processing speed, exposure to print, and naming speed. Applied Psycholinguistics, 20, 303-314.

Kairaluoma, L., Torppa, M., Westerholm, J., Ahonen, T., Aro, M. (2013). The nature of and factors related to reading difficulties among adolescents in a transparent orthography. Scientific Studies of Reading, 17, 315-332.

Kame'enui, E. J. \& Simmons, D. C. (2001). Introduction to this special issue: The DNA of reading fluency. Scientific Studies of Reading, 5, 203-210.

Karlsson, F. (2008). Finnish: An essential grammar (2nd ed.). London: Routledge.

Katzir, T., Kim, Y., Wolf, M., O’Brien, B., Kennedy, B., Lovett, M., \& Morris, R. (2006). Reading fluency: The whole is more than the parts. Annals of Dyslexia, 56, 51-82.

Kibby, M. Y., Lee, S. E., \& Dyer, S. M. (2014). Reading performance is predicted by more than phonological processing. Frontiers in Psychology, 5, 960. doi:10.3389/fpsyg.2014.00960

Kim, Y. S., Petscher, Y., Schatschneider, C., \& Foorman, B. (2010). Does growth rate in oral reading fluency matter in predicting reading comprehension achievement? Journal of Educational Psychology, 102, 652.

Kirby, J. R., Georgiou, G. K., Martinussen, R., \& Parrila, R. (2010). Naming speed and reading: From prediction to instruction. Reading Research Quarterly, 45, 341-362.

Kirby, J. R., Parrila, R., \& Pfeiffer, S. (2003). Naming speed and phonological awareness as predictors of reading development. Journal of Educational Psychology, 95, 453-464.

Klauda, S. L. \& Guthrie, J.T. (2008). Relationships of three components of reading fluency to reading comprehension. Journal of Educational Psychology, 100, 310-321.

Klein, R. M. (2002). Observations on temporal correlates of reading failure. Reading and Writing: An Interdisciplinary Journal, 15, 207-232.

Koponen, T., Aunola, K., Ahonen, T., \& Nurmi, J.-E. (2007). Cognitive predictors of single-digit and procedural calculation skills and their 
covariation with reading skill. Journal of Experimental Child Psychology, 97, 220-241.

Koponen, T., Salmi, P., Eklund, K., \& Aro, T. (2013). Counting and RAN: Predictors of arithmetic calculation and reading fluency. Journal of Educational Psychology, 105, 162-175.

Korhonen, T. T. (1995). The persistence of rapid naming problems in children with reading disabilities: A nine-year follow-up. Journal of Learning Disabilities, 28, 232-239.

Kovas, Y., Haworth, C. M. A., Harlaar, N., Petrill, S. A., Dale, P. S., \& Plomin, R. (2007). Overlap and specificity of genetic and environmental influences on mathematics and reading disability in 10-year-old twins. Journal of Child Psychology and Psychiatry, 48, 914-922.

Krajewski, K. \& Schneider, W. (2009). Early development of quantity to number-word linkage as a precursor of mathematical school achievement and mathematical difficulties: Findings from a four-year longitudinal study. Learning and Instruction, 19, 513-526.

Kuhn, M. R. \& Stahl, S. A. (2003). Fluency: A review of developmental and remedial practices. Journal of Educational Psychology, 95, 3-21.

LaBerge, D. \& Samuels, S. J. (1974). Toward a theory of automaticity information processing in reading. Cognitive Psychology, 6, 293-323.

Landerl, K., Fussenegger, B., Moll, K., \& Willburger, E. (2009). Dyslexia and dyscalculia: Two learning disorders with different cognitive profiles. Journal of Experimental Child Psychology, 103, 309-324.

Landerl, K. \& Moll, K. (2010). Comorbidity of learning disorders: Prevalence and familial transmission. Journal of Child Psychology and Psychiatry and Allied Disciplines, 51, 287-294.

Landerl, K., Ramus, F., Moll, K., Lyytinen, H., Leppänen, P. H., Lohvansuu, K., ... Schulte-Körne, G. (2013). Predictors of developmental dyslexia in European orthographies with varying complexity. Journal of Child Psychology and Psychiatry, 54, 686-694.

Landerl, K. \& Wimmer, H. (2008). Development of word reading fluency and spelling in a consistent orthography: An 8-year follow-up. Journal of Educational Psychology, 100, 150-161.

Leinonen, S., Müller, K., Leppänen, P. H. T., Aro, M., Ahonen, T., \& Lyytinen, H. (2001). Heterogeneity in adult dyslexic readers: Relating processing skills to the speed and accuracy of oral text reading. Reading and Writing: An Interdisciplinary Journal, 14, 265-296.

Lemoine, H., Levy, B. A., \& Hutchinson, A. (1993). Increasing the naming speed of poor readers: Representations formed across repetitions. Journal of Experimental Child Psychology, 55, 297-328.

Lepola, J., Poskiparta, E., Laakkonen, E., \& Niemi, P. (2005). Development of and relationship between phonological and motivational processes and naming speed in predicting word recognition in grade 1. Scientific Studies of Reading, 9, 367-399. 
Leppänen, U., Aunola, K., Niemi, P., \& Nurmi, J. E. (2008). Letter knowledge predicts grade 4 reading fluency and reading comprehension. Learning and Instruction, 18, 548-564.

Leppänen, U., Niemi, P., Aunola, K., \& Nurmi, J. E. (2006). Development of reading and spelling Finnish from preschool to grade 1 and grade 2. Scientific Studies of Reading, 10, 3-30.

Lervåg, A. \& Hulme, C. (2009). Rapid naming (RAN) taps a basic constraint on the development of early reading f luency. Psychological Science, 20, 10401048.

Levy, B. A., Abello, B., \& Lysynchuk, L. (1997). Transfer from word training to reading in context: Gains in reading fluency and comprehension. Learning Disability Quarterly, 20, 173-188.

Levy, B. A., Bourassa, D. C., \& Horn, C. (1999). Fast and slow namers: Benefits of segmentation and whole word training. Journal of Experimental Child Psychology, 73, 115-138.

Logan, J. A. R., Schatschneider, C., \& Wagner, R. (2011). Rapid serial naming and reading ability: The role of lexical access. Reading and Writing: An Interdisciplinary Journal, 24, 1-25.

Lovett, M. W., Steinbach, K. A., \& Frijters, J. C. (2000). Remediating the core deficits of developmental reading disability: A double deficit perspective. Journal of Learning Disabilities, 33, 334-358.

Lyytinen, H., Erskine, J., Tolvanen, A., Torppa, M., Poikkeus, A.-M. \& Lyytinen, P. (2006). Trajectories of reading development: A follow-up from birth to school age of children with and without risk for dyslexia. Merrill-Palmer Quarterly, 52, 514-546.

MacCallum, R. C., Zhang, S., Preacher, K. J., \& Rucker, D. D. (2002). On the practice of dichotomization of quantitative variables. Psychological Methods, 7, 19-40.

Maloney, E., Risko, E. F., O'Malley, S., \& Besner, D. (2009). Tracking the transition from sublexical to lexical processing: On the creation of orthographic and phonological lexical representations. The Quarterly Journal of Experimental Psychology, 62, 858-867.

Manis, F. R., Doi, L. M., \& Bhadha, B. (2000). Naming speed, phonological awareness, and orthographic knowledge in second graders. Journal of Learning Disabilities, 33, 325-333.

Manis, F. R., Seidenberg, M. S., \& Doi, L. M. (1999). See Dick RAN: Rapid naming and the longitudinal prediction of reading subskills in first and second graders. Scientific Studies of Reading, 3, 129-157.

Marinus, E., de Jong, P., \& van der Leij, A. (2012). Increasing word-reading speed in poor readers: No additional benefits of explicit letter-cluster training. Scientific Studies of Reading, 16, 166-185.

Mathes, P. G., Denton, C. A., Fletcher, J. M., Anthony, J. L., Francis, D. J., \& Schatschneider, C. (2005). The effects of theoretically different instruction and student characteristics on the skills of struggling readers. Reading Research Quarterly, 40, 148-182. 
Mazzocco, M. M. M. \& Grimm, K. J. (2013). Growth in rapid automatized naming from grades $\mathrm{K}$ to 8 in children with math or reading disabilities. Journal of Learning Disabilities, 46, 517-533.

McBride-Chang, C. \& Manis, F.R. (1996). Structural invariance in the associations of naming speed, phonological awareness, and verbal reasoning in good and poor readers: A test of the double deficit hypothesis. Reading and Writing: An Interdisciplinary Journal, 8, 323-339.

McCrory, E. J., Mechelli, A., Frith, U., \& Price, C. J. (2005). More than words: A common neural basis for reading and naming deficits in developmental dyslexia? Brain, 128, 261-267.

McGrath, L. M., Pennington, B. F., Shanahan, M. A., Santerre-Lemmon, L. E., Barnard, H. D., Willcutt, E. G., DeFries, J. C., \& Olson, R. K. (2011). A multiple deficit model of reading disability and attentiondeficit/hyperactivity disorder: Searching for shared cognitive deficits. Journal of Child Psychology and Psychiatry, 52, 547-557.

Meyer, M. S. \& Felton, R. H., (1999). Repeated reading to enhance fluency: Old approaches and new directions. Annals of Dyslexia, 49, 283-306.

Meyer, M.S., Wood, F.B., Hart, L.A., \& Felton, R.H. (1998). Selective predictive value of rapid automatized naming in poor readers. Journal of Learning Disabilities, 31, 106-117.

Miranda, A., Presentación, M. J., Siegenthaler, R., Colomer, C., \& Pinto, V. (2011). Comorbidity between attention deficit hyperactivity disorder and reading disabilities: Implications for assessment and treatment. Advances in Learning and Behavioral Disabilities, 24, 171-211.

Misra, M., Katzir, T., Wolf, M., \& Poldrack, R. A. (2004). Neural systems for rapid automatized naming in skilled readers: Unraveling the RANreading relationship. Scientific Studies of Reading, 8, 241-256.

Moll, K., Fussenegger, B., Willburger, E., \& Landerl, K. (2009). RAN is not a measure of orthographic processing. Evidence from the asymmetric German orthography. Scientific Studies of Reading, 13, 1-25.

Moll, K., Göbel, S. M., Gooch, D., Landerl, K., \& Snowling, M. J. (2014). Cognitive risk factors for specific learning disorder: Processing speed, temporal processing, and working memory. Journal of Learning Disabilities. Advance online publication. doi:10.1177/0022219414547221

Moll, K., Göbel, S. M., Snowling, M. J. (2014). Basic number processing in children with specific learning disorders: Comorbidity of reading and mathematics disorders. Child Neuropsychology: A Journal on Normal and Abnormal Development in Childhood and Adolescence. Advance online publication. doi:10.1080/09297049.2014.899570

Moll, K. \& Landerl, K. (2009). Double dissociation between reading and spelling deficits. Scientific Studies of Reading, 13, 359-382.

Moll, K., Ramus, F., Bartling, J., Bruder, J., Kunze, S., Neuhoff, N., ... Landerl, K. (2014). Cognitive mechanisms underlying reading and spelling development in five European orthographies. Learning and Instruction, 29, 65-77. 
Moore, C. J. \& Price, C. J. (1999). Three distinct ventral occipitotemporal regions for reading and object naming. Neuroimage, 10, 181-192.

Morgan, P. L. \& Fuchs, D. (2007). Is there a bidirectional relationship between children's reading skills and reading motivation? Council for Exceptional Children, 73, 165-183.

Morris, R. D., Stuebing, K. K., Fletcher, J. M., Shaywitz, S. E., Lyon, G. R., Shankweiler, D. P., Katz, L., Francis, D. J., \& Shaywitz, B. A. (1998). Subtypes of reading disability: Variability around a phonological core. Journal of Educational Psychology, 90, 347-373.

Naples, A. J., Chang, J. T., Katz, L., \& Grigorenko, E. L. (2009). Same or different? Insights into the etiology of phonological awareness and rapid naming. Biological Psychology, 80, 226-239.

National Institute of Child Health and Human Development (2000). Report of the National Reading Panel. Teaching children to read: An evidence-based assessment of the scientific research literature on reading and its implications for reading instruction. NIH Publication No. 00-4769. Washington, DC: U.S. Government Printing Office.

Nelson, J. R., Benner, G. J., \& Gonzalez, J. (2003). Learner characteristics that influence the treatment effectiveness of early literacy interventions: A meta-analytic review. Learning Disabilities Research \& Practice, 18, 255-267.

Neuhaus, G., Foorman, B. R., Francis, D. J., \& Carlson, C. D. (2001). Measures of information processing in rapid automatized naming (RAN) and their relation to reading. Journal of Experimental Child Psychology, 78, 359-373.

Nicolson, R. I. \& Fawcett, A. J. (1990). Automaticity: A new framework for dyslexia research. Cognition, 35, 159-182.

Nicolson, R. I., Fawcett, A. J., \& Dean, P. (2001). Developmental dyslexia: The cerebellar deficit hypothesis. Trends in Neurosciences, 24, 508-511.

Nopola-Hemmi, J., Myllyluoma, B., Voutilainen, A., Leinonen, S., Kere, J., \& Ahonen, T. (2002). Familial dyslexia: Neurocognitive and genetic correlation in a large Finnish family. Developmental Medicine $\mathcal{E}$ Child Neurology, 44, 580-586.

Norton, E. S., Beach, S. B., \& Gabrieli, J. D. E. (2015). Neurobiology of dyslexia. Current Opinion in Neurobiology, 30, 73-78.

Norton, E. S., Black, J. M., Stanley, L. M., Tanaka, H., Gabrieli, J. D., Sawyer, C., \& Hoeft, F. (2014). Functional neuroanatomical evidence for the doubledeficit hypothesis of developmental dyslexia. Neuropsychologia, 61, 235246.

Norton, E. S., \& Wolf, M. (2012). Rapid automatized naming (RAN) and reading fluency: Implications for understanding and treatment of reading disabilities. Annual Review of Psychology, 63, 427-452.

Närhi, V. \& Ahonen, T. (1995). Reading disability with or without attention deficit hyperactivity disorder: Do attentional problems make a difference? Developmental Neuropsychology, 11, 337-349. 
Närhi, V., Ahonen, T., Aro, M., Leppäsaari, T., Korhonen, T. T., Tolvanen, A., \& Lyytinen, H. (2005). Rapid serial naming: Relations between different stimuli and neuropsychological factors. Brain and Language, 92, 45-57.

Pagliuca, G. \& Monaghan, P. (2010). Discovering large grain sizes in a transparent orthography: Insights from a connectionist model of Italian word naming. European Journal of Cognitive Psychology, 22, 813-835.

Papadopoulos, T.C., Georgiou, G., \& Kendeou, P. (2009). Investigating the double-deficit hypothesis in Greek: Findings from a longitudinal study. Journal of Learning Disabilities, 42, 528-547.

Parrila, R., Kirby, J. R., \& McQuarrie, L. (2004). Articulation rate, naming speed, verbal short-term memory, and phonological awareness: Longitudinal predictors of early reading development. Scientific Studies of Reading, 8, 326.

Pennington, B. F. (2006). From single to multiple deficit models of developmental disorders. Cognition, 101, 385-413.

Pennington, B. F., Cardoso-Martins, C., Green, P. A., \& Lefly, D. L. (2001). Comparing the phonological and double-deficit hypotheses for developmental dyslexia. Reading and Writing: An Interdisciplinary Journal, 14, 707-755.

Pennington, B. F., Willcutt, E., \& Rhee, S. H. (2005). Analyzing comorbidity. In R. V. Kail (Ed.), Advances in child development and behavior (Vol. 33, pp. 263304). Oxford: Elsevier.

Perea, M. \& Carreiras, M. (1998). Effects of syllable frequency and syllable neighbourhood frequency in visual word recognition. Journal of Experimental Psychology. Human Perception and Performance, 24, 134-144.

Perfetti, C. A. (1985). Reading ability. London: Oxford University Press.

Petrill, S. A., Deater-Deckard, K., Thompson, L. A., DeThorne, L. S., \& Schatschneider, C. (2006). Genetic and environmental effects of serial naming and phonological awareness on early reading outcomes. Journal of Educational Psychology, 98, 112-121.

Petrill, S. A., Hart, S. A., Harlaar, N., Logan, J., Justice, L. M., Schatschneider, C., Thompson, L., DeThorne, L. S., Deater-Deckard, K., Cutting, L. (2010). Genetic and environmental influences on the growth of early reading skills. Journal of Child Psychology and Psychiatry, 51, 660-667.

Poulsen, M., Juul, H., \& Elbro, C. (2015). Multiple mediation analysis of the relationship between rapid naming and reading. Journal of Research in Reading, 38, 124-140.

Powell, D., Stainthorp, R., \& Stuart, M. (2014). Deficits in orthographic knowledge in children poor at rapid automatized naming (RAN) tasks? Scientific Studies of Reading, 18, 192-207.

Powell, D., Stainthorp, R., Stuart, M., Garwood, H., \& Quinlan, P. (2007). An experimental comparison between rival theories of rapid automatized naming performance and its relationship to reading. Journal of Experimental Child Psychology, 98, 46-68. 
Protopapas, A. \& Skaloumbakas, C. (2007). Traditional and computer-based screening and diagnosis of reading disabilities in Greek. Journal of Learning Disabilities, 40, 15-36.

Puolakanaho, A., Ahonen, T., Aro, M., Eklund, K., Leppänen, P. H. T., Poikkeus, A.-M., Tolvanen, A., Torppa, M., \& Lyytinen, H. (2007). Very early phonological and language skills: Estimating individual risk of reading disability. Journal of Child Psychology and Psychiatry, and Allied Disciplines, 48, 923-931.

Puolakanaho, A., Ahonen, T., Aro, M., Eklund, K., Leppänen, P. H. T., Poikkeus, A.-M., Tolvanen, A., Torppa, M., \& Lyytinen, H. (2008). Developmental links of very early phonological and language skills to second grade reading outcomes: Strong to accuracy but only minor to fluency. Journal of Learning Disabilities, 41, 353-370.

Raberger, T. \& Wimmer, H. (2003). On the automaticity/cerebellar deficit hypothesis of dyslexia: Balancing and continuous rapid naming in dyslexic and ADHD children. Neuropsychologia, 41, 1493-1497.

Raghubar, K. P., Barnes, M. A., \& Hecht, S. A. (2010). Working memory and mathematics: A review of developmental, individual difference, and cognitive approaches. Learning and Individual Differences, 20, 110-122.

Ramus, F. (2014). Neuroimaging sheds new light on the phonological deficit in dyslexia. Trends in cognitive sciences, 18, 274-275.

Ramus, F. \& Szenkovits, G. (2008). What phonological deficit? The Quarterly Journal of Experimental Psychology, 61, 129-141.

Regtvoort, A. G. F. M. \& van der Leij, A. (2007). Early intervention with children with dyslexic parents: Effects of a computerbased reading instruction at home on literacy acquisition. Learning and Individual Differences, 17, 35-53.

Reiter, B. A. (2001). Reading disabilities related to word recognition: Underlying deficits and diagnostic approaches. Canadian Journal of School Psychology, $17,65-84$.

Reynvoet, B., Brysbaert, M., \& Fias, W. (2002). Semantic priming in number naming. The Quarterly Journal of Experimental Psychology: Section A, 55, 1127-1139.

Roman, A. A., Kirby, J. R., Parrila, R., Wade-Woolley, L., \& Deacon, S.H. (2009). Towards a comprehensive view of the skills involved in word reading in grades 4, 6, and 8. Journal of Experimental Child Psychology, 102, 96-113.

Rubenstein, K. B., Raskind, W. H., Berninger, V. W., Matsushita, M. M., \& Wijsman, E. M. (2014). Genome scan for cognitive trait loci of dyslexia: Rapid naming and rapid switching of letters, numbers, and colors. American Journal of Medical Genetics Part B: Neuropsychiatric Genetics, 165, $345-356$.

Rucklidge, J. J. \& Tannock, R. (2002). Neuropsychological profiles of adolescents with ADHD: Effects of reading difficulties and gender. Journal of Clinical Psychology and Psychiatry, 43, 988-1003.

Salmi, P. (2008). Nimeäminen ja lukemisvaikeus: Kehityksen ja kuntoutuksen näkökulma [Naming and dyslexia: Developmental and training 
perspectives]. Jyväskylä Studies in Education, Psychology and Social Research, 345.

Samuelsson, S., Olson, R., Wadsworth, S., Corley, R., DeFries, J. C., Willcutt, E., Hulslander, J., \& Byrne, B. (2007). Genetic and environmental influences on prereading skills and early reading and spelling development in the United States, Australia, and Scandinavia. Reading and Writing, 20, 51-75.

Savage, R. \& Frederickson, N. (2005). Evidence of a highly specific relationship between rapid automatic naming of digits and textreading speed. Brain and Language, 93, 152-159.

Savage, R. S. \& Frederickson, N. (2006). Beyond phonology: What else is needed to describe the problems of below-average readers and spellers? Journal of Learning Disabilities, 39, 399-413.

Savage, R. S., Frederickson, N., Goodwin, R., Patni, U., Smith, N., \& Tuersley, L. (2005). Relationships among rapid digit naming, phonological processing, motor automaticity, and speech perception in poor, average, and good readers and spellers. Journal of Learning Disabilities, 38, 12-28.

Savage, R., Pillay, V., \& Melidona, S. (2007). Deconstructing rapid automatized naming: Component processes and the prediction of reading difficulties. Learning and Individual Differences, 17, 129-146.

Savage, R., Pillay, V., \& Melidona, S. (2008). Rapid serial naming is a unique predictor of spelling in children. Journal of Learning Disabilities, 41, 235-250.

Scammacca, N., Roberts, G., Vaughn. S., Edmonds, M., Wexler, J., Reutebuch, C. K., \& Torgesen, J. K. (2007), Interventions for adolescent struggling readers: A meta-analysis with implications for practice. Portsmouth, NH: RMC Research Corporation, Center on Instruction.

Scarborough, H. S. (1998). Predicting the future achievement of second graders with reading disabilities: Contributions of phonemic awareness, verbal memory, rapid naming, and IQ. Annals of Dyslexia, 48, 115-136.

Schatschneider, C., Carlson, C. D., Francis, D. J., Foorman, B. F., \& Fletcher, J. M. (2002). Relationship of rapid automatized naming and phonological awareness in early reading development: Implications for the doubledeficit hypothesis. Journal of Learning Disabilities, 35, 245-256.

Schatschneider, C., Fletcher, J. M., Francis, D. J., Carlson, C. D., \& Foorman, B. R. (2004). Kindergarten prediction of reading skills: A longitudinal comparative analysis. Journal of Educational Psychology, 96, 265-282.

Scheltinga, F., van der Leij, A., \& Struiksma, A. J. C. (2010). Predictors of response to intervention of word reading fluency in Dutch. Journal of Learning Disabilities, 43, 212-228.

Schwanenflugel, P. J., Meisinger, E. B., Wisenbaker, J. M., Kuhn, M. R., Strauss, G. P., \& Morris, R. D. (2006). Becoming a fluent and automatic reader in the early elementary school years. Reading Research Quarterly, 41, 496-522.

Semrud-Clikeman, M., Guy, K., Griffin, J. D., \& Hynd, G. W. (2000). Rapid naming deficits in children and adolescents with reading disabilities and attention deficit hyperactivity disorder. Brain $\mathcal{E}$ Language, 74, 70-83. 
Serrano, F. \& Defior, S. (2008). Dyslexia speed problems in a transparent orthography. Annals of Dyslexia, 58, 81-95.

Sexton, C. C., Gelhorn, H. L., Bell, J. A., \& Classi, P. M. (2012). The cooccurrence of reading disorder and ADHD: Epidemiology, treatment, psychosocial impact, and economic burden. Journal of Learning Disabilities, 45, 538-564.

Seymour, P. H. K., Aro, M. \& Erskine, J. M. (2003). Foundation literacy acquisition in European orthographies. British Journal of Psychology, 94, 143-174.

Share, D. L. (1995). Phonological recoding and self-teaching: Sine qua non of reading acquisition. Cognition, 55, 151-218.

Share, D. L. (2008). On the Anglocentricities of current reading research and practice: The perils of overreliance on an "outlier" orthography. Psychological Bulletin, 134, 584-615.

Soriano, M., Miranda, A., Soriano, E., Nievas, F., \& Felix, V. (2011). Examining the efficacy of an intervention to improve fluency and reading comprehension in spanish children with reading disabilities. International Journal of Disability, Development and Education, 58, 47-59.

Spector, J. E. (2005). Instability of double-deficit subtypes among at-risk first grade readers. Reading Psychology, 26, 285-312.

Sprugevica, I. \& Høien, T. (2003). Early phonological skills as a predictor of reading acquisition: A follow-up study from kindergarten to the middle of grade 2. Scandinavian Journal of Psychology, 44, 119-124.

Sprugevica, I. \& Høien, T. (2004). Relations between enabling skills and reading comprehension: A follow-up study of Latvian students from first to second grade. Scandinavian Journal of Psychology, 45, 115-122.

Stage, S.A., Abbott, R.D., Jenkins, J.R., \& Berninger, V.W. (2003). Predicting response to early instruction from verbal IQ, reading related language abilities, attention ratings, and verbal IQ reading discrepancy. Journal of Learning Disabilities, 36, 24-33.

Stainthorp, R. (2014). Dyslexia and remediation/education: Where next? Current Developmental Disorders Reports, 1, 260-266.

Stainthorp, R., Stuart, M., Powell, D., Quinlan, P., \& Garwood, H. (2010). Visual processing deficits in children with slow RAN performance. Scientific Studies of Reading, 14, 266-292.

Stanovich, K. E. \& Siegel, L. S. (1994). Phenotypic performance profile of children with reading disabilities: A regression-based test of the phonological-core variable-difference model. Journal of Educational Psychology, 86, 24-53.

Steacy, L. M., Kirby, J. R., Parrila, R., \& Compton, D. L. (2014). Classification of double deficit groups across time: An analysis of group stability from kindergarten to second Grade. Scientific Studies of Reading, 18, 255-273.

Stringer, R. W., Toplak, M. E., \& Stanovich, K. E. (2004). Differential relationships between RAN performance, behaviour ratings, and 
executive function measures: Searching for a double dissociation. Reading and Writing, 17, 891-914.

Suggate, S. P. (2014). A meta-analysis of the long-term effects of phonemic awareness, phonics, fluency, and reading comprehension interventions. Journal of Learning Disabilities. Advance online publication. doi:10.1177/0022219414528540

Sunseth, K. \& Bowers, P.G. (2002). Rapid naming and phonemic awareness: Contributions to reading, spelling, and orthographic knowledge. Scientific Studies of Reading, 6, 401-429.

Swanson, H. L., Jerman, O., \& Zheng, X. (2009). Math disabilities and reading disabilities: Can they be separated? Journal of Psychoeducational Assessment, $42,260-287$.

Swanson, H. L., Trainin, G., Necoechea, D. M., \& Hammill, D. D. (2003). Paid naming, phonological awareness, and reading: A meta-analysis of the correlation evidence. Review of Educational Research, 73, 407-440.

Tannock, R., Martinussen, R., \& Frijters, J. (2000). Naming speed performance and stimulant effects indicate effortful, semantic processing deficits in attention-deficit/hyperactivity disorder. Journal of Abnormal Child Psychology, 28, 237-252.

Thaler, V., Ebner, E. M., Wimmer, H., \& Landerl, K. (2004). Training reading fluency in dysfluent readers with high reading accuracy: Word specific effects but low transfer to untrained words. Annals of Dyslexia, 54, 89-113.

Therrien, W. (2004). Fluency and comprehension gains as a result of repeated reading: A meta-analysis. Remedial and Special Education, 25, 252-261.

Thomson, J. B., Chenault, B., Abbot, R. D., Raskind, W. H., Richards, T., Aylward, E., \& Berninger, V. W. (2005). Converging evidence for attentional influences on the orthographic word form in child dyslexics. Journal of Neurolinguistics, 18, 93-126.

Torgesen, J. K., Alexander, A. W., Wagner, R. K., Rashotte, C. A., Voeller, K., \& Conway, T. (2001). Intensive remedial instruction for children with severe reading disabilities: Immediate and long-term outcomes from two instructional approaches. Journal of Learning Disabilities, 34, 33-58.

Torgesen, J. K., Wagner, R. K., Rashotte, C. A., Burgess, S., \& Hecht, S. (1997). Contributions of phonological awareness and rapid automatized naming ability to growth of word-reading skills in second- to fifth-grade children. Scientific Studies of Reading, 1, 161-185.

Torppa, M., Georgiou, G., Salmi, P., Eklund, E., Lyytinen, H. (2012) Examining the double-deficit hypothesis in an orthographically consistent language. Scientific Studies of Reading, 16, 287 - 315.

Torppa, M., Lyytinen, P., Erskine, J., Eklund, K., \& Lyytinen, H. (2010) Language development, literacy skills, and predictive connections to reading in Finnish children with and without familial risk for dyslexia. Journal of Learning Disabilities 43, 308-321.

Torppa, M., Parrila, R., Niemi, P., Lerkkanen, M.-K., Poikkeus, A.-M., \& Nurmi, J.-E. (2013). The double-deficit hypothesis in the transparent Finnish 
orthography: a longitudinal study from kindergarten to grade 2. Reading and Writing, 26, 1353-1380.

Torppa, M., Poikkeus, A. M., Laakso, M. L., Eklund, K., \& Lyytinen, H. (2006). Predicting delayed letter knowledge development and its relation to grade 1 reading achievement among children with and without familial risk for dyslexia. Developmental Psychology, 42, 1128-1142.

Torppa, M., Tolvanen, A., Poikkeus, A. M., Eklund, K., Lerkkanen, M. K., Leskinen, E., \& Lyytinen, H. (2007). Reading development subtypes and their early characteristics. Annals of Dyslexia, 57, 3-32.

Tressoldi, P. E., Vio, C., \& Iozzino, R. (2007). Efficacy of an intervention to improve fluency in children with developmental dyslexia in a regular orthography. Journal of Learning Disabilities, 40, 203-209.

Vadasy, P. F., Sanders, E. A., \& Abbott, R. D. (2008). Effects of supplemental early reading intervention at 2-year follow up: Reading skill growth patterns and predictors. Scientific Studies of Reading, 12, 51-89.

Vaessen, A., Bertrand, D., Tóth, D., Csépe, V., Faísca, L., Reis, A., \& Blomert, L. (2010). Cognitive development of fluent word reading does not qualitatively differ between transparent and opaque orthographies. Journal of Educational Psychology, 102, 827-842.

Vaessen, A. \& Blomert, L. (2010). Long-term cognitive dynamics of fluent reading development. Journal of Experimental Child Psychology, 105, 213-231.

Vaessen, A., Gerretsen, P., \& Blomert, L. (2009). Naming speed problems do not reflect a second independent core deficit in dyslexia: Double deficits explored. Journal of Experimental Child Psychology, 103, 202-221.

van Bergen, E., de Jong, P. F., Maassen, B., \& van der Leij, A. (2014). The effect of parents' literacy skills and children's preliteracy skills on the risk of dyslexia. Journal of Abnormal Child Psychology, 42, 1187-1200.

van den Boer, M., van Bergen, E., \& de Jong, P. F. (2014). Underlying skills of oral and silent reading. Journal of Experimental Child Psychology, 128, 138151.

van den Bos, K. P., Zijlstra, B. J. H., \& Spelberg, H. C. I. (2002). Life-span data on continuous-naming speeds of numbers, letters, colors, and pictured objects, and word-reading speed. Scientific Studies of Reading, 6, 25-49.

van der Leij, A. (2013). Dyslexia and early intervention: What did we learn from the Dutch Dyslexia Programme? Dyslexia, 19, 241-255.

van der Sluis, S., de Jong, P. F., \& Leij, A. V. D. (2004). Inhibition and shifting in children with learning deficits in arithmetic and reading. Journal of Experimental Child Psychology, 87, 239-266.

Vaughn, S., Linan-Thompson, S., \& Hickman, P. (2003). Response to instruction as a means of identify students with reading/learning disabilities. Exceptional Children, 69, 391-409.

Vellutino, F. R., Fletcher, J. M., Snowling, M. J., \& Scanlon, D. M. (2004). Specific reading disability (dyslexia). What have we learned in the past four decades? Journal of Child Psychology and Psychiatry, 45, 2-40. 
Vukovic, R. K. \& Siegel, L. (2006). The double-deficit hypothesis: A comprehensive analysis of the evidence. Journal of Learning Disabilities, 39, $25-47$.

Waber, D. P., Forbes, P. W., Wolff, P. H., \& Weiler, M. D. (2004). Neurodevelopmental characteristics of children with learning impairments classified according to the double-deficit hypothesis. Journal of Learning Disabilities, 37, 451-461.

Waber, D. P., Wolff, P. H., Forbes, P. W., \& Weiler, M. D. (2000). Rapid automatized naming in children referred for evaluation of heterogeneous learning problems: How specific are naming speed deficits to reading disability? Child Neuropsychology, 6, 251-261.

Wagner, R. K. \& Torgesen, J. K. (1987). The nature of phonological processing and its causal role in the acquisition of reading skills. Psychological Bulletin, 101, 192-212.

Wagner, R. K., Torgesen, J. K., Rashotte, C. A., Hecht, S. A., Barker, T. A., Burgess, S. R., Donahue, S. R., \& Garon, T. (1997). Changing relations between phonological processing abilities and word-level reading as children develop from beginning to skilled readers: A 5-year longitudinal study. Developmental Psychology, 33, 468-479.

Walsh, D., Price, G., \& Gillingham, M. (1988). The critical but transitory importance of letter naming. Reading Research Quarterly, 23, 108-122.

Wanzek, J., Vaughn, S., Scammacca, N. K., Metz, K., Murray, C. S., Roberts, G., \& Danielson, L. (2013). Extensive reading interventions for students with reading difficulties after grade 3. Review of Educational Research, 83, 163195.

Wentink, H., Van Bon, W., \& Schreuder, R. (1997). Training of poor readers' phonological decoding skills: Evidence for syllable-bound processing. Reading and Writing: An Interdisciplinary Journal, 9, 163-192.

Wiig, E. H., Zureich, P., \& Chan, H. N. H. (2000). A clinical rationale for assessing rapid automatized naming in children with language disorders. Journal of Learning Disabilities, 33, 359-374.

Willburger, E., Fusseneger, B., Moll, K., Wood, G., \& Landerl, K. (2008). Naming speed in dyslexia and dyscalculia. Learning and Individual Differences, 18, 224-236.

Willcutt, E. G., Betjemann, R. S., McGrath, L. M., Chhabildas, N. A., Olson, R. K., DeFries, J. C., \& Pennington, B. F. (2010). Etiology and neuropsychology of comorbidity between RD and ADHD: The case for multiple-deficit models. Cortex, 46, 1345-1361.

Willcutt, E. G., Pennington, B. F., Duncan, L., Smith, S. D., Keenan, J. M., Wadsworth, S., DeFries, J. C., \& Olson, R. K. (2010). Understanding the complex etiologies of developmental disorders: Behavioral and molecular genetic approaches. Journal of Developmental \& Behavioral Pediatrics, 31, 533-544.

Willcutt, E. G., Petrill, S. A., Wu, S., Boada, R., DeFries, J. C., Olson, R. K., \& Pennington, B. F. (2013). Comorbidity between reading disability and 
math disability concurrent psychopathology, functional impairment, and neuropsychological functioning. Journal of Learning Disabilities, 46, 500-516.

Wilson, A. J., Andrewes, S. G., Struthers, H., Rowe, V. M., Bogdanovic, R., \& Waldie, K. E. (in press). Dyscalculia and dyslexia in adults: Cognitive bases of comorbidity. Learning and Individual Differences, 37, 118-132.

Wimmer, H. (1993). Characteristics of developmental dyslexia in a regular writing system. Applied Psycholinguistics, 14, 1-33.

Wimmer, H. \& Mayringer, H. (2002). Dysfluent reading in the absence of spelling difficulties: A specific disability in regular orthographies. Journal of Educational Psychology, 94, 272-277.

Wimmer, H., Mayringer, H., \& Landerl, K. (1998). Poor reading: A deficit in skill-automatization or a phonological deficit? Scientific Studies of Reading, 2, 321-340.

Wimmer, H., Mayringer, H., \& Landerl, K. (2000). The doubledeficit hypothesis and difficulties in learning to read a regular orthography. Journal of Educational Psychology, 92, 668-680.

Wimmer, H., Mayringer, H., \& Raberger, T. (1999). Reading and dual-task balancing: Evidence against the automatization deficit explanation of developmental dyslexia. Journal of Learning Disabilities, 32, 473-478.

Wise, J. C., Pae, H. K., Wolfe, C. B., Sevcik, R. A., Morris, R. D., Lovett, M., \& Wolf, M. (2008). Phonological awareness and rapid naming skills of children with reading disabilities and children with reading disabilities who are at risk for mathematics difficulties. Learning Disabilities Research $\mathcal{E}$ Practice, 23, 125-136.

Wise, J. C., Sevcik, R. A., Morris, R. D., Lovett, M. W., Wolf, M., Kuhn, M., Meisinger, B., \& Schwanenflugel, P. (2010). The relationship between different measures of oral reading fluency and reading comprehension in second-grade students who evidence different oral reading fluency difficulties. Language, Speech, and Hearing Services in Schools, 41, 340-348.

Wolf, M. (1986). Rapid alternating stimulus naming in the developmental dyslexias. Brain and Language, 27, 360-379.

Wolf, M. (1999). What time may tell: Towards a new conceptualization of developmental dyslexia. Annals of Dyslexia, 49, 1-28.

Wolf, M., Bally, H., \& Morris, R. (1986). Automaticity, retrieval processes, and reading: A longitudinal study in average and impaired readers. Child Development, 57, 988-1000.

Wolf, M. \& Bowers, P. G. (1999). The double-deficit hypothesis for the developmental dyslexias. Journal of Educational Psychology, 91, 415-438.

Wolf, M., Bowers, P. G., \& Biddle, K. (2000). Naming-speed processes, timing, and reading: A conceptual review. Journal of Learning Disabilities, 33, 387407.

Wolf, M. \& Katzir-Cohen, T. (2001). Reading fluency and its intervention. Scientific Studies of Reading, 5, 211-239. 
Wolf, M., Miller, L., \& Donnelly, K. (2000). Retrieval, automaticity, vocabulary elaboration, orthography (RAVE-O): A comprehensive, fluency-based reading intervention program. Journal of Learning Disabilities, 33, 375-386.

Wolff, P. H., Michel, G., \& Ovrut, M. (1990a). Rate and timing precision of motor coordination in developmental dyslexia. Developmental Psychology, 26, 349-359.

Wolff, P. H., Michel, G., \& Ovrut, M. (1990b). The timing of syllable repetitions in developmental dyslexia. Journal of Speech-Language-Hearing, 33, 281-289.

Wolff, P. H., Michel, G., \& Ovrut, M. (1990c). Rate variables and automatized naming in developmental dyslexia. Brain and Language, 39, 556-575.

Wolff, U. (2014). RAN as a predictor of reading skills, and vice versa: results from a randomised reading intervention. Annals of Dyslexia, 64, 151-165.

Yap, R. \& van der Leij, A. (1993). Word processing in dyslexics: An automatic decoding deficit? Reading and Writing: An Interdisciplinary Journal, 5, 261279.

Yap, R. L. \& van der Leij, A. (1994). Testing the automatization deficit hypothesis of dyslexia via a dual-task paradigm. Journal of Learning Disabilities, 27, 660-665.

Young, A. \& Bowers, P. G. (1995). Individual difference and text difficulty determinants of reading fluency and expressiveness. Journal of Experimental Child Psychology, 60, 428-454.

Ziegler, J. C., Bertrand, D., Tóth, D., Csépe, V., Reis, A., Faísca, L., ...? \& Blomert, L. (2010). Orthographic depth and its impact on universal predictors of reading: a cross-language investigation. Psychological Science, 21, 551-559.

Ziegler, J. C. \& Goswami, U. (2005). Reading acquisition, developmental dyslexia, and skilled reading across languages: A psycholinguistic grain size theory. Psychological Bulletin, 131, 3-29.

Ziegler, J. C., Pech-Georgel, C., Dufau, S., \& Grainger, J. (2010). Rapid processing of letters, digits and symbols: What purely visual-attentional deficit in developmental dyslexia? Developmental Science, 13, F8-F14.

Ziegler, J. C., Perry, C., Ma-Wyatt, A., Ladner, D., \& Schulte-Körne, G. (2003). Developmental dyslexia in different languages: Language-specific or universal?. Journal of Experimental Child Psychology, 86, 169-193.

Zoccolotti, P., De Luca, M., Di Filippo, G., Judica, A., \& Martelli, M. (2009). Reading development in an orthographically regular language: Effects of length, frequency, lexicality and global processing ability. Reading and Writing, 22, 1053-1079.

Zoccolotti, P., De Luca, M., Di Pace, E., Judica, A., Orlandi, M., \& Spinelli, D. (1999). Markers of developmental surface dyslexia in a language (Italian) with high grapheme-phoneme correspondence. Applied Psycholinguistics, 20, 191-216.

Zoccolotti, P., De Luca, M., Lami, L., Pizzoli, C., Pontillo, M., \& Spinelli, D. (2013). Multiple stimulus presentation yields larger deficits in children with developmental dyslexia: A study with reading and RAN-type tasks. Child Neuropsychology, 19, 639-647. 
Zoccolotti, P., De Luca, M., Marinelli, C. V., \& Spinelli, D. (2014). Modeling individual differences in text reading fluency a different pattern of predictors for typically developing and dyslexic readers. Frontiers in Psychology, 5, 1374. doi:10.3389/fpsyg.2014.01374 


\title{
ORIGINAL PAPERS
}

\section{I \\ RAPID AUTOMATIZED NAMING AND LEARNING DISABILITIES: DOES RAN HAVE A SPECIFIC CONNECTION TO READING OR NOT?}

\author{
by \\ Riikka Heikkilä, Vesa Närhi, Mikko Aro, \& TimoAhonen, 2009 \\ Child Neuropsychology, 15, 343 - 358.
}

Reproduced with kind permission by Taylor \& Francis Group. 


\title{
RAPID AUTOMATIZED NAMING AND LEARNING DISABILITIES: DOES RAN HAVE A SPECIFIC CONNECTION TO READING OR NOT?
}

\author{
Riikka Heikkilä, ${ }^{1}$ Vesa Närhi, ${ }^{1}$ Mikko Aro, ${ }^{1}$ and Timo Ahonen ${ }^{2}$ \\ ${ }^{1}$ Niilo Mäki Institute, Jyväskylä, Finland, and ${ }^{2}$ Niilo Mäki Institute and University \\ of Jyväskylä, Finland
}

This work is an extension of a study by Waber, Wolff, Forbes, and Weiler (2000) in which the specificity of naming speed deficits to reading disability (RD) was examined. One hundred ninety-three children (ages 8 to 11) evaluated for learning disabilities were studied. It was determined how well rapid automatized naming (RAN) discriminated between different diagnostic groups (learning impaired [LI] with and without RD) from controls and from each other. Whereas Waber et al. concluded that $R A N$ was an excellent tool for detecting risk for learning disabilities in general, the results of the present study point to a more specific connection between $R A N$ and $R D$.

Keywords: Rapid naming; Learning disabilities; Reading disabilities; Comorbidity.

Growing research evidence supports the view that one of the background skills affecting reading is rapid automatized naming (RAN); the ability to recall names of serially presented familiar objects or symbols. Naming speed deficits (NSD) is the term used to describe slow and laborious recall of familiar objects, especially when presented as serial stimuli (for review of rapid naming, see Bowers \& Newby-Clark, 2002; Vukovic \& Siegel, 2006; Wolf, Bowers, \& Biddle, 2000).

Most of the research within rapid naming has taken place within the framework of dyslexia and reading research. Indeed, in various studies rapid naming has been connected to reading accuracy (e.g., Spring \& Davis, 1988), reading speed (e.g., Berninger, Abbott, Thomson, \& Raskind, 2001; Wimmer, 1993; Young \& Bowers, 1995) and reading comprehension, either directly (Badian, 1993; Sprugevica \& Høien, 2004) or via laborious word decoding (Spring \& Davis).

In the context of reading and language, the connections of rapid naming to phonological skills (e.g., Wolf et al., 2000) and to orthographic knowledge (e.g., Bowers, Golden, Kennedy, \& Young, 1994; Manis, Doi, \& Bhadha, 2000) have been studied, as has RAN's connection to broader skill areas like general processing speed (Kail, Hall, \&

The research was supported by Finnish Slot Machine Association. We are grateful to Peter Forbes for assisting with the statistical methods and data used in the article by Waber et al. The authors would also like to acknowledge Rauno Parrila for the comments on the article and Michael Freeman for his assistance with revising the language.

Address correspondence to Mrs. Riikka Heikkilä, Niilo Mäki Institute, P.O. Box 35, University of Jyväskylä, 40014 Finland. E-mail: riikka.heikkila@nmi.fi 
Caskey, 1999). The results of these studies vary widely, and many of the conclusions are contradictory. Despite speculation on its connections to several cognitive abilities, it seems, however, that naming speed is not connected to general intelligence (Bowers, Steffy, \& Tate, 1988; Denckla \& Rudel, 1976; Meyer, Wood, Hart, \& Felton, 1998). Alongside the many hypotheses concerning the link between individual skills and RAN are studies that support an eclectic view according to which RAN is best seen as a multicomponential skill that has connections with many background skills (Denckla \& Cutting, 1999; Närhi et al., 2005; Wolf et al., 2000).

Because RAN can be measured before reading instruction begins, the strong findings on its reading-related predictive power has made RAN one of the most useful tools for predicting children at risk for reading difficulties (De Jong \& Van der Leij, 2003; Puolakanaho et al., 2007). RAN has also been found to predict reading disabilities at school age (e.g., Korhonen, 1995; Manis, Doi, \& Bhadha, 2000; Scarborough, 1998) and to differentiate children with a reading disability (RD) from controls without a RD (Denckla \& Rudel, 1976; O’Malley, Francis, Foorman, Fletcher, \& Swank, 2002; Wolf, 1986). Differences between RD and control groups seem to occur also in adulthood (Vukovic, Wilson, \& Nash, 2004).

Despite suggestions that naming speed could serve as a diagnostic measure of reading at school age (Carver, 1991; Davis \& Spring, 1990), print-based diagnostic tests have been developed that are more effective than RAN in discriminating RD children from non-RD children (Hammill, 2004), and RAN has not always fulfilled the criteria for an acceptable measure for clinical use (Hammill, Mather, Allen, \& Roberts, 2002). Therefore one of the suggestions for the primary clinical use of a RAN test is to use it as a predictor of reading performance before reading instruction begins (Reiter, 2001; Wolf et al., 2000) and during school age as one of the tools for exploring the background of reading disabilities more thoroughly (Hammill).

When exploring RAN in the context of learning disabilities, children with learning disabilities without RD have been faster namers than children with RD (Denckla \& Rudel, 1976; Denckla, Rudel, \& Broman, 1981; Ho, Chan, Leung, Lee, \& Tsang, 2005). Comparisons between different kinds of learning disabilities have been rare and most of the studies of rapid naming have focused on reading, language impairments, or specific learning problems such as attention deficit/hyperactivity disorder (ADHD) or arithmetic disabilities. One of the few studies that has pointed to a connection between RAN and learning disabilities in general is the original study by Denckla and Rudel in which a specific connection between RAN and dyslexia was found. They also noticed that learning-impaired children without dyslexia were slower namers than control children.

In the studies on RAN that focus on learning disabilities other than RD support has been found for the view that rapid naming is connected to arithmetic disabilities (Van der Sluis, De Jong, \& van der Leij, 2004), number fact disorders (Temple \& Sherwood, 2002), and calculation fluency (Koponen, Aunola, Ahonen, \& Nurmi, 2007; Koponen, Mononen, Räsänen, \& Ahonen, 2006); while in other studies the connection between rapid naming and arithmetic skills has not been unambiguously supported (De Jong \& Van der Leij, 1999).

The connection between rapid naming and attention has been studied as well, also with mixed results. In comparisons between children with attention problems and children with reading disabilities, most studies have found children with $\mathrm{RD}$ to be slower namers than children with attention problems (Felton, Wood, Brown, Campbell, \& Harter, 1987; Närhi \& Ahonen, 1995), and poor performance in rapid naming has been found to be associated with RD and not ADHD (Felton \& Wood, 1989; Raberger \& Wimmer, 2003). However, results may be affected by the type of attention problem. When comparing children with 
ADHD-inattentive type with children with ADHD-hyperactive type, the former group has been significantly slower in rapid naming than the latter (Hynd et al., 1991; Thomson et al., 2005).

With the aim of addressing the issue of rapid naming and learning disabilities in general, Waber, Wolff, Forbes, and Weiler (2000) studied the specificity of naming speed deficits (NSD) in relation to reading disability (RD) in 188 children (ages 7 to 11 years) referred for evaluation of learning disabilities (RD, ADHD-inattentive type, and mathematics disability). In their study, RAN differentiated children with RD from the control children very effectively. However, RAN was not as effective in differentiating children with RD from learning-impaired (LI) children without RD (non-RD). In addition, RAN also differentiated learning impaired non-RD children from controls; although not as effectively as children with RD from controls (the discriminating power was of about the same size as in the RD versus non-RD comparison). It also seemed that in their sample of LI children, the prevalence of NSD increased with the comorbidity of different learning disabilities but was not dependent on the type of diagnosis. The authors concluded that RAN was an excellent tool for detecting learning impairment in general but was less effective in distinguishing RD children from other LI children. Waber et al. also studied the optimal cutoff score for RAN performance, i.e., that which would produce the greatest percentage of correct classifications. Determined in this way, $-1.0 S D$ from the mean of the control population seemed to be the best cutoff score.

The aim of this study was to extend the study by Waber et al. (2000) to see if their results on RAN's ability to detect learning impairments in general were confirmed among subjects from a different cultural and language background. The need for further study also arises from the fact that studies conducted with clinical samples often produce biased results and usually cannot be generalized without robust research evidence.

\section{METHODS}

\section{Participants}

The sample consisted of 193 children referred to a child neuropsychological clinic for evaluation of learning disabilities. The sample was the same as that used in the study by Närhi et al. (2005). Selection was made according to the following criteria: Finnish as the mother tongue, age 8-11 years, either verbal or performance Wechsler Intelligence Scale for Children-Revised edition (WISC-R; Wechsler, 1974) IQ of 80 or above, no acquired central nervous system damage, and no physical illness that had resulted in excessive absence from school. All the measures used in this study were administered to the children as part of the assessment. To cope with missing observations in the data (5.2\%), a real value imputation method was developed (for details on the method, see Närhi, Laaksonen, Hietala, Ahonen, \& Lyytinen, 2001).

All the children in the clinical group were affected by some form of learning or other school-related problem. The most common learning disabilities were Reading Disability (RD), Attention Deficits (AD), and Mathematics Disability (MD). All the children in the clinical sample were from middle-class families resident in the Central Finland area. The mean age of the LI sample was 9.6 years (standard deviation 1.0) and $76.6 \%$ of the sample were boys. Information on the cognitive ability and naming time scores of the clinical sample is presented in Table 1. As can be seen, there were differences in cognitive ability between the present sample and that of Waber et al. (2000); the present sample having significantly lower IQ. One should also note that while the naming 
Table 1 Mean Cognitive Ability of Referred Children and Rapid Automatized Naming in Learning Impaired and Control Groups in the Present Study and in Waber et al.

\begin{tabular}{|c|c|c|c|c|c|}
\hline \multirow[b]{2}{*}{ Measure $\left(N^{\mathrm{a}}\right)$} & \multicolumn{2}{|c|}{ Mean } & \multicolumn{2}{|c|}{ Standard deviation } & \multirow{2}{*}{$\begin{array}{c}\text { Difference } \\
T \text {-score }(d f)\end{array}$} \\
\hline & This study & Waber et al. & This study & Waber et al. & \\
\hline \multicolumn{6}{|l|}{ WISC $^{b}(193 / 188)$} \\
\hline Verbal IQ & 89.0 & 103.9 & 9.8 & 13.7 & $8.73(336)^{* * *}$ \\
\hline Performance IQ & 93.2 & 101.2 & 12.3 & 12.6 & $4.43(378) * * *$ \\
\hline Full Scale IQ & 90.0 & 102.7 & 8.6 & 11.8 & $8.57(340) * * *$ \\
\hline \multicolumn{6}{|c|}{ RAN score, LI sample ${ }^{c}(193 / 188)$} \\
\hline Letters & 38.0 & 35.5 & 14.5 & 12.5 & $1.81(374)$ \\
\hline Numbers & 41.1 & 37.9 & 23.3 & 12.5 & $1.66(232)$ \\
\hline \multicolumn{6}{|c|}{ RAN score, normative sample ${ }^{c}(119 / 115)$} \\
\hline Letters & 28.3 & 23.8 & 7.8 & 4.7 & $7.32(150) * * *$ \\
\hline Numbers & 30.1 & 24.0 & 8.0 & 5.6 & $8.80(131) * * *$ \\
\hline
\end{tabular}

Note. $\mathrm{LI}=$ Learning impaired; Difference $=$ Difference between studies on cognitive ability.

${ }^{\text {a }}$ The first $N$ gives the sample size in the present study and the second the sample size in Waber et al. ${ }^{\text {b} W I S C-R ~}$ was used in the present study and Wechsler Intelligence Scale for Children-Third edition (WISC-III; Wechsler, 1991) in Waber et al. ${ }^{\mathrm{c}}$ The information on the RAN-score statistics needed to compare the studies was received from Peter Forbes (Personal communication May 31, 2005).

$* * * p<.001$.

times were very comparable between the studies in LI groups, the control group of Waber et al. was significantly faster than the control group of this study. This may have effects on the prevalence of the NSD and also on the receiver operating characteristic (ROC) analyses, as discussed later.

\section{Design}

Reading disability (RD) was diagnosed separately for speed and accuracy on the basis of one of two text reading tests (as the test used at the clinic was changed during the data collection); one normed by grade and the other by age (Niilo Mäki Institute, 2004). The reading speed criterion for RD was $1.5 S D$ below the mean text reading rate for age or grade, and the accuracy criterion for RD was 1.5 SD below the mean percentage of correctly read words for age or grade. The RD diagnosis was based on text reading only; the discrepancy-based criterion used in Waber et al.'s study was not used in this study. For the analyses, the LI children not having RD were also grouped. Children not having RD by speed were assigned to a non-RD-speed group and children not having RD by accuracy were assigned to a non-RD-accuracy group. Because of the overlap between the RD groups, the non-RD-speed group contained children with RD-accuracy and the nonRD-accuracy group included some children with RD speed.

The presence of Attention Deficit (AD) was evaluated using a Child Behavior Checklist filled in by the child's parents (Achenbach, 1991a), or a Child Behavior ChecklistTeacher's Report Form filled in by the child's primary school teacher (Achenbach, 1991b). The criterion for AD was a $T$-score greater than 60 on the Attention scale on either the parental or teacher evaluation.

Mathematics disability (MD) was diagnosed using two tests. The primary test used was the RMAT, a standardized arithmetical test for 9-12 years-olds (Räsänen, 2004). 
If RMAT was not yet available, the Arithmetic subtest of Kaufman Assessment Battery for Children (K-ABC; Kaufman, 1983) was used with local normative data (Niilo Mäki Institute, 2004). For both measures, a cutoff of $1.5 S D$ below the normative group mean was used as the criterion for MD. Of the measures, the RMAT is time-limited accuracy measure and the Kaufman $\mathrm{ABC}$ is purely a measure of accuracy.

\section{Measures}

Rapid Automatized Naming (RAN). Rapid automatized naming was assessed using two stimulus cards, one containing letters and the other containing numbers. Each of the stimulus cards consisted of five different items, each replicated 10 times. The items were arranged in a fixed pseudo-random order, so that no individual item was repeated successively. The children were instructed to name the stimulus as quickly and correctly as possible, and the time taken to read each card was used as the outcome score. Errors made were not considered in the analyses. To compare the results with Waber et al., the mean of the letter- and number-naming scores was used in the analyses and in the NSD definition. A mean score one $S D$ slower than the normative mean served as the criterion for NSD.

The normative data on rapid naming were obtained from 605 children, aged 8-11 years (Ahonen, Tuovinen, \& Leppäsaari, 1999). The data were collected from four different schools in two cities and included children who had received special education services. To obtain a ratio between the size of the clinical group and control group similar to that in Waber et al,, a random sample of 119 children was selected from the normative group for analysis. The age distribution in the normative group used in this study $(N=119)$ followed that of the clinical sample. The remainder of the normative group not used in this study, $(N=486)$ was used for the purpose of defining naming speed deficit (NSD).

\section{Statistical Methods}

Statistical analysis was carried out with SPSS version 11.5. Receiver operating characteristic (ROC) analysis was applied and the area under the curve (AUC) obtained from the ROC analysis was taken as a measure of how accurately RAN performance predicted group membership. The AUC value ranges between .5 and 1.0, the former indicating a noninformative result and the latter a perfect discriminator. According to an arbitrary guideline an AUC value of .5-.7 indicates a poor or less accurate discriminator, .7-.9 a fair or moderately accurate discriminator, and .9-1.0 an excellent or highly accurate discriminator (Swets, 1988; Tape, n.d.).

In the ROC analysis, the mean $z$ score for number and letter naming was used as a dependent variable and group membership as a dichotomous state variable. The group comparisons consisted of LI children vs. controls, LI children with RD vs. controls, LI children without RD vs. controls, and LI children with RD vs. LI children without RD.

Logistic regression analysis was used to estimate optimal cutoff scores for RAN that would discriminate between the groups. The prevalences and distributions of the different diagnoses were conducted with cross-tabulations.

The distributions of all the rapid naming measures were skewed; hence they were normalized using natural logarithmic transformations. The effect of age on the rapid 
naming results was taken into account by using $z$ scores obtained by counting the norms for each age group $(8,9,10$, and 11 years) separately.

\section{RESULTS}

\section{Prevalence of Reading Disability and Naming Speed Deficit}

The prevalence of RD in the LI and NSD groups is presented in Table 2 and the prevalence of NSD in the different diagnostic groups in Table 3. The prevalence of RD defined by speed (RD-speed) was significantly greater than the prevalence of RD defined by accuracy (RD-accuracy) both in the LI group, $\chi^{2}(1)=19.03, p<.001$, and in the NSD group, $\chi^{2}(1)=8.58, p=.003$. Of the LI children, $78 \%$ had an RD of some kind. Of the RD sample $35 \%$ had RD-speed only, 11\% had RD-accuracy only, and 55\% had both RD diagnoses.

The prevalence of NSD was clearly greater in the RD groups than in the non-RD groups, $\chi^{2}(1)=28.64, p=.000$ for RD-speed, and $\chi^{2}(1)=11.49, p=.001$ for RDaccuracy. However, the proportion of children having NSD in the non-RD groups was relatively large compared to the control group, in which the prevalence of NSD was

Table 2 The Prevalence of RD in Learning Impaired and Naming Speed Deficit Groups in the Present Study and in Waber et al.

\begin{tabular}{|c|c|c|c|c|c|c|}
\hline \multirow[b]{2}{*}{ Group $\left(N^{\mathrm{a}}\right)$} & \multicolumn{3}{|c|}{$\%$ RD - speed $(N)$} & \multicolumn{3}{|c|}{$\%$ RD - accuracy $(N)$} \\
\hline & This study & Waber et al. & Difference & This study & Waber et al. & Difference \\
\hline LI (193/188) & $69.4(134)$ & $58.0(109)$ & $5.47 *$ & $50.8(98)$ & $32.0(60)$ & $14.02 * * *$ \\
\hline $\operatorname{NSD}(111 / 128)$ & $84.7(94)$ & $67.9(87)$ & $10.20 * *$ & $61.3(68)$ & $40.6(52)$ & $11.28 * * *$ \\
\hline No NSD (82/60) & $48.8(40)$ & $36.6(22)$ & $5.42 *$ & $36.6(30)$ & $15.0(9)$ & $11.32 * * *$ \\
\hline
\end{tabular}

Note. $\mathrm{RD}=$ Reading disability; LI = Learning impaired children; NSD = Learning impaired children with naming speed deficits. No NSD = LI Children without NSD. RD was diagnosed separately using either reading speed or reading accuracy as a criterion.

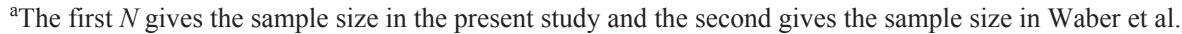

$* p<.05 . * * p<.01 . * * * p<.001$.

Table 3 The Prevalence of NSD in LI, RD, Non-RD, and Control Groups in the Present Study and in Waber et al.

\begin{tabular}{llclc}
\hline & \multicolumn{2}{c}{$\%$ NSD $(N)$} & & Difference \\
\cline { 2 - 3 } Group $\left(N^{\mathrm{a}}\right)$ & This study & Waber et al. & & $\chi^{2}(1)$ \\
\hline LI $(193 / 188)$ & $57.5(111)$ & $68(128)$ & $4.62 *$ \\
RD-speed $(134 / 109)$ & $70.1(94)$ & $80(87)$ & \\
RD-accuracy $(98 / 61)$ & $69.4(68)$ & $85(51)$ & $5.50 *$ \\
non-RD-speed (59/79) & $28.8(17)$ & $51(41)$ & \\
non-RD-accuracy (95/127) & $45.3(43)$ & $60(76)$ & $9.50 * *$ \\
\hline
\end{tabular}

Note. $\mathrm{NSD}=$ Naming speed deficits; $\mathrm{LI}=$ Learning impaired children; $\mathrm{RD}=$ Children with reading disabilities (defined by reading speed/accuracy); non-RD = Learning impaired children without RD (defined by reading speed/accuracy).

${ }^{\text {a The first }} N$ gives the sample size in the present study and the second the sample size in Waber et al.

$* p<.05 . * * p<.01 . * * * p<.001$. 
$16 \%, \chi^{2}(1)=4.04, p=.045$ compared to non-RD-speed, and $\chi^{2}(1)=22.03, p=.000$ compared to non-RD-accuracy.

In comparison with Waber et al. (2000), the prevalence of NSD in the present study was significantly smaller in all groups (see Table 3 ). This may be in great part due to the difference between naming times in control groups used. As shown in Table 1, there were no differences in the naming times of the alphanumeric stimuli between the LI samples. Instead, the children in Waber et al.'s control group were significantly faster namers in both subtasks than the controls used in the present study. The faster naming times in Waber et al.'s controls thus increased the distance between the LI and the control group and increased the prevalence of NSD.

The prevalence of RD in the LI and NSD groups on both RD definitions was significantly greater in the present study than in Waber et al. (2000; see Table 2). Despite the greater prevalence of NSD in the non-RD groups than control group in the present study, the tendency for NSD to be more common in the LI sample without RD was stronger in Waber et al. than in the present study, $\chi^{2}(1)=9.50, p<.01$ and $\chi^{2}(1)=9.64, p<.01$, non-RD-speed and non-RD-accuracy, respectively.

\section{ROC Analyses}

For the ROC analysis the mean $z$ score of the naming times in the RAN numbers and letters tests was entered as a continuous variable and a dichotomous group variable was used as a state variable. Table 4 displays the AUC statistics and $95 \%$ confidence intervals for every comparison obtained from the ROC analysis. The analysis showed that in all the comparisons, RAN time discriminated between the groups significantly better than chance.

Table 4 Area Under the Curve (AUC) and 95\% Confidence Intervals (CI) for Group Comparisons (Difference Between the Studies in AUC Statistics).

\begin{tabular}{|c|c|c|c|}
\hline \multirow[b]{2}{*}{ Group comparison } & \multicolumn{2}{|c|}{ AUC $(95 \% \mathrm{CI})$} & \multirow{2}{*}{$\frac{\text { Difference }}{z \text { score }}$} \\
\hline & This study & Waber et al. & \\
\hline LI vs. Control & $.79(.74, .84)$ & $.84(.79, .89)$ & 1.36 \\
\hline $\begin{array}{l}\text { RD vs. Control } \\
\text { Speed } \\
\text { Accuracy }\end{array}$ & $\begin{array}{l}.87(.83, .91)^{\mathrm{ab}} \\
.86(.81, .91)^{\mathrm{a}}\end{array}$ & $\begin{array}{l}.92(.88, .96) \\
.95(.91, .99)\end{array}$ & $\begin{array}{l}1.68 * \\
2.81 * *\end{array}$ \\
\hline $\begin{array}{l}\text { Non-RD vs. Control } \\
\text { Speed } \\
\text { Accuracy }\end{array}$ & $\begin{array}{l}.60(.51, .69) \\
.71(.64, .78)\end{array}$ & $\begin{array}{l}.72(.64, .80) \\
.79(.73, .85)\end{array}$ & $\begin{array}{l}1.95^{*} \\
1.68^{*}\end{array}$ \\
\hline $\begin{array}{l}\text { RD vs. Non-RD } \\
\text { Speed } \\
\text { Accuracy }\end{array}$ & $\begin{array}{l}.79(.71, .86)^{\mathrm{b}} \\
.67(.59, .74)\end{array}$ & $\begin{array}{l}.74(.67, .81) \\
.76(.68, .84)\end{array}$ & $\begin{array}{r}-0.98 \\
1.59\end{array}$ \\
\hline
\end{tabular}

Note. $\mathrm{LI}=$ Learning impaired children; $\mathrm{RD}=$ Learning impaired children with reading disabilities, $\mathrm{RD}$ defined by reading speed and accuracy; non- $\mathrm{RD}=$ Learning disabled children without RD, defined by speed and accuracy.

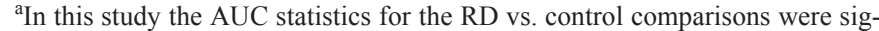
nificantly greater than the AUC statistics in the other comparisons, with one exception (see b). ${ }^{\mathrm{b}}$ In this comparison $Z=1.60 ; p=.55$.

$* p<.05$. $* * p<.01$. 
To compare RAN's ability to discriminate different groups from each other in this study and in Waber et al. (2000), a critical value $Z$ for the comparisons between AUC statistics was calculated. The formula used was $Z=\left(\mathrm{A}_{1}-\mathrm{A}_{2}\right) /\left(\mathrm{Se}_{1}{ }^{2}+\mathrm{Se}_{2}{ }^{2}\right)^{1 / 2}$, in which $\mathrm{A}_{1}$ and $\mathrm{A}_{2}$ mark the AUC statistics to be compared, and $\mathrm{Se}_{1}$ and $\mathrm{Se}_{2}$ the standard error for the corresponding AUC values (Hopley \& van Schalkwyk, 2001). The critical value, $Z$, followed the standardized normal distribution, and a $p$ value was obtained from the table in which the cumulative distribution functions were presented (StatSoft, Inc., n.d.).

The test described above was also used for comparing the AUC statistics within this study. The test showed that the AUCs were significantly greater in the RD-Control comparisons than other comparisons, except one (see Table 4), $Z$ values ranging from 1.90 to 4.97 , and $p$ values from .029 to .000 , respectively. The AUC for the RD-control comparison can be classified as good (Tape, n.d.). RAN also discriminated reliably between the whole LI group and control children, and between children with RD-speed and non-RD-speed (AUC between .7-.8 indicating fair or moderately accurate discrimination according to Swets, 1988 and Tape, n.d.). The AUCs for the non-RD versus control comparison were classified as fair and poor and thus could not be considered very reliable (Tape). The comparison between RD-accuracy and non-RD-accuracy also showed poor discrimination.

The AUC values were systematically lower in the present study than in Waber et al. (2000). Both the RD vs. control comparisons and non-RD vs. control comparisons obtained a significantly lower AUC value than Waber et al. (see Table 4), while no difference between the studies in the LI-control and RD-non-RD comparisons were found. The controls in Waber et al. were relatively fast namers as compared to controls in this study. This might explain the relatively large AUC values in LI-control comparisons of Waber et al., and the difference between studies in these comparisons.

Waber et al. (2000) found that (a) RAN discriminated LI children from controls (AUC .84), especially if they had RD (AUCs .92 and .95 for controls vs. RD-speed and RD-accuracy, respectively), and (b) also, but to a lesser extent, discriminated non-RD children from controls (AUCs .72 and .79 when RD was defined by speed and accuracy, respectively), and RD from non-RD children (AUCs .74 for RD-speed and .76 for RDaccuracy). The results of this study were basically the same, but whereas Waber et al. concluded that RAN had some utility in distinguishing between RD children and other LI children but showed greater reliability in discriminating between LI children and controls, the results of the present study showed that when RD was defined by speed, the discriminating power of RAN was about the same size (AUC .79) in both the LI vs. control and RD-speed vs. non-RD-speed analyses. In this study RAN also discriminated better between RD and non-RD (AUC .79) than between non-RD and controls (AUC .60), when $\mathrm{RD}$ was defined by speed, while in Waber et al. these statistics were about the same size.

\section{Cutoff Scores}

Logistic regression was used to estimate which cutoff score best discriminated between the groups. This was done by assigning a dichotomous cutoff variable for each cutoff score used in the analysis. A separate logistic regression was then computed for each cutoff, the group variable being the dependent variable and the cutoff variable the categorical predictor variable. The analysis yielded correctly and incorrectly classified cases.

Following Waber et al. (2000), the best cutoff score was the one that produced the greatest percentage of correct classifications (see Table 5). For most of the comparisons, 
Table 5 The Percentage of Correct Classifications on Different RAN Cutoff Scores (False Positives / False Negatives on the Best Cutoff Points).

\begin{tabular}{|c|c|c|c|c|c|}
\hline Group Comparison & $0.5 S D$ & $1.0 S D$ & $1.5 S D$ & $2.0 S D$ & $2.5 S D$ \\
\hline LI vs. Control & $.71(.19 / .39)$ & $.68(.15 / .45)$ & .63 & .57 & .50 \\
\hline \multicolumn{6}{|l|}{ RD vs. Control } \\
\hline Speed & $.78(.23 / .21)$ & $.77(.17 / .29)$ & .73 & .68 & .60 \\
\hline Accuracy & $.76(.30 / .18)$ & $.77(.22 / .23)$ & .76 & .71 & .68 \\
\hline \multicolumn{6}{|l|}{ RD vs. Non-RD } \\
\hline Speed & $.75(.19 / .41)$ & $.70(.15 / .49)$ & .64 & .56 & .47 \\
\hline Accuracy & $.60(.42 / .34)$ & $.51(.39 / .63)$ & .61 & .58 & .60 \\
\hline
\end{tabular}

Note. $\mathrm{LI}=$ Learning impaired children; $\mathrm{RD}=$ Learning impaired children with reading disabilities, $\mathrm{RD}$ defined by reading speed and accuracy; non-RD = Learning disabled children without $\mathrm{RD}$, defined by speed and accuracy.

$-0.5 S D$ was the best cutoff; although the difference between $-0.5 S D$ and $-1.0 S D$ was small. The highest percentage of correct classifications was $78 \%$ for the RD (speed) vs. non-RD comparison, with $23 \%$ false positives and $21 \%$ false negatives. For the other comparisons, at the point where the percentage of correct classifications was at its highest, the proportion of false positives ranged from $19 \%$ to $46 \%$ and false negatives from $21 \%$ to $41 \%$.

\section{Comorbidity of Diagnoses and the Prevalence of NSD in Different Clinical Groups}

As in Waber et al. (2000), a description of the clinical profiles of the LI children was provided. The distribution of the $\mathrm{RD}, \mathrm{AD}$, and $\mathrm{MD}$ groups, and the different combinations of these, are displayed in Table 6, with information on the prevalence of NSD in each group. The groups identified were all mutually exclusive. There were some gaps in the clinical data with respect to the diagnoses of MD and AD. The most likely reason for a missing diagnosis was that children referred for the evaluation of learning problems did not exhibit any signs of the deficit in question and therefore were not examined for them. In other words, a missing diagnosis would in high probability mean no problems in the skills not evaluated. On this assumption, children with missing diagnostic information were coded as not having the disorder in question. The prevalence of NSD in the different diagnostic groups did not change markedly with the replacement of missing information (see Table 6).

The prevalence of NSD in the clinical groups was somewhat different in the present sample compared to that in Waber et al. (2000), as can be seen in Table 6. The prevalence of NSD in the present sample was $26 \%-30 \%$ in the LI groups without RD and $59 \%-89 \%$ in the LI groups with RD of some kind. Thus, unlike in the sample of Waber et al. in which the prevalence of NDS increased with the comorbidity of learning impairments, in the present sample the prevalence of NSD increased with diagnosed RD.

Another difference between Waber et al. (2000) and the present study was in the composition of the groups. In the present sample the prevalence of learning disabilities was rather high (RD 78\%, AD 60\%, and MD 45\%) compared to the sample in Waber et al. (RD 32\%, AD 13\%, and MD 43\%). Accordingly, the comorbidity of different diagnoses was fairly high in the present clinical sample: $64 \%$ of the sample had more than one diagnosis and only $4 \%$ of the sample had none. In the LI sample in Waber et al., comorbidity was far more uncommon: only $23 \%$ of the sample had more than one diagnosis and $37 \%$ 
Table 6 Percentage of Naming Speed Deficits (NSD) in Groups with Different Combinations of Reading, Mathematics, or Attention Deficits.

\begin{tabular}{|c|c|c|c|c|}
\hline \multirow[b]{2}{*}{ Deficits } & \multicolumn{2}{|c|}{$\%$ with NSD } & \multicolumn{2}{|c|}{$N$} \\
\hline & This study & Waber et al. & This study & Waber et al. \\
\hline $\mathrm{RD}, \mathrm{MD}, \mathrm{AD}$ & $64(64)$ & 100 & $42(42)$ & 3 \\
\hline $\mathrm{RD}, \mathrm{AD}$ & $59(54)$ & 100 & $44(26)$ & 2 \\
\hline $\mathrm{MD}, \mathrm{AD}$ & $30(30)$ & 100 & $10(10)$ & 5 \\
\hline $\mathrm{RD}, \mathrm{MD}$ & $89(91)$ & 94 & $27(22)$ & 33 \\
\hline $\mathrm{RD}$ & $60(54)$ & 82 & $37(24)$ & 23 \\
\hline MD & $29(29)$ & 82 & $7(7)$ & 39 \\
\hline $\mathrm{AD}$ & $26(17)$ & 64 & $19(12)$ & 14 \\
\hline None & $29(0)$ & 43 & $7(4)$ & 69 \\
\hline
\end{tabular}

Note $. \mathrm{RD}=$ Reading disability $\mathrm{MD}=$ Mathematic disability; $\mathrm{AD}=$ Attention deficit. $\mathrm{RD}$ is defined by speed and accuracy of text reading. Information before replacement of missing values is given in parentheses.

of the sample had no diagnoses. The difference between the studies in the prevalence of comorbidity was significant, $\chi^{2}(1)=64.72, p<.001$.

\section{DISCUSSION}

The aim of this study was to extend the study by Waber et al. (2000) on rapid naming and to test the efficacy of RAN in discriminating between various clinical and control groups. The results of this study concurred with those obtained by Waber et al. and previous studies in that RAN differentiated RD from controls (e.g., Denckla \& Rudel, 1976; O’Malley et al., 2002; Wolf, 1986) and that the connection between RAN and RD was found to be stronger than the connection between RAN and learning problems in general. The results of the non-RD vs. control and RD vs. non-RD comparisons were parallel in that all the discriminations were statistically significant but not as robust as in the RD vs. control comparisons. Over and above the minor differences between the studies, the present study seemed to differ from Waber et al. in one major respect. While Waber et al. concluded that RAN was an excellent diagnostic indicator of learning problems that may include, but are not limited to, reading (p. 258), the results of the present study point to a more specific connection between RD and RAN. There are three main reasons for this.

First, in the study by Waber et al. (2000) the likelihood of NSD increased with the number of diagnoses but was not dependent on the type of diagnosis. Children with more than one diagnosis had a nearly $100 \%$ likelihood of having NSD, which was interpreted to mean that prolonged naming speed was an indicator of learning problems in general, independent of any specific diagnosis. In the present study, the prevalence of NSD did not increase with the number of diagnoses. Instead, the prevalence of NSD was significantly greater in the groups with RD (59\%-89\%) than in the LI groups without RD $(26 \%-30 \%)$. It should be noted that this comparison was made against a non-RD group in which there were no problems in either reading accuracy or reading speed.

Second, the ROC analyses revealed that RAN differentiated between the RD groups significantly better than any of the other groups from the control group. According to Tape's (n.d.) classification for AUC statistics, RAN was a good discriminator only for the $\mathrm{RD}$ vs. control comparisons, showing fair or poor discriminating power in all the other 
comparisons. RAN was not especially good in discriminating between the non-RD-LI children and control children; RAN's discriminating power being at best .71, which means barely fair in Tape's classification. In addition, RAN reliably differentiated the RD-speed group from the non-RD-speed group.

Third, although the prevalence of NSD was greater in the non-RD groups than in the control group, the trend was significantly stronger in Waber et al. (2000) than in the present study. The present results are in line with those of previous studies. Previous research has shown that RAN is one of the strongest and most persistent variables connected to reading disabilities (e.g., De Jong \& van der Leij, 2003; Korhonen, 1995; Wimmer, 1993). According to Wolf and Bowers (1999), the processes involved in reading and RAN are highly comparable, which explains the strong connection between these two tasks. In light of these studies the result that RAN was strongly connected to RD was no less than expected.

A more interesting result was that the connection between RAN and the other learning disabilities failed to be replicated. Beginning with attention problems, the results of this study are in line with those of previous studies that have not found a consistent connection between RAN and ADHD (e.g., Felton et al., 1987; Närhi \& Ahonen, 1995; Semrud-Clikeman, Guy, Griffin, \& Hynd, 2000) and have claimed that RAN is more strongly connected to RD than ADHD (e.g., Felton \& Wood, 1989; Raberger \& Wimmer, 2003). However, the link between RAN and attention may be mediated by the subtype of attention problems; in which case the inattentive type of ADHD would be expected to be linked to RAN while the hyperactive type would not (Hynd et al., 1991; Thomson et al., 2005). In the study by Waber et al. (2000), only children with the inattentive type of ADHD were studied whereas the present study included children with a range of attention problems. This difference could explain the stronger connection between RAN and attention problems in Waber et al. than in the present sample; however, this hypothesis remains to be confirmed in further studies.

The connection between RAN and MD also warrants more profound investigation. In the MD groups the prevalence of NSD varied between $29 \%$ and $89 \%$ and hence the result does not reveal very much about the connection between RAN and MD. However, the fact that the highest prevalence of NSD was found in the MD+RD group might lend support to the previous suggestion that NSD, or "retrieval deficit" is one of the contributors to the comorbidity of MD and RD (Geary, 1993; Geary, Hamson, \& Hoard, 2000); whereas difficulties in number naming were not evident in the children with MD alone (Geary et al., 2000). In light of the studies by Koponen (Koponen et al., 2006; Koponen et al., 2007) it is arguable that had the measure used in the identification of MD been based on calculating speed rather than accuracy, the connection between RAN and MD might have been stronger.

Taken together, the results of this study underpin the results of previous studies in which the connection between RAN and RD has been stronger than the connection between RAN and learning problems in general (Denckla \& Rudel, 1976; Denckla, Rudel, $\&$ Broman, 1981). However, because of the comorbidity commonly found between different kinds of learning disabilities (Adler, Barkley, Wilens, \& Gingsberg, 2006; Biederman et al., 2004; Knopik, Alarcón, \& DeFries, 1997), the results of both this study and that of Waber et al. (2000) strongly indicate the need to take comorbid LIs into account when studying RAN and RD.

\section{Methodological and Statistical Considerations}

Because clinical samples often differ greatly in their composition, it is important to look more closely at the samples used when comparing studies. The differences between 
the present study and that of Waber et al. (2000) are unlikely to be due to subjects' socioeconomic status, age, or the selection criteria used since they were highly comparable. However, some of the differences between the two studies may in part have been caused by statistical and sample-related differences. These will be discussed briefly.

First, the prevalence of NSD was significantly greater in Waber et al. (2000) than in the present study. As explicated before, this may be in great part due to the difference between naming times in control groups while the naming times in LI groups were about the same size between studies (Table 1). In addition to the prevalence of NSD this difference between studies also has implications on the AUC statistics so that the LI vs. control comparisons reach greater values in Waber et al. than in the present study. This may in part explain the difference between studies in this matter. What made the Finnish control children slower namers than the U.S. children is not easy to say; while both of the normative groups were appropriate. However, the discrepancies between the studies on these measures may have no theoretical importance relative to the primary question, since the relationships between the groups remain the same.

The second difference between the studies concerns the composition of the clinical groups with their different combinations of learning disabilities. The comorbidity of different diagnoses was far more common in the present study than in Waber et al. (2000), which may partly be a result of the inclusion criteria used, especially for AD. Waber et al. excluded children with hyperactivity, and no such exclusion criterion was applied in the present study. This naturally increased the prevalence of attention problems in the present sample and thus comorbidity. There was also a difference between studies in the prevalence of reading disabilities; the present sample included more children with RD. This was not likely to be due to the reading tasks used because of the high correlation between text reading and word reading fluency in the second grade both in children whose languages have transparent orthography (.89 in Greek) and also in English (.91; Georgiou, Parrila, \& Papadopoulos, 2008). While the inclusion criterion for RD was stricter in the present study (1.5 SD from the normative mean) than in the study by Waber et al. (1.0 SD from the normative mean or a reading level $-1.5 S D$ from expected according to IQ), and hence should not lead to a higher prevalence of $\mathrm{RD}$, the differences between the studies are more likely to be based on differences in the referral procedures of the clinic, as explicated below.

Third, there was difference between the studies in intelligence; the present sample being lower in IQ. There was a minor difference between the studies in the selection criterion for the LI samples, as the present sample included some children with Full Scale IQ below 80, which was an exclusion criterion in Waber et al. (2000). However, when these children were excluded, the difference between the studies remained. One reason for the lower IQ and also for the higher comorbidity of learning disabilities in our sample may be the selection of children to the clinic for the evaluation of learning disabilities. The clinic serves a relatively large area covering several municipalities and children were referred to the clinic if the local services for assessment and support had not been sufficient. This could explain why comorbid disorders, which are often considered more problematic, were more frequent in our sample. While some of the LI groups (math only and no LI groups this study and almost all of the comorbid groups in Waber et al.) were very small, the outcomes within these should be considered cautiously.

Finally, there was a problem in the definition of the RD subgroups and their non-RD controls in Waber et al. (2000). While the RD subgroups were defined by problems of either speed or accuracy, the non-RD-speed group might include children with reading accuracy problems and the non-RD-accuracy group children with reading speed problems. 
For this reason, the comparisons between the non-RD and $\mathrm{RD}$ or control groups are difficult to interpret. This problem should not affect the difference between the studies, but it might explain why the discriminatory power of RAN was at its lowest in these particular comparisons.

\section{CONCLUSION}

To conclude, the results of the present study indicated that in a clinical sample, RAN seemed to be more connected to RD than to other learning disabilities. This conclusion diverged from that of Waber et al. (2000), in which RAN was considered an excellent tool for detecting learning disabilities in general but not specifically for detecting reading disabilities.

The results also indicate that RAN may have different connections with different learning disabilities; this would mean that the results obtained for a specific learning impairment may not be generalizable to all learning impairments. However, further research is needed on this issue, especially on whether problems in RAN performance are similar among different diagnostic groups and whether such groups differ in the background skills needed for the successful performance of a RAN task. As Waber et al. (2000) mentioned, different diagnostic groups may demonstrate naming speed deficits for different reasons, and thus there is a need to explore whether the cause of slow naming lies in linguistic skills, nonlinguistic processing skills, or something else. In addition, there is an obvious need for more studies in this area to confirm the present results, as the criteria used to identify LIs and clinical samples vary widely and may be biased in several ways.

Original manuscript received February 25, 2008 Revised manuscript accepted October 3, 2008 First published online March 23, 2009

\section{REFERENCES}

Achenbach, T. M. (1991a). Manual for the Child Behavior Checklist/4-18 and 1991 profile. Burlington, VT: Department of Psychiatry, University of Vermont.

Achenbach, T. M. (1991b). Manual for the teacher's report form and 1991 profile. Burlington, VT: Department of Psychiatry, University of Vermont.

Adler, L. A., Barkley, R. A., Wilens, T. E., \& Gingsberg, D. L. (2006). Differential diagnosis of attention-deficit/hyperactivity disorder and comorbid conditions. Primary Psychiatry, 13(5), 1-14.

Ahonen, T., Tuovinen, S. \& Leppäsaari, T. (1999). Nopean sarjallisen nimeämisen testi [The test of rapid serial naming]. Jyväskylä, Finland: Niilo Mäki Instituutti \& Haukkarannan koulu.

Badian, N. A. (1993). Phonemic awareness, naming, visual symbol processing, and reading. Reading and Writing: An Interdisciplinary Journal, 5, 87-100.

Berninger, V. W., Abbott, R. D., Thomson, J. B., \& Raskind, W. H. (2001). Language phenotype for reading and writing disability: A family approach. Scientific Studies of Reading, 5(1), 59-106.

Biederman, J., Monuteaux, M. C., Doyle, A. E., Seidman, L. J., Wilens, T. E., Ferrero, F., et al. (2004). Impact of executive function deficits and attention-deficit/hyperactivity disorder (ADHD) on academic outcomes in children. Journal of Consulting and Clinical Psychology, 72(5), 757-766.

Bowers, P. G., Golden, J., Kennedy, A., \& Young, A. (1994). Limits upon orthographic knowledge due to processes indexed by naming speed. In V. W. Berninger (Ed.), The varieties of orthographic knowledge, 1: Theoretical and developmental issues. Neuropsychology and cognition (pp. 173-218). Dordrecht, The Netherlands: Kluwer. 
Bowers, P.G., \& Newby-Clark, E. (2002) The role of naming speed within a model of reading acquisition. Reading and Writing 15 (1-2), 109-126.

Bowers, P. G., Steffy, R., \& Tate, E. (1988). Comparison of the effects of IQ control methods on memory and naming speed predictors of reading disability. Reading Research Quarterly, 23, 304-309.

Carver, R. P. (1991). Using letter-naming speed to diagnose reading disability. Remedial and Special Education, 12(5), 33-43.

Davis, J. M., \& Spring, C. (1990). The Digit Naming Speed Test: Its power and incremental validity in identifying children with specific reading disabilities. Psychology in the Schools, 27, 15-22.

De Jong, P. F., \& Van der Leij, A. (1999). Specific contributions of phonological abilities to early reading acquisition: Results from a Dutch latent variable longitudinal study. Journal of Educational Psychology, 91(3), 450-476.

De Jong, P. F. \& Van der Leij, A. (2003). Developmental changes in the manifestation of a phonological deficit in dyslexic children learning to read a regular orthography. Journal of Educational Psychology, 95(1), 22-40.

Denckla, M. B., \& Cutting, L. E. (1999). History and significance of rapid automatized naming. Annals of Dyslexia, 49, 29-42.

Denckla, M. B., \& Rudel, R. G. (1976). Rapid automatised naming (R.A.N.): Dyslexia differentiated from other learning disabilities. Neuropsychologia, 14, 471-479.

Denckla, M. B., Rudel, R. G. \& Broman, M. (1981). Tests that discriminate between dyslexic and other learning-disabled boys. Brain and Language, 13(1), 118-129.

Felton, R. H., \& Wood, F. B. (1989). Cognitive deficits in reading disability and attention deficit disorder. Journal of Learning Disabilities, 22, 3-13.

Felton, R. H., Wood, F. B., Brown, I. S., Campbell, S. K., \& Harter, M. R. (1987). Separate verbal memory and naming deficits in attention deficit disorder and reading disability. Brain and Language, 31, 171-184.

Geary, D. C. (1993). Mathematical disabilities: Cognitive, neuropsychological, and genetic components. Psychological Bulletin, 114, 345-362.

Geary, D. C., Hamson, C., \& Hoard, O. (2000). Numerical and arithmetical cognition: A longitudinal study of process and concept deficits in children with learning disability. Journal of Experimental Child Psychology, 77, 236-263.

Georgiou, G. K., Parrila, R., \& Papadopoulos, T. C. (2008). Predictors of word decoding and reading fluency across languages varying in orthographic consistency. Manuscript submitted for publication.

Hammill, D. D. (2004). What we know about correlates of reading. Exceptional Children, 70(4), 453-468.

Hammill, D. D., Mather, N., Allen, E. A., \& Roberts, R. (2002). Using semantics, grammar, phonology, and rapid naming tasks to predict word identification. Journal of Learning Disabilities, 35 , 121-136.

Ho, C. S.-H., Chan, D. W.-O., Leung, P. W. L., Lee, S.-H., \& Tsang S.-M. (2005). Readingrelated cognitive deficits in developmental dyslexia, attention-deficit/disorder, and developmental coordination disorder among Chinese children. Reading Research Quarterly, 40, 318-337.

Hopley, L. \& van Schalkwyk, J. (2001, September 21). The Magnificent ROC. Retrieved November 18, 2008, from http://www.anaesthetist.com/mnm/stats/roc/Findex.htm

Hynd, G., Lorys, A., Semrud-Clikeman, M., Nieves, N., Huettner, M., \& Lahey, B. (1991). Attention deficit disorder without hyperactivity: A distinct behavioral and neurocognitive syndrome. Journal of Child Neurology, 6, 37-43.

Kail, R., Hall, L. K., \& Caskey B. J. (1999). Processing speed, exposure to print, and naming speed. Applied Psycholinguistics 20, 303-314.

Kaufman, A. S. (1983). Kaufman Assessment Battery for Children. Circle Pines, MN: American Guidance Service. 
Knopik, V. S., Alarcón, M., \& DeFries, J. C. (1997). Comorbidity of mathematics and reading deficits: Evidence for a genetic etiology. Behavior Genetics, 27(5), 447-453.

Koponen, T., Aunola, K., Ahonen, T., \& Nurmi, J.-E. (2007). Cognitive predictors of single-digit and procedural calculation and their covariation with reading skill. Journal of Experimental Child Psychology, 97, 220-241.

Koponen, T., Mononen, R., Räsänen, P., \& Ahonen, T. (2006). Basic numeracy in children with specific language impairment: Heterogeneity and connections to language. Journal of Speech, Language, and Hearing Research, 46, 1-16.

Korhonen, T. (1995). The persistence of rapid naming problems in children with reading disabilities: A nine year follow-up. Journal of Learning Disabilities, 28, 232-239.

Manis, F. R., Doi, L. M., \& Bhadha, B. (2000). Naming speed, phonological awareness, and ortographic knowledge in second graders. Journal of Learning Disabilities, 33(4), 325-333, 374 .

Meyer, M. S., Wood, F. B., Hart, L. A., \& Felton, R. H. (1998). Selective predictive value of rapid automatized naming in poor readers. Journal of Learning Disabilities, 31(2), 106-117.

Närhi, V., \& Ahonen, T. (1995). Reading disability with or without attention deficit hyperactivity disorder: Do attentional problems make a difference? Developmental Neuropsychology, 11(3), 337-349.

Närhi, V., Ahonen, T., Aro, M., Leppäsaari, T., Korhonen, T. T., Tolvanen, A., \& Lyytinen, H. (2005). Rapid serial naming: Relations between different stimuli and neuropsychological factors. Brain and Language, 92, 45-57.

Närhi, V., Laaksonen, S., Hietala, R., Ahonen, T., \& Lyytinen, H. (2001). Computerizing the clinician. Treating missing data in a clinical neuropsychological dataset - Data imputation. The Clinical Neuropsychologist, 15, 380-392.

Niilo Mäki Institute. (2004). Neuropsychological and achievement tests: Local normative data for Niilo Mäki Institute test battery. Jyväskylä, Finland: Author.

O’Malley, K. J., Francis, D. J., Foorman, B. R., Fletcher, J. M., \& Swank, P. R. (2002). Growth in precursor and reading-related skills: Do low-achieving and IQ-discrepant readers develop differently? Learning Disabilities Research \& Practice, 17, 19-34.

Puolakanaho, A., Ahonen, T., Aro, M., Eklund, K., Leppänen, P. H. T., Poikkeus, A.-M., et al. (2007). Very early phonological and language skills: Estimating individual risk of reading disability. Journal of Child Psychology and Psychiatry, 48, 923-931.

Raberger, T., \& Wimmer, H. (2003). On the automaticity/cerebellar deficit hypothesis of dyslexia: Balancing and continuous rapid naming in dyslexic and ADHD children. Neuropsychologia, 41, 1493-1497.

Räsänen, P. (2004). RMAT - Laskutaidon testi 9-12 -vuotiaille. [RMAT arithmetic test for grade levels 2 to 6]. Jyväskylä, Finland: Niilo Mäki Instituutti.

Reiter, B. A. (2001). Reading disabilities related to word recognition: Underlying deficits and diagnostic approaches. Canadian Journal of School Psychology, 17, 65-84.

Scarborough, H. (1998). Predicting the future achievement of second graders with reading disabilities: Contribution of phonemic awareness, verbal memory, rapid naming, and IQ. Annals of Dyslexia, 48, 115-136.

Semrud-Clikeman, M., Guy, K., Griffin, J. D., \& Hynd, G. W. (2000). Rapid naming deficits in children and adolescents with reading disabilities and attention deficit hyperactivity disorder. Brain \& Language, 74, 70-83.

Spring, C., \& Davis, J. (1988). Relations of digit naming speed with three components of reading. Applied Psycholinguistics, 9, 315-334.

Sprugevica, I., \& Høien, T. (2004). Relations between enabling skills and reading comprehension: A follow-up study of Latvian students from first to second grade. Scandinavian Journal of Psychology, 45, 115-122.

StatSoft, Inc. (n.d.). Distribution Tables (Z Table). Retrieved December 28, 2007, from http:// www.statsoft.com/textbook/sttable.html\#z 
Swets, J. A. (1988). Measuring the accuracy of diagnostic systems. Science, 240, 1285-1293.

Tape, T. G. (n.d.). Interpreting diagnostic tests. Retrieved December 28, 2007, from http://gim. unmc.edu/dxtests/ROC3.htm

Temple, C. M., \& Sherwood, S. (2002). Representation and retrieval of arithmetic facts: Developmental difficulties. Quarterly Journal of Experimental Psychology, 55A, 733-752.

Thomson, J. B., Chenault, B., Abbot, R. D., Raskind, W. H., Richards, T., Aylward, E., et al. (2005). Converging evidence for attentional influences on the orthographic word form in child dyslexics. Journal of Neurolinguistics, 18, 93-126.

Van der Sluis, S., De Jong, P. F., \& van der Leij, A. (2004). Inhibition and shifting in children with learning deficits in arithmetic and reading. Journal of Experimental Child Psychology, 87, 239-266.

Vukovic, R. K., \& Siegel, L. S. (2006). The double-deficit hypothesis: A comprehensive analysis of the evidence. Journal of Learning Disabilities, 39, 25-47.

Vukovic, R. K., Wilson, A. M., \& Nash, K. K. (2004). Naming speed deficits in adults with reading disabilities: A test of the double-deficit hypothesis. Journal of Learning Disabilities, 37(5), 440-450.

Waber, D. P., Wolff, P. H., Forbes, P. W., \& Weiler, M. D. (2000). Rapid automatized naming in children referred for evaluation of heterogeneous learning problems: How specific are naming speed deficits to reading disability? Child Neuropsychology, 6, 251-261.

Wechsler, D. (1974). Wechsler Intelligence Scale for Children (Rev. ed.). New York: Psychological Corporation.

Wechsler, D. (1991). Wechsler Intelligence Scale for Children (3rd. ed.). New York: Psychological Corporation.

Wimmer, H. (1993). Characteristics of developmental dyslexia in a regular writing system. Applied Psycholinguistics, 14, 1-33.

Wolf, M. (1986). Rapid alternating stimulus naming in the developmental dyslexias. Brain and Language, 27, 360-379.

Wolf, M., \& Bowers, P. G. (1999). The double-deficit hypothesis for the developmental dyslexias. Journal of Educational Psychology, 91, 415-438.

Wolf, M., Bowers, P. G., \& Biddle, K. (2000). Naming-speed processes, timing, and reading: A conceptual review. Journal of Learning Disabilities, 33, 387-407.

Young, A., \& Bowers, P. G. (1995). Individual difference and text difficulty determinants of reading fluency and expressiveness. Journal of Experimental Child Psychology, 60, 428-454. 


\section{II}

\section{DOUBLE-DEFICIT HYPOTHESIS IN A CLINICAL SAMPLE: EXTENSION BEYOND READING.}

by

Riikka Heikkilä, Minna Torppa, Mikko Aro, Vesa Närhi, \& Timo Ahonen, 2015

Journal of Learning Disabilities. Advance online publication. doi:10.1177/0022219415572895

Reproduced with kind permission by Sage. 


\title{
The double-deficit hypothesis in a clinical sample: extension beyond reading.
}

\author{
Riikka Heikkiläa,b, Minna Torppa ${ }^{\mathrm{b}}$, Mikko Aro ${ }^{\mathrm{b}}$, Vesa Närhiª,c, and Timo \\ Ahonen ${ }^{b}$
}

\author{
a Niilo Mäki Institute \\ b University of Jyväskylä \\ c University of Eastern Finland
}

This study explored the double-deficit hypothesis (DDH) in a transparent orthography (Finnish), and extended the view from reading disabilities to comorbidity of learningrelated problems in math and attention. Children referred for evaluation of learning disabilities in second through sixth grade $(N=205)$ were divided into four groups based on rapid automatized naming (RAN) and phonological awareness (PA) according to the DDH: the double-deficit group, the naming speed deficit only group, the phonological deficit only group, and the no deficit group. The results supported the DDH in that the prevalence and severity of reading disability were greatest in the double-deficit group. Despite the greater prevalence of reading disabilities in single-deficit groups compared to the no deficit group, the means of reading measures in the single-deficit groups were similar to those of the no deficit group. The PA single-deficit group was poorer in spelling than the no deficit group and single naming deficit group. Deficits in RAN or $P A$ were primarily linked to reading disabilities, but not with math or attention problems. The results supported the double-deficit hypothesis partially and indicate that deficits in RAN and PA are specific to reading disabilities. 


\section{INTRODUCTION}

\subsection{The double-deficit hypothesis}

The double-deficit hypothesis (DDH; Wolf \& Bowers, 1999, 2000) was presented as an alternative for the phonological deficit hypothesis that has long been the predominant theory to explain the background of reading disabilities (RD; e.g., Stanovich \& Siegel, 1994; Vellutino, Fletcher, Snowling, \& Scanlon, 2004). DDH states that there are two partially independent core deficits behind RDs: deficits in phonological awareness (PA) and rapid automatized naming (RAN). Combinations of these deficits lead to three subgroups: double deficit (DD, deficits in RAN and PA), phonological deficit (PD) only, and naming speed deficit (NSD) only. It is assumed that the negative effects of PD and NSD are additive, and thus, RDs are more severe in the DD group than in single-deficit groups (Wolf \& Bowers, 1999). An additional linked hypothesis is that PA and RAN are associated with different aspects of literacy: PA has been primarily connected with reading and spelling accuracy, and RAN has been especially linked with reading fluency and rate (Compton, DeFries, \& Olson, 2001; Cornwall, 1992; Furnes \& Samuelsson, 2011; Kairaluoma, Torppa, Westerholm, Ahonen, \& Aro, 2013; Moll, Ramus, et al., 2014; Papadopoulos, Georgiou, \& Kendeou, 2009; Pennington, Cardoso-Martins, Green, \& Lefly, 2001; Schatschneider, Carlson, Francis, Foorman, \& Fletcher, 2002; Sunseth \& Bowers, 2002; Torppa, Georgiou, Salmi, Eklund \& Lyytinen, 2012; Vaessen, Gerretsen, \& Blomert, 2009; Vaessen et al., 2010; Wimmer, Mayringer, \& Landerl, 2000, however, see Moll, Ramus, et al., 2014, and Ziegler et al., 2010 for contradictory findings on RAN's role concerning Finnish samples).

The double-deficit hypothesis serves as a plausible model for explaining reading problems, especially in more transparent orthographies. Due to the fast development of reading accuracy (Seymour, Aro, \& Erskine, 2003), PA's role in predicting reading skills seems to be limited to the first school grades in these orthographies (Aarnoutse, van Leeuwe, \& Verhoeven, 2005; Papadopoulos et al., 
2009;Torppa et al., 2012; Wimmer et al., 2000) whereas RAN seems to be a more robust predictor of reading, particularly rate and fluency after early grades than PA (see e.g. Kirby, Georgiou, Martinussen, \& Parrila, 2010; Norton \& Wolf, 2012; Wolf, Bowers, \& Biddle, 2000, for reviews). That said, DDH has received support across orthographies in studies of school-aged children in unselected samples as well as among poor readers (see Georgiou \& Parrila, 2013; Kirby et al., 2010; Norton \& Wolf, 2012, and Wolf et al., 2000 for reviews, and Cronin, 2013; Norton et al., 2014; Steacy, Kirby, Parrila, \& Compton, 2014; Torppa et al., 2012; Torppa et al., 2013, for latest results). Some studies, however, have not found support for the independent role of RAN in explaining RDs (for a review, see Vukovic \& Siegel, 2006). One reason for the lack of a RAN-RD link may be the use of RD definitions that are based solely on accuracy leaving the variation between RAN and reading fluency uncontrolled. There are also contradictory findings on the role of single-deficit subgroups based on DDH: even though a group with double-deficit has often been the poorest in most literacy skills, not all studies have found significant differences between single-deficit groups in reading skills (e.g. Manis, Doi, Bhadha, 2000; Cronin, 2013; Norton et al., 2014, see also Wolf \& Bowers, 1999 for review).

\subsection{DDH and comorbid problems with RDs: math disabilities and attention deficit}

In addition to RDs, deficits in phonological processing and RAN may influence comorbid problems such as math disabilities (MDs) and attention deficit (AD). RD is often comorbid with MD and AD (Czamara et al., 2013; DuPaul, Gormley, \& Laracy, 2013; Landerl \& Moll, 2010; see Boada, Willcutt, \& Pennington, 2012; Germanò, Gagliano, \& Curatolo, 2010; Sexton, Gelhorn, Bell, \& Classi, 2012, and Willcutt, Pennington, et al., 2010 for reviews). Most studies, however, have studied RDs, MDs, and AD separately, or subjects with comorbid learning problems have been excluded from analyses. Even though the etiology of these disabilities seem to partly overlap (Hart, Petrill, Thompson, \& Plomin, 2010; Kovas et al., 2007; Willcutt, Pennington, et al., 2010), consensus on the cognitive or behavioral factors associated with the comorbidity is lacking (see e.g. Miranda, Presentación, Siegenthaler, Colomer, \& Pinto, 2011, for a discussion on the comorbidity between RD and AD). In addition, it has been suggested that the comorbidity of learning disabilities and attention deficit may be related with more severe neuropsychological deficits than single disabilities (Boada et al., 2012; Miranda et al., 2011). Therefore, attempts to discover the specific underlying deficits in each disability as well as the common factors associated with the comorbidity are important in detecting and diagnosing these disabilities and preventing the secondary causes of comorbid disabilities. Essential from the perspective of double-deficit hypothesis is the possibility that 
deficits in phonological processing or RAN are linked not only with RDs but also with other challenges in learning, increasing the comorbidity of learning disabilities and AD. Although naming speed (Denckla \& Rudel, 1976; Heikkilä, Närhi, Aro, \& Ahonen, 2009; Willcutt, Betjemann, et al., 2010) and phonological deficits (Fletcher, 2005; Landerl, Fussenger, Moll, \& Willburger, 2009) seem to be most strongly connected with RDs, links with MDs and AD have been found (see below).

Evidence for the effects of RAN and phonological skills on math is mixed. Some studies have shown a unique connection between RAN and math skills (Ackerman, Holloway, Youngdahl, \& Dykman, 2001; Koponen, Aunola, Ahonen, \& Nurmi, 2007; Koponen, Salmi, Eklund, \& Aro, 2013; Murphy, Mazzocco, Hanich, \& Early, 2007; van Bergen, de Jong, Maassen, \& van der Leij, 2014; van der Sluis, de Jong, \& van der Leij, 2004). A unique effect of phonological skills on math skills has also been reported (De Smedt \& Boets, 2010; Krajewski \& Schneider, 2009; Simmons \& Singleton, 2008), even after controlling for reading skills (Hecht, Torgesen, Wagner, \& Rashotte, 2001). It has also been suggested that a major part of the shared variance between reading and math performance is explained by RAN among children with RDs and MDs (Geary, 1993; Geary, Hamson, \& Hoard, 2000), or by phonological processing and RAN in an unselected sample (Hecht et al., 2001). However, not all studies have supported the unique link between RAN and math. In some studies, the effect of RAN on math performance disappeared after other relevant cognitive variables (such as reading, IQ, attention, or processing speed) were controlled (Georgiou, Tziraki, Manolitsis, \& Fella, 2013; Landerl et al., 2009; Moll, Göbel, Gooch, Landerl, \& Snowling, 2014; Willcutt et al., 2013; Willburger, Fussenger, Moll, Wood, \& Landerl, 2008). Similarly, not all studies have supported a unique connection between PA and math skills when reading performance has been controlled (Durand, Hulme, Larkin, \& Snowling, 2005; van Bergen et al., 2014; Willcutt et al., 2013).

In regard to attention deficit, phonological skills and $\mathrm{AD}$ seem not to be related (Gooch, Snowling, \& Hulme, 2011; McGee, Brodeur, Symons, Andrade, \& Fahie, 2004; Purvis \& Tannock, 2000; Willcutt et al., 2001). Instead, a link between naming speed deficit and attention deficit has been suggested (Tannock, Martinussen, \& Frijters, 2000), especially for children with AD without impulsivity and hyperactivity (Arnett et al., 2012; Hynd et al., 1991; Thomson et al., 2005). Some studies suggest that naming speed deficits are most severe in the comorbid group with RDs and AD (Bental \& Tirosh, 2007; Rucklidge \& Tannock, 2002). However, in many studies that controlled for reading, a connection between RAN and attention was not evident (Ackerman \& Dykman, 1993; Felton \& Wood, 1989; Raberger \& Wimmer, 2003; SemrudClikeman, Guy, Griffin, \& Hynd, 2000) or the attention deficit hyperactivity disorder (ADHD) group outperformed the RD group in RAN (Felton, Wood, Brown, Campbell, \& Harter, 1987; Närhi \& Ahonen, 1995; Willcutt, Betjemann, et al., 2010). 
To our knowledge, only three studies have investigated the double-deficit hypothesis and included measures for attention and/or math. First, Ackerman and colleagues (2001) explored double deficits in children with RDs. The researchers found RAN had only a minor effect on RDs after PA was controlled. The researchers also showed that comorbid problems in mathematics were common in a sample with RDs and that RAN was significantly correlated with math performance, attention ratings, and processing speed. However, reading was measured based on accuracy only. Second, Waber, Forbes, Wolff, and Weiler (2004) investigated whether groups based on the double-deficit hypothesis showed differences in other skills than reading. A group for single phonological deficit was not found, but the three groups (DD, NSD, and NoD) differed in several skills, such as motor, visuospatial, or oral language skills. However, there were no group differences in attention. It was suggested that because RAN and PA seemed to be linked to skills other than reading, it was probable that learning problems other than reading were accumulated in the double-deficit group. However, in Waber and colleagues' (2004) study, RD was defined based solely on word reading accuracy, and measures for math skills were not included in the study. In a third study (Torppa et al., 2013), an unselected sample of Finnish children was explored in the framework of DDH including measures for attention and using reading measures based on fluency. The results showed more attention deficits in the double-deficit group indicating that they were more prone to comorbid problems.

\subsection{The present study}

In this study, we examine the DDH in Finnish, which is at the extreme transparent end of the transparency continuum of orthographies (see Seymour et al., 2003). Our sample consisted of children who were all diagnosed with learning difficulties, and the majority of the children have RDs. In a clinical sample, measures that typically reach ceiling in transparent orthographies (i.e., reading accuracy and PA) may still show variance, especially with tasks complex enough (Caravolas, Volín, \& Hulme, 2005; De Jong \& van der Leij, 2003; Landerl, Wimmer, \& Frith, 1997; Trenta, Benassi, Di Filippo, Pontillo, \& Zoccolotti, 2013). Although the DDH has been shown to predict RD in Finnish (Torppa et al., 2012, 2013), we extended the focus from RDs to comorbidity with mathematical disabilities and attention deficit. The use of a clinical sample ensures that the sample includes children with severe learning difficulties. To further broaden the scope of previous studies, we include accuracy and rate aspects in reading assessment, which is a more relevant approach in transparent orthographies. Majority of the previous studies investigating the connection of RAN and PA with math or attention performance have either not controlled the effect of reading at all or used accuracy only. Thus, the connections found may be mediated by reading fluency. 
The research questions of this study are as follows: (a) Will the assumptions of the double-deficit hypothesis be replicated in a clinical sample with comorbid deficits in reading, math, and attention? If RAN and PA are independent and additive contributors behind RD, it is expected that the correlation between RAN and PA is modest, RAN and PA differ from each other in their relation to reading and spelling performance, the groups based on the double-deficit hypothesis (DDH groups) differ in reading and spelling abilities, and the reading disabilities are most severe and the prevalence of RDs is greatest in the DD group. (b) Do the DDH groups differ in math performance or attention ratings? Group differences in these measures would indicate that deficits in PA and/or RAN were not restricted only to reading and spelling domains. (c) Is the comorbidity of RD, MD, and AD linked to the prevalence of PD, NSD, and DD? If RAN and PA have a unique link with MDs and AD excluding reading, the frequency of $\mathrm{PD}, \mathrm{NSD}$, and $\mathrm{DD}$ should be high in comorbid groups with RDs, MDs, and AD. However, if the connection of NSD and $\mathrm{PD}$ with MDs and $\mathrm{AD}$ is mediated by reading ability, the prevalence of NSD, PD, and DD will be higher only in the groups with RDs. 


\section{METHODS}

\subsection{Participants}

The clinical database used in this study consisted of children referred to a child neuropsychological clinic for closer evaluation of learning disabilities or of the need for neuropsychological intervention. Children were referred by a psychologist or special health care services after basic examination of cognitive skills and learning disabilities conducted by a psychologist. All children had an acknowledged specific learning disability and all of them had received special education services in school: $7 \%$ of children were placed in small groups and $25 \%$ of children had Individualized Education Program in some of the school subjects; $20 \%$ of the children had been retained in school. Some children received additional services like speech therapy or occupational therapy. After applying the exclusion criteria of native language other than Finnish, score below 80 in both verbal and performance IQ on the Wechsler Intelligence Scale for Children (WISC-R or WISC-III; Wechsler, 1974, 1991), or a child's neurological disorder reported by parents, the resulting sample consisted of 205 children. All children were affected by single or comorbid disabilities in reading (RDs, $n=158$ ), math (MDs, $n=96$ ), and/or attention (AD, $n=78$ ) (see the criteria for definitions, and see Figure 1 for the comorbidity of RDs, MDs, and AD where areas represent the proportion of children in each sector). All children came from central Finland, and the distribution of the educational level of their parents was comparable to the Finnish population. The mean age of the sample was 10 years 4 months (standard deviation 13 months, range $=8$ years 0 months to 13 years 8 months), and the proportion of boys was $62 \%$. Information on the general cognitive ability, phonological skills, RAN, academic performance, and evaluation of the attention for the sample is presented in Table 1. 
FIGURE 1 Combinations and comorbidity of reading disabilities (RD), math disabilities (MD), and attention deficit (AD).

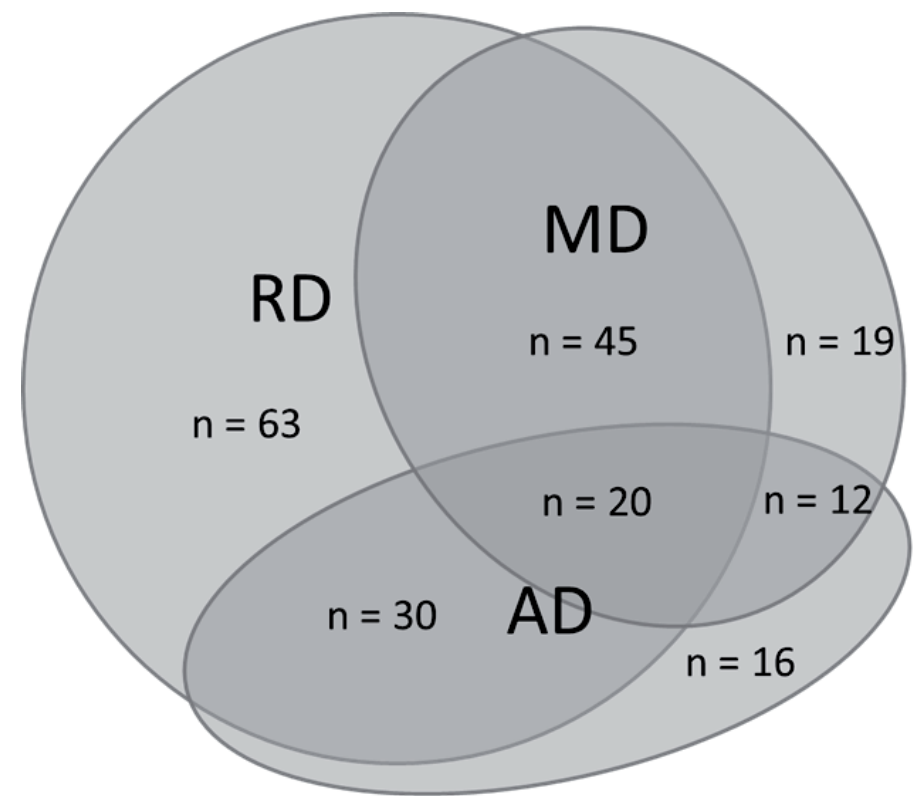

\subsection{Measures}

All measures used in this study were obtained from the neuropsychological assessment of the children, with the exception of attention, which was evaluated by the teachers and parents of the child. The typical assessment procedure took place over the course of two 3-hour sessions. Measures with available normative data (IQ, RAN, PA, reading fluency, and spelling) were standardized according to the published norms for age level, and z-scores were used in the analyses.

IQ. The total score on the Wechsler Intelligence Scale for Children (WISCR or WISC-III; Wechsler, 1974, 1991) was used as a measure for intelligence.

Rapid Automatized Naming. RAN was assessed using letters $(\mathrm{O}, \mathrm{A}, \mathrm{S}, \mathrm{T}, \mathrm{P})$ and digits $(2,4,6,7,9)$ from a Finnish version of the test of rapid automatized naming (Ahonen, Tuovinen, \& Leppäsaari, 1999). The stimulus cards consisted of a total of 50 items arranged in five rows. Each of the five items was repeated in pseudorandom order; none of the items were presented successively. The mean of the letter and number naming times $(\mathrm{r}=.789)$ was standardized according to age and used as the RAN score. Cronbach's alpha for the letter and digit naming rate based on standardized items in the sample used in this study was $\alpha=.882$ (compare $\alpha=.892$ in normative sample). 
Phonological awareness. For phonological awareness, we used the Phonological Processing subtask of the Developmental Neuropsychological Assessment (NEPSY; Korkman, Kirk, \& Kemp, 1997). It consists of tasks for phoneme or word segment deletion and replacement (maximum score of 36). For children under 9 years of age, the task begins with a subtask in which child must identify one of the three pictures that contains the word segment the experimenter says. The standardized score of correct answers was used as the PA score. Cronbach alpha for this task is reported to be .97 in a normative sample.

Reading fluency. Reading fluency (i.e., a combined measure for reading accuracy and rate) was defined with a standardized time-limited word list reading (Häyrinen, Serenius-Sirve, \& Korkman, 1999). Children were instructed to read the words aloud as accurately and quickly as possible. The standardized score from number of words read correctly within 2 minutes was used as an outcome score.

Reading accuracy and rate. In addition to the measure for reading fluency, we included separate accuracy and rate measures. In the absence of normative data for the separate accuracy and rate measures, age was controlled in the statistical analysis of these measures. The separate composites for reading accuracy and rate were formed of three measures: word list reading, pseudoword list reading, and age appropriate informational text reading (Niilo Mäki Institute, 2004). The word and pseudoword lists consisted of 20 items with a varying length (from 4 to 18 letters), including multimorphemic words and structures requiring decoding of phonemic length (e.g., words like veneeseen and lannistumatonta, and pseudowords like tapekkaat and kaalluspastikki), which are problematic for Finnish dyslexic readers (Pennala et al., 2010) and adults with poor reading skills (Lyytinen, Leinonen, Nikula, Aro, \& Leiwo, 1995). In all tasks, the children were instructed to read aloud as quickly and accurately as possible from the beginning to the end. Reading accuracy was defined as the mean percentage of accurately read items of these three measures. Cronbach's alpha for the accuracy score based on the three standardized tests was $\alpha=.787$ and the correlations between accuracy measures controlled for age varied between .51 and .55 . The accuracy for text reading was high $(M=93 \%, S D=6 ; 66 \%$ of the sample exceeding $90 \%$ accuracy), whereas for words and pseudowords, there was more variation ( $M=82 \%, S D=15, M=70 \%, S D=18$, respectively). For the reading rate, the completion time for word list reading, pseudoword list reading, and text reading was measured. For each task, the number of items read per minute was calculated, and the mean rate of the three tasks served as a measure for the reading rate (Cronbach alpha based on standardized items, $\alpha$ $=.899$, correlations controlled for age varied between .69 and .84 ).

Spelling accuracy. Spelling accuracy was defined by a standardized dictation task with 20 items with increasing difficulty (Häyrinen et al., 1999). For second graders, the items were words, and for older children, the items consisted of words and phrases. The standardized score of words spelled correctly was used as a score for spelling. 
Math skills. Math skills were assessed with a time-limited test of arithmetic fluency containing multidigit calculations from all four basic operations, RMAT (Räsänen, 2004). The Cronbach alpha for the RMAT is reported to be .92-.95 in a normative sample, depending on the school grade. If the RMAT score was not available, a subtest for arithmetic from another standardized test battery (Häyrinen et al., 1999) was used for the MD definition $(n=10)$. For analyses of variance, a raw RMAT score was used, with age controlled.

Attention. Attention problems were evaluated with the scale for Attentiondeficit/hyperactivity problems in the Child Behavior Checklist (CBCL) filled in by the child's parents or the Child Behavior Checklist Teacher's Report Form (TRF) filled in by the child's primary school teacher (Achenbach \& Rescorla, 2001). For the attention scale, the CBCL has seven and the TRF 13 statements, which are rated as three categories $(0=$ not true, $1=$ somewhat or sometimes true, and $2=$ very true or often true). In the absence of published local norms, the raw scores were changed to $t$ scores based on U.S. norms (Achenbach \& Rescorla, 2001), and the mean score of the available assessments was used as in the analyses (Cronbach alpha based on standardized items, $\alpha=.754$ ).

\subsubsection{Criteria for $\mathrm{DDH}, \mathrm{RD}, \mathrm{MD}$, and $\mathrm{AD}$ categorization.}

The criterion for naming speed deficit was a RAN performance 1.0 SD below the normative mean for age. For phonological awareness, a criterion for phonological deficit was a mean accuracy score 1.0 SD below the normative mean for age. Based on these criteria, four groups according to the DDH were formed: $\mathrm{DD}, \mathrm{NSD}, \mathrm{PD}$, and NoD.

The criterion used for classifying RD and MD was the performance level 1.0 SD below the normative mean for the grade. The criteria were based on an efficiency score, that is, the number of correct responses within a time limit. A cutoff of $t$ score greater than 60 (i.e., $16^{\text {th }}$ percentile in U.S. norms; Achenbach \& Rescorla, 2001) on the Attention scale on either the parental or teacher evaluation in the Child Behavior Checklist served as the criterion for AD.

\subsubsection{Analysis Overview}

Outliers that deviated from the distribution (more than 2.5 SD below the mean of the sample) in text reading accuracy $(n=4)$, phonological awareness $(n=2)$, and RAN $(n=6)$ were moved to the tail of the distribution in their original order to avoid bias in the analyses. The distributions of the RAN, PA, reading, and spelling measures were skewed (with an exception for reading fluency measure, which did not need any adjustments) and were normalized with transformations: RAN with natural logarithm and PA, reading, and spelling with square root transformation. Measure for attention was skewed (floor effect) in spite of the attempts with square root or natural logarithmic transformation. The descriptive statistics for the measures before transformations are reported in Table 1. 
The between-group analyses were performed with analyses of variance (ANOVA). First, the performance in RAN and PA (dependent variables) in the DDH groups (fixed factors) were compared to verify the grouping based on double-deficit hypothesis and to address the concern that possibly lower performance in the double-deficit group may be due to the more severe PD and NSD in this group compared to single-deficit groups (Schatschneider et al., 2002).

In the second set of analyses, the effects of phonological deficit and naming speed deficit on reading, spelling, and math skills were examined with ANCOVA, with age set as the covariate. First, phonological deficit (deficit, no deficit) and naming speed deficit (deficit, no deficit) were included as separate fixed factors in order to examine their main effects and interaction effect. Second, pairwise comparisons of the four DDH subgroups (DD, NSD, PD, NoD) were conducted. Since the attention measure was skewed and not possible to normalize with the transformations, the between-group analyses including attention were conducted with the Kruskal-Wallis test.

Finally, the prevalence and comorbidity of RDs, MDs, and AD were computed in the DDH groups. Groups for different combinations of RDs, MDs, and $\mathrm{AD}$ (LD groups) were cross-tabulated with the $\mathrm{DDH}$ groups. 


\section{RESULTS}

\subsection{Comparison of age, gender, IQ, phonological awareness, and RAN in the DDH groups}

Age and IQ in the DDH groups (DD, $n=90$; NSD, $n=48$; PD, $n=37$; NoD, $n=$ 30) were compared with ANOVA, and gender distribution was explored with cross-tabulation (Gender $\times$ DDH Groups). The DDH groups did not differ from each other in any of these measures (see Table 1). Results from the group comparisons in PA and RAN showed that the DD group did not have more severe deficits in PA and RAN than the single-deficit groups. Accordingly, the singledeficit groups were well-matched with the NoD group since there was no difference between the NSD group and the NoD group on PA, and there was no difference between the PD group and the NoD group on RAN (Table 1).

The correlations (see Table 2) confirmed the group comparison results. The correlation between PA and RAN was not significant. PA was most strongly related to reading and spelling accuracy and RAN to reading fluency and rate.

\subsection{Comparison of reading and spelling in the DDH groups}

In group comparisons of reading fluency (ANCOVA, age as a covariate), the main effect of NSD status (deficit, no deficit) on reading fluency was statistically significant, $F(1,164)=5.41, p=.021, \eta^{2}=.032$. Neither the main effect of phonological deficit status (deficit, no deficit) nor the interaction between NSD and PD status was significant. The pairwise comparisons of the four DDH groups in reading fluency revealed that the DD group performed significantly worse than all the other groups. 


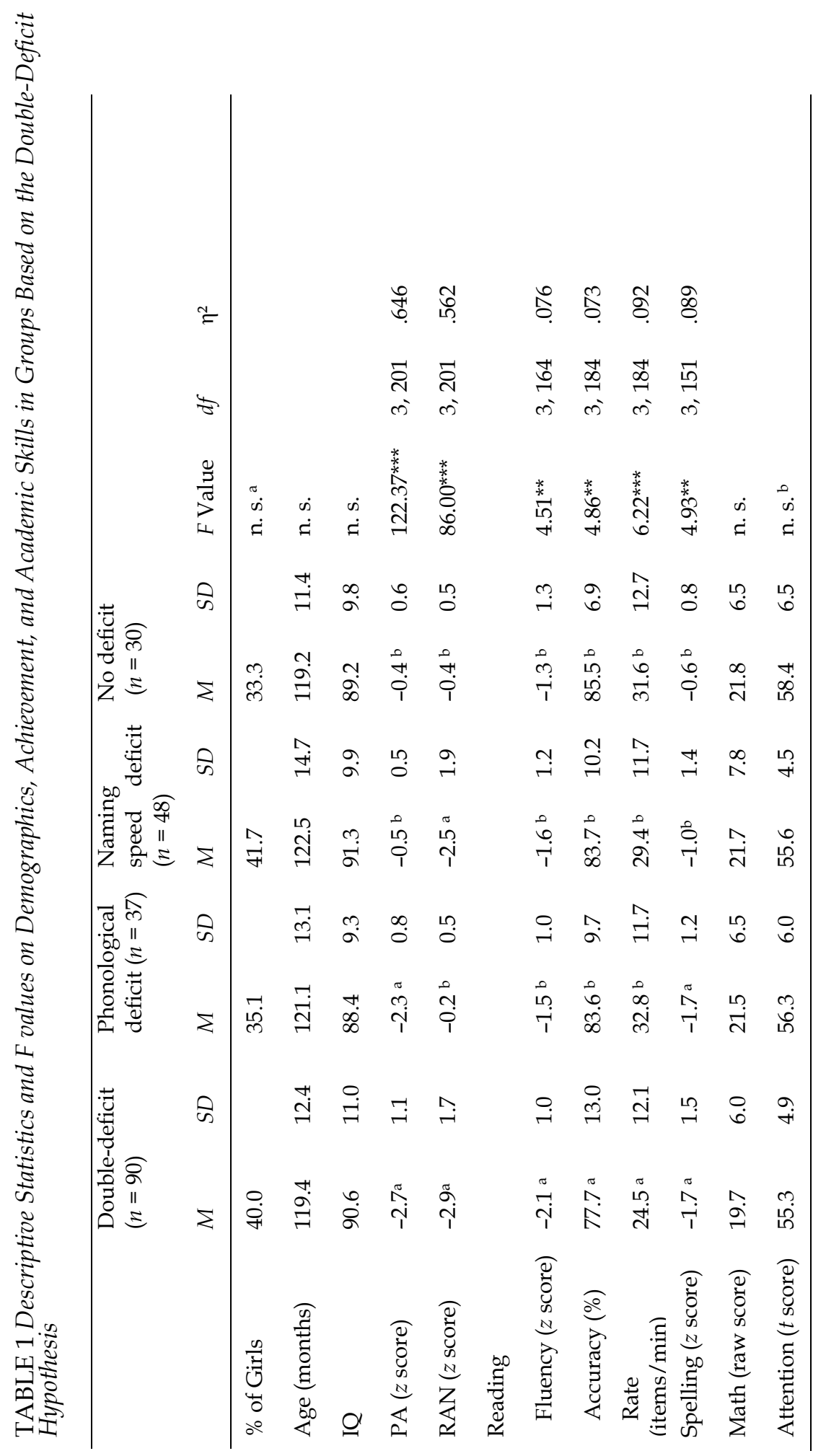


TABLE 2 Correlations Among Tasks Controlling for Age

\begin{tabular}{lllllllll}
\hline Variable & 1 & 2 & 3 & 4 & 5 & 6 & 7 & 8 \\
\hline 1. PA & & & & & & & & \\
2. RAN & .14 & & & & & & & \\
3. Reading Fluency & $.18^{*}$ & $.30^{* * *}$ & & & & & & \\
4. Reading Accu- & $.19^{* *}$ & $.16^{*}$ & $.42^{* * *}$ & & & & & \\
racy & & & & & & & & \\
5. Reading Rate & .12 & $.38^{* * *}$ & $.58^{* * *}$ & $.32^{* * *}$ & & & & \\
6. Spelling & $.36^{* * *}$ & .01 & $.32^{* * *}$ & $.44^{* * *}$ & .10 & & & \\
7. Math & $.18^{*}$ & .09 & .04 & .12 & .04 & .04 & & \\
9. Attention & .04 & .12 & $.20^{* *}$ & .01 & .08 & .03 & .05 & \\
\hline
\end{tabular}

Note. Variables are coded by numbers in table head. PA = phonological awareness,

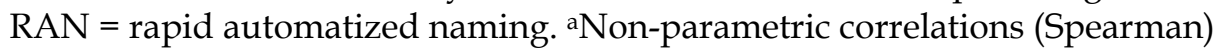
${ }^{*} p<.05,{ }^{* *} p<.01,{ }^{* * *} p<.001$.

Group comparisons of reading accuracy (ANCOVA, age as a covariate) revealed that NSD status, $F(1,184)=4.82, p=.029, \eta^{2}=.026$, and PD status, $F(1,184)=3.95, p=.048$, $\eta^{2}=.021$ had significant main effects, but the NSD $\times$ PD interaction was not significant. The pairwise comparisons for the four DDH groups revealed that the DD group performed significantly worse in reading accuracy than all the other groups. No other group comparisons were significant.

Group comparisons of the reading rate (ANCOVA, age as a covariate) revealed that NSD status, $F(1,184)=10.62, p=.001, \eta^{2}=.055$, had a significant main effect. Neither the main effect for PD status nor the NSD $\times$ PD interaction was significant. Pairwise comparisons for the four DDH groups revealed that there were significant group differences between the DD group and all other groups in reading rate. No other group comparisons were significant.

Group comparisons of spelling (ANCOVA, age as a covariate) revealed that PD status had a significant main effect, $F(1,151)=13.43, p<.001, \eta^{2}=.082$. NSD status had no significant main effect, and there was no NSD $\times$ PD interaction. Pairwise comparisons showed that the DD and PD groups performed worse than the NSD and NoD groups in spelling. To insure that the results found in analyses of variance were not reached due to the alterations made for the data (transformations, covarying the age), the data was reanalyzed with untransformed data and with nonparametric methods where normal distribution was not required nor age controlled. The results of these analyses paralleled the ones reported here.

\subsection{Prevalence of RDs in the DDH groups}

To explore the prevalence of RDs in the $\mathrm{DDH}$ groups, cross-tabulation with the $\mathrm{DDH}$ groups (DD, NSD, PD, NoD) and RD status (RD, no RD) was conducted. The crosstabulation revealed a significantly greater prevalence of RDs in the DD group (90\%, adjusted standardized residual $=3.9$ ) and significantly smaller in the NoD group 
$(53 \%$, adjusted standardized residual $=-3.3)$ than expected, $\chi^{2}(3)=19.49, p<.001$. There was comparable prevalence of RDs in the single-deficit groups $(73 \%$ in the PD group and $71 \%$ in the NSD group). The prevalence of RDs in the NoD group (53\%), however, was remarkably greater than expected in the normative group $(17 \%$, equivalent of the 1.0 SD cutoff from the normative mean, which was a criterion for RDs in this study), a result that was predictable in the clinical sample.

\subsection{Comparison math skills and attention in the DDH groups}

To examine whether the DDH group differences were not restricted only to reading and spelling skills, the DDH groups were compared regarding their math performance and attention ratings. Group comparisons of math performance (ANCOVA, age as a covariate) revealed no significant main effect for NSD or PD status, and no significant PD status $\times$ NSD status interaction. Similarly, the group comparisons for attention (Kruskal-Wallis test) revealed no differences between the DDH groups in attention.

\subsection{Prevalence of MDs and AD in the DDH groups}

To explore the prevalence of MDs and $\mathrm{AD}$ in the $\mathrm{DDH}$ groups, cross-tabulations with the DDH groups (DD, NSD, PD, NoD) across MD status (MD, no MD), and with the $\mathrm{DDH}$ groups across $\mathrm{AD}$ status $(\mathrm{AD}$, no $\mathrm{AD}$ ) were conducted. The results revealed an equal distribution across the sample in both analyses; thus, $\mathrm{AD}$ and MDs were not related to the DDH grouping.

\subsection{DDH groups and comorbidity of RDs, MD, and AD}

To explore the link of comorbidity of RDs, MDs, and AD to the DDH, groups presenting different kind of combinations of reading, math, and attention problems were formed (comorbidity groups). As can be seen in Figure 1, the comorbidity of RDs, MDs, and AD was high overall. Roughly $50 \%$ of the children in this sample fulfilled the criteria for more than one disability.

Cross-tabulation for the DDH groups and the comorbidity groups revealed an uneven cell distribution (see Table 3) indicating that double deficits were less pronounced in groups without RD (13-25\%) than in groups with RD (43-55\%). Thus, the results from the comorbidity groups as well as pairwise correlations between measures suggest that DD seems to be related especially to RDs but not to MDs or AD. 
TABLE 3 Cross-tabulation of LD Groups and DDH Groups

\begin{tabular}{|c|c|c|c|c|c|c|}
\hline LD group & $\begin{array}{c}\text { Double- } \\
\text { deficit }\end{array}$ & $\begin{array}{c}\text { Phonological } \\
\text { deficit }\end{array}$ & $\begin{array}{c}\text { Naming } \\
\text { speed deficit }\end{array}$ & No deficit & $\chi^{2}$ & $\Phi$ \\
\hline \multirow[t]{2}{*}{$\mathrm{RD}+\mathrm{MD}+\mathrm{AD}$} & 10 & 4 & 5 & 1 & $29.7^{*}$ & $0.38^{*}$ \\
\hline & $(0.6)$ & $(0.2)$ & $(0.2)$ & $(-1.3)$ & & \\
\hline \multirow[t]{2}{*}{$\mathrm{RD}+\mathrm{MD}$} & 25 & 7 & 9 & 4 & & \\
\hline & (1.8) & $(-0.5)$ & $(-0.6)$ & $(-1.2)$ & & \\
\hline \multirow[t]{2}{*}{$\mathrm{RD}+\mathrm{AD}$} & 13 & 5 & 7 & 5 & & \\
\hline & $(-0.1)$ & $(-0.2)$ & $(0.0)$ & $(0.3)$ & & \\
\hline \multirow[t]{2}{*}{$\mathrm{RD}$} & 33 & 11 & 13 & 6 & & \\
\hline & (1.6) & $(-0.1)$ & $(-0.6)$ & $(-1.4)$ & & \\
\hline \multirow{2}{*}{$\mathrm{MD}+\mathrm{AD}$} & 3 & 1 & 4 & 4 & & \\
\hline & $(-1.4)$ & $(-0.9)$ & $(0.8)$ & (1.9) & & \\
\hline \multirow[t]{2}{*}{ MD } & 4 & 5 & 7 & 3 & & \\
\hline & $(-2.1)$ & $(1.0)$ & (1.5) & $(0.1)$ & & \\
\hline \multirow[t]{2}{*}{$\mathrm{AD}$} & 2 & 4 & 3 & 7 & & \\
\hline & $(-2.6)$ & $(0.8)$ & $(-0.5)$ & (3.4) & & \\
\hline
\end{tabular}




\section{DISCUSSION}

In this study, the double-deficit hypothesis (DDH) was examined in a Finnish clinical sample of children with various combinations of developmental difficulties in reading, math, and/or attention. The specificity of PA and RAN to reading was examined by analyzing whether difficulties in PA and RAN were linked to RDs, MDs, or $\mathrm{AD}$, or to comorbid difficulties. Our findings partly supported the DDH and gave further support for specificity of the connection between RAN, PA, and reading.

We found a partial support for the double-deficit hypothesis (Wolf \& Bowers, 1999) as the DD group with deficits in PA and RAN performed significantly poorer in reading accuracy, rate, and fluency relative to all the other groups. However, in contrast to the expectation that the single-deficit groups would show different manifestations of reading deficits (NSD poor in reading fluency and rate and PD group in reading accuracy), single-deficit groups did not differ from each other nor from no deficit group in reading skills. The only difference between single-deficit groups was the poorer performance of PD group than NSD or NoD group in spelling. The result that reading skills were similar in the single-deficit and NoD groups indicates either that the combination of NSD and PD had the most dramatic negative effects on reading performance whereas the negative effect of single deficits may to some extent be compensated or that in clinical samples there are other additive predictors over PA and RAN that hinder the reading performance. The finding for the lowest performance in DD group was not due to the poorer performance in PA and RAN compared to single-deficit groups in this sample, a concern raised by Schatschneider et al. (2002). In accordance with our hypothesis, the prevalence of RDs was higher in the DD group (90\%) compared to the single-deficit groups (both around $70 \%$ ) and the NoD group (53\%). In the present sample of children who were referred to clinic due to their difficulties in learning, the prevalence of RDs was significantly higher even in the NoD group (53\%) than expected in the normative sample with 1.0 SD cutoff $(17 \%)$. It follows that even though double deficits unquestionably had the closest link to RDs, there were also children who had RDs without PD or NSD ( $10 \%$ of the children with RDs in this study, $n=16$ ). Because a proportionally large number of children in this sample had poor reading skills regardless of the children's position in the DDH grouping, multiple problems (e.g., cognitive, socioemotional, motiva- 
tional, mental) that are manifest in clinical samples might cause problems in literacy skills over and above PA and RAN in all groups.

PA and RAN had unique connections with reading and spelling skills so that PD status (deficit, no deficit) had a significant main effect on reading accuracy and spelling but not on reading rate or fluency. NSD status had a significant main effect on reading accuracy, rate, and fluency, but not on spelling. The correlations showed the parallel trend: PA was most strongly related to reading and spelling accuracy (and also to fluency which was defined as a rate of accurate responses), whereas RAN was especially linked with reading fluency and rate. These results were in accordance with several previous studies from various orthographies (Compton et al., 2001; Cornwall, 1992; Furnes \& Samuelson, 2010; Kairaluoma et al., 2013; Landerl \& Wimmer, 2008; Moll, Ramus et al., 2014; Papadopoulos et al., 2009; Pennington et al., 2001; Schatschneider et al., 2002; Sunseth \& Bowers, 2002; Torppa et al., 2012; 2013; Vaessen et al., 2009; Wimmer et al., 2000). However, the results presented above do not give a full closure to the discussion as single PD and NSD groups did not differ in any other aspect of literacy than spelling, which is in contrast to some previous findings from transparent orthographies. Wimmer et al., (2000) for example showed that the two single-deficit groups differed from each other in reading rate. This may be partly due to the power lost in analyses with dichotomous variables compared to the continuous ones (Branum-Martin, Fletcher, \& Stuebing, 2013; Compton et al., 2001; Schatschneider et al., 2002) but also due to the sample (normative vs. RD, see Kirby et al., 2010; McBride-Chang \& Manis, 1996; Meyer, Wood, Hart, \& Felton, 1998; cf. Katzir et al., 2006). Even though some questions on this concern are left unanswered, the results of the present study, along with the increasing research evidence from various orthographies, support the importance of including both reading accuracy and rate measures in studies on reading development, reading disability, and double deficits (discussed e.g. in Moll, Ramus, et al., 2014; Papadopoulos et al., 2009).

The second main part of this study explored the comorbidity of RDs, MDs, and $\mathrm{AD}$ in the context of the double-deficit hypothesis. The results of this study support the view of a specific connection of RAN and PA with reading and spelling difficulties. First, the DDH groups differed from each other especially by reading ability, not by math performance or attention ratings. Second, the prevalence of double deficits was higher in the comorbidity groups (i.e., groups with different combinations of RDs, MDs, and AD) with RDs but not in the comorbidity groups without RDs. Third, RAN and PA were correlated with reading and spelling measures but not with math performance or attention ratings (with the exception of a small but significant correlation between PA and math). Based on these results, the deficits in naming speed and phonological awareness are related to RDs, but not to MDs, AD, or the comorbidity of RDs, MDs, and AD. These results are in line with several studies in which RAN and/or PA were specifically linked with reading, not with math or attention in normative populations (Durand et al., 2005; Georgiou et al., 2013) as well as in children with RDs, MDs, and/or AD (Denckla \& Rudel, 1976; Fletcher, 2005; Heikkilä et al., 2009; Landerl et al., 2009; Moll, Göbel, \& Snowling, 2014; Willburger et al., 2008; Willcutt, Betjemann et al., 2010; Willcutt et al., 2013; Wise et al., 2008). These results support the view that in explaining the comorbidity of RDs, MDs, and AD, predictors other than RAN and PA seem to be more essential. There are candidates such as 
processing speed (Boada et al., 2012; Compton, Fuchs, Fuchs, Lambert, \& Hamlett, 2012; McGrath et al., 2011; Willcutt, Betjemann et al., 2010; Willcutt, Pennington, et al., 2010; Willcutt et al., 2013) and short-term memory (Landerl et al., 2009; Willcutt et al., 2013), which were not included in this study but should be in the scope of further studies. Because many previous studies have found significant connections between RAN or PA and math or attention, the results are discussed next in more detail.

In contrast to previous studies (Ackerman et al., 2001; Koponen et al., 2007; 2013; van Bergen et al., 2014; van der Sluis et al., 2004), we failed to find a link between RAN and math skills even though both measures were timed and even though digits were included in a composite measure of RAN, which usually increases the correlation between these tasks (Hart, Petrill, Thompson, \& Plomin, 2009; Landerl, Bevan, \& Butterworth, 2004; Willburger et al., 2008). There are possible explanations for the nonexistent connection between RAN and math. First, the type of reading measure used may have had an effect on the results. In previous studies where RDs were defined based on reading fluency rather than accuracy, the group with MDs alone did not differ from the control group in RAN (Landerl et al., 2009; van der Sluis et al., 2004, however, see Koponen et al., 2013; van Bergen et al., 2014), and RAN has been uniquely associated with RDs but not MDs (Georgiou et al., 2013; Landerl et al., 2009; Willburger et al., 2008; Willcutt et al., 2013). Second, the connection between RAN and calculation may be stronger in normative samples than in the RD group (Koponen et al., 2013). This may partly explain why the RAN-calculation association was weaker in this study (the majority of the children had RDs) than the association observed in studies conducted with unselected groups (Koponen et al., 2007; van der Sluis, de Jong, \& van der Leij, 2007) or those in which normative and RD groups were analyzed together (van Bergen et al., 2014). Third, the connection between RAN and calculation may diminish with development (Hecht et al., 2001; Mazzocco \& Grimm, 2013) and thus may not be significant in children after the primary grades, the group that formed the majority of this sample. Finally, the result may be at least partly explained by the characteristics of the math task. Although RAN seems to be a strong predictor of simple arithmetic fluency that relies on retrieval skills (e.g., counting, calculation in single-digit tasks), the connection has been weaker with more complex calculation tasks (Hecht et al., 2001; Koponen et al., 2007, 2013) like the one used in this study. In sum, our results support the notion that RAN has no unique connection with more complex math skills in a sample with a great representation of RDs when RD was defined based on reading fluency. The small but significant correlation between math performance and PA is in line with previous studies (De Smedt \& Boets, 2010; Krajewski \& Schneider, 2009; Simmons \& Singleton, 2008) but as this connection was not very strong and PA did not seem to have any significant main effects for math performance, our results support the conclusion that PA was more closely connected to literacy skills than to math performance. In future studies, the concerns raised above on sample selection, measures, and developmental changes should be addressed.

Although many scholars have found a connection between attention and RAN (Arnett et al., 2012; Hynd et al., 1991; Tannock et al., 2000; Thomson et al., 2005), we failed to find a link between the two. Our results support the view that RAN is espe- 
cially linked with reading and RDs, not with attention deficit. The difference between these previous results and the results of this study may derive from the fact that in many studies investigating the link between attention and RAN, reading was not controlled, or was measured only with an accuracy measure, which leaves the common variance of RAN and reading fluency uncontrolled. Thus, the results of this study are in line with studies in which no connection between RAN and attention was found when reading was controlled (Ackerman \& Dykman, 1993; Felton \& Wood, 1989; Raberger \& Wimmer, 2003; Semrud-Clikeman et al., 2000; see also Boada et al., 2012 for review). The results of this study also confirmed the findings of previous studies where no connection between PA and attention was found (Gooch et al., 2011; McGee et al., 2004; Purvis \& Tannock, 2000, Willcutt et al., 2001).

Several practical implications for evaluating and treating reading disabilities can be derived from the results of this study. First, in assessing reading disabilities, the knowledge that RAN and PA are linked with unique aspects of reading gives an additional tool for identifying RDs early and provides relevant information when planning interventions for children with RDs. Deficits in RAN are associated with problems in reading fluency, and the intervention could be targeted at automatizing reading skills. Phonological deficits instead are connected with problems in reading and spelling accuracy especially in the initial stage of reading acquisition, whereupon the intervention could primarily emphasize basic decoding and spelling skills. Children with a double deficit have a greater risk for more severe reading disabilities than children with a single deficit in PA or RAN. Since measures for PA and RAN have been shown to predict reading skills before schooling (Papadopoulos et al., 2009; Puolakanaho, Poikkeus, Ahonen, Tolvanen, \& Lyytinen, 2004; Puolakanaho et al., 2008; Torppa et al., 2012, 2013) and the groups based on DDH appear to be relatively stable across the first school years (Steacy et al., 2014), preventive interventions could be targeted especially at this group of children with the greatest risk of RD.

Second, consistent with previous findings from transparent orthographies reading accuracy of age-appropriate text was high (93\%) even in a clinical sample that showed a high prevalence of RDs. Our results for the children with learning difficulties thus solidify the results of previous studies in transparent orthographies with unselected samples (Aro \& Wimmer, 2003; Landerl \& Wimmer, 2008; Seymour et al., 2003), since the RDs were manifested primarily as fluency problems with relatively high accuracy in age-appropriate reading material.

Finally, even though RAN and PA seem to be especially connected to RDs and not to explain the comorbidity of disabilities in reading, math, or attention, the high comorbidity of these disorders should be acknowledged in learning assessment and intervention planning. As DuPaul and colleagues (2013) have suggested, screening of academic problems as well as the problems in attention should always be included in assessment of children with LDs or with attention problems. Even though these deficits probably have a shared genetic basis (e.g., Willcutt, Pennington, et al., 2010), they have unique characteristics that should be acknowledged in the intervention since different combinations of learning problems may respond differently to intervention (Boada et al., 2012; Fuchs et al., 2013). For example, for children with comorbid RDs and $\mathrm{AD}$, including components of attention training in intervention 
may also benefit reading skills (Aro, Ahonen, Tolvanen, Lyytinen, \& de Barra, 1999; see Sexton et al., 2012 for a review).

As in all clinical samples, limitations affect the generalizability of the results. Especially notable is that the comorbidity rate may be inflated because children with multiple deficits may be more likely to be referred for evaluation and intervention (Semrud-Clikeman et al., 1992; Waber et al., 2003), especially those with hyperactive and impulsive types of attention problems (Willcutt \& Pennington, 2000). Thus, generalizing these results outside clinical samples may lead to overemphasis on comorbidity. Other types of referral bias may also be involved, and it is possible that some disabilities are overemphasized in the sample (e.g., prevalence of RDs in this study seems to be relatively large compared to the prevalence of MDs and AD). This also leads to methodological problems since many of the comorbidity groups without RDs were small and only trend-level analyses for comorbidity could be made. Second, we are aware that categorizing continuous variables such as RAN or reading in dichotomous groups reduces the power to detect relationships between variables. However, unreported regression analyses conducted with the data revealed the same pattern reported here.

In this study, the issue of comorbidity of RDs, MDs, and AD was explored in the framework of the double-deficit hypothesis for the first time. In contrast to many studies that have explored comorbidity, reading fluency was used as a definition for RD. Since RAN has been associated more strongly with reading fluency than with reading accuracy, a fluency based definition for RD may alter the associations found between RAN and learning difficulties, revealing stronger connection between RAN and RD than between RAN and MD or AD. In future studies searching for the predictors for comorbidity between these deficits, the scope should shift more towards the multiple deficit explanations of learning disabilities (Pennington, 2006; 2012) and include more protective and risk factors in addition to RAN and PA. These factors should include working memory and processing speed that have been shown to explain a significant part of the common variation between developmental disorders (Boada et al., 2012; Compton et al., 2012; Landerl et al., 2009; McGrath et al., 2011; Willcutt, Betjemann, et al., 2010; Willcutt, Pennington, et al., 2010; Willcutt et al., 2013). In addition, longitudinal studies following the precursors of comorbidity are important in investigating the primary and secondary effects of these disorders. In future studies on double deficits, longitudinal studies that include the phase before emerging reading skills should be conducted to explore the causality or reciprocity of the precursors of reading and emerging reading skills (see e.g. Castles \& Coltheart, 2004, for a discussion on PA and reading). Finally, intervention studies for RDs derived from different background deficiencies (NSD, PD, DD) should also be developed and studied.

In sum, PA or RAN alone was not sufficient in explaining RD, but when they were measured together, they detected the majority of the RDs in this sample: $90 \%$ of children with RD had a deficit in phonological awareness, rapid automatized naming, or both. PA and RAN were especially associated with RD, not MD or AD. These results strengthen the position of RAN and PA as background skills of reading disabilities also in clinical samples with comorbid math and attention deficit. 


\section{ACKNOWLEDGEMENTS}

This paper is part of the primary author's doctoral dissertation. Financial support for this research was provided for Riikka Heikkilä by National Doctoral Programme of Psychology. The authors want to acknowledge Kenneth Eklund, Tuire Koponen, Kaisa Lohvansuu and two anonymous reviewers for their valuable comments on the manuscript and the Child Research Clinic of the Niilo Mäki Institute for the provition of the data. 


\section{REFERENCES}

Aarnoutse, C., van Leeuwe, J., \& Verhoeven, L. (2005). Early literacy from a longitudinal perspective. Educational Research and Evaluation, 11(3), 253-275.

Achenbach, T. M., \& Rescorla, L. A. (2001). Manual for the ASEBA school-age forms $\mathcal{E}$ profiles. Burlington, VT: University of Vermont, Research Center for Children, Youth, and Families.

Ackerman, P. T., \& Dykman, R. A. (1993). Phonological processes, confrontational naming, and immediate memory in dyslexia. Journal of Learning Disabilities, 26, 597-609.

Ackerman, P. T., Holloway, C. A., Youngdahl, P. L., \& Dykman, R. A. (2001). The double-deficit theory of reading disability does not fit all. Learning Disabilities Research $\mathcal{E}$ Practice, 16, 152-160.

Ahonen, T., Tuovinen, S., \& Leppäsaari, T. (1999). Nopean sarjallisen nimeämisen testi [The test of rapid serial naming]. Jyväskylä, Finland: Niilo Mäki Instituutti \& Haukkarannan koulu.

Arnett, A. B., Pennington, B. F., Willcutt, E., Dmitrieva, J., Byrne, B., Samuelsson, S., \& Olson, R. K. (2012). A cross-lagged model of the development of ADHD inattention symptoms and rapid naming speed. Journal of Abnormal Child Psychology, 40, 1313-1326.

Aro, T., Ahonen, T., Tolvanen, A., Lyytinen, H., \& de Barra, H. T. (1999). Contribution of ADHD characteristics to the academic treatment outcome of children with learning difficulties. Developmental Neuropsychology, 15, 291-305.

Aro, M., \& Wimmer, H. (2003). Learning to read: English in comparison to six more regular orthographies. Applied Psycholinguistics, 26, 619-634.

Bental, B., \& Tirosh, E. (2007). The relationship between attention, executive functions and reading domain abilities in attention deficit hyperactivity disorder and reading disorder: A comparative study. Journal of Child Psychology and Psychiatry, 48, 455-463.

Boada, R., Willcutt, E. G., \& Pennington, B. F. (2012). Understanding the comorbidity between dyslexia and Attention-Deficit/Hyperactivity Disorder. Topics in Language Disorders, 32, 264-284.

Branum-Martin, L., Fletcher, J. M., \& Stuebing, K. K. (2013). Classification and Identification of Reading and Math Disabilities: The Special Case of Comorbidity. Journal of Learning Disabilities, 46, 490-499.

Caravolas, M., Volín, J., \& Hulme, C. (2005). Phoneme awareness is a key component of alphabetic literacy skills in consistent and inconsistent orthographies: Evidence from Czech and English children. Journal of Experimental Child Psychology, 92, 107-139.

Castles, A., \& Coltheart, M. (2004). Is there a causal link from phonological awareness to success in learning to read? Cognition, 91, 77-111.

Compton, D. L., DeFries, J. C., \& Olson, R. K. (2001). Are RAN and phonological deficits additive in children with reading disabilities? Dyslexia, 7, 125-149. 
Compton, D. L., Fuchs, L. S., Fuchs, D., Lambert, W., \& Hamlett, C. (2012). The cognitive and academic profiles of reading and mathematics learning disabilities. Journal of Learning Disabilities, 45, 79-95.

Cornwall, A. (1992). The relationship of phonological awareness, rapid naming, and verbal memory to severe reading and spelling disability. Journal of Learning Disabilities, 8, 532-538.

Cronin, V. (2013). RAN and double-deficit theory. Journal of Learning Disabilities, 46, 182-190.

Czamara, D., Tiesler, C. M. T., Kohlböck, G., Berdel, D., Hoffmann, B., . . Heinrich, J. (2013). Children with ADHD symptoms have a higher risk for reading, spelling and math difficulties in the GINIplus and LISAplus cohort studies. PLoS ONE, 8(5), e63859. doi:10.1371/journal.pone.0063859

De Jong, P. F., \& van der Leij, A. (2003). Developmental changes in the manifestation of a phonological deficit in dyslexic children learning to read a regular orthography. Journal of Educational Psychology, 95, 22-40.

Denckla, M. B., \& Rudel, R. G. (1976). Rapid automatised naming (R.A.N.): Dyslexia differentiated from other learning disabilities. Neuropsychologia, 14, 471-479.

De Smedt, B., \& Boets, B. (2010). Phonological processing and arithmetic fact retrieval: Evidence from developmental dyslexia. Neuropsychologia, 48, 39733981.

DuPaul, G. J., Gormley, M. J., \& Laracy, S. D. (2013). Comorbidity of LD and ADHD: Implications of DSM-5 for assessment and treatment. Journal of Learning Disabilities, 46, 43-51.

Durand, M., Hulme, C., Larkin, R., \& Snowling, M. (2005). The cognitive foundations of reading and arithmetic skills in 7-to 10-year-olds. Journal of Experimental Child Psychology, 91, 113-136.

Elliott, J. G., \& Grigorenko, E. L. (2014). The dyslexia debate (Vol. 14). Cambridge University Press.

Felton, R. H., \& Wood, F. B. (1989). Cognitive deficits in reading disability and attention deficit disorder. Journal of Learning Disabilities, 22, 3-13.

Felton, R. H., Wood, F. B., Brown, I. S., Campbell, S. K., \& Harter, M. R. (1987). Separate verbal memory and naming deficits in attention deficit disorder and reading disability. Brain and Language, 31, 171-184.

Fletcher, J. M. (2005). Predicting math outcomes: Reading predictors and comorbidity. Journal of Learning Disabilities, 38, 308-312.

Fuchs, L. S., Fuchs, D., \& Compton, D. L. (2013). Intervention effects for students with comorbid forms of learning disability: Understanding the needs of nonresponders. Journal of Learning Disabilities, 46, 534-548.

Furnes, B., \& Samuelsson, S. (2010). Predicting reading and spelling difficulties in transparent and opaque orthographies: A comparison between Scandinavian and U.S./Australian children. Dyslexia, 16, 119-142.

Furnes, B., \& Samuelsson, S. (2011). Phonological awareness and rapid automatized naming predicting early development in reading and spelling: Results from a cross-linguistic longitudinal study. Learning and Individual Differences, 21, 85-95.

Geary, D. C. (1993). Mathematical disabilities: Cognitive, neuropsychological, and genetic components. Psychological Bulletin, 114, 345-362. 
Geary, D. C., Hamson, C., \& Hoard, O. (2000). Numerical and arithmetical cognition: A longitudinal study of process and concept deficits in children with learning disability. Journal of Experimental Child Psychology, 77, 236-263.

Georgiou, G., \& Parrila, R. (2013). Rapid naming and reading: A review. In H. L. Swanson, K. L. Harris, \& S. Graham (Eds.), Handbook of learning disabilities (pp. 169-185). Guilford Press.

Georgiou, G. K., Tziraki, N., Manolitsis, G., \& Fella, A. (2013). Is rapid automatized naming related to reading and mathematics for the same reason(s)? A followup study from kindergarten to Grade 1. Journal of Experimental Child Psychology, $115,481-496$.

Germanò, E., Gagliano, A. M. D., \& Curatolo, P. (2010). Comorbidity of ADHD and dyslexia. Developmental Neuropsychology, 35, 475-493.

Gooch, D., Snowling, M., \& Hulme, C. (2011). Time perception, phonological skills and executive function in children with dyslexia and/or ADHD symptoms. Journal of Child Psychology and Psychiatry 52, 195-203.

Hart, S. A., Petrill, S., Thompson, L. A., \& Plomin, R. (2009). The ABCs of math: A genetic analysis of mathematics and its links with reading ability and general cognitive ability. Journal of Educational Psychology, 101, 388-402.

Hecht, S. A., Torgesen, J. K., Wagner, R. K., \& Rashotte, C. A. (2001). The relations between phonological processing abilities and emerging individual differences in mathematical computation skills: A longitudinal study from second to fifth grades. Journal of Experimental Child Psychology, 79, 192-227.

Heikkilä, R., Närhi, V., Aro, M., \& Ahonen, T. (2009). Rapid automatized naming and learning disabilities: Does RAN have a specific connection to reading or not? Child Neuropsychology, 15, 343-358.

Hynd, G. W., Lorys, A. R., Semrud-Clikeman, M., Nieves, N., Huettner, M. I. S., \& Lahey, B. B. (1991). Attention deficit disorder without hyperactivity: A distinct behavioral and neurocognitive syndrome. Journal of Child Neurology, 6, 37-43.

Häyrinen, T., Serenius-Sirve, S., \& Korkman, M. (1999). Lukilasse [Lukilasse-test battery for screening reading, spelling, and arithmetics]. Helsinki, Finland: Psykologien Kustannus.

Kairaluoma, L., Torppa, M., Westerholm, J., Ahonen, T., \& Aro, M. (2013). The nature of and factors related to reading difficulties among adolescents in a transparent orthography. Scientific Studies of Reading, 17, 315-332.

Katzir, T., Kim, Y., Wolf, M., Kennedy, B., Lovett, M., \& Morris, R. (2006). The relationship of spelling recognition, RAN, and phonological awareness to reading skills in older poor readers and younger reading-matched controls. Reading and Writing, 19, 845-872.

Kirby, J. R., Georgiou, G. K., Martinussen, R., \& Parrila, R. (2010). Naming speed and reading: From prediction to instruction. Reading Research Quarterly, 45, 341-362.

Koponen, T., Aunola, K., Ahonen, T., \& Nurmi, J.-E. (2007). Cognitive predictors of single-digit and procedural calculation skills and their covariation with reading skill. Journal of Experimental Child Psychology, 97, 220-241.

Koponen, T., Salmi, P., Eklund, K., \& Aro, T. (2013). Counting and RAN: Predictors of arithmetic calculation and reading fluency. Journal of Educational Psychology, $105,162-175$. 
Korkman, M., Kirk, U., \& Kemp, S. L. (1997). NEPSY: Lasten neuropsykologinen tutkimus [The NEPSY: The Finnish developmental neuropsychological evaluation]. Helsinki, Finland: Psykologien kustannus Oy.

Kovas, Y., Haworth, C. M. A., Harlaar, N., Petrill, S. A., Dale, P. S., \& Plomin, R. (2007). Overlap and specificity of genetic and environmental influences on mathematics and reading disability in 10 - year - old twins. Journal of Child Psychology and Psychiatry, 48, 914-922.

Krajewski, K., \& Schneider, W. (2009). Exploring the impact of phonological awareness, visual-spatial working memory, and preschool quantity-number competencies on mathematics achievement in elementary school: Findings from a 3-year longitudinal study. Journal of Experimental Child Psychology, 103, 516-531.

Landerl, K., Bevan, A., \& Butterworth, B. (2004). Developmental dyscalculia and basic numerical capacities: A study of 8-9-year-old students. Cognition, 93, 99-125.

Landerl, K., Fussenegger, B., Moll, K., \& Willburger, E. (2009). Dyslexia and dyscalculia: Two learning disorders with different cognitive profiles. Journal of Experimental Child Psychology, 103, 309-324.

Landerl, K., \& Moll, K. (2010). Comorbidity of learning disorders: Prevalence and familial transmission. Journal of Child Psychology and Psychiatry and Allied Disciplines, 51, 287-294.

Landerl, K., \& Wimmer, H. (2008). Development of word reading fluency and spelling in a consistent orthography: An 8-year follow-up. Journal of Educational Psychology, 100, 150-161.

Landerl, K., Wimmer, H., \& Frith, U. (1997). The impact of orthographic consistency on dyslexia: A German-English comparison. Cognition, 63, 315-334.

Lyytinen, H., Leinonen, S., Nikula, M., Aro, M., \& Leiwo, M. (1995). In search of the core features of dyslexia: Observations concerning dyslexia in the highly orthographically regular Finnish language. In V. W. Berninger (Ed.), The varieties of orthographic knowledge. II: Relationships to phonology, reading, and writing (pp. 77-204). Dordrecht, the Netherlands: Kluwer.

Manis, F. R., Doi, L. M., \& Bhadha, B. (2000). Naming speed, phonological awareness, and orthographic knowledge in second graders. Journal of Learning Disabilities, $33,325-333$.

Mazzocco, M. M. M., \& Grimm, K. J. (2013). Growth in rapid automatized naming from Grades $\mathrm{K}$ to 8 in children with math or reading disabilities. Journal of Learning Disabilities, 46, 517-533.

McBride-Chang, C., \& Manis, F. R. (1996). Structural invariance in the associations of naming speed, phonological awareness, and verbal reasoning in good and poor readers: A test of the double-deficit hypothesis. Reading and Writing: An Interdisciplinary Journal, 8, 323-339.

McGee, R., Brodeur, D., Symons, D., Andrade, B., \& Fahie, C. (2004). Time perception: Does it distinguish ADHD and RD children in a clinical sample? Journal of Abnormal Child Psychology, 32, 481-490.

McGrath, L. M., Pennington, B. F., Shanahan, M. A., Santerre-Lemmon, L. E., Barnard, H. D., Willcutt, E. G., . . . \& Olson, R. K. (2011). A multiple deficit 
model of reading disability and attention-deficit/hyperactivity disorder: Searching for shared cognitive deficits. Journal of Child Psychology and Psychiatry, 52, 547-557.

Meyer, M. S., Wood, F. B., Hart, L. A., \& Felton, R. H. (1998). Selective predictive value of rapid automatized naming in poor readers. Journal of Learning Disabilities, 31, 106-117.

Miranda, A., Presentación, M. J., Siegenthaler, R., Colomer, C., \& Pinto, V. (2011). Comorbidity between attention deficit hyperactivity disorder and reading disabilities: Implications for assessment and treatment. Advances in Learning and Behavioral Disabilities, 24, 171-211.

Moll, K., Göbel, S. M., Gooch, D., Landerl, K., \& Snowling, M. J. (2014). Cognitive Risk Factors for Specific Learning Disorder: Processing Speed, Temporal Processing, and Working Memory. Journal of Learning Disabilities. Advance online publication.

Moll, K., Göbel, S. M., \& Snowling, M. J. (2014). Basic number processing in children with specific learning disorders: Comorbidity of reading and mathematics disorders. Child Neuropsychology. Advance online publication. doi:10.1080/09297049.2014.899570

Moll, K., Ramus, F., Bartling, J., Bruder, J., Kunze, S., Neuhoff, N., . . Landerl, K. (2014). Cognitive mechanisms underlying reading and spelling development in five European orthographies. Learning and Instruction, 29, 65-77.

Murphy, M. M., Mazzocco, M. M., Hanich, L. B., \& Early, M. C. (2007). Cognitive characteristics of children with mathematics learning disability (MLD) vary as a function of the cutoff criterion used to define MLD. Journal of Learning Disabilities, 40, 458-478.

Niilo Mäki Institute. (2004). Neuropsychological and achievement tests: Local normative data for Niilo Mäki Institute test battery. Jyväskylä, Finland: Author.

Norton, E. S., Black, J. M., Stanley, L. M., Tanaka, H., Gabrieli, J. D., Sawyer, C., \& Hoeft, F. (2014). Functional neuroanatomical evidence for the double-deficit hypothesis of developmental dyslexia. Neuropsychologia, 61, 235-246.

Norton, E. S., \& Wolf, M. (2012). Rapid automatized naming (RAN) and reading fluency: Implications for understanding and treatment of reading disabilities. Annual Review of Psychology, 63, 427-452.

Närhi, V., \& Ahonen, T. (1995). Reading disability with or without attention deficit hyperactivity disorder: Do attentional problems make a difference? Developmental Neuropsychology, 11, 337-349.

Papadopoulos, T. C., Georgiou, G., \& Kendeou, P. (2009). Investigating the doubledeficit hypothesis in Greek: Findings from a longitudinal study. Journal of Learning Disabilities, 42, 528-547.

Pennala, R., Eklund, K., Hämäläinen, J., Richardson, U., Martin, M., Leiwo, M., . . . Lyytinen, H. (2010). Perception of phonemic length and its relation to reading and spelling skills in children with family risk for dyslexia in the first three grades of school. Journal of Speech, Language, and Hearing Research, 53, 710-724.

Pennington, B. F. (2006). From single to multiple deficit models of developmental disorders. Cognition, 101, 385-413. 
Pennington, B. F., Cardoso-Martins, C., Green, P. A., \& Lefly, D. L. (2001). Comparing the phonological and double deficit hypotheses for developmental dyslexia. Reading and Writing: An Interdisciplinary Journal, 14, 707-755.

Pennington, B. F., Santerre-Lemmon, L., Rosenberg, J., MacDonald, B., Boada, R., Friend, A., . . Olson, R. K. (2012). Individual prediction of dyslexia by single versus multiple deficit models. Journal of Abnormal Psychology, 121, 212-224.

Puolakanaho, A., Ahonen, T., Aro, M., Eklund, K., Leppänen, P. H. T., Poikkeus, A.M., ... Lyytinen, H. (2008). Developmental links of very early phonological and language skills to second grade reading outcomes: Strong to accuracy but only minor to fluency. Journal of Learning Disabilities, 41, 353-370.

Puolakanaho, A., Poikkeus, A., Ahonen, T., Tolvanen, A., \& Lyytinen, H. (2004). Emerging phonological awareness differentiates children with and without familial risk for dyslexia after controlling for general language skills. Annals of Dyslexia, 54, 221-243.

Purvis, K. L., \& Tannock, R. (2000). Phonological processing, not inhibitory control, differentiates ADHD and reading disability. Journal of the American Academy of Child \& Adolescent Psychiatry, 39, 485-494.

Raberger, T., \& Wimmer, H. (2003). On the automaticity/cerebellar deficit hypothesis of dyslexia: Balancing and continuous rapid naming in dyslexic and ADHD children. Neuropsychologia, 41, 1493-1497.

Rucklidge, J. J., \& Tannock, R. (2002). Neuropsychological profiles of adolescents with ADHD: Effects of reading difficulties and gender. Journal of Clinical Psychology and Psychiatry, 43, 988-1003.

Räsänen, P. (2004). RMAT - Laskutaidon testi 9-12 -vuotiaille [RMAT - a test for mathematical achievement for ages 9 to 12]. Finland, Jyväskylä: Niilo Mäki Institute.

Schatschneider, C., Carlson, C. D., Francis, D. J., Foorman, B. R., \& Fletcher, J. M. (2002). Relationship of rapid automatized naming and phonological awareness in early reading development: Implications for double-deficit hypothesis. Journal of Learning Disabilities, 35, 245-256.

Semrud-Clikeman, M., Biederman, J., Sprich-Buckminster, S., Lehman, B. K., Faraone, S. V., \& Norman, D. (1992). Comorbidity between ADHD and learning disability: A review and report in a clinically referred sample. Journal of the American Academy of Child and Adolescent Psychiatry, 31, 439-448.

Semrud-Clikeman, M., Guy, K., Griffin, J. D., \& Hynd, G. W. (2000). Rapid naming deficits in children and adolescents with reading disabilities and attention deficit hyperactivity disorder. Brain \& Language, 74, 70-83.

Sexton, C. C., Gelhorn, H. L., Bell, J. A., \& Classi, P. M. (2012). The co-occurrence of reading disorder and ADHD: Epidemiology, treatment, psychosocial impact, and economic burden. Journal of Learning Disabilities, 45, 538-564.

Seymour, P. H. K., Aro, M., \& Erskine, J. M. (2003). Foundation literacy acquisition in European orthographies. British Journal of Psychology, 94, 143-174.

Simmons, F. R., \& Singleton, C. (2009). The mathematical strengths and weaknesses of children with dyslexia. Journal of Research in Special Educational Needs, 9, 154163. 
Stanovich, K. E., \& Siegel, L. S. (1994). Phenotypic performance profile of children with reading disabilities: A regression-based test of the phonological-core variable-difference model. Journal of Educational Psychology, 86, 24-53.

Steacy, L. M., Kirby, J. R., Parrila, R., \& Compton, D. L. (2014). Classification of Double Deficit Groups Across Time: An Analysis of Group Stability From Kindergarten to Second Grade. Scientific Studies of Reading, 18, 255-273.

Sunseth, K., \& Bowers, P. G. (2002). Rapid naming and phonemic awareness: Contributions to reading, spelling, and orthographic knowledge. Scientific Studies of Reading, 6, 401-429.

Tannock, R., Martinussen, R., \& Frijters, J. (2000). Naming speed performance and stimulant effects indicate effortful, semantic processing deficits in attentiondeficit/hyperactivity disorder. Journal of Abnormal Child Psychology, 28, 237-252.

Thomson, J. B., Chenault, B., Abbot, R. D., Raskind, W. H., Richards, T., Aylward, E., . Berninger, V. W. (2005). Converging evidence for attentional influences on the orthographic word form in child dyslexics. Journal of Neurolinguistics, 18, 93-126.

Torppa, M., Georgiou, G., Salmi, P., Eklund, E., \& Lyytinen, H. (2012). Examining the double-deficit hypothesis in an orthographically consistent language. Scientific Studies of Reading, 16, 287-315.

Torppa, M., Lyytinen, P., Erskine, J., Eklund, K., \& Lyytinen, H. (2010). Language development, literacy skills, and predictive connections to reading in Finnish children with and without familial risk for dyslexia. Journal of Learning Disabilities 43, 308-321.

Torppa, M., Parrila, R., Niemi, P., Lerkkanen, M.-K., Poikkeus, A.-M., \& Nurmi, J.-E. (2013). The double-deficit hypothesis in the transparent Finnish orthography: A longitudinal study from kindergarten to Grade 2. Reading and Writing, 26, 13531380.

Trenta, M., Benassi, M., Di Filippo, G., Pontillo, M., \& Zoccolotti, P. (2013). Developmental dyslexia in a regular orthography: can the reading profile be reduced to strategic control? Cognitive Neuropsychology, 30, 147-171.

Vaessen, A., Bertrand, D., Tóth, D., Csépe, V., Faísca, L., Reis, A., \& Blomert, L. (2010). Cognitive development of fluent word reading does not qualitatively differ between transparent and opaque orthographies. Journal of Educational Psychology, 102, 827-842.

Vaessen, A., Gerretsen, P., \& Blomert, L. (2009). Naming speed problems do not reflect a second independent core deficit in dyslexia: Double-deficits explored. Journal of Experimental Child Psychology, 103, 202-221.

van Bergen, E., de Jong, P. F., Maassen, B., \& van der Leij, A. (2014). The effect of parents' literacy skills and children's preliteracy skills on the risk of dyslexia. Journal of Abnormal Child Psychology, 42, 1187-1200.

van der Sluis, S., de Jong, P. F., \& Leij, A. V. D. (2004). Inhibition and shifting in children with learning deficits in arithmetic and reading. Journal of Experimental Child Psychology, 87, 239-266.

van der Sluis, S., de Jong, P. F., \& van der Leij, A. (2007). Executive functioning in children, and its relations with reasoning, reading, and arithmetic. Intelligence, $35,427-449$. 
Vellutino, F. R., Fletcher, J. M., Snowling, M. J., \& Scanlon, D. M. (2004). Specific reading disability (dyslexia). What have we learned in the past four decades? Journal of Child Psychology and Psychiatry, 45, 2-40.

Vukovic, R. K., \& Siegel, L. (2006). The double-deficit hypothesis: A comprehensive analysis of the evidence. Journal of Learning Disabilities, 39, 25-47.

Waber, D. P., Forbes, P. W., Wolff, P. H., \& Weiler, M. D. (2004). Neurodevelopmental characteristics of children with learning impairments classified according to the double-deficit hypothesis. Journal of Learning Disabilities, 37, 451-461.

Waber, D. P., Weiler, M. D., Forbes, P. W., Bernstein, J. H., Bellinger, D. C., \& Rappaport, L. (2003). Neurobehavioral factors associated with referral for learning problems in a community sample: Evidence for an adaptational model for learning disorders. Journal of Learning Disabilities, 36, 467-483.

Wechsler, D. (1974). Manual for the Wechsler Intelligence Scale for Children-Revised. San Antonio, TX: Psychological.

Wechsler, D. (1991). Manual for the Wechsler Intelligence Scale for Children-Third Edition. San Antonio, TX: Psychological.

Willburger, E., Fussenegger, B., Moll, K., Wood, G., \& Landerl, K. (2008). Naming speed in dyslexia and dyscalculia. Learning and Individual Differences, 18, 224236.

Willcutt, E. G., Betjemann, R. S., McGrath, L. M., Chhabildas, N. A., Olson, R. K., DeFries, J. C., \& Pennington, B. F. (2010). Etiology and neuropsychology of comorbidity between RD and ADHD: The case for multiple-deficit models. Cortex, 46, 1345-1361.

Willcutt, E. G., \& Pennington, B. F. (2000). Comorbidity of reading disability and attention-deficit/hyperactivity disorder differences by gender and subtype. Journal of Learning Disabilities, 33, 179-191.

Willcutt, E. G., Pennington, B. F., Boada, R., Ogline, J. S., Tunick, R. A., Chhabildas, N. A., \& Olson, R. K. (2001). A comparison of the cognitive deficits in reading disability and attention-deficit/hyperactivity disorder. Journal of Abnormal Psychology, 110, 157-172.

Willcutt, E.G., Pennington, B.F., Duncan, L., Smith, S.D., Keenan, J. M., Wadsworth, S., . . Olson, R. K. (2010). Understanding the complex etiologies of developmental disorders: Behavioral and molecular genetic approaches. Journal of Developmental \& Behavioral Pediatrics, 31, 533-544.

Willcutt, E. G., Petrill, S. A., Wu, S., Boada, R., DeFries, J. C., Olson, R. K., \& Pennington, B. F. (2013). Comorbidity between reading disability and math disability concurrent psychopathology, functional impairment, and neuropsychological functioning. Journal of Learning Disabilities, 46, 500-516.

Wimmer, H., Mayringer, H., \& Landerl, K. (2000). The double-deficit hypothesis and difficulties in learning to read a regular orthography. Journal of Educational Psychology, 92, 668-680.

Wise, J. C., Pae, H. K., Wolfe, C. B., Sevcik, R. A., Morris, R. D., Lovett, M., \& Wolf, M. (2008). Phonological awareness and rapid naming skills of children with reading disabilities and children with reading disabilities who are at risk for mathematics difficulties. Learning Disabilities Research \& Practice, 23, 125-136. 
Wolf, M., \& Bowers, P. G. (1999). The double-deficit hypothesis for the developmental dyslexias. Journal of Educational Psychology, 91, 415-438.

Wolf, M., \& Bowers, P. (2000). Naming-speed processes and developmental reading disabilities: An introduction to the special issue on the double-deficit hypothesis. Journal of Learning Disabilities, 33, 322-324.

Wolf, M., Bowers, P. G., \& Biddle, K. (2000). Naming-speed processes, timing, and reading A conceptual review. Journal of Learning Disabilities, 33, 387-407.

Ziegler, J. C., Bertrand, D., Tóth, D., Csépe, V., Reis, A., Faísca, L., . . Blomert, L. (2010). Orthographic depth and its impact on universal predictors of reading: a cross-language investigation. Psychological Science, 21, 551-559. 
III

\title{
DOES TRAINING IN SYLLABLE RECOGNITION IMPROVE READING SPEED? A COMPUTER-BASED TRIAL WITH POOR READERS FROM SECOND AND THIRD GRADE
}

\author{
by \\ Riikka Heikkilä, Mikko Aro, Vesa Närhi, Jari Westerholm, \& Timo Ahonen, 2013 \\ Scientific Studies of Reading, 17, 398-414
}

Reproduced with kind permission by Taylor \& Francis Group. 


\title{
Does Training in Syllable Recognition Improve Reading Speed? A Computer-Based Trial With Poor Readers From Second and Third Grade
}

\author{
Riikka Heikkilä \\ University of Jyväskylä and Niilo Mäki Institute \\ Mikko Aro \\ University of Jyväskylä \\ Vesa Närhi \\ Niilo Mäki Institute and The Finnish Association on Intellectual \\ and Developmental Disabilities \\ Jari Westerholm \\ Niilo Mäki Institute \\ Timo Ahonen \\ University of Jyväskylä
}

\begin{abstract}
Repeated reading of infrequent syllables has been shown to increase reading speed at the word level in a transparent orthography. This study confirms these results with a computer-based training method and extends them by comparing the training effects of short syllables and long frequent and infrequent syllables, controlling for rapid automatized naming. Our results, based on a sample of 150 poor readers of Finnish, showed clear gains in reading speed regarding all trained syllables, but a transfer effect to the word level was evident only in the case of long infrequent syllables. Rapid automatized naming was associated with initial reading speed, but not with the training effect.
\end{abstract}

Reading fluency, usually defined as accurate reading with adequate speed and prosody (Kuhn \& Stahl, 2003; National Institute of Child Health and Human Development, 2000), is a prerequisite and a correlate to reading comprehension (Klauda \& Guthrie, 2008; Therrien, 2004) as the automatization of reading processes releases cognitive resources for higher level processing (LaBerge \& Samuels, 1974; Perfetti, 1985). This automatization process is gradual and developmental, rather

Correspondence should be sent to Riikka Heikkilä, Niilo Mäki Institute, University of Jyväskylä, P.O. Box 35, Jyväskylä, 40014 Finland. E-mail: riikka.heikkila@nmi.fi 
than being an on/off skill, and is a result of lexical and sublexical processes that lead to wellspecified representations of orthographic items (Kame'enui \& Simmons, 2001; Share, 1995). However, children with reading disabilities seem to have difficulties in attaining these skills. Fluency problems have proven to be very persistent (de Jong \& van der Leij, 2003; Landerl \& Wimmer, 2008) and rather resistant to intervention, at least in regard to attaining a normal reading level (Meyer \& Felton, 1999; Thaler, Ebner, Wimmer, \& Landerl, 2004). However, even limited progress in reading speed can have an effect on both reading accuracy and comprehension (Breznitz, 2006). Therefore, in this study, we focus on the speed component of reading fluency and aim to intervene in dysfluent reading in a highly transparent language, Finnish.

A growing body of research is now exposing slight differences in reading development in opaque and transparent languages. In opaque languages like English, the development of accurate reading takes remarkably more time than in more regular orthographies (Seymour, Aro, \& Erskine, 2003). Therefore, in transparent orthographies (like German, Dutch, Spanish, Italian, and Finnish), reading problems manifest as slow and laborious reading rather than inaccurate reading (Escribano, 2007; Holopainen, Ahonen, \& Lyytinen, 2001; Wimmer, 1993; Yap \& van der Leij, 1993; Zoccolotti et al., 1999). In regular orthographies with almost perfect transparency between letters and phonemes in both directions (e.g. Finnish, Italian), it is possible for readers to attend to very small units and to adhere to a serial letter-by-letter reading strategy (Frost, Katz, \& Bentin, 1987; Pagliuca \& Monaghan, 2010; Ziegler \& Goswami, 2005). It seems, however, that using sublexical units larger than letters would benefit the reader in transparent orthographies even when it is possible to construct the word from single letters (Pagliuca \& Monaghan, 2010; Paulesu, 2006). Therefore, intervention methods that help the reader to disentangle himself from a reading strategy based on an assembly of small units are needed to support reading fluency. Gains in fluency would promote reading comprehension (Breznitz, 2006) but also reinforce motivation toward reading, which has been shown to increase time spent reading (Leinonen et al., 2001).

The recognition units most commonly addressed in fluency intervention have been words, but training in sublexical units like consonant clusters (Hintikka, Landerl, Aro, \& Lyytinen, 2008; Marinus, de Jong, \& van der Leij, 2012), syllables (Huemer, Aro, Landerl, \& Lyytinen, 2010; Tressoldi, Vio, \& Iozzino, 2007), and morphemes (Burani, Marcolini, De Luca, \& Zoccolotti, 2008) has also been shown to promote reading skill in transparent languages. Which units are most beneficial may vary, depending on the features of the language (Duncan, Colé, Seymour, \& Magnan, 2006). The reason why training with whole words is unlikely to be effective in Finnish is inherent to the agglutinative nature of Finnish inflectional morphology, which results in numerous word forms (based on case and number; Karlsson, 2008) and increases in word length. As most of the effects of training based on repetition of learned material are known to be item specific (Berends \& Reitsma, 2006; Lemoine, Levy, \& Hutchinson, 1993; Marinus et al., 2012; Thaler et al., 2004), training with words in Finnish would require practicing all common word forms, which is not possible. In Finnish, many of the previously mentioned sublexical units are also problematic as targets of practice. First, consonant clusters are uncommon and are rarely found in word-initial (and never in word-final) position. Second, Finnish morphology is very complex, and the same morpheme can be marked in several ways, depending on the context (for a more detailed description of the Finnish language, see Aro, 2006; Leinonen et al., 2001; Niemi, Laine, \& Tuominen, 1994). Therefore, as Huemer and colleagues (2010) have summarized, the syllable is potentially a more useful perceptual unit in Finnish for various reasons, most obviously 
because of the polysyllabic nature and the clear syllable structure of the language. Indeed, syllables seem to be effective units in promoting reading speed in languages with a clear syllable structure (Finnish: Huemer et al., 2010; Italian: Tressoldi et al., 2007; and Dutch: Wentink, van Bon, \& Schreuder, 1997).

The role of syllables in reading development (and, accordingly, in training) is also supported by some theoretical models. With its specific focus on reading of multisyllabic items, the multiple-trace memory model (Ans, Carbonnel, \& Valdois, 1998) postulates that polysyllabic low-frequency words and nonwords that cannot be recognized as a whole unit are analyzed and broken down into syllables. It is also hypothesized that immediately after graphophonemic processing has become automatic, children turn to graphosyllabic processing: They begin to extract units that are larger than phonemes (Duncan et al., 2006; Ecalle \& Magnan, 2007). This is in line with the idea of the self-teaching mechanism in decoding (Share, 1995). It enables the reader to learn item-specific associations between print and sound during independent reading practice. These learned associations are thought to bypass serial sublexical processing and enhance the use of orthographical representations in reading.

Turning to intervention methods, the most common used for fluency training is repeated reading, a method based on repetition of reading material, usually words or texts (for reviews, see Chard, Vaughn, \& Tyler, 2002; Kuhn \& Stahl, 2003; Therrien, 2004). Repeated reading can be used in an assisted tutor-learner setting, as an independent practice according to traditional methods, or in computer-assisted methods (Huemer, 2009). Because an increase in fluency seems to require multiple repetitions (Chard et al., 2002; Lemoine et al., 1993), repeated reading methods implemented in computer environments offer an appealing and cost-effective alternative to one-on-one tutoring. Computers are available in most cases, providing a standard presentation of tasks, sufficient repetitions with immediate feedback, and possibly more motivating training methods than traditional repeated reading. In addition, computer-assisted methods have proven to be beneficial for fluency training (Huemer, 2009; Huemer, Landerl, Aro, \& Lyytinen, 2008; Irausquin, Drent, \& Verhoeven, 2005) and for producing lasting effects in reading by means of syllable-based training (Ecalle, Magnan, \& Calmus, 2009). To overcome the problem of monitoring reading, this study uses a computer-assisted method of repeated recognition of targeted units (syllables).

The first study that combined direct syllable training with repeated reading practice (Huemer et al., 2010) showed that gains in syllable reading speed were transferred to pseudowords containing practiced syllables. That study explored the effect of syllable training with infrequent syllables, in which the training effect was expected to be greater, due to less exposure to the material prior to training. Our study aimed to determine if those results could also be replicated with frequent syllables, which are more essential in everyday reading (in the sense that more frequent syllables potentially have a greater direct effect on general reading, as they compose a larger portion of the text than the same amount of infrequent syllables). In our study, we included syllables with no semantic meaning that vary in frequency and length.

It is known that frequent words are read more accurately and faster than infrequent words (Berends \& Reitsma, 2006). However, the results regarding the effects of syllable frequency are slightly more heterogeneous, depending on the reading task (lexical decision or naming), on the item used in reading (word or nonword), or on the language under investigation. Especially it depends on the consistency of the stress assignment in the language (e.g., Conrad, Stenneken, \& Jacobs, 2006). To our knowledge, the effect of syllable frequency on reading single syllables has 
not been studied before. In this study, we compared effects of training related to frequent and infrequent long (four-letter) syllables. Because the lexicality effect is not present in syllable reading, we expected the initial reading speed of frequent syllables to be faster than that of infrequent syllables, due to greater prior exposure but also based on the results yielded by pseudoword reading, in which a facilitating effect of syllable frequency has been found (Carreiras \& Perea, 2004). At the same time, however, due to less prior exposure to infrequent syllables, we expected greater gains in reading speed of infrequent than frequent syllables after repeated reading. Because the length effect seems to be strong in poor readers and appears to decrease with practice (Maloney, Risko, O’Malley, \& Besner, 2009), we assumed that the training effect should be relatively greater for longer syllables, indicating a shift from letter-by-letter processing to recognition of a syllable as a unit. As several studies have shown the effects of training with single items to be item specific (e.g., Berends \& Reitsma, 2006; Thaler et al., 2004), we expected generalization only with materials containing practiced syllables, particularly pseudowords containing practiced syllables, following the results by Huemer et al. (2010).

Finally, a number of factors other than method and content presumably affect the effectiveness of training. For instance, various studies have indicated that children with naming speed deficits show less of a response to reading instruction (Berninger et al., 2002; Stage, Abbott, Jenkins, \& Berninger, 2003) and benefit less from repeated reading than children without naming speed deficits (Bowers, 1993; Levy, Bourassa, \& Horn, 1999). However, the response to fluency training has not always been merely affected by slow naming speed (Levy, Abello, \& Lysynchuk, 1997), particularly after the initial reading level has been controlled for (Berends \& Reitsma, 2006). As we acknowledge the strong connection between rapid automatized naming (RAN) and reading fluency (for the most recent reviews, see Kirby, Georgiou, Martinussen, \& Parrila, 2010; Norton \& Wolf, 2012), we expected that RAN would be associated with initial reading speed, if not with the effects of training.

In summary, in this study we explored if syllable reading speed can be improved through repetitive recognition tasks. Further, we examined if the improvement is dependent on the type of practiced items (length or frequency of the syllable) and also if the gains acquired in syllable training are item specific but still transferrable to the word level. Finally, we analyzed if individual variation in RAN and initial reading speed interact with the training effect.

\section{METHODS}

\section{Participants}

The participants were poor readers attending second and third grade, selected from 81 classrooms across Finland. An e-mail was sent to second- and third-grade special and general education teachers registered in a nationwide Internet service that provides information on learning difficulties (http://www.lukimat.fi). The teachers were instructed to nominate pupils who are receiving part-time special education due to reading problems. Parents were informed about the purpose and implementation of the study. All volunteering children with parental permission $(n=$ $265)$ were allowed to participate in the training under the guidance of their teachers $(n=93)$. The children were randomly divided into training and control groups of equal sizes. After the training period and a posttraining test, children with incomplete assessment or training data $(n=72)$, 
multiple deficits in learning or cognition (i.e., a status of full-time special education or reported neurological problems; $n=33$ ), or whose mother tongue was not Finnish $(n=1)$ were excluded. To further ensure the reliability of the reading speed assessment, children with very low reading accuracy ( $2 S D$ below the mean of the sample, $n=9$ ) were excluded. All included participants followed the normal curriculum.

The final sample of participants consisted of 150 children: 96 second graders and 54 third graders. The mean age was 9 years 2 months ( $S D=6$ months), and 59\% of the participants were boys. According to the teachers' reports, reading speed was the main problem for $65 \%$ of the participants, and $70 \%$ had no other learning problems than reading. To provide additional information on the reading level of children included in the study, we compared the reading performance of our sample with representative data of poor and typical readers in Finnish (Jyväskylä Longitudinal Study of Dyslexia [JLD], reported in Torppa, Lyytinen, Erskine, Eklund, \& Lyytinen, 2010). The mean of reading speed was measured on the basis of text reading. The word reading speed of this sample was $1.8 S D$ below the mean of the typical readers in JLD data (for both second and third graders). This was highly comparable to the children with dyslexia in the JLD sample, whose word reading speed was $1.9 \mathrm{SD}$ below the normative mean for second graders and 1.7 SD for third graders. The range for reading speed was also comparable to the JLD dyslexic sample. The fastest readers in this sample were close to the average of typical readers in the JLD sample.

During the training sessions, one group of children practiced a blend of two-letter syllables (Group-2L; $n=48$ ), another group practiced four-letter frequent syllables (Group-4LF; $n=30$ ), and yet another group rehearsed four-letter infrequent syllables (Group-4LI; $n=37$ ), all selected for the purposes of this study according to their frequency and structure. The two-letter syllables were matched with the four-letter frequent syllables according to their frequency, and the fourletter frequent syllables with the four-letter infrequent syllables according to their structure (see Table 3). The control group $(n=35)$ practiced math tasks that did not require reading skills. Due to some attrition between the pre- and the posttraining assessments, the resulting group sizes were uneven. However, the groups did not differ in age, naming speed, reading speed, or gender distribution (see Table 1 and the Pretraining Measurements section), nor in reading errors (Table 2).

Our study was conducted in schools over a 4-week period. The study consisted of a pretraining assessment, the training itself, and a posttraining assessment conducted by teachers as instructed by the authors. The pre- and posttraining tasks, together with detailed instructions for performing the assessment and using the training program, were sent to the teachers prior to the study. This package also included forms to aid teachers and parents in providing background information on the children, as well as a letter with information for the parents. Teachers were also given a contact number to call for support and guidance on the procedures.

\section{Assessment Procedure}

All of the assessments were carried out individually by teachers. Teachers were instructed to present the tasks according to printed instructions and not to give any feedback to students during assessment; all tasks were printed on paper. The students were instructed to read the material aloud as quickly and accurately as possible. The completion time for the text or list was used as 
TABLE 1

Descriptive Statistics and Reading and Naming Times (Means and Standard Deviations) Showing Results From Pre- and Posttraining Tests by Groups

\begin{tabular}{|c|c|c|c|c|c|c|c|c|}
\hline \multirow[b]{2}{*}{ Variable } & \multicolumn{2}{|c|}{ Group $-2 L(\mathrm{n}=48)$} & \multicolumn{2}{|c|}{ Group $-4 L F(\mathrm{n}=30)$} & \multicolumn{2}{|c|}{ Group- $4 L I(\mathrm{n}=37)$} & \multicolumn{2}{|c|}{ Control Group $(\mathrm{n}=35)$} \\
\hline & $\begin{array}{c}\text { Pre } \\
M(S D)\end{array}$ & $\begin{array}{c}\text { Post } \\
M(S D)\end{array}$ & $\begin{array}{c}\text { Pre } \\
M(S D)\end{array}$ & $\begin{array}{c}\text { Post } \\
M(S D)\end{array}$ & $\begin{array}{c}\text { Pre } \\
M(S D)\end{array}$ & $\begin{array}{c}\text { Post } \\
M(S D)\end{array}$ & $\begin{array}{c}\text { Pre } \\
M(S D)\end{array}$ & $\begin{array}{c}\text { Post } \\
M(S D)\end{array}$ \\
\hline Male (\%) & 60.4 & & 66.7 & & 54.1 & & 54.3 & \\
\hline Age (in years) & $9.09(0.69)$ & & $9.24(0.64)$ & & $9.12(0.66)$ & & $9.38(0.75)$ & \\
\hline RAN (letters) & $39.1(8.7)$ & & $37.3(9.1)$ & & $37.7(8.4)$ & & $37.1(8.1)$ & \\
\hline \multicolumn{9}{|c|}{ Reading times (sec/item) } \\
\hline 2L-Syl & $0.97(0.24)$ & $0.81(0.18)$ & $0.90(0.19)$ & $0.78(0.17)$ & $0.96(0.22)$ & $0.86(0.18)$ & $0.90(0.22)$ & $0.83(0.23)$ \\
\hline 4LF-Syl & $1.45(0.46)$ & $1.27(0.36)$ & $1.29(0.41)$ & $1.02(0.34)$ & $1.39(0.45)$ & $1.23(0.41)$ & $1.30(0.43)$ & $1.18(0.42)$ \\
\hline 4LI-Syl & $1.63(0.58)$ & $1.43(0.45)$ & $1.48(0.51)$ & $1.26(0.41)$ & $1.56(0.57)$ & $1.14(0.46)$ & $1.51(0.53)$ & $1.32(0.51)$ \\
\hline 2L-Psw & $1.97(0.63)$ & $1.81(0.58)$ & $1.71(0.53)$ & $1.58(0.54)$ & $1.85(0.67)$ & $1.80(0.66)$ & $1.74(0.57)$ & $1.66(0.58)$ \\
\hline 4LF-Psw & $2.34(0.74)$ & $2.23(0.71)$ & $2.18(0.70)$ & $1.97(0.64)$ & $2.26(0.80)$ & $2.18(0.82)$ & $2.15(0.74)$ & $2.04(0.69)$ \\
\hline 4LI-Psw & $2.58(0.80)$ & $2.34(0.75)$ & $2.34(0.83)$ & $2.22(0.77)$ & $2.46(0.95)$ & $2.16(0.87)$ & $2.27(0.82)$ & $2.14(0.75)$ \\
\hline Text (sec/word) & $2.06(0.92)$ & $1.96(0.85)$ & $1.83(0.95)$ & $1.60(0.71)$ & $2.01(0.89)$ & $1.82(0.78)$ & $1.82(0.76)$ & $1.71(0.74)$ \\
\hline (sec/syllable) & $0.71(0.32)$ & $0.68(0.29)$ & $0.63(0.33)$ & $0.56(0.25)$ & $0.69(0.31)$ & $0.63(0.27)$ & $0.71(0.32)$ & $0.60(0.26)$ \\
\hline
\end{tabular}

Note. Group-2L practiced two-letter syllables (2L-Syl), Group-4LF practiced four-letter frequent syllables (4LFSyl), and Group-4LI practiced four-letter infrequent syllables (4LI-Syl). Psw = pseudowords; 2L-Psw are pseudowords, including trained two-letter syllables, and so on; RAN = rapid automatized naming.

TABLE 2

Reading Accuracy Percentage (Means and Standard Deviations) Showing Results From Pre- and Posttraining Tests by Groups

\begin{tabular}{|c|c|c|c|c|c|c|c|c|}
\hline \multirow[b]{2}{*}{ Measure } & \multicolumn{2}{|c|}{ Group $-2 L(n=48)$} & \multicolumn{2}{|c|}{ Group $-4 L F(n=30)$} & \multicolumn{2}{|c|}{ Group-4LI $(n=37)$} & \multicolumn{2}{|c|}{ Control Group $(n=35)$} \\
\hline & $\begin{array}{c}\text { Pre } \\
M(S D)\end{array}$ & $\begin{array}{c}\text { Post } \\
M(S D)\end{array}$ & $\begin{array}{c}\text { Pre } \\
M(S D)\end{array}$ & $\begin{array}{c}\text { Post } \\
M(S D)\end{array}$ & $\begin{array}{c}\text { Pre } \\
M(S D)\end{array}$ & $\begin{array}{c}\text { Post } \\
M(S D)\end{array}$ & $\begin{array}{c}\text { Pre } \\
M(S D)\end{array}$ & $\begin{array}{c}\text { Post } \\
M(S D)\end{array}$ \\
\hline 2L-Syl & $97.4(3.3)$ & $97.6(4.4)$ & $98.1(2.7)$ & $97.0(3.5)$ & $97.3(4.0)$ & $97.0(4.5)$ & $96.5(5.2)$ & $97.0(5.1)$ \\
\hline 4LF-Syl & $92.9(8.6)$ & $95.5(5.2)$ & $95.0(5.7)$ & $98.2(3.6)$ & $94.4(5.7)$ & $95.2(5.7)$ & $94.4(5.9)$ & $95.0(5.3)$ \\
\hline 4LI-Syl & $90.5(8.1)$ & $92.1(7.4)$ & $92.7(7.5)$ & $93.2(7.6)$ & $90.3(8.0)$ & $95.0(5.6)$ & $90.0(9.5)$ & $91.7(10.7)$ \\
\hline 2L-Psw & $87.0(8.8)$ & $88.8(9.0)$ & $87.4(7.5)$ & $89.0(11.1)$ & $86.9(11.7)$ & $88.7(11.0)$ & $84.7(11.3)$ & $85.6(11.4)$ \\
\hline 4LF-Psw & $85.4(10.6)$ & $87.1(10.5)$ & $85.6(14.6)$ & $90.6(9.1)$ & $86.3(11.8)$ & $86.2(13.2)$ & $83.3(13.7)$ & $86.6(12.9)$ \\
\hline 4LI-Psw & $78.6(12.9)$ & $81.0(12.3)$ & $78.1(13.7)$ & $85.8(10.2)$ & $81.6(12.3)$ & $87.8(9.6)$ & $78.6(14.3)$ & $84.4(14.1)$ \\
\hline Text (sec/word) & $86.3(9.7)$ & $88.5(7.2)$ & $89.5(7.1)$ & $91.3(5.5)$ & $89.1(7.5)$ & $90.9(5.5)$ & $89.0(6.6)$ & $92.1(4.3)$ \\
\hline
\end{tabular}

Note. Group-2L practiced two-letter syllables (2L-Syl), Group-4LF practiced four-letter frequent syllables (4LFSyl), and Group-4LI practiced four-letter infrequent syllables (4LI-Syl). Psw = pseudowords; 2L-Psw are pseudowords, including trained two-letter syllables, and so on.

an outcome score. The assessment sessions were recorded (via a recording application integrated into the computerized training program) and stored online on a secure server. An advanced psychology student coded the completion times of the tasks and the percentage of accurately read items (syllables in the syllable lists and words in pseudoword lists and the text), and then checked the correctness of the assessment procedure from the recordings. Training began immediately after the pretraining assessment. The posttraining assessment was conducted within 2 weeks of 
the final training session. The presentation order of the tasks was fixed: three syllable lists, three pseudoword lists, a text reading task, and finally a rapid naming task. To avoid a strong priming effect, two list reading tasks were always situated between the syllable list and the pseudoword list containing the same syllables (e.g., two other syllable lists between the 2L-syllable list and the list of pseudowords containing the 2L-syllables).

Syllables. Separate lists for each type (three) of trained syllables were constructed, each consisting of all (30) trained syllables. The lists were presented in the same order for all participants. The order of the syllables within a list differed in the pre- and posttraining tests.

Pseudowords. Three lists of two-syllable pseudowords were constructed, each containing all the practiced syllables of particular type and presented in a similar manner as the syllable lists. Because of orthographic legality restrictions, 22 of the practiced syllables were initial and eight were final syllables of pseudowords.

Control task: Text reading. Two informational 120-word texts on animals (see Huemer et al., 2010) were read aloud, one as part of the pretraining and the other as part of the posttraining test. Altogether, the practiced syllables composed less than $10 \%$ of the texts.

Rapid automatized naming. A "stimulus card" consisted of five letters (O, A, S, T, P) arranged in five rows by 10 columns. The stimuli were presented in pseudorandom order, yet no individual stimulus was immediately repeated (Ahonen, Tuovinen, \& Leppäsaari, 1999).

\section{Training}

Implementation. The training period consisted of 10 (5-10 $\mathrm{min})$ computer training sessions in a 2- to 3-week period, with three to five sessions per week. Thirty practice syllables were randomly repeated five times during each session, resulting in 50 repetitions per syllable during the training period. By means of a computer program (for a detailed description of the program, see Lyytinen, Erskine, Kujala, Ojanen, \& Richardson, 2009), a participant heard an auditory stimulus via headphones and then chose the corresponding syllable as quickly as possible from five written options on the computer screen. The child received feedback according to the speed of accurate responses. A new trial immediately followed each answer. Feedback comparing the child's recognition speed to his or her previous sessions was given by the program after each training session.

Training materials. Trained syllables consisted of two-letter syllables, as well as frequent and infrequent four-letter syllables (Table 3), with each of the three types of syllables including 30 items. Two-letter syllables were matched with frequent four-letter syllables, according to their frequency in newspaper text (Department of General Linguistics, University of Helsinki, and Research Institute for the Languages of Finland, 1996-1998). Altogether, frequent four-letter syllables composed $24 \%$ and infrequent four-letter syllables $0.06 \%$ of all occurrences of four-letter syllables in common texts. Four-letter frequent and infrequent syllables were matched according to their structure. None of the syllables had a semantic meaning.

During the intervention, as a control for the general effect of training and teacher attention, the control group practiced simple addition, subtraction, and multiplication tasks using the same computer program. Each participant heard a number and was asked to select a corresponding 
TABLE 3

Syllable Characteristics per Training Condition

\begin{tabular}{|c|c|c|c|c|}
\hline Condition & Length & Frequency & Structure (n) & Examples \\
\hline $2 \mathrm{~L}$ & 2 letters & $1.945 \%$ & $\begin{array}{l}\mathrm{VV}^{\mathrm{a}}(1) \\
\mathrm{CV}(16) \\
\mathrm{VC}(14)\end{array}$ & $\begin{array}{l}\text { äi } \\
\text { nu, re, sö } \\
\text { ak, ul, äs }\end{array}$ \\
\hline $4 \mathrm{LF}$ & 4 letters & $1.956 \%$ & $\begin{array}{l}\text { CVCC (3) } \\
\text { CVVC (15) } \\
\operatorname{CVVC}^{\mathrm{a}}(12)\end{array}$ & $\begin{array}{l}\text { kans, ment, vält } \\
\text { viik, keen, muus } \\
\text { muis, siel, jouk }\end{array}$ \\
\hline $4 \mathrm{LI}$ & 4 letters & $0.005 \%$ & $\begin{array}{l}\text { CVCC (3) } \\
\text { CVVC (15) } \\
\operatorname{CVVC}^{\mathrm{a}}(12)\end{array}$ & $\begin{array}{l}\text { tyrs, punt, hömp } \\
\text { kiik, leet, noon } \\
\text { sius, teip, mouh }\end{array}$ \\
\hline
\end{tabular}

Note. $2 \mathrm{~L}=$ two-letter syllables; $4 \mathrm{LF}=$ four-letter frequent syllables; $4 \mathrm{LI}=$ four-letter infrequent syllables; Frequency $=$ percentage comprised by the category of all syllables in a common text (Department of General Linguistics et al., 1996-1998); Structure = order of vowels (V) and consonants (C) within the syllable. Note that none of the syllables included digraphs.

apiphthong.

equation presented on the screen. Feedback was based on the accuracy of the answer; speed was not emphasized. After the posttraining test, teachers were encouraged to also use the reading training program of their choice with the control group children.

\section{RESULTS}

\section{Pretraining Measurements}

As children with very low reading accuracy were excluded and the accuracy measures were close to the upper limit in the pre- and posttest data of all groups (see Table 2), only reading speed was included in statistical analyses. Distributions of speed measurements were skewed and thus normalized using natural logarithmic transformations. This procedure did not change the pattern of the results; these were comparable between the original and the transformed data. Crosstabulation for gender (categorical) and analyses of variance for continuous pretraining measures (Table 1) revealed no differences between the groups (2L, 4LF, 4LI, and No training) in gender, $\chi^{2}(3)=1.45, p=.693$; age, $F(3,146)=1.38, p=.252$; naming speed, $F(3,146)=0.52, p$ $=.666$; or in any of the reading speed measurements: two-letter syllables, $F(3,146)=1.11$, $p=.346$; four-letter frequent syllables, $F(3,146)=1.38, p=.252$; four-letter infrequent syllables, $F(3,146)=0.65, p=.586$; pseudowords containing two-letter syllables, $F(3,146)=$ $1.50, p=.218$; pseudowords containing four-letter frequent syllables, $F(3,146)=0.60, p=$ .615 ; pseudowords containing four-letter infrequent syllables, $F(3,146)=1.33, p=.267$; and text reading, $F(3,146)=0.96, p=.413$. Finally, to explore the effect of syllable frequency, the reading speed of four-letter frequent and infrequent syllables was compared to each other over all groups at the beginning of the training. The results showed that the four-letter frequent syllables were read significantly faster than the four-letter infrequent syllables, $t(149)=11.58, p<.001$. 


\section{Reading Speed Regarding Trained Syllables}

To test the training effect, the reading times for syllable lists were analyzed using mixed-model analyses of variance (ANOVAs) in which the Training condition (2L, 4LF, and 4LI in contrast to No training) served as a between-subjects factor and Time (pretest and posttest) as a withinsubject factor. Completion time for the list of trained syllables was used as a dependent variable to measure the training effect. The descriptive statistics of reading speed measures are presented in Table 1.

Significant Training Condition $\times$ Time interactions were apparent when comparing the training groups with the control group (see Table 1), indicating greater gains in the training groups with respect to the speed of reading trained syllables: specifically, Group-2L in two-letter syllables, $F(1,81)=5.84, p=.018, \eta_{p}{ }^{2}=.067$; Group-4LF in four-letter frequent syllables, $F(1,63)=11.83, p=.001, \eta_{p}{ }^{2}=.158$; and Group-4LI in four-letter infrequent syllables, $F(1,70)=25.22, p<.001, \eta_{p}{ }^{2}=.265$. No significant Training Condition $\times$ Time interactions were apparent in regard to untrained syllables when comparing the training groups with the control group, indicating that the training effect was evident in trained but not in untrained syllables.

The interaction between the reading progress (time) and the Training condition was further examined by means of the Johnson-Neyman procedure (Aiken \& West, 1991; Johnson \& Neyman, 1936; Potthoff, 1964). With this method, significance regions for the interaction were defined, producing limits beyond which differences between the training group and the control group were significant. With this method we were able to define the part of the training group that differed from the control group. The results revealed that the difference between the Group-2L and the control group in favor of the training group was significant in practiced syllables only for the $25 \%$ of participants who had been assessed as the poorest readers (at the pretraining stage). The corresponding figures for Group-4LF and Group-4LI were $77 \%$ and $73 \%$, respectively.

\section{Item-Specific and Transfer Effects}

Syllables. To test item-specificity at syllable level, development between pretest and posttest (Time) of the three training groups $(2 \mathrm{~L}, 4 \mathrm{LF}$, and $4 \mathrm{LI})$ was compared in all syllable types (Table 1). For two-letter syllables, the differences between Group-2L and the other training groups were not straightforward. The only comparison approaching significance was between Group-2L and Group-4LI, where $F(1,83)=3.59, p=.062, \eta_{p}{ }^{2}=.041$. In terms of the development of reading speed of four-letter frequent syllables, Group-4LF outperformed the two other groups: Group-4LF versus Group-2L, $F(1,76)=9.86, p=.002, \eta_{p}{ }^{2}=.115$, and Group-4LF versus Group-4LI, $F(1,65)=8.54, p=005, \eta_{p}{ }^{2}=.116$. Similar results were obtained regarding four-letter infrequent syllables in comparisons between Group-4LI and the other groups: Group4LI versus Group-2L, $F(1,83)=27.62, p<.001, \eta_{p}{ }^{2}=.250$, and Group-4LI versus Group-4LF, $F(1,65)=15.16, p<.001, \eta_{p}{ }^{2}=.189$. In sum, all training groups outperformed the control group with regard to the practiced syllables. With respect to long syllables, the training groups also differed from each other so that each training group outperformed the other groups in the trained syllables. 
Pseudowords. To explore a transfer effect to larger orthographic units, the list completion times for the pseudowords containing trained syllables (Table 1) were analyzed using the mixed-model ANOVAs in which the Training condition $(2 \mathrm{~L}, 4 \mathrm{LF}$, and $4 \mathrm{LI}$ in contrast to No training) served as a between-subjects factor and Time (pretest and posttest) as a within-subject factor. Although a trend indicated that the trained groups had a greater increase in speed in reading pseudowords than the control group in long syllables-Group-4F versus control group, $F(1,63)=2.04, p=.158, \eta_{p}{ }^{2}=.031$-this was shown statistically significant only with pseudowords containing four-letter infrequent syllables: Group-4LI versus control group, $F(1$, $70)=4.68, p=.034, \eta_{p}{ }^{2}=.063$, and Group-4LI versus Group-4LF, $F(1,65)=4.42, p=.039$, $\eta_{p}^{2}=.064$.

General reading speed. To explore the effects of training on the reading speed of the text including only few practiced syllables (Table 1), the development (pretest to posttest) of text reading speed was compared between each group ( $2 \mathrm{~L}, 4 \mathrm{LF}, 4 \mathrm{LI}$, and control) with mixed-model ANOVA. No differences were observed between the groups, $F(3,146)=0.98, p=.407, \eta_{p}{ }^{2}=$ .02 , indicating comparable development between the control and training groups.

\section{Initial Reading Speed and RAN}

The connections of initial reading speed (i.e., combined reading time for pseudowords and text in the pretraining test) and RAN with gains in syllable reading speed were analyzed separately in each training group using a linear regression model (Table 4). Distributions of the variables were positively skewed (i.e., skewness differed from zero on .01 significance level; Tabachnick \& Fidell, 2007) and thus normalized using natural logarithmic or square root transformation. Independent variables (RAN and initial reading speed) were first entered into analysis separately and then together (enter method) to measure their independent and shared variance in explaining the gains in reading speed (the training effect). RAN was positively related to the initial reading speed $(.52<r<.66)$ but was not associated with the training effect. Slow initial reading speed

TABLE 4

Regression Analyses Predicting Gains in Reading Speed of Syllables: Unique and Shared Variance for Rapid Automatized Naming and Initial Reading Speed

\begin{tabular}{|c|c|c|c|c|c|c|}
\hline \multirow[b]{2}{*}{ Gain Syllables } & \multicolumn{2}{|c|}{ Group $-2 L(\mathrm{n}=48)$} & \multicolumn{2}{|c|}{ Group- $4 L F(\mathrm{n}=30)$} & \multicolumn{2}{|c|}{ Group $-4 L I(\mathrm{n}=37)$} \\
\hline & $\beta$ & $R^{2}$ & $\beta$ & $R^{2}$ & $\beta$ & $R^{2}$ \\
\hline Model 1: RAN & -.080 & .006 & -.278 & .077 & .052 & .003 \\
\hline Model 2: IR & $-.365^{*}$ & .133 & -.177 & .031 & .018 & .000 \\
\hline Model 3: RAN and IR & $.162^{\mathrm{a}} /-.451^{\mathrm{b}, *}$ & .152 & $-.294^{\mathrm{a}} / .023^{\mathrm{b}}$ & .078 & $.062^{\mathrm{a}} / .017^{\mathrm{b}}$ & .003 \\
\hline
\end{tabular}

Note. Group-2L practiced two-letter syllables, Group-4LF practiced four-letter frequent syllables, and Group-4LI practiced four-letter infrequent syllables. Gain syllables = gain in reading speed of practiced syllables from pre- to posttraining test; RAN = rapid automatized naming of letters; IR = initial reading time for pseudowords and text (i.e., prior to intervention).

a Standardized Beta coefficient for RAN.

${ }^{\mathrm{b}}$ Standardized Beta coefficient for IR.

${ }^{*} p<.05 .{ }^{* *} p<.01 .{ }^{* * *} p<.001$. 
significantly predicted the better training effect for a group training two-letter syllables (Group2L) but not for the other training groups. Even though the independent variables were correlated, multicollinearity was not present: The tolerance coefficients were $0.714,0.538$, and 0.678 (i.e., clearly greater than a common border value 0.2 ) in analyses for gains in Group-2L, Group-4LF, and Group-4LI, respectively.

\section{DISCUSSION}

The aim of this study was to explore the effects of training and transfer of computerized syllable training on reading speed with regard to various types of syllables with poor readers in second and third grades, as well as to investigate the influence of initial reading speed and RAN on the training effect among these children. The results from a transparent language with a clear syllable structure (Finnish) reveal that the speed of reading trained syllables increased across all of the three training groups compared to the control group. The training effect was most pronounced for long infrequent syllables and least for short syllables. As expected, the effects of training did not transfer to other types of syllables or to text including only few practiced syllables. However, the expected transfer to larger units that included practiced items was less pronounced than in previous studies (Huemer et al., 2010). RAN predicted the initial reading speed but had no connection to the effect of training. Initial reading speed only predicted increases in the reading speed of short syllables.

The results showed that after repeated identification of syllables, all three training groups had more increases in syllable reading speed than the control group. This effect was evident already after a brief training (amounting to $1-2 \mathrm{hr}$ of practice), indicating that computer-based syllable recognition may be a promising tool for increasing the reading speed of practiced items for slow readers soon after the first school year in an orthographically transparent language.

The results confirmed our set of hypotheses concerning the frequency effect of syllables. First, frequent syllables were initially read faster than similar but infrequent syllables. This supports the hypothesis of there being a facilitating effect of syllable frequency on reading speed (Perea $\&$ Carreiras, 1998). Second, slower initial reading speed left more room for improvement, and hence the training effect was more pronounced for infrequent syllables $\left(\eta_{p}{ }^{2}=.265\right)$ than for frequent syllables $\left(\eta_{p}{ }^{2}=.158\right)$. This result also supports the claim that the greatest gains in repeated reading can be expected during the first exposures to practiced items, as three or four repetitions have been reported to be sufficient in most cases for both typical and poor readers (Meyer \& Felton, 1999), whereas the speed and accuracy of reading seem to reach their maximum after six repetitions (Lemoine et al., 1993). However, one should note that a greater amount of repetition may promote the retention and generalization of the training effects (Lemoine et al., 1993), especially in the case of dyslexia (Reitsma, 1983; Thaler et al., 2004). In sum, the training effect per se was stronger for infrequent syllables, compared to more frequent syllables, most likely due to less previous exposure. However, as we also found a significant training effect with more frequent items, we can expect that their effects on general reading may be even greater, as very few of the most frequent syllables comprise a substantial amount of the text (in Finnish, the 50 most frequent syllables comprise more than $50 \%$ of the text). That said, one should note that these frequent items may be already automatized due to prior exposure, and for this reason, additional training may not cause any significant gain in reading speed for poor readers in Grades 
2 and 3 who have already passed the first stages of reading development. Therefore, the selection of trained units should be planned carefully to promote an increase in both item-specific reading speed and a transfer to general reading.

In a comparison between short and long syllables, matched according to their frequency, the expected trend for longer syllables showing a greater training effect was confirmed $\left(\eta_{p}{ }^{2}=.158\right.$ for long and $\eta_{p}{ }^{2}=.067$ for short syllables). In addition, for two-letter syllables, the difference in gains between the training group and the control group was evident only in the poorest quarter of the sample; for four-letter syllables, the difference was evident for three fourths of the training group. This suggests that two-letter syllables were already automatized in most of the second and third graders in our sample. Therefore, further practice of two-letter syllables only helped the extremely slow readers. The increase of speed in reading long syllables probably indicates both automatization and a shift from serial letter-by-letter processing to a more holistic strategy of recognizing the syllable as a unit, which is in accord with the hypothesis of the self-teaching mechanism (Share, 1995). This finding is similar to studies that report a decreased length effect after practice (e.g., Maloney et al., 2009). Maloney et al. suggested that this effect reflects not the strengthening of grapheme-phoneme associations but rather a repetition-induced use of wholeitem print-to-sound associations. Therefore, the syllable-length effect is due to another, more effective parallel strategy for reading.

In terms of generalization, the training effect did not transfer to untrained Finnish syllables or to text that did not contain a large amount of practice items among the sample of poor readers in Grades 2 and 3. Our results are in line with previous results which show that the effects of fluency training are item specific (Berends \& Reitsma, 2006; Lemoine et al., 1993; Marinus et al., 2012; Thaler et al., 2004). However, in an earlier study examining repetitive syllable training, a transfer effect to larger units was demonstrated with long infrequent syllables (Huemer et al., 2010). Although in our study we also found a trend toward generalization to larger units above the practiced level (pseudowords containing practiced syllables), the effect was significant only with respect to infrequent syllables and the effect sizes were considerably lower than in the earlier study. We discuss the possible explanations later.

Finally, the connection of initial reading speed and RAN to the training effect was explored. As expected, RAN was correlated with initial reading speed in line with previous studies that have shown the connection between slow naming and slow reading (Holopainen et al., 2001; Lervåg \& Hulme, 2009; Savage \& Frederickson, 2005). Contrary to studies in which slow naming hindered the results of reading intervention (Compton, 2000; Stage et al., 2003), but in accord with the studies by Berends and Reitsma (2006) and Levy et al. (1997), RAN showed no direct influence on the training effect when initial reading speed was accounted for.

Initial reading speed was associated with progress in reading speed for short but not long syllables in Finnish. Analysis revealed that the participants who gained the most from the training were the slowest of the poor readers. This is rather easy to understand in light of the results presented before: That is, most participants had increases in reading speed with respect to long syllables (regardless of initial reading speed), but with respect to short syllables, the increases were evident only among the slowest readers. One of the most appealing explanations for this is very simple: Even though there is no absolute ceiling for reading speed, development in speed reaches its "asymptote" sooner or later (Breznitz, 2006). The slowest readers have the most room for improvement, as the faster readers may already have been close to this asymptote at the beginning of the experiment. This most probably explains the differences in development between 
the limits of the range of initial reading speed. Given the lesser effects of training and that the initial reading speed of the fastest readers reached the average of typical readers in general reading speed (compared to JLD data; Torppa et al., 2010), this explanation seems plausible for this sample. However, this does not mean there is no advantage of training even for the faster part of the group, as there was still a variation in gains with these children. For long items, for example, the majority $(77 \%$ and $73 \%$ of the second and third graders practicing frequent and infrequent long syllables, respectively) of all the poor readers in our sample improved, not just those at the lowest level. It is encouraging to find that the poorest readers were actually not the most resistant to training, as has been previously reported (Berninger et al., 2002). Repeated syllable training seems to benefit children learning to read a transparent language with a clearly defined syllable structure.

Although the results of this study were promising with regard to gains in syllable reading speed, the training effect $\left(\eta_{p}{ }^{2}=.27\right)$ was weaker than that seen in an earlier study assessing the effects of repeated reading practice with infrequent syllables $\left(\eta_{p}{ }^{2}=.60-.63\right.$; Huemer et al., 2010). There are several possible explanations for the difference in results. First, training specific syllables using silent recognition may be less effective than reading them aloud. One explanation could be that active naming requires higher engagement and attention, compared to more passive recognition (Thaler et al., 2004). This notion is supported by the findings of Hintikka et al. (2008), where training methods similar to ours produced a comparable effect size $\left(\eta_{p}{ }^{2}=.29\right)$ in consonant cluster recognition in German (Hintikka et al., 2008). This possible disadvantage of recognition tasks could be compensated for by prompting the reader for overt vocalization of responses, or by simply increasing the amount of practice. The effectiveness of different training methodssuch as oral reading, silent reading and silent recognition-should also be explicitly compared, especially because consensus on the superiority of any one method has not been reached (Berends \& Reitsma, 2007; de Jong \& Share, 2007; Share, 2008).

Another explanation for the weaker training effect in this study is related to the assessment. The outcome measurements used by Huemer et al. (2010) were similar to the training method they used, as both involved reading aloud. However, in our study (as well as the one done by Hintikka et al., 2008), recognition tasks utilizing a computer were used in training sessions whereas test measures were based on reading aloud. Accordingly, transfer from recognition to reading aloud was required, something that may have affected the observed effects of training and made comparisons to previous studies more complicated. This could also explain the observed weaker transfer effect to pseudowords, compared to Huemer et al. (2010). A "double-transfer" was required in our study (i.e., from syllables to pseudowords and also from recognition to reading aloud). In further studies, the transfer effect should be measured in more detail by assessing both silent recognition and reading aloud. Thus, a challenge for future research will be to develop tasks that reliably measure the silent recognition speed of sublexical items.

A limitation of the present study is the absence of standardized measurements for reading speed and IQ, as they are not available for teachers. Accordingly, the heterogeneity of the sample in regard to initial reading skills and IQ could not be fully explored, nor could a comparison between poor and typical readers be made in this study. However, the background information provided by parents and teachers was used when excluding children representing the extremes of reading skill levels and in alleviating the bias caused by heterogeneity. Also, a comparison with the well-documented Finnish data of typical and dyslexic readers (Torppa et al., 2010) verified the positioning of the sample in terms of the distribution of reading performance. 
In further studies, it would be worth exploring if the observed training effects are specifically related to syllable-level processing or if they could also be found with other sublexical units that are common in the orthography (e.g., suffixes, common letter combinations). Our present study and the study by Huemer at al. (2010) addressed syllable training directly without promoting generalization per se. In future studies, the factor of transfer to word and text levels should be addressed within the framework of syllable training, perhaps moving in the direction of the subsyllabic method of text reading (Tressoldi et al., 2007). We also acknowledge that syllable training on its own is not very motivating, and in practical applications of this approach, multifaceted methods should be used to promote both motivation and transfer. Because the ultimate goal of fluent reading is comprehension, we will need to measure the effects of fluency training in terms of not only reading speed but also reading comprehension.

In summary, this study has shown the promising effects of syllable training for poor readers in Grades 2 and 3 in a transparent language with a clear syllable structure (Finnish), indicating item-specific associations between print and sound during independent reading practice, even with respect to larger sublexical items than letters. In the future, more attention needs to be paid to finding effective means of supporting transfer to everyday reading contexts. Slow naming and slow reading speed did not seem to hinder the training effects, which is a promising result for educators working with poor readers.

\section{REFERENCES}

Ahonen, T., Tuovinen, S., \& Leppäsaari, T. (1999). Nopean sarjallisen nimeämisen testi $[$ The test of rapid serial naming]. Jyväskylä, Finland: Niilo Mäki Instituutti \& Haukkarannan koulu.

Aiken, L. S., \& West, S. G. (1991). Multiple regression: Testing and interpreting interactions. Newbury Park, CA: Sage.

Ans, B., Carbonnel, S., \& Valdois, S. (1998). A connectionist multiple-trace memory model for polysyllabic word reading. Psychological Review, 105, 678-723. doi:10.1037//0033-295X.105.4.678-723

Aro, M. (2006). Learning to read: The effect of orthography. In R. M. Joshi \& P. G. Aaron (Ed.), Handbook of orthography and literacy (pp. 531-550). Mahwah, NJ: Erlbaum.

Berends, I., \& Reitsma, P. (2006). Remediation of fluency: Word specific or generalised training effects? Reading and Writing: An Interdisciplinary Journal, 19, 221-234. doi:10.1007/s11145-005-5259-3

Berends, I., \& Reitsma, P. (2007). Orthographic analysis of words during fluency training promotes reading of new similar words. Journal for Research in Reading, 30, 129-139. doi:10.1111/j.1467-9817.2006.00324.x

Berninger, V. W., Abbott, R. D., Vermeulen, K., Ogier, S., Brooksher, R., Zook, D., \& Lemos, Z. (2002). Comparison of faster \& slower responders to early intervention in reading: Differentiating features of their language profiles. Learning Disability Quarterly, 25, 59-76. doi:10.2307/1511191

Bowers, P. G. (1993). Text reading and rereading: Determinants of fluency beyond word recognition. Journal of Reading Behavior, 25, 133-153. Retrieved from doi:10.1080/10862969309547807

Breznitz, Z. (2006). Fluency in reading: Synchronization of processes. Mahwah, NJ: Erlbaum.

Burani, C., Marcolini, S., De Luca, M., \& Zoccolotti, P. (2008). Morpheme-based reading aloud: Evidence from dyslexic and skilled Italian readers. Cognition, 108, 243-262. doi:10.1016/j.cognition.2007.12.010

Carreiras, M., \& Perea, M. (2004). Naming pseudowords in Spanish: Effects of syllable frequency. Brain \& Language, 90, 393-400. doi:10.1016/j.bandl.2003.12.003

Chard, D. J., Vaughn, S., \& Tyler, B.-J. (2002). A synthesis of research on effective interventions for building reading fluency with elementary students with learning disabilities. Journal of Learning Disabilities, 35, 386-406. doi:10.1177/00222194020350050101

Compton, D. L. (2000). Modeling the growth of decoding skills in first-grade children. Scientific Studies of Reading, 4 , 219-259. doi:10.1207/S1532799XSSR0403_3 
Conrad, M., Stenneken, P., \& Jacobs, A. M. (2006). Associated or dissociated effects of syllable frequency in lexical decision and naming. Psychonomic Bulletin \& Review, 13, 339-345. doi:10.3758/BF03193854

De Jong, P. F., \& Share, D. L. (2007). Orthographic learning during oral and silent reading. Scientific Studies of Reading, 11, 55-71. doi:10.1080/10888430709336634

De Jong, P. F., \& van der Leij, A. (2003). Developmental changes in the manifestation of a phonological deficit in dyslexic children learning to read a regular orthography. Journal of Educational Psychology, 95, 22-40. doi:10.1037/00220663.95.1.22

Department of General Linguistics, University of Helsinki, and Research Institute for the Languages of Finland. (1996-1998). PAROLE corpus of the Finnish language [Data file]. Retrieved from http://www.csc.fi/english/research/ software/parole-fi/

Duncan, L. G., Colé, P., Seymour, P. H. K., \& Magnan, A. (2006). Differing sequences of metaphonological development in French and English. Journal of Child Language, 33, 369-399. doi:10.1017/S030500090600732X

Ecalle, J., \& Magnan, A. (2007). Development of phonological skills and learning to read in French. European Journal of Psychology of Education, 22, 153-167. doi:10.1007/BF03173519

Ecalle, J., Magnan, A., \& Calmus, C. (2009). Lasting effects on literacy skills with a computer-assisted learning using syllabic units in low-progress readers. Computers \& Education, 52, 554-561. doi:10.1016/j.compedu.2008.10.010

Escribano, C. (2007). Evaluation of the double-deficit hypothesis subtype classification of readers in Spanish. Journal of Learning Disabilities, 40, 319-330. doi:10.1177/00222194070400040301

Frost, R., Katz, L., \& Bentin, S. (1987). Strategies for visual word recognition and orthographical depth: A multilingual comparison. Journal of Experimental Psychology: Human Perception and Performance, 13, 104-115. doi:10.1037//0096-1523.13.1.104

Hintikka, S., Landerl, K., Aro, M., \& Lyytinen, H. (2008). Training reading fluency: Is it important to practice reading aloud and is generalization possible? Annals of Dyslexia 58, 59-79. doi:10.1007/s11881-008-0012-7

Holopainen, L., Ahonen, T., \& Lyytinen, H. (2001). Predicting delay in reading achievement in a highly transparent language. Journal of Learning Disabilities, 34, 401-413. doi:10.1177/002221940103400502

Huemer, S. (2009). Training reading skills: Towards fluency (Unpublished doctoral thesis). University of Jyväskylä, Jyväskylä, Finland. Retrieved from https://jyx.jyu.fi/dspace/bitstream/handle/123456789/20133/9789513935863.pdf

Huemer, S., Aro, M., Landerl, K., \& Lyytinen, H. (2010). Repeated reading of syllables among Finnish-speaking children with poor reading skills. Scientific Studies of Reading, 14, 317-340. doi:10.1080/10888430903150659

Huemer, S., Landerl, K., Aro, M., \& Lyytinen, H. (2008). Training reading fluency among poor readers of German: Many ways to the goal? Annals of Dyslexia, 58, 115-137. doi:10.1007/s11881-008-0017-2

Irausquin, R., Drent, J., \& Verhoeven, L. (2005). Benefits of computer-presented speed training for poor readers. Annals of Dyslexia, 55, 246-265. doi:10.1007/s11881-005-0013-8

Johnson, P. O., \& Neyman, J. (1936). Tests of certain linear hypotheses and their application to some educational problems. Statistical Research Memoirs, 1, 57-93.

Kame'enui, E. J., \& Simmons, D. C. (2001). Introduction to this special issue: The DNA of reading fluency. Scientific Studies of Reading, 5, 203-210. doi:10.1207/S1532799XSSR0503_1

Karlsson, F. (2008). Finnish: An essential grammar (2nd ed.). London, UK: Routledge.

Kirby, J. R., Georgiou, G. K., Martinussen, R., \& Parrila, R. (2010). Naming speed and reading: From prediction to instruction. Reading Research Quarterly, 45, 341-362. doi:10.1598/RRQ.45.3.4

Klauda, S. L., \& Guthrie, J. T. (2008). Relationships of three components of reading fluency to reading comprehension. Journal of Educational Psychology, 100, 310-321. doi:10.1037/0022-0663.100.2.310

Kuhn, M. R., \& Stahl, S. (2003). Fluency: A review of developmental and remedial practices. The Journal of Educational Psychology, 95, 3-21. doi:10.1037/0022-0663.95.1.3

LaBerge, D., \& Samuels, S. J. (1974). Toward a theory of automatic information processing in reading. Cognitive Psychology, 6, 293-323. doi:10.1016/0010-0285(74)90015-2

Landerl, K., \& Wimmer, H. (2008). Development of word reading fluency and spelling in a consistent orthography: An 8-year follow-up. Journal of Educational Psychology, 100, 150-161. doi:10.1037/0022-0663.100.1.150

Leinonen, S., Müller, K., Leppänen, P. H. T., Aro, M., Ahonen, T., \& Lyytinen, H. (2001). Heterogeneity in adult dyslexic readers: Relating processing skills to the speed and accuracy of oral text reading. Reading and Writing: An Interdisciplinary Journal, 14, 265-296. doi:10.1023/A:1011117620895

Lemoine, H., Levy, B. A., \& Hutchinson, A. (1993). Increasing the naming speed of poor readers: Representations formed across repetitions. Journal of Experimental Child Psychology, 55, 297-328. doi:10.1006/jecp.1993.1018 
Lervåg, A., \& Hulme, C. (2009). Rapid naming (RAN) taps a basic constraint on the development of early reading fluency. Psychological Science, 20, 1040-1048. doi:10.1111/j.1467-9280.2009.02405.x

Levy, B. A., Abello, B., \& Lysynchuk, L. (1997). Transfer from word training to reading in context: Gains in reading fluency and comprehension. Learning Disability Quarterly, 20, 173-188. doi:10.2307/1511307

Levy, B. A., Bourassa, D. C., \& Horn, C. (1999). Fast and slow namers: Benefits of segmentation and whole word training. Journal of Experimental Child Psychology, 73, 115-138. doi:10.1006/jecp.1999.2497

Lyytinen, H., Erskine, J., Kujala, J., Ojanen, E., \& Richardson, U. (2009). In search of a science-based application: A learning tool for reading acquisition. Scandinavian Journal of Psychology, 50, 668-675. doi:10.1111/j. 14679450.2009. 00791

Maloney, E., Risko, E. F., O’Malley, S., \& Besner, D. (2009). Tracking the transition from sublexical to lexical processing: On the creation of orthographic and phonological lexical representations. The Quarterly Journal of Experimental Psychology, 62, 858-867. doi:10.1080/17470210802578385

Marinus, E., de Jong, P., \& van der Leij, A. (2012). Increasing word-reading speed in poor readers: No additional benefits of explicit letter-cluster training. Scientific Studies of Reading, 16, 166-185. doi:10.1080/10888438.2011.554471

Meyer, M. S., \& Felton, R. H., (1999). Repeated reading to enhance fluency: Old approaches and new directions. Annals of Dyslexia, 49, 283-306. doi:10.1007/s11881-999-0027-8

National Institute of Child Health and Human Development. (2000). Report of the National Reading Panel. Teaching children to read: An evidence-based assessment of the scientific research literature on reading and its implications for reading instruction. Washington, DC: Government Printing Office.

Niemi, J., Laine, M., \& Tuominen, J. (1994). Cognitive morphology in Finnish: Foundations of a new model. Language and Cognitive Processes, 9, 423-446. doi:10.1080/01690969408402126

Norton, E. S., \& Wolf, M. (2012). Rapid automatized naming (RAN) and reading fluency: Implications for understanding and treatment of reading disabilities. Annual Review of Psychology, 63, 427-452. doi: 10.1146/annurev-psych120710-100431

Pagliuca, G., \& Monaghan, P. (2010). Discovering large grain sizes in a transparent orthography: Insights from a connectionist model of Italian word naming. European Journal of Cognitive Psychology, 22, 813-835. doi: $10.1080 / 09541440903172158$

Paulesu, E. (2006). On the advantage of 'shallow' orthographies: Number and grain size of the orthographic units or consistency per se? Developmental Science, 9, 443-444. doi:10.1111/j.1467-7687.2006.00525.x

Perea, M., \& Carreiras, M. (1998). Effects of syllable frequency and syllable neighbourhood frequency in visual word recognition. Journal of Experimental Psychology. Human Perception and Performance, 24, $134-144$. doi:10.1037/0096-1523.24.1.134

Perfetti, C. A. (1985). Reading ability. London, UK: Oxford University Press.

Potthoff, R. F. (1964). On the Johnson-Neyman technique and some extensions thereof. Psychometrika, 29, $241-256$. doi: $10.1007 /$ BF02289721

Reitsma, P. (1983). Printed word learning in beginning readers. Journal of Experimental Child Psychology, 75, 321-339. doi:10.1016/0022-0965(83)90036-X

Savage, R., \& Frederickson, N. (2005). Evidence of a highly specific relationship between rapid automatic naming of digits and text-reading speed. Brain and Language, 93, 152-159. doi:10.1016/j.bandl.2004.09.005

Seymor, P. H. K., Aro, M., \& Erskine, J. M. (2003). Foundation literacy acquisition in European orthographies. British Journal of Psychology, 94, 143-174. doi:10.1348/000712603321661859

Share, D. L. (1995). Phonological recoding and self-teaching: Sine qua non of reading acquisition. Cognition, 55, 151-218. doi:10.1016/0010-0277(94)00645-2

Share, D. L. (2008). On the Anglocentricities of current reading research and practice: The perils of overreliance on an “outlier" orthography. Psychological Bulletin, 134, 584-615. doi:10.1037/0033-2909.134.4.584

Stage, S. A., Abbott, R. D., Jenkins, J. R., \& Berninger, V. W. (2003). Predicting response to early instruction from verbal IQ, reading related language abilities, attention ratings, and verbal IQ-reading discrepancy. Journal of Learning Disabilities, 36, 24-33. doi:10.1177/00222194030360010401

Tabachnick, B. G., \& Fidell, L. S. (2007). Using multivariate statistics (5th ed.). Boston, MA: Pearson Education/Allyn and Bacon.

Thaler, V., Ebner, E. M., Wimmer, H., \& Landerl, K. (2004). Training reading fluency in dysfluent readers with high reading accuracy: Word specific effects but low transfer to untrained words. Annals of Dyslexia, 54, 89-113. doi:10.1007/s11881-004-0005-0 
Therrien, W. (2004). Fluency and comprehension gains as a result of repeated reading: A meta-analysis. Remedial and Special Education, 25, 252-261. doi:10.1177/07419325040250040801

Torppa, M., Lyytinen, P., Erskine, J., Eklund, K., \& Lyytinen, H. (2010). Language development, literacy skills, and predictive connections to reading in Finnish children with and without familial risk for dyslexia. Journal of Learning Disabilities, 43, 308-321. doi:10.1177/0022219410369096

Tressoldi, P. E., Vio, C., \& Iozzino, R. (2007). Efficacy of an intervention to improve fluency in children with developmental dyslexia in a regular orthography. Journal of Learning Disabilities, 40, 203-209. doi: $10.1177 / 00222194070400030201$

Wentink, H., Van Bon, W., \& Schreuder, R. (1997). Training of poor readers' phonological decoding skills: Evidence for syllable-bound processing. Reading and Writing: An Interdisciplinary Journal, 9, 163-192. doi:10.1023/A:1007921805360

Wimmer, H. (1993). Characteristics of developmental dyslexia in a regular writing system. Applied Psycholinguistics, 14, 1-33. doi:10.1017/S0142716400010122

Yap, R., \& van der Leij, A. (1993). Word processing in dyslexics: An automatic decoding deficit? Reading and Writing: An Interdisciplinary Journal, 5, 261-279. doi:10.1007/BF01027391

Ziegler, J., \& Goswami, U. (2005). Reading acquisition, developmental dyslexia, and skilled reading across languages: A psycholinguistic grain size theory. Psychological Bulletin, 131, 3-29. doi:10.1037/0033-2909.131.1.3

Zoccolotti, P., De Luca, M., Di Pace, E., Judica, A., Orlandi, M., \& Spinelli, D. (1999). Markers of developmental surface dyslexia in a language (Italian) with high grapheme-phoneme correspondence. Applied Psycholinguistics, 20, 191-216. doi:10.1017/S0142716499002027 